ROBSON LUIZ LIMA SANTOS

\title{
ANTI-SEMITISMO NA COMPANHIA DE JESUS
}

(1540 - 1593).

Tese Apresentada ao Curso de Pós-Graduação em História Social da Universidadede São Paulo, como Requisito Parcial para a Obtenção do Grau de Doutor.

Orientadora: Prof. ${ }^{a}$ Dr. ${ }^{a}$ Anita Waingort Novinsky.

São Paulo, Maio de 2007. 


\section{SUMÁRIO}

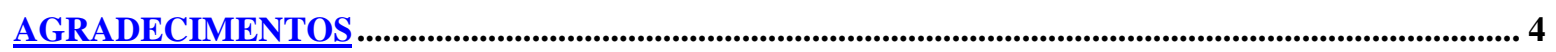

RESUMO

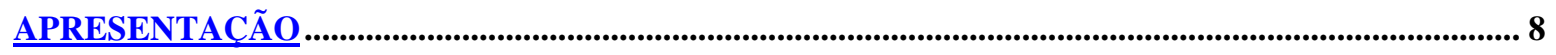

CAPÍTULO I. OS CRISTÃOS NOVOS NA FORMAČ̃̃O DA COMPANHIA DE JESUS..................... 14

OS ESTATUTOS DE LIMPEZA DE SANGUE ……………………….................................................. 14 A INTOLERÂNCIA CONTRA OS CONVERSOS E AS ADMISSÕES REALIZADAS PELA COMPANHIA 15

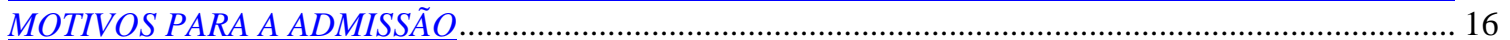

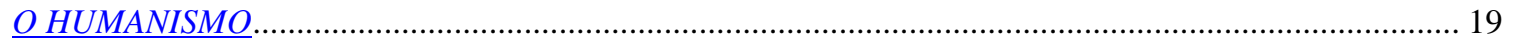

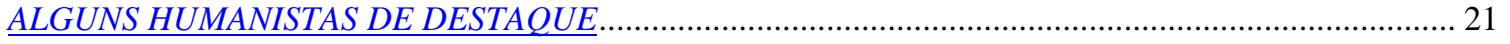

CAPÍTULO II. A COMPANHIA DE JESUS: SEUS IDEAIS E SUAS TRANSFORMACÕES ............. 27

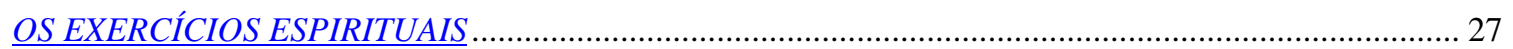

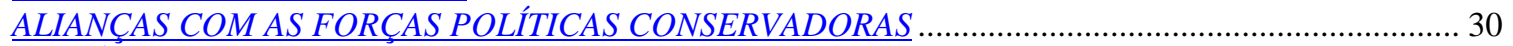

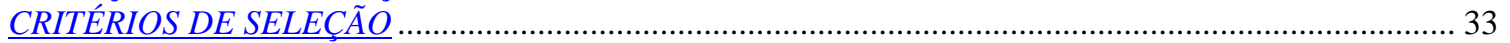

CAPÍTULO III. A PROBLEMÁTICA DOS CONVERSOS NA COMPANHIA DE JESUS DURANTE AS PRIMEIRAS DÉCADAS DE SEU FUNCIONAMENTO …..........................................................39

A EXCLUSÃO DOS CRISTÃOS NOVOS DO COLÉGIO DE COIMBRA ………..................................... 40

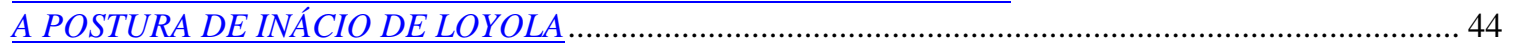

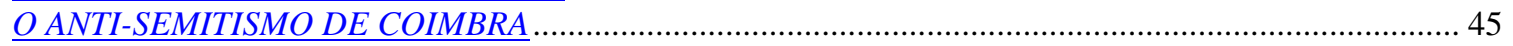

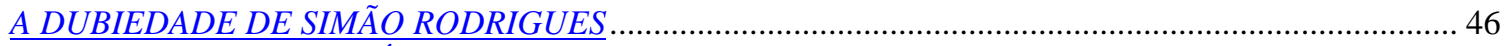

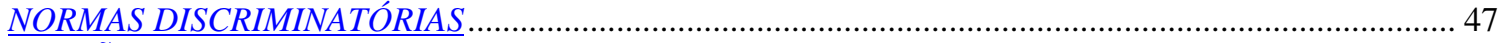

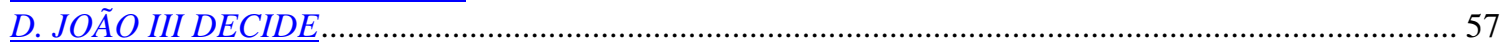

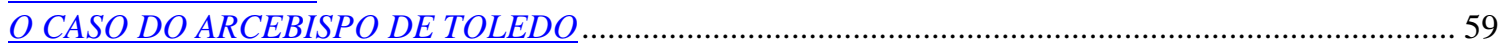

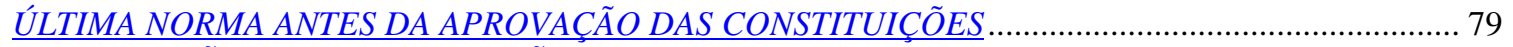

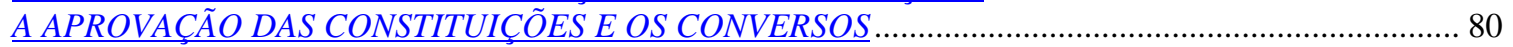

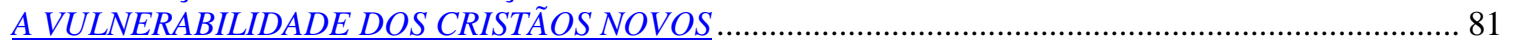

CAPÍTULO IV. JESUÍTAS DE ORIGEM JUDAICA NO ORIENTE........................................................ 83

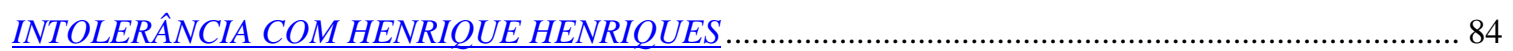

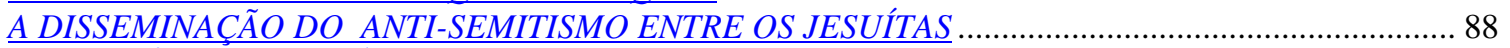

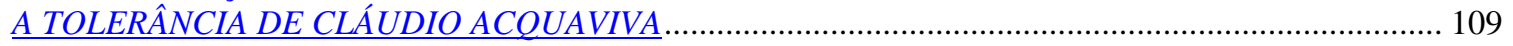

CAPÍTULO V. A COMPANHIA DE JESUS E O SEU PAPEL NA INSTALACC̃̃O DO TRIBUNAL DO SANTO OFÍCIO DA INQUISIĊÃO EM GOA ......................................................................................... 118

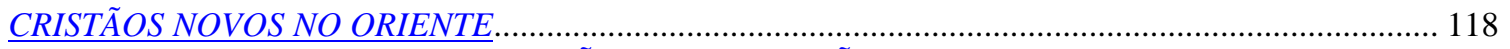

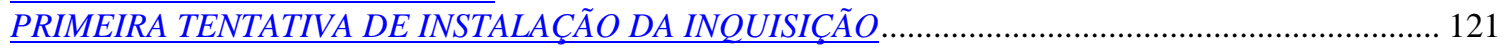

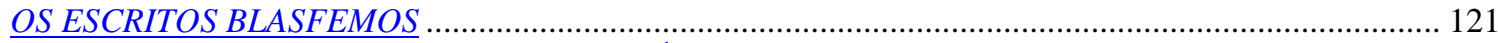

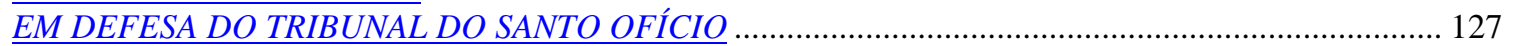

CHEGOU O MOMENTO DA INSTALAÇÃO DO TRIBUNAL INQUISITORIAL.................................... 130 
O PAPEL DA COMPANHIA DE JESUS E DA COROA PORTUGUESA NA INSTALAÇÃO DO

TRIBUNAL DO SANTO OFÍCIO EM GOA. 132

CAPÍTULO VI. A INQUISIÇÃO E A ATUAÇÃO DA COMPANHIA DE JESUS EM RELAÇÃO AOS CRISTÃOS NOVOS EM GOA, PERU E BRASIL ........................................................................................ 137

SERVIÇOS PRESTADOS À INQUISIÇÃO E PELOS JESUÍTAS E OS CONFLITOS DECORRENTES.. 137

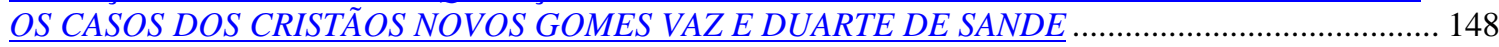

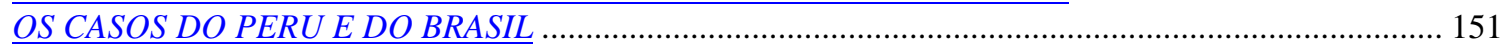

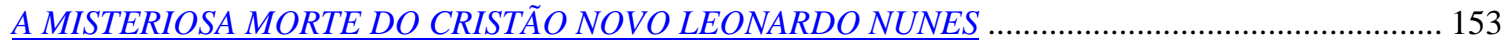

CAPÍTULO VII. A COMPANHIA DE JESUS, OS CRISTÃOS NOVOS E A INQUISIÇÃO EM

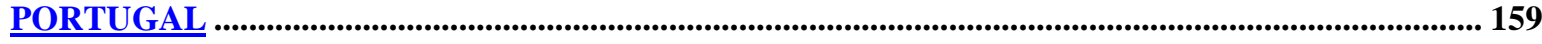

O PAPEL DE INÁCIO DE LOYOLA NA CONSOLIDAÇÃO DA INQUISIÇÃO PORTUGUESA. ............ 159

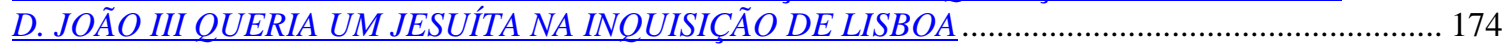

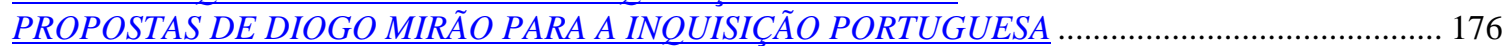
A DECISÃO DA COMPANHIA A RESPEITO DA PROPOSTA DO MONARCA ……............................... 177 D. HENRIQUE ESCOLHEU UM DOMINICANO PARA INQUISIDOR ............................................... 178 SERVIÇOS PRESTADOS PELA COMPANHIA DE JESUS À INQUISIÇÃO PORTUGUESA................... 180

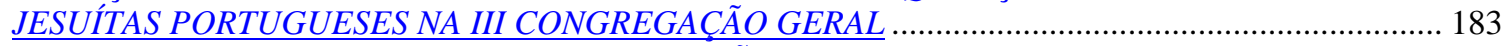

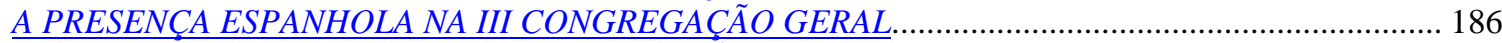

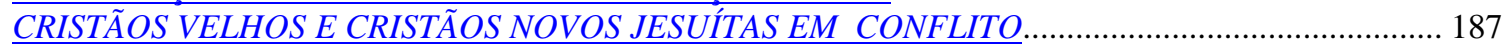

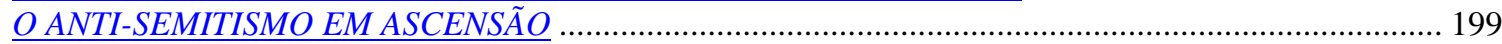

CAPÍTULO VIII. A COMPANHIA DE JESUS, OS CRISTÃOS NOVOS, A INQUISIÇÃO E A NOBREZA ESPANHOLAS ……............................................................................................................................... 201

A COMPANHIA DE JESUS E OTRIBUNAL DO SANTO OFÍCIODAINQUISIÇÃO NA ESPANHA........ 201

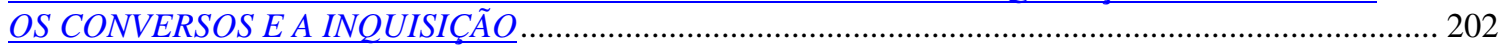

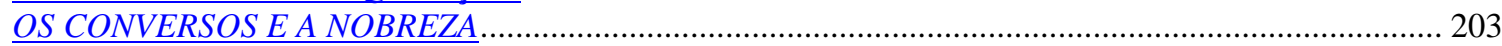

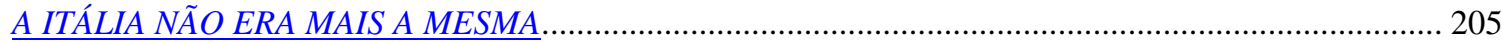
INTENSIFICAÇÃO DA PRESSÃO DA INQUISIÇÃO CONTRA OS CRISTÃOS NOVOS.......................... 205 DESINTELIGÊNCIAS ENTRE A COMPANHIA E A INQUISIÇÃO E A QUESTÃO DOS MEMORIAIS 206

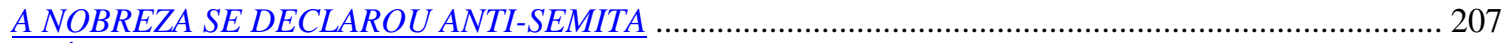

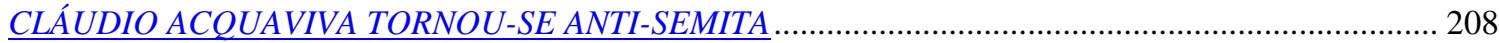
O ATAQUE DE ALONSO SANCHES CONTRA OS CRISTÃOS NOVOS E O CASO DO PADRE JOSÉ DE

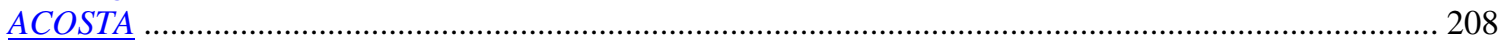

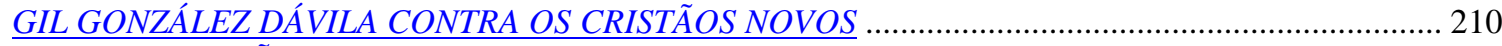
A CONGREGAÇÃO PROVINCIAL DE TOLEDO APROVOU O ESTATUTO DE LIMPEZA DE SANGUE

$\ldots$

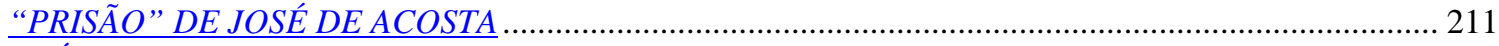

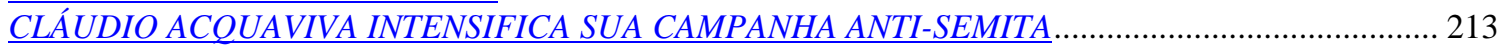

CAPÍTULO IX. OS “EXCLUÍDOS”. VENCERAM OS ANTI-SEMITAS .............................................. 216

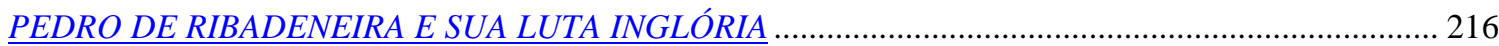

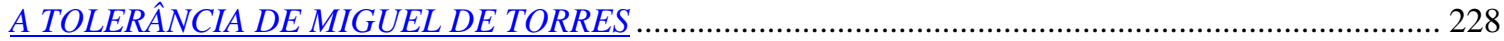

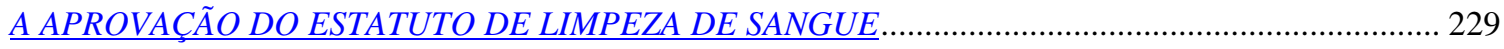

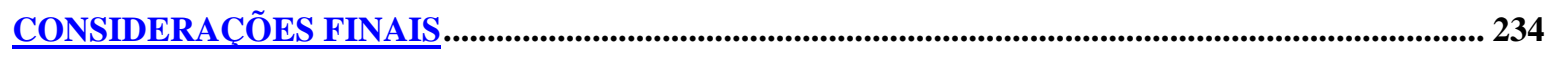

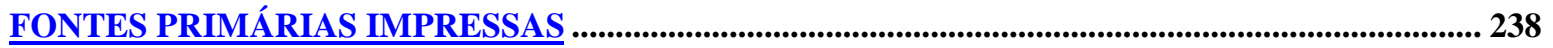

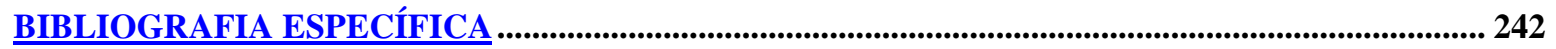

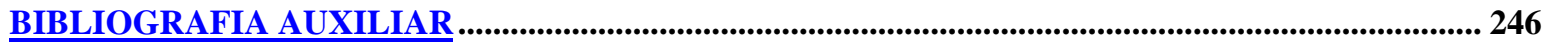

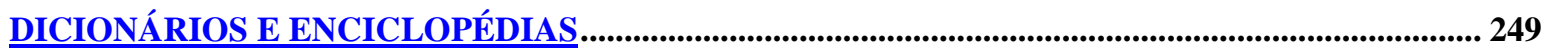




\section{AGRADECIMENTOS}

Agradeço à professora $\operatorname{Dr}^{\mathrm{a}}$ Anita Waingort Novinsky pela indicação do tema desta pesquisa, pelo incentivo em pleitear uma bolsa para pesquisar no exterior e pelo apoio dado na elaboração do projeto para a sua obtenção.

Sou grato à Coordenação de Aperfeiçoameto de Pessoal de Nível Superir - CAPES - pela concessão da Bolsa de Estudos do Programa de Doutorado no País com Estágio no Exterior.

A Milena Lima Santos Rocha, cujo apoio, em todos os sentidos, foi imprescindível para a realização desta tese.

Aos meus pais, falecidos, José Messias dos Santos e Maria da Conceição Lima Santos, e a toda minha família que apesar de tantas limitações, tornaram possível este trabalho.

Ao Doutor António Dias Farinha, que me acolheu em Lisboa com seu carinho e competência especiais.

Minha gratidão ao professor da Faculdade de Letras da Universidade de Lisboa, doutor Arnaldo Espírito Santo, pela tradução para o português dos documentos em latim. Agradeço às historiadoras da Revista Brotéria Ana Cristina e Ana Maria, pela amizade e diligência.

Meus agradecimentos aos padres jesuítas da Rivista Brotéria pela cordialidade e gentileza prestadas, especialmente ao Padre Hermínio Rico.

A todos os funcionários e funcionários das bibliotecas e arquivos visitados. Sou grato ainda a todos os colegas, especialmente a Lina Gorenstei, Benair Ribeiro, Marcelo Amaral, Paulo Valadares e Bruno Fleiter pelo apoio recebido. 


\section{RESUMO}

Esta pesquisa teve como objetivo demonstrar o anti-semitismo na Companhia de Jesus apontando suas causas e consequências.

Enumerei e analisei os motivos pelos quais a Ordem recebeu os cristãos novos em um contexto de crescente sentimento anti-semita. Evidencie o papel relevante desempenhado pelos cristãos novos na criação e no crescimento da Companhia de Jesus até no momento da aprovação do Estatuto de Limpeza de Sangue.

Analisei os conflitos que a Companhia de Jesus enfrentou devido ao recebimento dos conversos. Esta política de tolerância com os cristãos novos foi contestada, desde o início, tanto por jesuítas cristãos velhos, quanto pela nobreza, por membros influentes das coroas ibéricas e pelo Tribunal do Santo Ofício.

Com o transcorrer do tempo os anti-semitas foram ganhando força política. Os cristãos novos começaram a perder os cargos ocupados durante os primeiros anos da Companhia e o ingresso na Ordem foi se tornando cada vez mais dificultado e em alguns casos não eram recebidos antes mesmo da aprovação do Estatuto de Limpeza de Sangue.

Apesar das dificuldades enfrentadas, nos primeiros trinta anos da Companhia de Jesus foi possível receber os conversos. A Ordem sempre encontrava alguma forma de incorporá-los ao seu corpo de sacerdotes. Transferia os descriminados para lugares onde o anti-semitismo fosse menor ou mudava seus nomes. 
Entretanto, a intolerância foi se acirrando, os estigmas contra os judeus atingia cada vez mais intensamente os jesuítas cristãos novos. Os dirigentes da Companhia tentarem dar continuidade ao legado tolerante das primeiras gerações dos inacianos. Mas logo adotaram as práticas anti-semitas.

A Companhia de Jesus resolveu adotar o Estatuto de Limpeza de Sangue que impediu o ingresso dos conversos. Encerrou-se a etapa humanista dos inacianos. Fechou-se a porta da casa que acolheu e permitiu que muitos cristãos novos fizessem parte do rol dos expoentes jesuítas.

\section{ABSTRACT}

This research had as objective to show the anti-semitism in the Jesus Company pointing its causes and consequences.

I analysed and enumerated the reasons for which the Order received them in a context from increasing anti-semitic sense. Its has been showed the relevant role played by the new christians in the creation and growth of the Jesus Company even in the moment of approval of Statute of Clenness of Blood.

It had been analized that the Jesus of Company faced due to the act receiving of the converts. This politics of tolerance with the new christians was contested, since the beginning, both for old christian jesuits, and for the nobility, influential members of the Iberian Crowns and and for the Court of the Saint Profession

Along the time the anti-semitcs had been gaining political forces. The new christians had started to lose the ocuppied positions during the first years of the Company and the ingression in the Order was becoming more difficult through the time and in some cases they were not received even before the approval the Statute of Cleannses of Blood.

Although the faced difficultys in first years of the Company of Jesus were possible to receive the converts. The Order always found some way to incorporate 
them in its corps of priests. Transferred the acquitted ones for places where the antisemitism was lesser or changed its names.

However the intolerance was became inciting, the stigmas against the Jews reached every time more intensely the new christians jesuits. The leaders of the Company tryed to give continuity to the tolerance legacy of the first generations of ignacians. But they gad soon adopted the anti-semitics practices.

The Company of Jesus decided to adopt the Statute of Cleannses of Blood that obstructed the ingression of the converts. It was locked the humanistic stage of the ignatians, and it was closed the door of the house that received and allowed that many new christians were part of the roll of the notorious jesuits. 


\section{APRESENTAÇÃO}

A Companhia de Jesus foi formada numa época em que a sociedade portuguesa e a espanhola estavam passando por um profundo processo de aprofundamento do sentimento de intolerância contra todos os descendentes dos judeus convertidos ao catolicismo, denominados cristãos novos, conversos ou marranos.

Quatro anos antes da criação da Ordem, em 1536, havia sido instalado o Tribunal do Santo Ofício da Inquisição em Portugal, que se caracterizou pelo extremo racismo, elitismo e por aplicar métodos processuais arbitrários que amedrontavam a todos portugueses, cristãos novos ou cristãos velhos. Sua violência desmedida levou muitos de seus réus a serem queimados vivos na fogueira ou reduzido à miséria milhares de portugueses.

O clero católico, principalmente o ibérico, foi um elemento decisivo na disseminação do anti-judaismo moderno. Seus sermões eram carregados de estereótipos anti-semitas. Assimilou com certa facilidade a intolerância ibérica e desempenhou um papel determinante na formação do estigma de "impuro" que marcou todos os portugueses de origem judaica.

A monarquia portuguesa - tradicionalmente aberta ao pensamento humanista - tornava-se cada vem mais impregnada pelo sentimento de intolerância contra todos os descendentes de judeus. A nobreza conservadora passou a ocupar cada vez mais o poder político e a influenciar as decisões do monarca e da Igreja católica. D. João III e seu irmão, cardeal e inquisidor geral de Portugal, D. Henrique, 
desempenharam um papel determinante na perda progressiva de poder político do grupo esclarecido e tolerante.

A situação político-econômica de Portugal apresentava sinais de crise. O comércio ultramarino enfraquecia e algumas colônias africanas estavam sendo perdidas.

Na Espanha a condição do cristão novo não era muito diferente. O Tribunal do Santo Ofício da Inquisição já estava em funcionamento desde 1478, aprovado pelo papa Sisto IV, atendendo ao pedido dos reis católicos. A Inquisição espanhola possuía poderes discricionários em relação aos crimes de "heresia”, principalmente a judaica. Como em Portugal, a grande maioria dos réus era de conversos e as penas aplicadas aos condenados foram idênticas às do Tribunal português.

A nobreza espanhola resistiu à presença dos conversos na Companhia de Jesus, pressionando para que a Ordem os excluísse.

Os Estatutos de Limpeza de Sangue foram gradativamente adotados por todas as instituições, inclusive pelas Ordens religiosas, e os descendentes de judeus, árabes, negros, mulatos e ciganos foram excluídos. Em 1540 já estavam disseminados por toda Península Ibérica.

A intolerância Ibérica, quando da formação da Companhia de Jesus, já estava em acelerada disseminação. Este processo continuou e atingiu também a Ordem fundada por Inácio de Loyola, até o momento dela excluir, definitivamente, todos os candidatos que tivessem origens judaicas.

Entretanto, mesmo no contexto da intolerância da Península Ibérica, a primeira geração dos jesuítas recebeu numerosos cristãos novos.

O primeiro capítulo trata das circunstâncias que levaram a Companhia de Jesus a recebê-los. ${ }^{1}$ Três foram as razões principais. Por ser uma Ordem recémformada, necessitava de sacerdotes. Como a Companhia de Jesus foi criada no contexto da Reforma, os cristãos novos, além de desejarem ingressar na Ordem para fugirem das perseguições, desempenharam um papel importante no combate ao 
protestantismo. A terceira razão se deveu à existência de humanistas tolerantes nas Penínsulas Ibérica e Itálica. Eles facilitaram o recebimento dos conversos em Portugal e Espanha. E quando eram discriminados nestes dois reinos, possibilitaram a transferência para a Itália renascentista.

No segundo capítulo tratarei dos ideais religiosos da Companhia de Jesus inspirados por seu fundador, Inácio de Loyola. A meta da nova Ordem era fazer a "redenção do mundo e da humanidade". Os inimigos deveriam ser vencidos, entretanto, seriam vencidos pelo amor.

Para ser alcançado o "bem universal”, quer dizer, a "redenção do mundo e da humidade”, a Companhia necessitaria do apoio político das cortes, reis, príncipes, dos religiosos, dos homens que exercessem funções públicas e tivessem influência pelo saber e autoridade.

Apesar do propósito universalista da Companhia de Jesus, alguns anos após a sua fundação, ela criou uma série de impedimentos discriminadores.

Veremos as consequências para os cristãos novos da opção que a Ordem fez de se aliar aos setores privilegiados da sociedade da época.

No terceiro capítulo mostrarei as primeiras medidas normativas da Companhia de Jesus discriminando os cristãos novos, como por exemplo, o regimento do Colégio da Companhia de Jesus de Coimbra que os excluiu. Farei uma breve análise das causas desta exclusão.

Ao mesmo tempo considerarei a postura do fundador da Companhia de Jesus, Inácio de Loyola, em relação aos cristãos novos. Inicialmente Loyola os recebia; enquanto não causassem indisposição com as camadas privilegiadas da sociedade, como ocorreu com o arcebispo da Arquidiocese de Toledo, Juan Martinez Siliceo.

Após o Regimento do Colégio da Companhia de Jesus de Coimbra entrar em vigor, os documentos normativos da Companhia de Jesus passaram a inserir o tema do cristão novo, procurando dificultar sua inclusão, inclusive nas próprias Constituições aprovadas em 1558 pela primeira Congregação Geral.

\footnotetext{
${ }^{1}$ Alguns documentos em espanhol foram traduzidos por mim. Enquanto outros não traduzimos.
} 
O quarto capítulo será dedicado à presença dos cristãos novos nas missões orientais. Veremos que o primeiro cristão novo a chegar nas Índias Orientais, Henrique Henriques, foi discriminado pelo cristão velho Antônio Gomes, entretanto ele conseguiu assumir um cargo de comando, do qual, depois de algum tempo, foi demitido.

Nos depararemos com um conflito entre dois cristãos novos, que pode ter sido forjado pelos cristãos velhos.

Veremos que cristãos velhos jesuítas lusitanos não queriam que os cristãos novos portugueses da Companhia fossem enviados para as missões orientais. Em 1575 uma consulta aprovou a exclusão dos conversos da Província de Goa. Posteriormente, houve uma campanha contra a participação deles em cargos de relevo da Província. Politica que logo tornou-se vitoriosa, obtendo inclusive o apoio do Vigário Geral Cláudio Acquaviva.

O quinto capítulo versa sobre o papel que a da Companhia de Jesus desempenhou na instalação do Tribunal do Santo Ofício da Inquisição em Goa. Tratarei a respeito dos escritos "blasfemos" encontrados em Cochim e farei uma retrospectiva do comportamento dos jesuítas em ralação aos cristãos novos.

Ao constatar que a Inquisição chegou em Goa graças, principalmente, às demandas feitas pelos jesuítas, o sexto capítulo revela como ocorreu a relação entre o Tribunal do Santo Ofício e a Companhia. Veremos que houve, no primeiro momento, interesses comuns entre ambas as instituições. A Companhia de Jesus prestou uma série de serviços à Santa Inquisição de Goa, desde a confissão dos condenados, passando pelos sermões nos autos-de-fé, até à elaboração e assinatura das sentenças.

Com o transcorrer do tempo alguns jesuítas começaram a questionar a conveniência da Companhia de Jesus continuar participando do Santo Oficio da Inquisição. As divergências a esse respeito continuaram até o ano da aprovação do Estatuto de Limpeza de Sangue, 1593. 
O cristão novo Duarte de Sande foi indicado pelo Provincial Rui Vicente para ser inquisidor. O motivo da indicação: “limpar o sangue” de Duarte de Sande.

Constataremos a solidariedade prestada por um jesuíta cristão novo a um converso que havia sido prisioneiro da Inquisição e a recriminação que recebeu dos cristãos velhos o autor do gesto.

No que diz respeito à América, especialmente à Província do Peru, os jesuítas questionaram a viabilidade da Companhia continuar servindo ao Tribunal do Santo Ofício da Inquisição de Lima, da mesma forma que estava ocorrendo no Oriente.

No Brasil praticamente não houve problemas com os cristãos novos jesuítas até 1593, exceto o caso obscuro da morte do cristão novo Leonardo Nunes. Analisarei os motivos da viagem e a controversa causa da sua morte.

O capítulo sétimo será dedicado à relevância da participação do fundador da Companhia de Jesus, Inácio de Loyola, na consolidação da Inquisição portuguesa. A aceitação pelos jesuítas reunidos em Roma da proposta feita pelo monarca português, D. João III, para a Inquisição de Lisboa ter um inquisidor jesuíta.

Veremos ainda a sugestão que Diego Mirão S. J. fez para a Companhia dirigir a inquisição portuguesa. Neste Tribunal os inacianos participaram dos auto-de-fé, dos sermões, das confissões, denúncias e do Conselho Geral.

A oposição aos cristãos novos tornou-se mais intensa a partir da terceira Congregação Geral. Nesta, os jesuítas portugueses tentaram aprovar a exclusão dos cristãos novos e foram os principais articuladores do movimento contrário à eleição do cristão novo Juan Alfonso de Polanco para o cargo de Vigário Geral da Companhia de Jesus. Proporam, várias vezes, a exclusão dos conversos, até conseguir o apoio parcial do Vigário Geral Cláudio Acquaviva.

No oitavo capítulo, notaremos que depois de um período inicial de entendimento entre o Santo Ofício espanhol e a Companhia de Jesus, inclusive com vários jesuítas contribuindo com o Tribunal, posteriormente houve vários desentendimentos. A Inquisição chegou até a se imiscuir na presença dos cristãos novos na Companhia. 
A intolerância dos jesuítas espanhóis contra os cristãos novos inacianos foi se intensificando com o transcorrer do tempo. Nas vésperas da quinta Congregação Geral eles exerceram um papel decisivo na “campanha” difamatória dos conversos, durante a qual o converso José de Acosta sofreu os maiores ataques.

Evidenciaremos ainda a intolerância da nobreza espanhola contra os cristãos novos. Veremos também que a discriminação contra os conversos atingiu também a outrora tolerante Roma.

No capítulo final consideraremos a quinta Congregação Geral da Companhia de Jesus. Houve uma campanha deliberada para evitar a presença dos cristãos novos na referida Congregação, sendo o converso José de Acosta o único participante cristão novo, graças ao pedido de rei da Espanha, Felipe II.

O último e definitivo ataque aos cristãos novos consistiu em acusá-los de serem os autores dos “memoriais" - documentos contrários à forma de organização da Companhia de Jesus.

Nos dias que antecederam à Congregação, o cristão novo Pedro de Ribadeneira fez uma defesa exaustiva dos cristãos novos. Listou treze razões para a Companhia de Jesus não os excluir.

No dia 23 de dezembro de 1593 o "Estatuto de Limpeza de Sangue" da Companhia de Jesus foi aprovado. O decreto 52 da Quinta Congregação Geral justificou a exclusão dizendo que os cristãos novos causavam "obstáculos e danos à Companhia de Jesus".

O padre José de Acosta foi contrário ao decreto, ao seu lado ficou o jesuíta Árias. Mas sem obterem nenhum sucesso.

Após a aprovação, um grupo de jesuítas tentou amenizar, em vão, o rigor do Decreto 52. 


\title{
CAPÍTULO I. OS CRISTÃOS NOVOS NA FORMAÇÃO DA COMPANHIA DE JESUS
}

\author{
OS ESTATUTOS DE LIMPEZA DE SANGUE
}

Os Estatutos de Limpeza de Sangue, que excluíam os descendentes de judeus e mouros das Ordens Militares, Ordens Religiosas, Catedrais, Monastérios, Universidades e Colégios, já se encontravam disseminados por toda Espanha. As Ordens Militares começaram a adotá-los em 1483 (Ordem de Alcântara). Várias Ordens Religiosas já os havia implementado como, por exemplo, a de São Gerônimo (1495). Os franciscanos adotaram em 1525 e o Monastério dominicano de Santo Tomás de Aquino de Ávila em $1496^{2}$. A Igreja de Sevilha estabeleceu o seu Estatuto de Limpeza de Sangue em 1515 - talvez o primeiro Estatuto de uma Catedral a rechaçar de todos os cargos e benefícios pais e filhos descendentes de hereges, referência indireta às "raças infectas", ou seja, os cristãos novos ${ }^{3}$. A Igreja de Toledo elaborou o seu Estatuto em 1547, aprovado pelo papa Paulo IV em $1555^{4}$. Em 1547 houve em Toledo uma nova série de perseguições contra os conversos, lideradas pelo Arcebispo Silíceo e o Cardeal Poggio, os quais acusaram os judeus de

\footnotetext{
${ }^{2}$ Veja a respeito dos Estatutos de Limpeza de Sangue das Ordens religiosas e militares, ORTIZ, António Dominguez. Los Judeosconversos en la España Moderna. Madrid, Editorial Mapfre, 1993, pp.149-152. Ver também Reites, W. James, S. J. "Ignatius of Loyola and the Jews". In Studies in the Spirituality of Jesuits. (U.S.A). Vol. XIII, N. ${ }^{\circ}$ 4, September, 1981, p. 20.

${ }^{3}$ SICROFF, Albert. Los Estatutos de Limpieza de Sangre. Controversias entre los siglos XV e XVII. Madrid, Tauros, 1981, p.120.

${ }^{4}$ A cidade de Toledo ("una asamblea del pueblo") já havia estabelecido um Estatuto de Limpeza de Sangue (Sentencia-Estatuto) em 1449, decorrente das "sublevações anticonversas" ocorridas no mesmo ano.Ver a esse respeito, SICROFF, Albert.Op. cit., pp.51-56.
} 
serem os “piores inimigos de Cristo”. Ameaçaram queimar os cristãos novos. Além disso, tentaram expulsá-los da Igreja de Toledo ${ }^{5}$.

Os Estatutos de Limpeza de Sangue também foram implantados numa série de Universidades e nos Colégios Maiores. No caso das Universidades de Salamanca, Valladolid e Toledo, a Inquisição as proibiu de conceder diplomas aos conversos, seus filhos e netos ${ }^{6}$. Os Colégios Maiores foram mais rigorosos do que as Universidades na aplicação dos Estatutos: "Si las universidades fueron poco estrictas en esta materia, los colegios mayores se jactavan de ser los más exactos y puntilloso en cuestión de estatutos"”. Os Colégios pressionaram as Universidades para que elas fossem mais rigorosas na aplicação dos seus estatutos, já que muitas delas eram controladas pelos Colégios Maiores ${ }^{8}$.

\section{A INTOLERÂNCIA CONTRA OS CONVERSOS E AS ADMISSÕES}

\section{REALIZADAS PELA COMPANHIA}

As condições políticas e religiosas não eram favorávis aos cristãos novos. Portugal com o seu Tribunal instalado em 1536; Espanha completando sessenta anos de atuação do Santo Ofício e vivendo em um universo mental no qual, conforme as palavras de Albert Sicroff, “O princípio e limpeza de sangue havia se tornado em uma espécie de dogma da religião e da nacionalidade espanholas"

\footnotetext{
${ }^{5}$ Ver a esse respeito SICROFF, Albert. Idem, pp.132-170.

${ }^{6}$ Ver ORTIZ, António Dominguez. Op. cit., p.161. Na realidade, Ortiz cita o livro de Henry Charles Lea, “La Historia de la Inquisición Española”.

${ }^{7}$ Ver ORTIZ, António Dominguez. Idem, p.162.

" “No obstante, como muchas universidades estaban íntimamente unidas a los colegios e incluso dominadas por ellos, los estatutos de éstes les afectaban de alguna manera.” ORTIZ, António Dominguez. Idem, p.161.

${ }^{9}$ SICROFF, Albert. Op., cit., p.216. Henry Kamen minimiza a importância da limpeza de sangue. Para ele, os Estatutos de Limpeza de Sangue (forma jurídica da Limpeza de Sangue) foram praticamente ineficazes na sua função prática de discriminar os cristãos novos: "El antisemitismo existía, pero los estatutos discriminatorios de limpieza perdieron fuerza y tuvieron poca influencia real en sus vidas”. KAMEN, Henry. La Inquisición Española. Una revisión histórica. Barcelona, Editorial Crítica, 1999, p.273.
} 
Principalmente na Península Ibérica, berço da Companhia de Jesus, no contexto político, religioso e cultural da época da fundação da Companhia de Jesus e das primeiras décadas da sua existência, não era aconselhável para os jesuítas receber em sua Ordem pessoas "suspeitas", e menos ainda aqueles, comprovadamente, cristãos novos. Apesar disso, "a Companhia de Jesus foi concebida com a colaboração enérgica de cristãos novos”"10.

Como vimos, Toledo foi um centro anticonverso. Foi também em Toledo que surgiu a denúncia, formulada por jesuítas aí residentes, de que Diogo Laínez era de origem judaica (mesmo assim chegou a ser o Geral da Ordem). Além dessa denúncia, em Roma, Juan Polanco (secretário da Companhia) foi considerado suspeito de ser cristão novo ou simpatizar com eles. Comprovou-se, posteriormente, ambos serem de origem judaica. Entretanto, permaneceram na Companhia de Jesus até o final das suas vidas, apesar de Juan Polanco ter sua indicação negada para ser o Vigário Geral da Ordem, devido à sua ascendência judaica.

Outros nomes de cristãos novos se destacaram entre os inacianos: Francisco de Toledo (cardeal), Jerónimo Román de la Hiquera, Pedro de Ribadaneira, Juan de Mariana, José de Acosta, Henrique Henriques, Leonardo Nunes, Duarte de Sande, Gomes Vaz, Antônio Vaz, Cipriano Soares, Afonso de Castro e Lourenço Pinheiro.

\section{MOTIVOS PARA A ADMISSÃO}

A admissão dos cristãos novos no início da formação da Companhia se deveu, muito provavelmente, à necessidade do aumento de membros. Os fundadores necessitavam de elemento humano para viabilizar a existência da Companhia e fazêla crescer rapidamente.

\footnotetext{
${ }^{10}$ SICROFF, Albert. Op. Cit., p.315.
} 
Esta razão, entretanto, não parece esclarecer plenamente a questão da presença de conversos entre os inacianos. Por um lado, o que aparentemente demonstrava ser uma solução simples e fácil para o rápido crescimento, poderia se tornar a causa do fracasso, pois os demais membros da nova Ordem, supostamente homens conscientes da realidade onde viviam, sabiam dos riscos que a Companhia de Jesus correria caso resolvessem receber os cristãos novos.

Consideremos agora a Ordem de São Domingos a fim de compararmos a questão da tolerância com a da Companhia de Jesus. Desde a sua fundação (1216) os dominicanos se destacaram pela sua dedicação à Inquisição. A maioria dos inquisidores era de dominicanos, assim como também foram eles que praticaram os atos mais violentos durante a época da Inquisição Papal. A situação chegou a tal ponto que foram expulsos de Tolosa (1233), Norbona e de outras povoações do sul da França nesse mesmo ano ${ }^{11}$.

Na Inquisição moderna os primeiros inquisidores foram todos dominicanos, inclusive o primeiro inquisidor geral da Espanha, Tomás de Torquemada, que solicitou e obteve do Papa Alexandre VI, em 1496, o primeiro Estatuto de Limpeza de Sangue para sua Ordem (monastério de Santo Tomás de Aquino, em Ávila). Henry Kamen mostra o papel desempenhado por Tomás Torquemada no estabelecimento do Tribunal do Santo Ofício em Castela, após as "provas" apresentadas pelo dominicano Alonso de Hojeda de que houve uma reunião de conversos judaizantes em Sevilha:

"Ao parecer, o governo ficou convencido e encarregou que lhe informasse da situação de Sevilha. O informe, apoiado pela autoridade de Pedro Gonzáles de Mendoza, arcebispo de Sevilha, e de Tomás de 
Torquemada, prior de um convento dominicano em Segóvia, apontava que os conversos praticavam ritos judeus em segredo não só em Sevilha, senão em toda Andaluzia e Castela. Dando o testemunho por válido, Fernando e Isabel deram seu consentenimento para para que se intruduzisse a maquinaria inquisitoirial em Catela e pediram a Roma que outorgasse a bula para seu estabelecimento." ${ }^{\text {,12 }}$.

Posteriormente, "Fernando e Isabel dirigiram-se a Roma e solicitaram uma bula do Papa Sixto IV, que nomeasse o antigo prior do convento de Santa Cruz em Segóvia, Tomás de Torquemada (Turrecremata), confessor de Fernando.”13. Em 1481 o papa Sixto IV publicou a bula ao mesmo tempo em que nomeou Tomás de Torquemada grão-inquisidor ${ }^{14}$.

A primeira Catedral a adotar um Estatuto de Limpeza de Sangue tinha como Arcebispo um dominicano, Diego de Deza ${ }^{15}$. O estabelecimento da Inquisição em Roma ocorreu também graças aos esforços dos dominicanos, curiosamente, com o apoio de Inácio de Loyola. Havia duas atitudes relativamente diferentes. Ambas as Ordens participaram do Tribunal do Santo Ofício da Inquisição, mas a Companhia de Jesus somente adotará o Estatuto de Limpeza de Sangue na última década do século XVI.

A segunda razão possíveol foi a Contra-Reforma. Para conter o avanço dos protestantes e recuperar as perdas por estes provocadas, a Igreja Católica precisava

\footnotetext{
${ }^{11}$ Ver HERCULANO, Alexandre. História da Origem e Estabelecimento da Inquisição em Portugal. Tomo I, VIII Edição. Lisboa, Livrarias Aillaud e Bertrand, s/d, pp.35-57.

${ }^{12}$ KAMEN, Henry. La Inquisición Española. Una revisión histórica. Op. cit., p.48.

${ }^{13}$ KAYSERLING, Meyer. História dos Judeus em Portugal. São Paulo, Livraria Pioneira Editora, 1971, p.80. , p.80

${ }^{14}$ KAYSERLING, Meyer. Idem, ibidem.

${ }^{15}$ Antonio Domingues Ortiz diz que "el primer estatuto de limpieza de sangre para el ingresso en um cabildo catedralico fue el de Badajoz” e não o de Sevilha, como supõe Albert Sicroff.
} 
de clérigos. Uma das fontes disponíveis para suprir esta carência era, sem dúvida, os cristãos novos. O catolicismo romano necessitava recuperar seu poder.

A Companhia de Jesus foi quem mais recebeu cristãos novos, assumindo o risco de se indispor com outras Ordens, com as Coroas Ibéricas, o Tribunal do Santo Ofício, e com as nobrezas espanhola e portuguesa.

Podemos dizer que os jesuítas da primeira geração tiveram certa tolerância com os cristãos novos. Resta ainda outra possível razão: a influência dos humanistas sobre aquela geração.

Das três prováveis razões que apresentamos, esta última tem algo muito peculiar, pois não existem evidências diretas ou documentais comprovando a influência que os humanistas exerceram sobre os jesuítas da primeira geração. Como não se conhecem documentos a esse respeito, vejamos o contexto histórico criado pelo humanismo.

Antes de considerarmos as suas características fundamentais, faremos uma breve observação. Inácio de Loyola e os demais fundadores da Companhia de Jesus estudaram na Universidade de Paris. Esta Universidade não aceitava ou não aprovava, "de um modo geral”, a forma de pensar e de agir dos dominicanos ${ }^{16}$. Por isso, é possível supor que os jesuítas pioneiros tivessem adotado uma postura mais flexível do que os seus coirmãos na fé.

\section{$\underline{\text { O HUMANISMO }}$}

Havia uma “Itália”, berço do humanismo e ao mesmo tempo, sede da Igreja Católica Romana. Foi nesta Itália, principalmente a partir de Florença, Veneza e

\footnotetext{
${ }^{16}$ Ver a esse respeito HERCULANO, Alexandre. Op.cit., tomo I, p.57.
} 
Ferrara - "primeira cidade realmente moderna da Europa" -, que a Renascença se disseminou pelo continente europeu.

Ao tentar entender os motivos do precoce desenvolvimento geral dos habitantes da Península Itálica, Jocob Burckhardt disse que "no caráter desses Estados, repúblicas ou despotismos, está não a única, mas a principal razão para o desenvolvimento precoce dos italianos". E continua, "isso se deve ao fato de que eles são os primogênitos, entre os filhos da Europa moderna”... E mais, “Todo o povo se ocupava daquilo que nas cidades despóticas era assunto de uma só família". Esta é, portanto, a razão do desenvolvimento geral dos “italianos”: o debate democrático das grandes questões políticas.

As principais características de Florença, primeiro Estado moderno, segundo Jacob Burchardt, eram: I) Sede das doutrinas e teorias políticas; II) Sede das experiências e mudanças repentinas; II) Junto com Veneza, sede da ciência estatística; III) Sede da representação histórica no sentido moderno da expressão. O autor concluiu dizendo que os florentinos devem a Florença a liberdade e independência intelectual ${ }^{17}$.

Já Veneza seria um Estado caracterizado pelo “cuidado com o povo”, e devido a esse cuidado, "Estado algum jamais exerceu uma influência moral mais importante sobre os seus súditos". Veneza primava pelo "gozo da vida e do poder", desenvolveu uma "indústria de máxima lucratividade" e abriu novas rotas comerciais $^{18}$.

A Itália tornou-se o berço da modernidade devido às suas ralações estritas e contínuas com os bizantinos e maometanos. Os italianos conceberam uma tolerância

\footnotetext{
${ }^{17}$ Ver BURCKHARDT, Jacob. A Cultura do Renascimento na Itália: um ensaio. Brasília, Editora da Universidade de Brasília, 1991, pp.49-50. Jacob Burckhardt disse mais adiante (p.304) que Florença foi a sede do "mundanismo". Este teria se originado dos novos pensamentos, propósitos e pontos de vista, que transformaram o conceito de natureza e do homem.

${ }^{18}$ BURCKHARDT, Jacob. Op.cit., pp.42-47.
} 
sem paixões, a qual fragilizou a visão etnográfica de uma Cristandade privilegiada. Conquistou o mundo ocidental não apenas por ter sido o palco do florescimento da Antiguidade, mas devido à união desta com a índole do povo; para a Itália, a Antiguidade era o seu maior título de glória. A noção de humanidade na Itália se tornou um fato. Ela possibilitou o tratamento objetivo das questões do Estado e do mundo em geral, ao mesmo tempo em que deu vazão à subjetividade. O homem se tornava um indivíduo espiritual, e assim se reconhecia. Os italianos foram os primeiros europeus a especular sobre a "liberdade" e a "necessidade"19.

\section{ALGUNS HUMANISTAS DE DESTAQUE}

Retomemos alguns aspectos do pensamento de alguns dos mais destacados humanistas. Um dos temas mais importantes que os humanistas consideraram em suas reflexões foi a questão religiosa. Dois pensadores que trataram da questão, Nicolau de Cusa e Marsílio Ficino, se mostraram tolerantes com as chamadas “religiões históricas”. Neste sentido, estes humanistas foram pioneiros na defesa da liberdade de consciência no Ocidente. "Eles supunham que existia uma tradição comum a todas as religiões e que o conhecimento desta bastava para a salvação, $e$ que, em suma, todas as religiões se equivalem" ${ }^{20}$. Nicolau de Cusa não era italiano, mas morou em Florença, onde exerceu o seu sacerdócio. Segundo Ernest Cassirer, em Nicolau de Cusa

\footnotetext{
${ }^{19}$ Ver sobre os fatores que constituíram a modernidade italiana em BURCKHARDT, Jacob. Idem. Chamamos a atenção para o fato de que as características da modernidade italiana se encontram dispersas ao longo da obra de Jacob Burckhardt (pp.302, 105, 124, 214, 81 e 304). Portanto, a ordem como elas estão colocadas acima é uma tentativa de sistematizarmos as causas da modernidade na Itália.

${ }^{20}$ ELIADE, Mircea. O Sagrado e o Profano: a essência das religiões. Lisboa, Edição "Livros do Brasil”, 19--, p.16. Entretanto, Nicolau Maquiavel e Guichiardine apoiram a expulsão dos judeus da Espanha. Veja a esse respeito, POLIAKOV, Léon. São Paulo, Perspectiva, 1996, p.171.
} 
“(...) a diversidade de ritos deixa de constituir um empecilho, pois todas as instituições e todos os usos e costumes nada mais são do que signos da verdadeira fé, e somente esses signos estão sujeitos a transformações, a modificações, não os seus referentes”21.

Portanto, tendo as religiões os mesmos referentes, a "concordantia”, para Nicolau de Cusa "pode estabelecer-se não só entre o Papa e o Concílio, as Igrejas do Ocidente e do Oriente, como também entre o Cristianismo e as religiões históricas"22.

O pensamento de Marsílio Ficino é praticamente idêntico ao de Nicolau de Cusa no tocante à religião. Entretanto, ele possui algo que os diferencia. Trata-se da humanização de Cristo do ponto de vista do estoicismo antigo. Essa idéia de Cristo assim humanizado possibilitou o afastamento gradativo da filosofia do dogmatismo cristão ao legitimar as religiões na "totalidade das formas históricas". De acordo com Ernest Cassirer, Marsílio Ficino "introduziu uma modificação na idéia de Cristo, através da qual ela se transforma imediatamente na idéia de humanidade, entendida esta última em seu sentido antigo, estóico”. E continua,

“(...) deste ponto em diante torna-se viável uma história da filosofia que, por mais que permaneça no círculo do pensamento dogmático do cristianismo, vai vencendo cada vez mais a estreiteza do dogma à medida que tende a enxergar o conceito de religião corporificado não

\footnotetext{
${ }^{21}$ CASSIRER, Ernest. Indivíduo e Cosmos na Filosofia do Renascimento. São Paulo, Martins Fontes, 2001, p.50.

${ }^{22}$ ELIADE, Mircea. História das Crenças e da Idéias Religiosas. De Maomé à Idade das Reformas. Tomo III. Rio de Janeiro, Zahar Editores, 1984, p.241.
} 
exclusivamente numa única fé, mas na totalidade das formas históricas de fé, 23 .

A tolerância religiosa teve em Damião de Góis um dos seus maiores representantes europeus. Elogiou, abertamente, os judeus em seus escritos, dialogou com os protestantes tendo em vista a sua reconciliação com a Igreja de Roma, defendeu a Igreja Etíope e foi tolerante com as culturas dos nativos da América Portuguesa ${ }^{24}$.

Durante o reinado de D. Manuel houve um período relativamente mais calmo em Portugal, com exceção do massacre de 1506. Ainda existia em Portugal um espírito tolerante que permitia discussões abertas sobre religião, filosofia e história.

Damião de Góis foi um dos exemplos mais eloqüente desse momento. Talvez por issofoi perseguido posteriormente pela Inquisição, morrendo no cárcere e na miséria.

Aconteceu na Itália uma ruptura profunda no pensamento religioso. O responsável por essa ruptura foi Lorenzo Valla. Para ele a "essência da religião consiste numa relação livre que se estabelece entre o eu, o sujeito da fé e da vontade e a divindade״25. Quer dizer, negou a necessidade de uma religião institucionalizada e oficial, dispensando, com isso, a figura do intermediário, do especialista nas questões divinas: o sacerdote.

Para Jacob Burckhardt esse deslocamento do institucional para o individual foi inevitável entre os humanistas italianos: "que a religião deveria voltar a ser um

\footnotetext{
${ }^{23}$ CASSIRER, Ernest. Idem, p.119.

${ }^{24}$ Ver sobre Damião de Góis HISCH, Elisabeth Feist. Damião de Góis. Fundação Calouste Gulbenkian, 1987. Veja especialmente as páginas 12-13, 112 e 165, onde se encontram exemplos da tolerância de Damião de Góis.

${ }^{25}$ CASSIRER, Ernest. Op. cit., p.132.
} 
assunto do indivíduo e do seu sentimento pessoal era inevitável, quando a Igreja se tornou corrupta na doutrina e tirânica na prática, e é uma prova de que a mente européia ainda estava viva” ${ }^{26}$. Em outras palavras, devido à força moral e ética do humanismo, seus adeptos dotaram-se de um senso crítico capaz de recriminar a atuação da mais poderosa instituição existente no mundo europeu de então: a Igreja Católica Romana.

Vimos assim algumas das linhas mestras do pensamento de alguns dos mais destacados pensadores humanistas. Eles inauguraram um novo período na vida intelectual da Europa e foram os precursores da modernidade européia. Praticamente ninguém ficou indiferente a esta retomada do mundo clássico. Nem a religião católica tampouco o poder político foram capazes de saírem ilesos diante do novo mundo que se anunciava com tanta força. António José Saraiva escreveu que "o humanismo mantinha o seu ascendente dentro das classes dirigentes incluindo altos dignatários” e cita a Universidade de Alcalá de Henares como exemplo “de uma tentativa de conciliação do humanismo com a teologia, do conhecimento das línguas clássicas e a hebraica com a interpretação ortodoxa da escritura e contavam-se dentro dela muitos admiradores de Erasmo"27.

De acordo com o mesmo autor, a Corte de D. João III era composta “de príncipes da Igreja dados à literatura e às belas-artes, muitos deles penetrados de espírito humanista, alguns profundamente cristãos, outros tolerantes até ao cepticismo" 28 .

E a Companhia de Jesus deve ter ouvido, com muita atenção, o que aqueles pensadores diziam. Estamos convencidos de que, por exemplo, os ideais de tolerância religiosa de Nicolau de Cusa e de Marsílio Ficino influenciaram a primeira geração dos jesuítas. Roma, sede da Igreja Católica e da Ordem dos

\footnotetext{
${ }^{26}$ BURCKHARDT, Jacob. Op.cit., p.303.

${ }^{27}$ SARAIVA, António José. História da Cultura em Portugal. Vol. 1, Renascimento e ContraReforma. Lisboa, 2000, p.191.
} 
jesuítas, viveu de perto o humanismo ${ }^{29}$ e Inácio de Loyola com os companheiros que aceitarem os cristãos novos, reconheceram que estes tinham o direito legítimo de serem jesuítas ${ }^{30}$.

Em 1543 o Vigário Geral Inácio de Loyola fundou, em Roma, a Casa de Catecúmenos com o intuito de receber os crisão novos ${ }^{31}$. Nesta casa, por exemplo, o próprio Inácio de Loyola recebeu Juan Bautista Eliano Romano (Salomón Romano), neto do rabino asquenazi Elías Levita (ha-Levi) ${ }^{32}$.

Em janeiro de 1553 Francisco de Borja admitiu o cristão novo Garpar Loarte. Em 1554 foi nomeado por Inácio de Loyola reitor do Colégio de Gênova. Em agosto do mesmo ano Francisco de Villanueva recebeu em Alcalá de Henares o médico converso Alfonso de Pisa. Enviado para Roma, Inácio de Loyola o incubiu à cátedra de Físico do Colégio Romano. Neste mesmo ano Jerônimo Nadal S. J. admitiu o licenciado Luis de Santander. ${ }^{33}$

\footnotetext{
${ }^{28}$ SARAIVA, António José. Inquisição e Cristãos novos. Lisboa, Editorial Estampa, 1984, p.48.

${ }^{29}$ João Lúcio de Azevedo assim se referiu à Roma renascentista: "Ela era com certeza a terra menos intolerantemente religiosa da cristandade." Azevedo, João Lúcio de. História dos Cristãos novos Portugueses. Lisboa, Clássica Editora, 1989, p. 67.

${ }^{30}$ Duas cartas de Inácio de Loyola comprovam o ambiente tolerante vivido em Roma, e a respectiva influência exercida sobre os jesuítas. No mês de Agosto de 1553, ao tratar da questão do ingresso dos cristãos novos na Província espanhola, escreveu: "Pero bien le parece se debría de tener con los tales más circunspectión. Si allá por los humores de la corte ó del rey no pareciere se deban admitir, inbiense acá" (grifo nosso). In Monumenta Ignatiana. Series I, T. V. Madrid, 1907, p. 335. Em Fevereiro de 1555, recomendou ao Provincial de Portugal, Diogo Mirão que enviasse para a Itália os cristãos novos portugueses, caso o rei não aceitasse sua presença em Portugal: "y ellos, siendo buenos sugetos, se pueden enbiar á las otras províncias d'España, ó para estas partes de Itália, donde no ay esos respetos.”. In Monumenta Ignagtiana, Series Prima, Epistolae et Instructiones, Tomus Octavus, Matriti, 1909, p. 446.

${ }^{31}$ Ver a esse respeito Medina, Francisco de Borja. San Ignacio y los Judios. In Anuario del Instituto Ignacio de Loyola, n. ${ }^{0}$ 4. San Sebastián, 1997, p. 48.

${ }^{32}$ Ver Medina, Francisco de Borja. Idem, p. 53.

${ }_{33}$ As informações a respeito do ingresso desses cristãos novos na Companhia de Jesus encontram-se em Medina, Francisco de Borja. Idem, pp. 54-55. Uma ressalva: seria impossível que Gaspar Loarte tenha sido admitido na Companhia em janeiro de 1553, como informou Francisco de Borja Medina, porque em julho do mesmo ano ele escreveu, junto com Diego de Guzman, uma carta para o padre Antônio Araoz reclamando a rejeição do seu ingresso. Ver Epistolae Mixtae. Tomus tertius (1553). Matriti, 1900, pp. 392-93. Em ralação aos demais ingressos citados, não foi encontrada nenhuma fonte confirmando-os, tampouco Francisco de Borja Medina as citou.
} 
Graças ao legado humanista, mesmo que tenha sido indireto, a primeira geração dos inacianos recebeu e conviveu, de forma relativamente harmônica, com os seus “irmãos” cristãos novos.

Contudo, a influência do humanismo sobre os jesuítas foi limitada no tempo e no espaço. Desde a fundação da Companhia de Jesus outras forças contrárias ao pensamento dos humanistas estavam agindo com influência cada vez maior. 


\section{CAPÍTULO II. A COMPANHIA DE JESUS: SEUS IDEAIS E SUAS TRANSFORMAÇÕES}

Em 27 de setembro de 1540 - através da Carta Apostólica "Regimini militantes Ecclesiae” - foi criada pelo Papa Paulo III a Companhia de Jesus.

Dentre os cinco primeiros membros que se aproximaram de Inácio de Loyola, portanto fundadores da Companhia de Jesus, três eram espanhóis e um português ${ }^{34}$.

A nova ordem foi duplamente confirmada, em 1544 com a Carta Apostólica Iniunctum nobis assinada pelo mesmo papa, e em 1550 sob o pontificado de Júlio III (Carta Apostólica “Exposcit debitum”).

O jovem Inácio de Loyola, idealizador da Companhia de Jesus, formou-se em filosofia no Colégio Santa Bárbara em 1534. Antes mesmo de criar a Ordem ele já havia escrito exercícios de conteúdo religioso que deveriam ser aplicados aos noviços. Ficaram conhecidos como "Exercícios Espirituais"; adequavam os postulantes ao perfil cristão que Inácio de Loyola concebeu.

\section{OS EXERCÍCIOS ESPIRITUAIS}

Os "Exercícios Espirituais" continham ainda as linhas gerais do ideal espiritual de Inácio de Loyola. Seu objetivo maior era a conversão de todos os seres humanos, sem nenhuma exceção: “Ouvir o que falam as pessoas sobre a face da terra, a saber, como falam uns com os outros, como juram e blasfemam, etc. Do mesmo modo, o que falam as pessoas divinas, dizendo: 'Façamos a redenção do

\footnotetext{
${ }^{34}$ O primeiro núcleo da Companhia de Jesus foi formado a partir de 1528 com os seguintes nomes: Pedro Favre (de Villaret), Diego Laínez (castellano), o próprio Simão Rodrigues, Nicolau Bobadilla, Alfonso Salmerón (Toledo) e Inácio de Loyola (Guipuzcoa). BANGERT, W. História da Companhia de Jesus. Porto, Livraria A. I., 1972-1986, São Paulo, Edições Loyola, 1985, pp.25 e 27.
} 
género humano...”,35. Ou seja, junto com Cristo, o exercitante era chamado para fazer a "redenção da humanidade."

Segundo o padre jesuíta Spencer Custódio Filho a redenção sonhada pela Companhia de Jesus junto com Cristo, era a "causa da pessoa humana"36.

Esta causa tinha um objetivo universal, salvar todo o mundo, inclusive os inimigos a serem vencidos e os próprios jesuítas: "Minha vontade é conquistar o mundo inteiro, vencendo todos os inimigos, e assim alcançar a glória do meu Pai. Portanto, quem quiser vir comigo há de trabalhar comigo, a fim de que, seguindome na luta também me siga na glória.,37

Esta conquista do mundo através do trabalho conjunto entre Cristo e os jesuítas era uma das formas pela qual o homem amaria a Deus e alcançaria a salvação.

A fim de viabilizar este projeto, Cristo criou a Companhia de Jesus e é Ele quem a mantém, nisto acreditava Inácio de Loyola:

“A Companhia, que não foi instituída por meios humanos, também por eles não pode manter nem desenvolver, mas só pela mão onipotente de Cristo, Deus e Senhor Nosso. Só dele, portanto, se deve esperar que há de conservar e levar adiante esta obra que Ele se dignou começar para seu divino serviço e louvor e para a ajuda das almas.”38

\footnotetext{
${ }^{35}$ Loyola, Inácio de. Exercícios Espirituais. São Paulo, Edições Loyola, 2000, p.54.

${ }^{36}$ Filho. Spencer Custódio S.J. Os Exercícios Espirituais de Santo Inácio de Loyola. Um manual de estudo. São Paulo, Edições Loyola, 1994, p.84.

${ }^{37}$ Loyola, Inácio de. Op. cit., p.50.

38 “Décima Parte, Conservação e Desenvolvimento de Todo o Corpo da Companhia em seu Bom Estado.” In Constituições da Companhia de Jesus e Normas Complementares. São Paulo, Edições Loyola, 1997, p.247.
} 
O primeiro item do "Princípio e Fundamento" dos Exercícios Espirituais define as funções atribuídas ao ser humano e, além disso, diz qual o retorno que teria ao cumprir tais funções: “O ser humano é criado para louvar, reverenciar e servir a Deus nosso Senhor e, assim, salvar-se."39

A fórmula pela qual os inacianos conquistariam o mundo está dada nos Exercícios Espirituais. Seria a mesma utilizada por Cristo, que segundo Inácio de Loyola, teria vindo para consumar a lei ao condenar o assassinato, a fornicação e o perjúrio, e ao pregar o amor aos inimigos: "Mostra-se não como transgressor da lei, mas consumador, declarando o preceito de não matar, não fornicar, não perjurar e amar os inimigos: 'eu vos digo que ameis vossos inimigos e façais bem aos que vos detestam $", 40$.

As palavras que Inácio de Loyola utilizou para estabelecer o princípio pelo qual os jesuítas deveriam se relacionar com a hierarquia católica são de uma rara eloquência. Retratam extrema submissão e cega obediência:

"Devemos sempre manter - para acertar em tudo - que o branco que eu vejo é preto se a Igreja hierárquica assim o determina, crendo que, entre Cristo Nosso Senhor, o esposo, e a Igreja, sua esposa, é o mesmo espírito que nos governa e dirige para a salvação nossa”41.

Cristo, a Companhia de Jesus e a Igreja Católica são uma só “pessoa”. Uma espécie de nova “trindade” estava criada por Inácio de Loyola.

\footnotetext{
${ }^{39}$ Loyola, Inácio de. Idem, p.23.

${ }^{40}$ Loyola, Inácio de. Op. cit., p.108.

${ }^{41}$ Loyola, Inácio de. Idem, pp.136-37.
} 
Esta postura de submissão e obediência com relação à Igreja Católica será responsável por várias atitudes posteriormente assumidas pelos jesuítas, como por exemplo, sua participação no Tribunal do Santo Ofício da Inquisição, a qual analisaremos logo em seguida.

\section{ALIANÇAS COM AS FORÇAS POLÍTICAS CONSERVADORAS}

Uma escolha reveladora do caráter que a Companhia de Jesus irá adotar posteriormente foi a nítida opção preferencial pela nobreza, mais especificamente pelas elites sociais conservadoras pertencentes à vida política, econômica, cultural e religiosa.

Inácio de Loyola, em carta escrita ao padre Luís Gonçalves da Câmara em 1552, quando este tornou-se confessor do príncipe português D. João, justificou não somente a nova função do jesuíta (“...todo sucederá á mayor gloria de la su Divina Magestad”), mas decidiu que a Companhia devia dar preferência aos Reis e Príncipes, além de ter justificado sua decisão, no caso do Rei português:

"Y porque los Reys y Príncipes sean mejor servidos de la Compañía y particulares de ella, y principalmente el Rey, que há sido y es todo el bien de la Compañía, por esta se os ordena, y os mando en virtud de santa obediencia, que no os aparteis de la Corte del Rey ó de circum circa (de sus cercanías) sin especial mandato ó ordem del Rey, ó del Príncipe, (...)"42.

\footnotetext{
${ }^{42}$ Monumenta Historica Societatis Iesu. Cartas de San Ignacio de Loyola Fundador de la Compañía de Jesus. Tomo III. Madrid, IHS, Imprenta de la V. é Hijo de D. E. Aguado, Pontejos, 8, 1877, p.12.
} 
Inácio de Loyola se referia a D. João III, rei de Portugal, considerando os favores que ele tinha prestado à Companhia. O referido monarca teve enorme importância na estruturação da Companhia de Jesus no reino português ${ }^{43}$.

D. Catarina de Áustria, irmã de Carlos V, esposa de D. João III, também prestou seu apoio à Companhia de Jesus. Em 1541 o Padre Simão Rodrigues referiase à importância que o rei e a rainha representavam para a nova Ordem: "E certo, se aqui temos alguma pessoa que mais afeição e favor nas coisas de Deus N. S. nos mostre, é ele e a rainha; e é muito extremamente, que parece que Deus N. S. especialmente pôs no coração dos dois um mesmo desejo para as coisas que são no serviço do Senhor." ${ }^{44}$.

A primeira casa própria da Companhia de Jesus foi fundada em Portugal, " $S t^{0}$ Antão-o-Velho” em 1541, doada por D. João III ${ }^{45}$; em 02 de Julho de 1542 inaugurou-se o Colégio de Coimbra, “a pedido de D. João III", enquanto que a primeira Província da Companhia de Jesus foi a portuguesa, criada em 26 de Outubro de 1546.

O padre Simão Rodrigues - um dos fundadores da Companhia de Jesus e primeiro provincial de Portugal - sabia que sua presença na Corte era imprescindível para os interesses da Companhia em Portugal: "Paréceme que mandaré pedir á S. S. más gente, porque á mí com grande dificuldad me alargará de la corte, por pensar que aqui haré más fructo." ${ }^{46}$.

O rápido e ralativamente fácil e profícuo acesso da nova Ordem à realeza portuguesa foi facilitado graças à influência que Diogo de Gouveia tinha na Corte

\footnotetext{
${ }^{43}$ A esse respeito escreveu Francisco Rodrigues S. J.: "O primeiro e maior benfeitor, não só da Província Portuguesa, mas ainda de toda a Companhia, foi sem contestação o piedoso monarca D. João III. Rodrigues, Francisco S. J. História da Companhia de Jesus na Assistência de Portugal. Tomo I, Vol. II. Porto, Apostolado da Imprensa, - Empresa Editora, 1931, p. 587.

${ }^{44}$ P. Simonis Rodericii Monumenta. In Epistolae PP. Paschasii Broëti, Claudii Jaji, Joannis Codurii et Simonis Rodericii. Matriti, 1903, p.521.

${ }^{45}$ Ver Astrain, P. Antônio S. J. Santo Inácio de Loyola. Fundador da Companhia de Jesus (1491-1556. Porto, Biblioteca do Apostolado da Imprensa, 1927, p.80.
} 
lusitana. Teólogo conservador português, professor em Paris e diplomata, propôs em 1538 que D. João III “convidasse” a Companhia de Jesus para se estabelecer na Índia ${ }^{47}$.

O padre Francisco de Borja, futuro Vigário Geral e, antes de ingressar na Companhia de Jesus, Duque de Gândia, desempenhou um papel relevante nas cortes espanhola e portuguesa representando os interesses da Companhia. Coube-lhe a direção espiritual da princesa Joana, filha de Carlos V. Encontrava-se regularmente com a rainha (Joana), inclusive assistiu a sua morte, e era conselheiro de Carlos V. Foi para Portugal em 1557 a pedido do Imperador para tentar colocar seu neto, o príncipe Carlos, no trono português. Desempenhou a função de Comissário da Companhia de Jesus em Portugal, Aragão, Bética e Castela, de 1554 a $1561^{48}$. “... Com a grande autoridade que gozava junto do Imperador e do Rei de Portugal, foi verdadeiramente o anjo tutelar da Companhia na Península durante muitos anos” 49

Desde as suas origens, a Companhia de Jesus se aliou às classes privilegiadas da sociedade e da Igreja em Portugal. Esta aliança será um dos fatores responsáveis, no futuro, pela predominância do grupo conservador e elitista que excluiu dos seus quadros qualquer indivíduo que não provasse ter "sangue puro"

\footnotetext{
${ }^{46}$ P. Simonis Rodericii Monumenta. Idem. Carta enviada para Inácio de Loyola em Maio de 1541, p.524. Chma a atenção o fato de Simão Rodrigues ter residido na própria corte. Ver O’Malley, John W. Os Primeiros Jesuítas. São Leopoldo, Editora Unisinos, Bauru, Edusc, 2004, p. 234.

${ }^{47}$ Ver a respeito de Diogo de Gouveia, o velho, Enciclopédia Verbo Luso-Brasileira de Cultura, Edição Século XXI, 13. Lisboa, São Paulo, Editorial Verbo, 2000, pp.970-971. A palavra convidar está entre aspas porque, na realidade, Diogo de Gouveia sugeriu que o rei financiasse as missões jesuítas no Oriente.

${ }^{48}$ A Província espanhola foi criada em Setembro de 1547 (Castela), em 1553 a de Aragão e em 1554 a Província Bética (Espanha, atual Andaluzia). Sobre Francisco de Borja ver Diccionario Histórico de la Compañía de Jesus. Biográfico-Temático. Roma, Institutum Historicum, S. I. 2001 e Madrid, Universidade Pontifícia Comillas, 2001, Vol. II, pp. 1605-1611.

${ }^{49}$ Astrain, P. Antônio S. J. Op. cit., p.83.

${ }^{50}$ A presença da Companhia de Jesus na corte portuguesa, por exemplo, chegou a causar mal-estar na mesma: “... el mal odor que la Compañía tiene en esta corte por se entrometer mucho con príncipes y como el mismo Simón com celo avia desplazido á todos estes prícipes...”. In Epistolae Mixtae Tomus III. Matriti, 1900. Carta de Luiz Gonçalves da Câmara (por comissão de Miguel de Torres, Visitador) escrita em Janeiro de 1553 para Inácio de Loyola, p.38. Houve um momento em que, por exemplo, os confessores do rei, da rainha e do cardeal eram todos jesuítas. P. Miguel de Torres confessor de D. Catarina, Leão Henrique do Cardeal e Luís da Câmara confessor do rei. Ver Margues, João Francisco. Os Jesuítas, Confessores da Corte Portuguesa na Época Barroca (1550-1700). Porto, separata da Revista da Faculdade de Letras, II Série, Vol.XII, p.248.
} 
Na sétima parte das Constituições da Companhia de Jesus encontra-se uma norma, inclusive justificada e aprovada pela Assembléia Geral de 1558, baseada no seguinte raciocínio: quanto mais universal é o bem, mais divino ele se torna. Em outras palavras, a intensidade e a extensão da presença do divino estava condicionada à capacidade de alcance do bem praticado: "Por este mesmo motivo do bem universal, deve ter-se como mais importante o auxílio espiritual aos homens de influência, ou que exercem funções públicas (quer sejam leigos, como príncipes, senhores, magistrados, e juízes, quer sejam eclesiásticos, como os prelados), bem como a pessoas eminentes pelo saber e autoridade" ${ }^{51}$.

Assim pensando, os jesuítas aliaram-se às classes dominantes buscando o apoio necessário à difusão dos ideais inacianos. Esta adesão aos poderes dominantes, seja político, religioso ou cultural é um dado relevante porque esclarecerá as opções políticas que a Companhia de Jesus fez, principalmente no que se refere aos cristãos novos, tanto de origem judaica quanto moura ${ }^{52}$.

\section{CRITÉRIOS DE SELEÇÃO}

No caso das pessoas a serem escolhidas para ingressar na Companhia de Jesus havia critérios também elitistas e excludentes. Os candidatos deveriam ser influentes ou possuir autoridade. O fundamento para utilizar tais critérios era o mesmo que justificou o auxílio espiritual às elites: o bem seria mais divino quanto mais universal fosse. Portanto, na concepção dos jesuítas, as pessoas influentes e

\footnotetext{
${ }^{51}$, Constituições da Companhia de Jesus e Normas Complementares. São Paulo, Edições Loyola, 1997, Sétima Parte, p.195

${ }^{52}$ Ver a esse respeito o artigo de Margues, João Francisco. Idem, onde ele diz, entre outras coisas, que “ $a$ partir de 1540, os reis portugueses entregaram, na verdade, ao longo de duzentos anos, a sua consciência aos jesuútas, que a dirigiram em momentos cruciais da vida política nacional,” p.234, 1995. Do mesmo modo que a Companhia influenciava na vida política, ela também se submetia à vontade política da Corte, da qual dependia em vários aspectos. Cabia ao Rei decidir, por exemplo, se os cristãos novos deviam ou não ingressar na Companhia: "De los que dependen (descienden) de xpianos. Nuevos, si el rey no quiere se admittan, ó no para su reyno determinadamente, hágase lo que a S. A. pareçerá”. Monumenta Ignagtiana, Series Prima, Epistolae et Instructiones, Tomus Octavus, Matriti, 1909, p.446.
} 
que possuíssem autoridade, graças a estas características, teriam os meios mais apropriados para levar o "bem” a um número maior de indivíduos, tornando-o mais universal e, portanto, mais divino: "Sendo o bem tanto mais divino quanto mais universal, devem-se preferir as pessoas e os lugares cujo aproveitamento possa ser causa de que o bem se estenda a muitos outros sob a sua influência ou autoridade

Percebe-se, muito claramente, que o método escolhido pela Companhia de Jesus para “conquistar o mundo” e "salvar a alma dos jesuítas” foi a difusão dos seus ideais através do apoio de indivíduos privilegiados, do alto clero católico, instituições de grande poder politico, econômico e social, como as cortes européias, especialmente a Espanhola e Portuguesa.

Ainda nos seus primórdios, em 1541, a Companhia de Jesus já havia estabelecido dois critérios de exclusão de candidatos. O primeiro era de natureza religiosa. Proibiu receber todos que foram julgados e condenados por heresia: "Quem tem sido julgado e condenado por juízo de heresia não se receba 54 . $\mathrm{O}$ segundo era de ordem estética. Estava proibido admitir quem portasse defeitos físicos, a não ser que fossem muito bons, excelentes: "Se não for por excelência; notavelmente defeituoso, coxo ou torto, etc., não se receba." ${ }^{55}$.

Apesar dos propósitos universalistas da Companhia de Jesus, de pretender, junto com Cristo, amar até mesmo os próprios inimigos, com o transcorrer do tempo suas intenções iniciais se desvirtuaram. Os critérios de seleção dos irmãos eram excludentes e intolerantes. Discriminou os condenados por heresia e os deficientes físicos e acrescentaram ainda, cinco anos mais tarde (1546), sete impedimentos para admitir os postulantes, vejamos:

\footnotetext{
${ }^{53}$ Constituições da Companhia de Jesus e Normas Complementares. Op. cit., p.195.

54 Monumenta Ignatiana. Séries Tertia, Constitutiones Societatis Jesu. Tomus Primus, Monumenta Constitutionum Praevia. Roma, 1934. Org. A. Codina. Constitutiones Anni 1541, p.39.

55 Idem, p.40.
} 
I) “O primeiro impedimento é se algum dos tais, deixando nossa religião cristã, tem sido entre infiéis renegado;”

II) "Se algum tem sido reprovado em alguma proposição herética por sentença pública;”

III) "Se algum tem sido infame excomungado, depreciando a providência da nossa santa Igreja, sendo regida e governada por Espírito Santo;”

IV) "Se algum tem sido por algum tempo homicida;"

V) "Se algum foi infame por pecados enormes;"

VI) "Se algum tomou hábito de religião de freis ou clérigos, vivendo algum tempo com eles em obediência, tendo feito profissão ou não tendo feito;”

VII) "Se algum tem sido ermitão com vestidos monacais." ${ }^{\text {. }}$.

Depois dos impedimentos vigorarem por aproximadamente um ano, a Companhia de Jesus necessitou enfatizar a necessidade do seu uso: "Nos sete impedimentos não se ponha exceção nem declaração."57 Por que a necessidade desse rigor? Ou por não estar sendo aplicado por todos ou por ter sofrido alguma contestação. É muito provável que, em ambos os casos, determinados jesuítas entendessem que havia algo de contraproducentes nos impedimentos.

Esta hipótese é procedente porque no ano de 1548 todos os impedimentos foram praticamente anulados. Ficou sob a responsabilidade dos professos

\footnotetext{
${ }^{56}$ Monumenta Ignatiana, Series Tertia, Sancti Ignatii de Loyola, Constitutiones Societatis Jesu, Tomus Secundus, Textus Hispanus, Roma, 1936. Examen Cum Declarationibus, Textus a. ca. 1546. Examen General en el Qual se Contiene Primero Siete Impedimientos Para Todos, Letrados, Coadiutores Spirituales, Coadiutores Temporales, o Escolares, que Desean Entrar en Esta Compañía de Jesú Nuestro Criador y Señor, pp. 20-24. Os mesmos impedimentos encontram-se em outro texto escrito no mesmo ano (1546) denominado "Impedimenta Quaedam". In Monumenta Ignatiana, Ex Autographis Vel Antiquioribus Exemplis Collecta. Series Tertia. Sancti Ignatii de Loyola. Constitutiones Societatis Jesu. Tomus Primus. Monumenta Constitutionum Praevia. Roma, 1934, Suffragium Quatuor Sociorum, p.245.

Roma, 1934, p.180.
} 
estabelecer os critérios para selecionar os candidatos que já estavam em processo de seleção. Ou seja, os sete impedimentos seriam aplicados aos futuros inscritos. Mesmo assim, tais restrições não são suficientes para impedir que se reconheça uma nova atitude dos jesuítas. A Companhia de Jesus parecia estar retornando aos seus primórdios de tolerância e universalismo presentes nos Exercícios Espirituais de Inácio de Loyola: “... que cada uno de los que siguen al presente la Compañía, aunque teniendo algún impedimento para entrar en ella, se pueden reçibir, si ninguno de los professos no fuere de contrario parecer. Esto se entiende de lo[s] que se hallaren hasta oy dia, no de otros que para adelante se offreçiesen."58.

Entretanto, um novo documento foi composto e recolocou em vigor os impedimentos. Nele se lê que não devia existir nenhuma exceção em sua aplicação. A intransigência se justificava porque glorificava a Deus: "Cerca los 7 impidimentos, letra $b$, nos há parecido en el Señor nuestro que no debemos más en aumento declararlos, ni poner en ellos excepción alguna, porque mejor y más enteramente se puedan guardar en mayor seuitio y gloria divina." 59 .

Mas o embate entre estas duas visões políticas no interior da Companhia de Jesus não estava esgotado. O grupo "tolerante" e progressista conseguiu reverter a situação. Para ser aceito, o candidato com impedimento deveria possuir alguma qualidade considerada excepcional e, com isso, solicitar ao Papa o seu ingresso na Companhia. Em outras palavras, foi delegado ao Sumo Pontífice ou ao seu representante (o núncio), a partir de 1550, o poder de ignorar os impedimentos e assim permitir o ingresso daqueles que estariam excluídos. Após a aprovação papal, o Superior Geral poderia dar o consentimento:

\footnotetext{
${ }^{57}$ Idem, Indice Rerum Anonymi,1547-49(?), p.237.

${ }^{58}$ Monumenta Ignatiana, Ex Autographis Vel Antiquioribus Exemplis Collecta. Series Tertia. Sancti Ignatii de Loyola. Constitutiones Societatis Jesu. Tomus Primus. Monumenta Constitutionum Praevia. Op. cit., Suffragium Quatuor Sociorum, p.245.

${ }^{59}$ Idem, Declarationes in Examen 1548-49 (?). Declarationes sobre Algunos Lugares del Examen de los que Desean Entrar en la Compañía de Jesú Nuestro Criador y Señor, p.250.
} 
"En los 10 impedimentos, es bien que ni el general 'ni toda’ la Compañía pueda dispensar, porque universalmente conviene a la Compañía 'que no se dispense en los tales'; pero cuando se viese ayer algún impedimento destos en algún particular, que tuviese tales partes que se juzgase podría la Compañía en servicio de Dios N. S. mucho ayudarse del, cuándo el tal hiciese suplicar al papa 'que concediese que' no obstante las Constituciones, pudiese ser admitido, no repugnando el prepósito general, o lo mismo alcanzase de los nuncios de su santidad o del penitenciario sumo; poderla dar consentimiento el prepósito general 'pareciéndole ser a mayor gloria divina', con que no se abriese la puerta para muchos ni para ninguno sin partes muy raras”60.

Este procedimento foi mantido nas Constituições aprovadas na primeira Congregação Geral da Companhia de Jesus realizada em 1558. Houve algumas modificações no conteúdo dos impedimentos, sem contudo alterar sua essência ${ }^{61}$.

Quanto aos critérios para o ingresso, é interessante observar que, apesar das restrições existentes, os candidatos que possuíam alguma "qualidade excepcional" poderiam ser aceitos, mesmo tendo algum impedimento. Entretanto, está bem claro que todos os candidatos que não possuíssem algum talento não seriam aceitos pela Ordem.

Com a adoção de medidas restritivas e excludentes de seleção dos postulantes, a Companhia de Jesus tornou-se gradativamente uma Ordem seletiva e elitista. Tanto em seus critérios de seleção quanto na propagação do "bem universal”, foi uma Ordem discriminadora.

\footnotetext{
${ }^{60}$ Monumenta Ignatiana. Ex Autographis Vel Antiquioribus Exemplis Colecta. Series Terria. Sancti Ignatii de Loyola. Constitutiones Societatis Jesus. Tomus Secundus. Textus Hispanus. Roma, 1936, p.288.

${ }^{61}$ Ver Constituições da Companhia de Jesus e Normas Complementares. Op. cit., Capítulo III, Impedimentos para a Admissão na Companhia, pp.80-84.
} 
Para fazer parte da Companhia de Jesus era necessário atender a préreguisitos que somente uma parcela muito restrita da sociedade seria capaz de preencher. Um desses pré-reguisitos incluía "influência ou autoridade".

Com seu programa excludente, a Companhia de Jesus privilegiou as elites políticas, religiosas e econômicas da sociedade. Os jesuítas eram oriundos dos estratos sociais mais elevados. Também por este motivo, seus bens espirituais eram ofertados, em primeiro lugar, para os mesmos estratos dos quais ela se constituía.

Os bens espirituais que a Companhia de Jesus oferecia aos setores dominantes da sociedade demonstraram ser muito eficazes. Ao recebê-los, as elites afirmaram e legitimaram a presença da Ordem entre as classes dominantes, o que resultou na afirmação, legitimação e prestígio cada vez maiores da Companhia de Jesus.

A Companhia de Jesus tornou-se uma Ordem considerável, com enorme influência para a história da Igreja Católica, para a cultura européia e para a história das colônias espanholas e portuguesas.

No interior deste amplo projeto espiritual, com significativas implicações políticas, culturais e sociais, insere-se uma problemática das mais sérias consequências: a questão dos cristãos novos na Companhia de Jesus. 


\section{CAPÍTULO III. A PROBLEMÁTICA DOS CONVERSOS NA COMPANHIA DE JESUS DURANTE AS PRIMEIRAS DÉCADAS DE SEU FUNCIONAMENTO}

No seu aspecto normativo, o problema dos cristãos novos na Companhia de Jesus se manifestou, inicialmente, nos textos preparatórios das Constituições, nos Regimentos dos Colégios jesuítas e nas Constituições aprovadas em 1558.

É importante notar que nos primeiros documentos normativos da Companhia de Jesus, redigidos em $1540^{62}$ e $1541^{63}$, não aparece nenhuma referência à questão dos judeus e seus descendentes. Esse silêncio pode sugerir algo muito significativo. Diego Laínez, de origem judaica, fazia parte do grupo dos fundadores da Ordem desde os tempos em que cursou teologia em Paris (1532-36). Quando estavam sendo elaboradas as primeiras normas, Juan de Polanco, também de origem judaica, ingressou na Companhia de Jesus. Além dele, foi recebido no mesmo período Afonso Álvaro, cristão novo português, admitido por Pedro Favre entre 1540-41 ${ }^{64}$.

A ausência de referência aos cristãos novos nas regras de 1540 e 1541 pode estar ligada ao fato de a origem judaica não ser ainda um problema para a Companhia de Jesus. E mesmo que tivesse surgido entre os jesuítas cristãos velhos alguma objeção ao ingresso dos conversos, não foi possível, sequer, inserir o problema nas normas de 1540 e 1541.

\footnotetext{
${ }^{62}$ Ver Intiquissimae Scholasticorum Regulae, 1540. In Monumenta Ignatiana, Series Tertia, Constitutiones et Regulae Societatis Iesu, Volumen 4, Regulae Societatis Iesu (1540-54). Edidit Dionysius Fernández Zapico S. I. Romae, 1948, pp.4, 6, 8 e 10.

${ }^{63}$ Ver Monumenta Ignatiana. Séries Tertia, Constitutiones Societatis Jesu. Tomus Primus, Monumenta Constitutionum Praevia. Roma, 1934. Org. A. Codina. Constitutiones Anni 1541, pp.39-40.

${ }^{64}$ Ver P. Simonis Rodericii Monumenta. Op.cit., pp. 588-89.
} 


\section{A EXCLUSÃO DOS CRISTÃOS NOVOS DO COLÉGIO DE COIMBRA}

Entretanto, transcorridos cerca de três anos, o padre Simão Rodrigues proibiu a entrada de cristãos novos no Colégio da Companhia de Jesus em Coimbra. Ele também não assinou as normas de 1541. Talvez por não concordar com o conteúdo que não fazia nenhuma menção aos conversos.

Em Janeiro de 1543 Simão Rodrigues escreveu para Inácio de Loyola pedindo que lhe enviasse as “Constituições” (normas de 1541). Mas não estava disposto a colocá-las em prática imediatamente. Pretendia protelá-las: “Manda-me as constituições que tens feitas, e não creio que seja mal esperar alguns dias sem as confirmar, porque o tempo muitas vezes e com o tempo Deus N. S. ensina seus servos." ${ }^{65}$.

Simão Rodrigues, com certeza, já estava ciente do conteúdo das normas redigidas em 1541. Mesmo assim, ele compôs as Regras do Colégio de Coimbra. Evidente que podia haver contradição entre as normas e as regras do Colégio de Coimbra. Talvez prevendo isso, ou certo disso, ele assumiu o que estava fazendo: “... eu não hei de deixar o que pensarei ser glória de meu Deus ${ }^{66}$. Neste ínterim Diego Mirão, reitor do Colégio da Companhia de Jesus em Coimbra, deixou o cargo e dirigiu-se para Valência, onde com mais três jesuítas fundou o Colégio São Paulo. Em 1552 sucedeu Simão Rodrigues no cargo de Provincial português ${ }^{67}$.

Não encontramos nenhum documento que apontasse qualquer relação entre o regimento do Colégio de Coimbra e a saída de Diogo Mirão da reitoria. Apesar disso, a hipótese de Diogo Mirão ter se retirado por não concordar com o Regimento não está totalmente descartada, uma vez que contrariava as normas de 1541.

O Regimento do Colégio dos jesuítas de Coimbra, fundado por Simão Rodrigues, é um documento de suma importância para a história dos cristãos novos

\footnotetext{
${ }^{65}$ P. Simonis Rodericii Monumenta. Op. cit., pp. 531-32.

${ }^{66}$ P. Simonis Rodericii Monumenta. Idem, p. 532.

${ }^{67}$ Diogo Mirão exerceu o provincialato em Portugal em duas oportunidades. A primeira entre $1552-55$ e a segunda de 1563-65. Foi visitador na Província portuguesa nos anos 1571-72. Ver O’Neill, Charles E., S. I. e Domínguez, Joaquín Ma , S. I. Op. cit., Vol.III, p.2686.
} 
na Companhia de Jesus, porque se trata do primeiro texto normativo escrito por um jesuíta que discriminou os descendentes de judeus. Em Janeiro de 1543 estava pronto o regimento:

“As coisas de Coimbra vão tanto adiante, que por mais que eu as escreva, não as crereis. O tempo que lá estive, escrevi toda a ordem da casa e regimento, e regras para todos os oficiais que se podem ter, e acabei um grande cuidado por graça de Deus. Alegrará de pode-lo mandar, por[que] o concordardes e aprovardes para mais meu contentamento; e creio que para qualquer colégio da Espanha pode servir. ${ }^{\circ 68}$.

A intolerância das regras do Colégio da Companhia de Jesus de Coimbra para com os cristãos novos foi absoluta. Os descendentes dos judeus estavam proibidos de estudar no Colégio:

"Os que por inspiração divina pedirem ser recebidos no colégio, para no instituto da Companhia servirem a seu Deus e senhor, serão examinados das coisas seguintes; e se em alguma delas forem compreendidos, não se receberão; e se o negarem, em todo tempo que se souber, serão lançados fora (....)" "Se por alguma via descende de cristãos novos $^{\text {"69 }}$ (grifo nosso).

Por que Simão Rodrigues tomou esta atitude? Qual foi a reação da Companhia de Jesus a esse respeito?

${ }^{68}$ P. Simonis Rodericii Monumenta. Op.cit., p.539. 
A documentação consultada não responde diretamente a estas questões. Entretanto, é possível levantar algumas hipóteses a partir de alguns fatos que podem responder ambas as perguntas.

Simão Rodrigues, de família nobre, estudou no Colégio Santa Bárbara, em Paris, como bolsista da Coroa portuguesa ${ }^{70}$. O diretor do colégio era o teólogo, também português, Diogo de Gouveia, o velho. Foi ele quem sugeriu a D. João III que enviasse jesuítas para missões no Oriente. O rei, atendendo à indicação de Diogo de Gouveia, encarregou o seu embaixador em Roma, D. Pedro de Mascarenhas, para por em prática a sugestão de Diogo de Gouveia.

Foram escolhidos dois companheiros de Inácio de Loyola, Simão Rodrigues e Francisco Xavier. Este partiu para o Oriente em $1541^{71}$, mas Simão Rodrigues permaneceu em Portugal.

Ocorre que Diogo de Gouveia era um teólogo “intransigente da ortodoxia católica tradicional”" $^{\text {"2 }}$ Foi influente na Corte, inclusive com acesso ao rei e era líder da “ortodoxia católica tradicional portuguesa”, com grande influência política em Coimbra.

Simão Rodrigues, talvez atendendo às exigências da ortodoxia católica coimbrã, ou pensando em não contrariá-la, proibiu o acesso dos cristãos novos ao "Colégio de Jesus." Além disso, o regimento, ao excluir os conversos, estava coerente com a mentalidade anti-semita de Diogo de Gouveia.

\footnotetext{
${ }^{69}$ P. Simonis Rodericii Monumenta. Idem. P.Simonis Rodericii Regulae de Collegus Societatis Jesu. Modo que ha-de ter nos Collegios da Companhia en o Reçeber dos Estudantes d'Ella, p.861.

${ }^{70}$ Simão Rodrigues, português, um dos fundadores da Companhia de Jesus. Foi o primeiro Provincial da Companhia em Portugal, fundou o Colégio de Coimbra e redigiu o seu regimento, participou da fundação do Colégio de Évora (Colégio Espírito Santo), e a partir de 1545 foi o preceptor do infante D. João. Ver O’Neill, Charles E., S. I. e Domínguez, Joaquín Ma, S. I. Diccionario Op., cit., Vol.IV. pp. 3390-92. E foi ainda o confessor de D. João III. Ver O’Malley, John W. Op. cit., p. 234.

71 Francisco Xavier viajou com mais dois "companheiros" (Paulo Camerte e Francisco Mansilhas), financiados pelo Rei D. Joâo III: "My Hermano Mtro. Francisco se partió de aquí con dos compañeros á los siete d'Abril del anno presemte de 1541, muy faborecido de rey, e ayudado muy liberalmente pera la mar, y más de los él quisiera, por asy querer el rey, á quien aquí prestamos obediemtia.” P. Simonis Rodericii Monumenta. Op. cit., p.521.

${ }^{72}$ Enciclopédia Verbo Luso-Brasileira de Cultura, Edição Século XXI, 13. Lisboa, São Paulo, Editorial Verbo, 2000, p.971.
} 
Ocorre que em 1547 houve problemas, e graves, no colégio de Coimbra, que inclusive comprometeram os estudos. Alguns alunos - não sabemos quantos nem seus nomes - não estavam satisfeitos no Colégio. Qual o motivo da “rebelião estudantil”? A documentação consultada não responde. Mas a reação do seu fundador e autor das regras, Simão Rodrigues, foi enérgica: os expulsou. Com isso, segundo ele, os alunos silenciaram, os estudos se normalizaram, e tudo voltou ao normal: “Agora se estuda tão bem ou melhor que nunca, e estão muito quietos, graças a Deus. Expulsei os inquietadores, como o P. Sancta Cruz dirá, e tudo está bem"73.

Como as regras já estavam em vigor, é plausível supor que os alunos “inquietadores” discordassem das mesmas ${ }^{74}$. Também é razoável a hipótese de que os estudantes expulsos fossem cristãos novos. Inclusive, como veremos a seguir, o próprio rei estava preocupado com a possível presença de conversos entre os jesuítas de Coimbra.

Ninguém da Companhia de Jesus se manifestou contra o Regimento. Ou melhor, não se conhece nenhum documento que demonstre, explicitamente, a reprovação feita por alguém da Ordem. Contudo, Simão Rodrigues recebeu o apoio do jesuíta espanhol António Araoz, primeiro provincial da Companhia na Espanha $(1547)^{75}$ e parente de Inácio de Loyola ${ }^{76}$.

\footnotetext{
${ }^{73}$ P. Simonis Rodericii Monumenta. Op.cit., p.562 (Carta enviado para o Geral, Inácio de Loyola, em 29.06.1547).

${ }^{74}$ Em 14 de Janeiro de 1548 Inácio de Loyola redigiu uma carta para o reitor e estudantes do Colégio de Coimbra, cujo tema foi a obediência, a qual foi por ele assim concebida: "la verdadeira obediencia no subiecta al superior solamente las obras, pero aun las vontades; y no solo las voluntades, pero aun los pareceres; y entonces la unión se haze firme y durable, y la paz y quietude en este santo y suave iugo, en un certo modo (quanto el estado presente y mísero compadece) imperturbable.” In Monumenta Igantiana, Séries Prima, Epistolae et Instructiones. Tomus Primus. Matriti, 1903, p. 690. Na página anterior, ou seja, 689, Inácio de Loyola se referiu a um caso prático de obediência, a do reitor em relação ao Provincial: "axial como el mesmo rector igualmente con los demás devrá estar en todo subjecto al prepósito provincial, en especial aviendo Dios N. S. usado dél como de instrumento para principiar esta su obra; y él assimimso [lo será] á quienquiera que Dios N. S. le diere por superior general”. Portanto, desobedecer ao superior geral significava desobedecer àquele que Deus escolheu para a referida função. Sendo assim, quem não obedecesse ao Geral, indiretamente estaria desobedecendo ao próprio Deus. Ao ter se referido à obediência de todos em relação ao Geral da Companhia, Inácio de Loyola poderia está dando uma advertência ao seu Provincial em Portugal, Simão Rodrigues que, ao provavelmente, insistia em manter a exclusão dos cristãos novos no regimento do Colégio de Coimbra.

${ }^{75}$ P. Simonis Rodericii Monumenta. Op. cit, prefácio de Federico Cervós, p.447.
} 
Este silêncio e esta ausência possuem algum significado? Seria conveniente para a Companhia fazer vistas grossas ao anti-semitismo presente no regimento do “Colégio de Jesus”? É muito provável que sim. Mais uma vez, a análise será feita através de correlações.

Coimbra era um lugar de destaque na cultura portuguesa ${ }^{77}$. A Companhia de Jesus deveria saber que um colégio naquela cidade desempenharia um papel determinante no futuro da Ordem em Portugal. Talvez por isso, os jesuítas não pareciam estar dispostos a entrar em conflito com a nobreza e com a ortodoxia católica locais.

\section{A POSTURA DE INÁCIO DE LOYOLA}

O posicionamento de Inácio de Loyola a respeito das regras do Colégio de Jesus foi diferente do adotado por Simão Rodrigues. Quando foi solicitado pelo Provincial de Portugal para elaborar as regras daquele colégio, que ele considerou necessárias para resolver a "anarquia” que nele predominava, Inácio de Loyola simplesmente não atendeu à solicitação de Simão Rodrigues. Ou seja, segundo o Provincial, seria da competência de Inácio de Loyola elaborar as Regras. Mas ao mesmo tempo, Simão Rodrigues afirmou que quando Inácio de Loyola enviasse as Regras definitivas, elas seriam avaliadas em Coimbra. Ou seja, a decisão final sobre o conteúdo das Regras competiria a Simão Rodrigues. O provincial português se auto elegeu como a autoridade máxima em relação às normas do colégio por ele fundado ${ }^{78}$.

\footnotetext{
${ }^{76}$ O’Malley, John W. Op. cit., p.62.

${ }^{77}$ A primeira Universidade portuguesa foi instalada no ano de 1308 em Coimbra. Ficou conhecida como Universidade de Coimbra, apesar de ter ido duas vezes para Lisboa (1338 e 1377). Em 1537 foi transferida definitivamente para Coimbra.

${ }^{78}$ Extrato da ccarta do Padre Simão Rodrigues enviada para o padre Matim Santa Cruz, em 13 de Agosto de 1546 onde se encontra a solicitação feita pelo Provincial ao Geral da Companhia: "P. misser Ignacio, occupado em cousas de maior qualidade e, segundo eu imagino, por não saber enteiramente o que cá passa, não nos acode com o que nos he necessário, avendo-lhe eu por vezes escrito que nos mandasse regras, pollas quaes nos regêssemos conforme a nosso instituto, e nunca me respondeo a isso. E vendo que a necessidade que tínhamos de não viver confusamente e cada hum segundo seu parecer, fiz esses apontamentos adiante escritos, que comprehendem a substancia do que a mi pareceo que nos convinha; e mando-os para que os
} 
Inácio de Loyola "lavou as mãos”. Delegou implicitamente a Simão Rodrigues o poder de compor as Regras do Colégio. Com isso o Geral e fundador da Companhia de Jesus, Inácio de Loyola, evitou que a Ordem como um todo se comprometesse com os setores intolerantes da sociedade coimbrã. Resistiu às pressões $^{79}$. Mas permitiu que Simão Rodrigues impedisse o ingresso dos cristãos novos.

O regimento escrito por Simão Rodrigues foi aplicado e é provável que tenha continuado em vigor mesmo após a aprovação das Constituições da Companhia de Jesus $(1558)^{80}$.

\section{O ANTI-SEMITISMO DE COIMBRA}

Através do regimento do Colégio da Companhia de Jesus de Coimbra compreendemos algumas questões em ralação aos cristãos novos: constituíam um grave problema para a sociedade coimbrã; a Companhia de Jesus agravou ainda

façaes escrever no livro que tem a regra do collegio. E quando os de Roma mandarem outras regras, conformar-nos-emos com elles, pois são mais, e a quem o Spirito Sancto inspira o que nos convem; que de mi posso dizer: in maleuolam animam non introit sapientia. E quando elles mandarem seu parecer, se alguma d'estas regras nos parecer ncessária, então lh'o escreveremos, e alegaremos as razões que nos bem parecer etc.” In Simonis Rodericii Monumenta. Op. Cit., pp.546-47.

${ }^{79}$ Inclusive, a posição do Bispo de Coimbra, João Soares, foi ambígua em ralação à presença de cristãos novos na Companhia. Isso deixou Inácio de Loyola mais à vontade para não redigir regras excluindo os conversos do Colégio de Jesus. Ver nota seguinte.

${ }^{80}$ Houve um grave problema na Província portuguesa neste período. Surgiram dois grupos. Um favorável a Simão Rodrigues e outro a Inácio de Loyola. Ou seja, dois grandes nomes da Companhia de Jesus estavam em conflito, ambos fundadores da Ordem. Miguel de Torres, como visitador em Portugal, registrou este acontecimento em Janeiro de 1553, mas sem apontar as causas do conflito: "Digo que la differençia entre los de Simón y los del P. Ignacio es tan mala dentender...”. In Epistolae Mixtae Tomus III. Matriti, 1900, p.47. Simão Rodrigues foi demitido do cargo de Provincial em 1552. Inclusive Inácio de Loyola pediu ao monarca (D. João III) para demiti-lo. Ver Epistolae Mixtae. Idem, pp. 99 - 100). Além dele foram dispensados "mais da metade dos que faziam os exercícios, os de sete a oito anos de Teologia e formados mais de doze. In Epistolae Mixtae.Idem. Carta de D. Theotonio para Francisco de Borja (08. 03. 1553), p. 140. A ordem para a dispensa foi dada por Inácio de Loyola a Diogo Mirão (Provincial). Ver Epistolae Mixtae. Idem, p. 157. Entretanto, no Dicionário Histórico da la Compañía de Jesus, o conflito de Simão Rodrigues teve como pivô Luís Gonçalves da Câmara, que junto com Melchior Carneiro, teriam liderado o grupo que fazia oposição a Simão Rodrigues. Luís Gonçalves da Câmara foi nomeado reitor o Colégio de Jesus (em Coimbra) em 1547. Mas em Agosto de 1548 foi para a Etiópia. Quando retornou para Portugal partiu logo para Roma (1553). Ou seja, perdeu o reitorado do Colégio de Jesus. Ver O’Neill, Charles E., S. I. e Domínguez, Joaquín Maa S. I. Op., cit., Vol. I, p. 608. O que a documentação não diz é que o afastamento de Simão Rodrigues do provincialato em Portugal pode ter sido causado, também, pelo impedimento aos cristãos novos de ingressarem no Colégio de Coimbra. Já que este item do regimento, redigido por Simão Rodrigues, contrariava as "Constituições." 
mais sua situação ao impedir o ingresso no colégio jesuíta. É certeza que grassava um anti-semitismo exacerbado em Coimbra.

Em uma carta escrita pelo rei D. João III, em Agosto de 1555, para o bispo de Coimbra, podemos compreender a intolerância que reinava na cidade de Coimbra contra os cristãos novos. O rei procurou se informar se a Companhia de Jesus recebia pessoas "infames”. O bispo respondeu a carta do monarca dizendo que não sabia quem the havia transmitido essa informação, dando a entender que desconhecia os tais “infames”. Segundo o Apóstolo Paulo, dizia o bispo, não havia distinção entre judeu e grego. Mas não deixou de reconhecer as limitações dos cristãos novos para serem bons cristãos. Afirmou não saber se a Companhia os havia recebido e assumiu o discurso intolerante predominante em Coimbra ao dizer que os jesuítas que ele conhecia eram "nobres, e filhos de gente honrada e limpa"81.

Foi dúbia a posição do bispo João Soares. De um lado, negava o conceito de infame, do outro, classificou os jesuítas que conhecia como "nobres, e filhos de gente honrada e limpa" (grifo nosso). Por um lado fez a defesa dos cristãos novos demonstrando que eles tinham méritos, por outro, assumiu o discurso anti-semita. Vivia dividido entre a tolerância e as limitações de onde provinha, isto é, a intolerância presente em Coimbra.

\section{A DUBIEDADE DE SIMÃO RODRIGUES}

É curioso que o próprio Simão Rodrigues, autor do Regimento anti-semita do Colégio da Companhia de Jesus de Coimbra, tenha admitido cristãos novos na Companhia de Jesus. Henrique Henriques, por exemplo, ingressou na Ordem ajudado e apoiado por Rodrigues, inclusive no mesmo período em que foi escrito o regimento do Colégio:

\footnotetext{
${ }^{81}$ Ver a pergunta de D. João III e a resposta do Bispo João Soares, na íntegra, na Monumenta Ignatiana, Series Prima, Epistolae et Instructiones, Tomus Duodecimus. Matrite, 1911, p.587
} 
“ (...) o outro, que é Henrique Henriquez, quando o tomei, se bem me lembro, o tomei não para ser da Companhia, senão por ele ser quem vós sabeis quem ele é, e o suster assim, e o mandar a Índia, como mandei, para que Mtre. Francisco o pusesse em um lugar de infiéis; porque é ele de muita confiança (grifo nosso), poderia muito servir a nosso Senhor, o que tudo, se bem me lembro, escrevi a Mtre. Francisco; e as coisas lá havidas soão de uma maneira, e as intenções ficam no coração, e nos se entendem" ${ }^{\prime 2}$.

Henrique Henriques foi eleito superior regional na Pescaria (Costa da Pescaria, pertencente à Província de Goa), apesar do jesuíta António Gomes ter sido contra sua eleição alegando a sua ascendência judaica. Entretanto, ocupou o cargo entre $1549-76^{83}$.

\section{NORMAS DISCRIMINATÓRIAS}

A Companhia de Jesus inseriu no exame de 1546 uma pergunta nova que discriminava os cristãos novos. Foi a primeira vez que encontramos na Ordem uma discriminação oficial. Como não aparece nenhuma indicação específica, cremos que o exame deveria ser uma norma geral.

Existiam sete impedimentos para o ingresso na Companhia de Jesus. Caso o candidato não tivesse nenhum dos sete impedimentos, o exame poderia continuar. Havia entre as perguntas do processo de seleção uma referente aos cristãos novos: "Se vem de cristãos velhos ou novos e como"84.

\footnotetext{
${ }^{82}$ Simonis Rodericii Monumenta. Op.cit., p. 582 (carta escrita para o padre Martim Santa Cruz em 20 de Janeiro de 1548.

${ }^{83}$ Sobre Henrique Henriques ver Charles E. S.I. e Domínguez, Joaquín M. a, S.I. Op. cit., vol. I, pp.177-78.

${ }^{84}$ Monumenta Ignatiana, Series Tertia, Sancti Inatii de Loyola, Constitutiones Societatis Jesu, Tomus Secundus, Textus Hispanus. Roma, !936, Examen Cum Declarationibus, Textus a, CA, 1546, p.30.
} 
Entre os sete impedimentos não havia nenhum excluindo os cristãos novos. $\mathrm{O}$ que não impediu a dificuldade de acesso dos mesmos à nova Ordem. Pois sendo cristão novo o postulante perdia pontos para seus concorrentes diretos, os cristãos velhos.

Qual a razão da Companhia de Jesus, a partir de 1546, discriminar os cristãos novos? O “Examen Cum Declarationibus” não esclarece os motivos pelos quais foi incluída a pergunta sobre a origem dos candidatos. Como vimos, não correspondia aos propósitos de Inácio de Loyola, contidos nos Exercícios Espirituais. Mas se aproximava muito da intolerância constante do regimento do Colégio da Companhia de Jesus em Coimbra.

É razoável supor que a Companhia de Jesus se aproximou da política discriminadora utilizada pelo padre Simão Rodrigues em Coimbra. Entre agradar a nobreza e a ortodoxia católica tradicionais, e tratar cristãos novos e velhos com condições de igualdade, ela preferiu optar pela discriminação.

O anti-semitismo que constava do "Examen Cum Declarationibus" não era tão radical quanto o do regimento do Colégio da Companhia de Jesus de Coimbra, pois não excluía os candidatos cristãos novos, como fez o Regimento de Coimbra, mas, como já foi salientado, dificultava o ingresso dos descendestes dos judeus em todos os lugares onde a Companhia de Jesus existisse, enquanto que o regimento de Simão Rodrigues foi escrito especificamente para o colégio de Coimbra.

A questão dos cristãos novos voltou a ser levantada no mesmo ano em que foi redigido o "Examen Cum Declarationibus" (1546). Não de modo direto, claro e explícito, mas implícito, indireto e dissimulado. Entretanto, seu conteúdo foi o mais intolerante com os cristãos novos escrito até àquele momento. O documento diz o seguinte:

“"Nenhum que tiver algum impedimento dos que se seguem, se receba para Companhia nem para coadjutor, é a saber' se for homicida ou entre infiéis renegado, ou infame (grifo nosso), excomungado ou 
reprovado por sentença de alguma proposição herética, ou se esteve em alguma religião professo ou não professo; ou se foi eremita sob hábito monacal",85.

Quem seria infame? Por que distinguir o infiel, o homicida, excomungado, herege, etc., do infame? O infame somente poderia ser o cristão novo. Como será visto posteriormente, são várias as fontes, inclusive escritas pelos jesuítas, que fazem alusão à “infâmia” dos cristãos novos.

Os jesuítas, com a cumplicidade da nobreza, deram assim outro passo para dificultar ainda mais o ingresso dos cristãos novos na Companhia de Jesus. Em um outro documento (Declarationes in Examen), escrito cerca de dois anos mais tarde 1548-49), a discriminação contra os cristãos novos reapareceu, mesmo que indiretamente, quando estabeleceu como critério de seleção a “fama” e ascendência do postulante:

“Portanto, as tais causas mais importantes para ser algum recebido, acompanham a quem ao Senhor nosso se acha de boa mente, de condição fácil ou doce, de entendimento claro, de boa fama, de honesta e sã progênie (grifo nosso), de corpo são e de aparência honesta 'e de voz ou loquela clara”,86.

Comparando os dois documentos, Impedimenta Quaedam (1546) e Declarationes in Examen (1548-49), nota-se que aconteceu um recuo relativo do setor intolerante de Companhia em relação aos cristãos novos. Pois enquanto que o

\footnotetext{
${ }^{85}$ Monumenta Ignatiana Ex Autographis Vel Antiquioribus Exemplis Collecta. Series Tertia. Sancti Ignatii de Loyola. Constitutiones Societatis Jesu. Tomus Primus. Monumenta Constitutionum Praevia. Roma, 1934, Impedimenta Quaedam (1546), p.180.

${ }^{86}$ Monumenta Ignatiana Ex Autographis Vel Antiquioribus Exemplis Collecta. Series Tertia. Sancti Ignatii de Loyola. Constitutiones Societatis Jesu. Tomus Primus. Monumenta Constitutionum Praevia. Roma, 1934.
} 
Impedimenta proibiu o "infame" de ser recebido pela Companhia, o Declarationes deu preferência aos candidatos “de boa fama, de honesta e sã progênie”, mas não proibiu os de má fama e sem honesta e sã progênie de ingressar na Ordem.

Nota-se nos documentos regimentais até agora analisados, mesmo no Impedimenta Quaedam, um relativo equilíbrio entre os jesuítas contra e a favor do ingresso dos cristãos novos na Companhia de Jesus.

Uma carta do Provincial da Espanha, Antônio Araoz, escrita em 1549 para o secretário-geral da Ordem, o cristão novo Juan Polanco, comprova a divisão de opiniões a respeito do ingresso de cristãos novos na Companhia de Jesus: "entre nossos devotos há cisma, uns dizendo que deveríamos usar sinal diferente dos outros clérigos, outros dizendo que não e o mesmo receber cristãos novos”87.

Em 1547 a Catedral de Toledo pôs em vigor seu Estatuto de Limpeza de Sangue. A partir daquele ano todos os cristãos novos estavam proibidos de ingressar na Igreja de Toledo ${ }^{88}$.

Que ralação pode ter havido entre o Estatuto de Toledo e as normas da Companhia de Jesus, especialmente as criadas entre 1546-49?

A Companhia de Jesus, ao dificultar o ingresso de cristãos novos, terá sofrido a influência do movimento discriminador de Toledo e elaborado as normas antisemitas.

Aderindo ao movimento político da Catedral de Toledo contra os cristãos novos através do Impedimenta Quaedam, a Companhia de Jesus endossou a discriminação que havia em Toledo e facilitou a aprovação do Estatuto anti-semita da Igreja toledana.

Declarationes in Examen ,1548-49 (?). Declarationes Sobre Algunos Lugares del Examen de los que Desean Entrar en la Compañía de Jesú Nuestro Criador y Señor, p.251.

${ }^{87}$ Monumenta Historica Societatis Jesu. Epistolae Mixtae, Tomo II, Fascículo II. Madrid, 1899, p.314.

88 "ESTATUIMOS Y ORDENAMOS: que de aquí adelante, para siempre jamás., todas las personas que en la dicha iglesia obieren de ser beneficiados y tener entrada en ella, ansí dignidades y canónigos, como racioneros, capellanes y clerizones sean personas ilustres ó nobles, ó hijos dalgo, ó letrados graduados en famosa universidad, con que todos los sobredichos sean christianos viejos, é que ninguno de todos los sobredichos descienda de linaje de judíos, ni de moros, ni de herejes é que sin la dicha qualidad de christianos viejo ninguno de todos los sosodichos sea recibido ni admitido en ella..." In Epistola Mixtae, 
Houve uma polêmica muito intensa entre a Província espanhola da Companhia de Jesus e o Arcebispo da Catedral de Toledo Juan Martínez Silíceo a respeito da presença de cristãos novos no Colégio da Companhia (que analisaremos posteriormente). O Arcebispo Siliceo não queria que a Companhia acolhesse os cristãos novos, uma vez que o Estatuto da Catedral já os havia excluído ${ }^{89}$.

É razoável supor que a Catedral de Toledo foi muito mais anti-judaica do que a Companhia de Jesus, pois a Ordem sofreu pressão política por parte da Igreja de Toledo para discriminar os cristãos novos.

As Declarationes in Examen chamam a atenção pelo vocabulário. As expressões "boa fama" e "honesta e sã progênie" estão juntas, dando a entender que a boa fama dependia da ascendência do candidato. Ter "honesta e sã progênie”, ou seja, não possuir sangue judeu seria uma precondição para possuir "boa fama".

Ao estudar os Estatutos de Limpeza de Sangue espanhóis Albert A. Sicroff encontrou uma íntima correlação entre limpeza de sangue, honra e nobreza na sociedade espanhola e "a opinião segundo a qual nem o sacramento do batismo nem a prática das virtudes cristãs podiam mudar o fato da origem judia de um cristão novo. Ser cristão novo era uma questão de sangue e temos visto que não se podia criticar abertamente esta opinião com impunidade" ${ }^{90}$.

Em 1550 foi composto mais um documento que fez referência aos cristãos novos. Nele encontramos a mesma pergunta feita aos candidatos em 1546: "Se vem de cristãos velhos ou novos e como" ${ }^{91}$. Ambos os textos são muito semelhantes, tendo sido, inclusive, mantido o mesmo nome (Examen Cum Declarationibus).

\footnotetext{
Tomo II, Madrid, 1899, p. 626, Translado del Estatuto que el Ilustrísimo y Reverendísimo Señor Don Juan Martínez Siliceo... promulgó en 23 de Julio de 1547, apud Gamero, Historia de Toledo, p.1092.

89 Juan Martinez Siliceo foi preceptor de Felipe II, Bispo de Cartagena, Arcebispo e Cardeal. In Antônio, Nicolás. Bibliotheca Nova. Tomo I, p. 737. Citado nas Cartas de San Ignacio de Loyola. Fundador de la Compañía de Jesus. Tomo III. Madrid, 1877, p. 13. Para ver mais sobre o Arcebispo Juan Martínez Silíceo e o Estatuto de Limpeza de Sangue do Arcebispado de Toledo consultar Sicroff, Albert A. Los Estatutos de Limpieza de Sangre. Controversias entre los Siglos XV y XVII. Op. cit., pp.125-172.

${ }^{90}$ Sicroff, Albert A. Op. cit. Ver o capítulo VII, item c, especialmente pp. 338-343.

91 Monumenta Ignatiana, Series Tertia, Sancti Inatii de Loyola, Constitutiones Societatis Jesu, Tomus Secundus, Textus Hispanus. Roma, !936, Examen Cum Declarationibus, Textus A, CA, 1550, p.31.
} 
O Examen Cum Declarationibus de 1550 foi menos rigoroso com os cristãos novos do que o Impedimenta Quaedam (1546) e manteve, praticamente, o mesmo conteúdo do Declarationes in Examen (1548-49). Isso significa que o setor da Companhia de Jesus menos intolerante com os cristãos novos ganhou mais espaço na Ordem e, graças a essa preponderância, a Ordem conseguiu adotar uma política relativamente mais flexível com os cristãos novos que nela pretendiam ingressar.

Houve um jesuíta que foi de extrema tolerância para com os cristãos novos, o cristão velho espanhol Alfonso Salmerón ${ }^{92}$. Apesar de não ser totalmente contra a pergunta do Examen Cum Declarationibus, ele questionou a necessidade da sua permanência no Examen: "Veja-se se aquela demanda se vem de cristãos velhos ou novos se há de deixar" ${ }^{\prime 93}$.

É significativo o fato de um jesuíta cristão velho tomar partido dos cristãos novos. Existiam muitos cristãos novos na Companhia de Jesus, e seria de esperar que a reação às normas que os discriminavam partissem deles próprios. Se um cristão velho questionou a política da Companhia que discriminava os cristãos novos, é muito provável que os conversos também tenham reagido à discriminação. E é possível que Alfonso Salmerón não tenha sido o único cristão velho a questionar o anti-semitismo que a Ordem vinha adotando. Seria inseguro fazer essa defesa sozinho, sendo cristão velho. Poderia ter sua ascendência questionada e isso the acarretaria, muito provavelmente, graves problemas. Na metade do século XVI a Companhia ainda era capaz de tolerar posturas humanistas como a de Alfonso Salmerón.

\footnotetext{
${ }^{92}$ Ele fez os Exercícios Espirituais em 1534 junto com Diego Laínez. Conheceu Inácio de Loyola em 1533 e fez parte do grupo dos nove reunidos por Loyola entre 1528 e 1536. Ver O’Malley, John W. Op. cit., pp.27 e 55-56.

93 "Véase si aquella demanda (si v[ie]ne d[e] cristianos viejos o nuevos) se ha de dejar." Monumenta Ignatiana Ex Autographis Vel Antiquioribus Exemplis Collecta. Series Tertia. Sancti Ignatii de Loyola. Constitutiones Societatis Jesu. Tomus Primus. Monumenta Constitutionum Praevia. Roma, 1934, Monum. 46, Observata Patrum, 1551 vel 1552, p.391. Pierre-Antoine Fabre atribuiu esta pergunta a um grupo formado pelos "primeiros padres" reunidos para avaliar a proposta de Constituição escrita em 1550. Entretanto, no documento consultado, o nome citado é o de Alfonso Salmerón. Ver Fabre, Pierre-Antoine. La Conversion Infinie dês Conversos. Des «nouveaux-chrétiens » dans la Compagnie de Jésus. Annales HSS, juillet-août 1999, nº 4, p. 877.
} 
Decididamente Salmerón não estava sozinho entre os cristãos velhos jesuítas tolerantes. Em 1549, na Província espanhola, por exemplo, já havia uma nítida divisão entre os favoráveis e os contrários ao ingresso de cristãos novos na Companhia. O padre ANTÔNIO de Córdoba era favorável aos cristãos novos, afirmando que os mesmos possuíam muita facilidade em assimilar as virtudes cristãs, reconhecendo sua importância para a cristandade ${ }^{94}$.

Entretanto, existe um documento intrigante e surpreendente. Trata-se da Instrução que Francisco Xavier, Provincial da Província de Goa, compôs para o Vice-Provincial e reitor do Colégio de São Paulo (em Goa) Gaspar Barzeu, em Abril de 1552. Nela está escrito que Inácio de Loyola era contrário à admissão de cristãos novos na Companhia: "Guardai-vos de nunca receber pessoas para a Companhia que sejam de pouca idade, nem outros que o Pe. Ignacio defende que se não recebam, como são os que vem da linhagem hebreorum;"95

A Instrução foi redigida antes da viagem que Francisco Xavier fez para a China (1552). Não conhecemos nenhum documento escrito por Inácio de Loyola que confirmasse a proibição da entrada de cristãos novos na Companhia. Entretanto, ocorreu um fato que pode esclarecer a aparente contradição do fundador da Ordem. Francisco Xavier demitiu António Gomes do cargo de reitor do Colégio São Paulo (em Goa). Em seu lugar colocou Gaspar Barzeu. Quem foi António Gomes? Era membro de uma família de posses da Ilha da Madeira, mestre em artes, doutor em teologia e especialista em direito canônico. Foi o "procurador das missões fora de Goa.” Em seu reitorado demitiu os estudantes nativos e foi contra a admissão dos brâmanes ${ }^{96}$. Não era favorável à presença de cristãos novos na Companhia, e menos ainda a que eles assumissem cargos de comando na Ordem, como aconteceu com Henrique Henriques.

\footnotetext{
${ }^{94}$ Ver Fabre, Pierre-Antoine. Op. cit., p. 882.

95 Monumenta Histórica Societatis Iesu. Epistolae S. Francisco Xavierii. Aliaque Eius Scripta. Ediderunt G. Schurhammer S. I. et I. Wicki S. I. Tomus II (1549-52). Roma, Apud “Monumenta histórica Soc. IESU, 1945, Instructio Quarta Pró P. Baraeo de Modo AGendi, pp. 418-19.

${ }^{96}$ Ver O’Neill, Charles E., S. I. e Domínguez, Joaquín Ma', S. I.Op. cit., Vol. II, pp.1770-71.
} 
É provável que a Instrução proibindo Gaspar Barzeu de receber os cristãos novos tenha sido feita para satisfazer uma exigência não do Geral da Companhia, Inácio de Loyola, mas sim para atender aos sentimentos anti-semitas de António Gomes, que além de ter sido reitor do Colégio São Paulo, era o procurador das missões fora de Goa. Apesar de ter perdido a reitoria, António Gomes continuava exercendo cargo de comando na Província (Procurador). Além disso, era talentoso e filho de família abastada da Ilha da Madeira. Portanto, devia ser respeitado. Foi a forma que Francisco Xavier encontrou para respeitá-lo, orientando Gaspar Barzeu para não receber cristãos novos. Havia um agravante. Gaspar Barzeu era holandês e estudou em Lovaina. ${ }^{97}$ Isso quer dizer que até à conclusão dos estudos, não sofreu influência da intolerância ibérica contra os cristãos novos. Portanto, durante o seu reitorado o ingresso dos conversos estaria, a priore, facilitado.

Henriques Henrique foi noviço franciscano, isso o impedia de ser admitido pela Companhia, conforme impedimento $\mathrm{n}^{\circ}$ 6: "se algum houvesse tomado hábito de religião de freis ou clérigos, vivendo algum tempo com eles em obediência, havendo feito profissão ou não a havendo feito" e era cristão novo. Mesmo assim Francisco Xavier, além de tê-lo recebido (Henrique Henriques, como visto anteriormente, foi enviado para Goa por Simão Rodrigues), o confirmou na função de superior regional (Costa da Pescaria) em $1549^{98}$.

Em 1554 o ingresso de Henrique Henriques na Companhia de Jesus voltou a ser considerado em uma carta escrita por Juan Polanco, em nome de Inácio de Loyola. Esta missiva foi enviada para Diogo Mirão, Provincial da Província portuguesa (1552-55). Nela está literalmente escrito que ser cristão novo não era impedimento para ingressar na Companhia: "E advirta que ser de linhagem de

\footnotetext{
${ }^{97}$ Ver O’Neill, Charles E., S. I. e Domínguez, Joaquín Mª, S. I.Idem, Vol. I, p. 427.

${ }^{98}$ Ver O’Neill, Charles E., S. I. e Domínguez, Joaquín Mª S. I. Idem, Vol. I, pp. 177-78. Francisco de Borja Medina, apesar de conhecer a carta de Francisco Xavier, não analisou os prováveis motivos de constar na missiva a vontade de Inácio de Loyola impedir o ingresso dos cristãos novos na Companhia de Jesus. Medina, Francisco de Borja. Op. cit, p. 50.
} 
cristão novo não é impedimento que exclua da Companhia" "99 (grifo nosso). Esta afirmação encerra a questão a respeito da veracidade da Instrução escrita por Francisco Xavier, onde ele afirmou que Inácio de Loyola era contrário ao ingresso de cristãos novos na Ordem. Na mesma correspondência lê-se que os cristãos novos eram homens difíceis, e que por isso devia haver mais rigor na sua seleção: “...embora faça abrir os olhos mais para o receber os tais com provas suficientes, pela fama que muitas vezes acha-se em semelhantes homens, que é ser difíceis.”"100. E apesar disso, dizia a carta, a Companhia não os excluía: “y disto en fuera, (ou seja, fora o fato de serem difíceis) en la Compañía non est distinctio jud[a]ei et gr[a]eci etc ${ }^{101}$, quando são unidos en el mismo spíritu del divino servicio con los otros.”

No mesmo período em que Alfonso Salmerón duvidou da conveniência em manter a pergunta que discriminava os cristãos novos no processo de seleção dos futuros jesuítas (1551-52), Nicolau Bobadilla (um dos fundadores da Companhia) propôs “que se hiziesen Constituciones generales de los colegios, y se leyessen quatro uezes al anno"102.

Que relação pode ter existido entre esta proposta de Nicolau Bobadilha ${ }^{103}$ e a questão regimental da Companhia de Jesus relativa ao ingresso dos cristãos novos? Como já foi visto, os cristãos novos estavam impedidos de frequentar o Colégio de Coimbra (Colégio de Jesus) há cerca de cinco anos. Ao que se sabe, este era o único colégio que, naquela época, excluiu os cristãos novos. Além de ter sido o único, ele

\footnotetext{
${ }^{99} Y$ advierta $V . R$. que el ser de linaje de $x .{ }^{\text {nos }}$ nuevos no es impedimento que excluya de la Compañía. In Monumenta Ignatiana Ex Autographis Vel Ex Antiquiobus Exemplis Colleta - Serie Prima - Sancti Ignatii de Loyola - Societatis Jesu Fundatores - Epistolae et Instructiones, Tomus Sextus. Matriti, 1907, pp. 569-70.

100 "aunque hace abrir los ojos más para el recibir los tales con pruebas suficientes, por loa que suele muchas beses hallarse en semejantes hombres, que es ser difíciles;” In Monumenta Ignatiana. Idem, ibidem.

${ }^{101} \mathrm{Na}$ Companhia não há distinção entre judeu e grego.

${ }^{102}$ Monumenta Ignatiana Ex Autographis Vel Antiquioribus Exemplis Collecta. Series Tertia. Sancti Ignatii de Loyola. Constitutiones Societatis Jesu. Tomus Primus. Monumenta Constitutionum Praevia. Roma, 1934. Idem, p.396. Pierre-Antoine Fabre afirmou que Nicolau Bobadilla era "converso". Fabre, Pierre-Antoine. Op. cit., p.889. Antônio Araoz informou a Inácio de Loyola que alguém havia lhe dito que Nicolau Bobadilla era filho de "tornadiço" (judeu convertido ao catolicismo), portanto, cristão novo. Ver Carta de Antônio Araoz para Inácio de Loyola (14. 01. 1552. In Epistolae Mixtae. Tomo II. Madrid, 1899, p. 656.

${ }^{103}$ Corria o rumor de que Nicolau Bobadilha era cristão novo: "uno me digo que sabía de cierto que Mte. Bobadilha era hijo de un tornadiço.” In Epistolae Mixtae, Tomo II, Madrid, 1899, Extrato da Carta de Antônio Araoz enviada para Juan de Polanco em 14. 01. 1552, p. 656.
} 
estava contrariando um dos princípios mais caros da própria Companhia de Jesus, a obediência. Na “Fórmula” da Ordem, confirmada pelo Papa Júlio III, está escrito:

"Façam também todos voto de obedecer, em todas as coisas que dizem respeito à observância desta nossa Regra, ao Superior da Companhia (para cujo cargo se procurará eleger, por maioria de votos, aquele que for mais idôneo, conforme se há de declarar nas Constituições). O Geral tenha sobre a Companhia, toda a autoridade e poder que for útil para a boa administração, correção e governo da mesma Companhia.”"104.

Sendo assim, se deduz que Nicolau Bobadilha, ao defender a idéia de uniformizar as regras (“Constituições”) dos Colégios, estava sendo coerente com o voto de obediência e, por isso, se pronunciando contra o regimento do Colégio de Coimbra. Além disso, Nicolau Bobadilha deve ter percebido que naquele Colégio os princípios cristãos de benignidade, mansidão e caridade contidos na confirmação da Fórmula da Companhia, estavam longe de serem aplicados.

Portanto, que, no que se refere à questão dos cristãos novos na Companhia, Nicolau Bobadilha pensava de modo muito semelhante ao de Alfonso Salmerón.

Havia uma facção, talvez majoritária, que era favorável à idéia de que os colégios e casas da Companhia de Jesus tivessem regras próprias, específicas, sujeitas a mudanças e, portanto, mais flexíveis, enquanto que as regras a serem incluídas nas Constituições deveriam ser mais universais, imutáveis e aplicadas com maior rigor: “...parece se deban poner de aparte las reglas de casas o collegios que son más particulares y mutables, y cuya obseruatión no es tan importante, y aparte

\footnotetext{
${ }^{104}$ Constituições da Companhia de Jesus e Normas Complementares. Fórmulas do Instituto da Companhia de Jesus Confirmadas pelo Sumo Pontífice Júlio III (Carta Apostólica “Exposcit debitum). Op. cit., p.26. E nas Fórmulas aprovadas em 1540 pelo Papa Paulo III lê-se: "Façam todos voto de que hão de obedecer ao Superior da Companhia em tudo o que diz respeito nossa Regra. E o Geral mande, portanto, aquilo que lhe parecer oportuno para alcançar o fim que lhe foi proposto por Deus e pela Companhia; na sua prelazia,
} 
las Constituciones que son más universales y inmutables y cuya obseruatión más importa»105. Este texto preparatório das Constituições foi composto entre 1547 e 1550, e talvez quisesse dizer que não era da competência do Colégio de Coimbra legislar sobre os cristãos novos, já que esta questão deveria ser incluída nas regras “universais”. Como não se sabe o que aconteceu com o regimento do Colégio de Coimbra, é possível que ele não se enquadrasse, integralmente, até aquele momento, nos parâmetros da maioria dos dirigentes da Companhia.

Em 1552, ano da demissão de Simão Rodrigues do cargo de Provincial, começou a promulgação das Constituições. O jesuíta Antônio Astrain, historiador da Companhia de Jesus, apontou como uma das funções das Constituições “dar uniformidade à vida dos colégios” ${ }^{106}$. Portanto, é muito provável que a promulgação das Constituições tenha sido um dos fatores que causou o afastamento de Simão Rodrigues da função de provincial de Portugal, devido à incompatibilidade existente entre o regimento do Colégio de Jesus e as Constituições.

\section{JOÃO III DECIDE}

Em Fevereiro de 1555 Inácio de Loyola escreveu uma carta para Diego Mirão, Provincial em Portugal (1552-55). Nela encontra-se, em linhas gerais, a política adotada pela Companhia de Jesus na admissão dos cristãos novos portugueses. Cabia ao rei de Portugal (escreveu Inácio de Loyola), e não à Companhia, decidir sobre o ingresso de cristãos novos nos Colégios da Ordem existentes no reino (Lisboa, Évora e Coimbra). Portanto, caso o rei resolvesse que a Companhia não devia recebê-los, poderiam ser enviados para onde fossem menos conhecidos, e caso alguém importante se incomodasse de vê-los na Ordem, o

porém, lembre-se sempre da benignidade, mansidão e caridade de Cristo e das normas de Pedro e Paulo, e tanto ele como a Congregação tanham sempre diante dos olhos este modelo.” Idem, ibidem.

105 Monumenta Ignatiana, Series Tertia, Sancti Inatii de Loyola, Constitutiones Societatis Jesu, Tomus Secundus, Textus Hispanus. Roma, 1936. Constitutionum Textus a (1547-1550), Fin y Propriedades de las Constitutiones, p.129.

${ }^{106}$ Astrain, P. Antônio S. J. Op. cit., p. 78. 
Provincial tomaria as medidas que considerasse mais acertadas. Enfim, o ideal seria, segundo Inácio de Loyola, não mantê-los em Portugal quando fossem muito conhecidos. Ou seja, os cristãos novos portugueses que desejassem ingressar na Companhia de Jesus ficavam totalmente dependentes do monarca português e sujeitos ao "humor" da nobreza e podendo ser transferidos de Portugal a qualquer momento.

A Companhia de Jesus poderia receber sim os cristãos novos de Portugal, se essa fosse a decisão do monarca. Entretanto, Inácio de Loyola não sujeitou completamente os cristãos novos portugueses à intolerância das pessoas de "respeito":

“Acerca dos escolares que insistem em ser recebidos, guardadas as circunstâncias, será bom alargar a mão em admiti-los, sendo bons sujeitos. Dos que descendem de cristãos novos, se o rei não quer que sejam admitidos, ou não para seu reino determinadamente, faça-se o que à $\mathrm{S}$. A. achar melhor; e eles, sendo bons sujeitos se podem enviar para outras províncias da Espanha, ou para estas partes da Itália, onde não existe esses inconvenientes. Se o rei não se determina ao contrário, poderíamos admitir também para esse reino, embora poderiam enviar-se para onde não fossem tão conhecidos, mudando-lhes o nome ou sobrenome. Finalmente, os bons por isto não devem excluir-se; e para secundar em alguma maneira o humor das gentes a quem se deve ter respeito, toma-se algum meio, que pareça mais adequado" ${ }^{107}$.

\footnotetext{
107 "Acerca de los scholares que hazen instancia por ser recibidos, guardadas las circunstancias, será bueno alargar la mano en admitirlos, siendo buenos sujetos. De los que dependen (descendem) de xpianos. (cristãos) nuevos, si el rey no quiere se admitan, ó no para su reino determinadamente, hágase lo que á S. A. parecerá; y ellos, siendo buenos sujetos, se pueden enviar á las otras provincias d'España, ó para estas partes de Italia, donde no ay esos respetos. Si el rey no se determina á lo contrario, podríamos admitir también para ese reino, aunque podrían enviarse á donde no fuesen tan conocidos, mudándoles el nombre ó sobrenombre. Finalmente, los buenos por esto no deben excluirse; y para secundar en alguna manera al
} 
A partir da carta escrita por Inácio de Loyola em Fevereiro de 1555 para Diego Mirão, a política adotada pela Companhia em relação ao ingresso de cristãos novos pode ser assim resumida: a Companhia de Jesus tomava suas decisões em relação aos cristãos novos em função do que lhe fosse mais útil e conveniente. Em outras palavras, a Companhia os recebia quando isso não causasse problemas para ela, como por exemplo, indisposição com os monarcas, a nobreza, as cortes, o clero, enfim, com quem fosse mais importante - segundo os cálculos da Ordem - do que com os cristãos novos.

\section{O CASO DO ARCEBISPO DE TOLEDO}

Entre Outubro de 1551 e Junho de 1552 aconteceu uma dificílima disputa entre o Arcebispo de Toledo, Juan Martinez Siliceo, e a Companhia de Jesus. O desfecho desta contenda evidencia a forma pela qual a Companhia solucionava as questões relativas aos cristãos novos e confirma a mesma lógica presente na carta escrita pelo Geral (Inácio de Loyola) para o Provincial português (Diego Mirão) em Fevereiro de 1555, analisada anteriormente. Apenas modificaram-se os agentes dos fatos.

O primeiro documento que tratou desta problemática foi uma carta enviada para Inácio de Loyola escrita por Francisco Villanueva (reitor do colégio da Companhia em Alcalá de Henares) em 30 de Outubro de $1551^{108}$.

A Arcebispo Juan Martinez Siliceo ordenou que o Colégio da Companhia de Jesus fosse fechado. E mesmo após o fechamento do mesmo, proibiu (através de um mandamento dirigido aos padres a ao Cabido de Alcalá de Henares) os jesuítas de confessar, predicar e administrar os sacramentos sem que antes os padres fossem por

humor de las gentes á quienes se debe tener respecto, tomase algún medio, que parezca más acertado.” In Monumenta Ignatiana, Séries Prima, Epistolae et Instructiones, Tomus Octavus. Matrit, 1909, p. 446.

108 Epistolae Mixtae, Tomo II, Fascículo II. Madrid, 1899. Carta de Francisco Villanueva para Inácio de Loyola, pp. 607-610. 
ele examinados. Além disso, ordenou ao vigário intimar e ler publicamente o mandado.

Francisco Villanueva, aconselhado por um certo doutor Vergara e pelos irmãos, apresentou as bulas ${ }^{109}$ ao vigário e ao Cabido ${ }^{110}$. O resultado foi a suspensão da leitura pública do mandado. Francisco Villanueva foi aconselhado pelo vigário e cabido a apresentar as Bulas ao Arcebispo para que ele as conhecesse. Antes de se encontrar com o Arcebispo em Toledo, Francisco Villanueva foi à Corte, onde esteve com o núncio (cardeal João Poggio). Este o recebeu muito bem, assumindo o caso com todo interesse em solucioná-lo. Até mesmo escreveu para o Arcebispo tentando convencê-lo de que a Companhia possuía as Graças concedidas pela Sé Apostólica. Francisco Villanueva, finalmente, foi para Toledo com a carta do núncio para encontrar-se com o Arcebispo ${ }^{111}$.

Foi feita uma série de questionamentos ao jesuíta. O Arcebispo queria saber, por exemplo, por que a Ordem se chamava Companhia de Jesus, pois para Juan Martinez Siliceo esta denominação dava a entender que os demais católicos não eram de Jesus. O Arcebispo perguntou ainda por que os jesuítas pregavam e confessavam sem sua autorização e por que fundaram a casa de Alcalá sem sua licença. Após estas indagações Juan Martinez Siliceo teceu duras críticas à Companhia. Por exemplo, não via nos "Exercícios Espirituais” a presença do Evangelho e considerou que a nova Ordem era motivo de escândalo para o povo, além de desonrar o cavaleiro.

Após ouvir as respostas de Francisco de Villanueva, o Arcebispo afirmou que não existia autoridade superior a ele, e que no seu Arcebispado o papa não era necessário. Inclusive não respondeu a carta do núncio e, após a reunião, mandou

\footnotetext{
${ }^{109}$ As bulas apresentadas eram a uma espécie de autorização concedida pelo papa e pela Sé Apostólica aos dez primeiros membros da Companhia de Jesus e depois estendida aos jesuítas que fossem licenciados em Teologia. Com ela se poderia pregar, confessar, absolver, ministrar sacramentos, realizar missa e possuir e ler livros heréticos. Ver Monumenta Ignatiana. Séries Prima. Epistolae et Instructiones. Tomus Primus. Matrit, 1903. Carta de Inácio de Loyola para Simão Rodrigues, (Roma, $1^{\circ}$ de Novembro de 1542), p.232.

${ }^{110}$ Em espanho se escreve cabildo (organismo eclesiástico diocesano de apoio ao bispo).

111 Além da carta do núncio, Francisco Villanueva apresentou mais uma, de D. Leonor Mascarenhas (portuguesa, preceptora de Felipe II e devota do Arcebispo Juan Martinez Siliceo).
} 
publicar o mandamento que proibia a Companhia de Jesus confessar, pregar e administrar os sacramentos sem que antes os jesuítas fossem por ele examinados, o que segundo Francisco de Villanueva, causou grande escândalo ${ }^{112}$.

Em Toledo a Companhia recebeu grande apoio até mesmo dos amigos de Juan Martinez Siliceo. É o que afirmou Francisco Villanueva que, entretanto, não apresentou as Bulas ao Arcebispo porque, segundo ele, o Provincial (Antônio Araoz) deveria estar ciente do que estava acontecendo.

Dentre os devotos da Ordem houve até quem sugerisse que a Companhia de Jesus, através do papa, comunicasse ao Inquisidor Geral o que estava acontecendo no Arcebispado de Toledo. Mas esta proposta não foi colocada em prática pelos jesuítas.

Algumas questões não estão claras no documento. Por que o Arcebispo Juan Martinez Siliceo fez questão de examinar os jesuítas? E por que a Companhia de Jesus era, na opinião dele, motivo de escândalo para o povo e causa de desonra para o cavaleiro? O motivo alegado por Francisco Villanueva para não apresentar as Bulas ao Arcebispo pode ser considerado satisfatório ou suficiente, já que ele partiu de Alcalá de Henares com esse objetivo?

Quinze dias depois de escrita a primeira carta, foram enviadas mais três (15. 11. 1551), todas para Inácio de Loyola, sendo uma de Francisco Villanueva e duas de Miguel de Torres. Nelas encontram-se, dentre outras informações, o relato do segundo encontro de Francisco Villanueva (agora acompanhado por Miguel de Torres, o qual foi indicado por Antônio Araoz) com o Arcebispo ${ }^{113}$.

Em uma das cartas de Miguel de Torres consta a informação de que as Bulas foram apresentadas ao Conselho Real, o qual teria dado provisão para intimá-las a quem fosse necessário ${ }^{114}$. Ocorre que Francisco Villanueva escreveu exatamente o contrário, ou seja, que as Bulas não foram apresentadas ao Conselho Real, porque o

\footnotetext{
112 Ver Epistolae Mixtae. Tomo II. Op. cit., p. 632.

113 Epistolae Mixtae. Tomo II. Op. cit., pp. 621-626.

${ }^{114}$ Idem, p. 622.
} 
núncio desistiu de apresentá-las, achando melhor enviar carta para o Arcebispo ${ }^{115}$. E além disso, elas não teriam sido apresentadas porque, argumentou o próprio Francisco Villanueva, antes seria necessário comunicar ao Provincial (Antônio Araoz) o que estava ocorrendo ${ }^{116}$. É difícil supor o motivo desse desencontro de informações.

Para esta reunião os jesuítas receberam o apoio direto de um abade e de um cardeal e outra carta foi escrita pelo núncio (Poggio) destinada ao Arcebispo. O cardeal de Santiago, Fr. João Alvarez de Toledo, também escreveu para ele apoiando a Companhia, e o abade de Valladolid, Alonso Enriques, amigo do Arcebispo, serviu de intermediário, além de ter utilizado todos os meios disponíveis para mudar os propósitos do Arcebispo, porém sem obter êxito, já que todo esse esforço não impediu que o Arcebispo ordenasse que "se lessem os éditos publicamente em Alcalá e aqui em Toledo"117.

Inicialmente Juan Martinez Siliceo suspeitou que Francisco Villanueva fosse cristão novo: "Por ventura pensou que eu tinha raça de confesso, que assim os chama ele, e a mim não se declarou, embora bem via eu, que, pois ele não se satisfazia com as razões que eu dava às suas dúvidas, que inclinava de outra

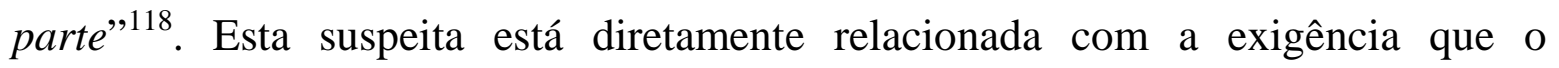
Arcebispo fez de examinar todos os jesuítas. Portanto, a questão dos cristãos novos começou a se manifestar e a verdadeira causa do problema do Arcebispo com a Companhia começava a ficar clara.

Quando Miguel de Torres e Francisco Villanueva tentaram apresentar as Bulas o Arcebispo reagiu dizendo que “queimaria a todos, etc.” E quando Miguel de Torres enfatizou a aprovação da Sé Apostólica (no caso, trata-se das próprias Bulas), o Arcebispo respondeu que isso não era motivo suficiente para que ele não

\footnotetext{
115 Idem, p. 608.

${ }^{116}$ Idem, p. 609.

117 Epistolae Mixtae. Tomo II. Op. cit., p. 623.

${ }^{118}$ Idem, p. 625.
} 
suspeitasse da Companhia, já que esta cometia, em suas palavras, outras maldades como abrigar pessoas, etc ${ }^{119}$.

Finalmente, o Arcebispo da Arquidiocese de Toledo, Juan Martinez Siliceo, resolveu esclarecer a verdadeira razão de sua contenda com a Companhia de Jesus e falou francamente com o Padre Miguel de Torres:

"Depois lhe chamou à parte [ao $\mathrm{P}$. Torres] e lhe disse, que ele não tinha inimizade com a Companhia, nem a queria mal; porém que ele fazia isto porque na Companhia se fizesse o estatuto que ele fez na igreja de Toledo, e que ele pretendia que não houvesse cura nem beneficiado que fosse desta casta, nem pudesse confessar nem predicar, etc" ${ }^{\text {"20 }}$.

É oportuno observar que já transcorriam mais de quatro anos que o Arcebispo havia promulgado o Estatuto de Limpeza de Sangue em sua Arquidiocese (23 de Julho de 1547).

Logo após ter apresentado o motivo pelo qual perseguia a Companhia, o Arcebispo prometeu que seria o maior amigo da Ordem e quem mais a favoreceria caso ela adotasse o Estatuto: "e que porque venha a Companhia a fazer o mesmo, entrava por aqui, e que se isto se faz na Companhia, que fará, e que não haverá maior amigo que ele, e que mais a favoreça." ${ }^{\text {"121. }}$

Apesar dos dois representantes da Companhia diante do Arcebispo não possuírem poderes para tomar qualquer decisão relativa ao assunto em pauta, ambos rejeitaram a proposta de Juan Martinez Siliceo. Francisco Villanueva escreveu para Inácio de Loyola argumentando que, caso a Ordem fizesse o que o Arcebispo pretendia (adotar o Estatuto), ela teria mais perdas do que ganhos. A Companhia, continuou Francisco Villanueva, perderia muitos que tivessem interessados em fazer os Exercícios e que quisessem se confessar. Deu a entender que não seria possível

\footnotetext{
${ }^{119}$ Idem, ibidem.

${ }^{120}$ Idem, p. 626.
} 
aplicar o Estatuto porque “... atualmente há poucos grandes em Castela que não estejam mesclados”122. Lamentou a discriminação generalizada sofrida pelos cristãos novos: "Es muy gran lástima que á estos probrezitos no parece que les querían dar lugar en la tierra"123. Reconheceu, corajosamente, que havia mais cristãos novos virtuosos do que cristãos-velhos e fidalgos. E disse que, caso tivesse forças suficientes, seria o procurador dos conversos: "eu queria ter forças para me fazer procurador deles, principalmente que vemos no dia de hoje neles mais virtuosos que nos velhos e fidalgos." ${ }^{24}$.

A reação de Miguel de Torres foi mais enfática. Sugeriu que Inácio de Loyola sugerisse que o Papa escrevesse uma carta para o Arcebispo tratando da questão relativa à questão Companhia e dos cristãos novos. Propôs ainda outra medida que, segundo ele, seria ainda mais eficaz: encaminhar o problema para o Inquisidor Geral. Porque, dizia Miguel de Torres, a Inquisição em Toledo era mais temida do que o próprio papa: "especialmente encarregasse este negócio ao inquisidor maior, porque aqui mais temor têm à Inquisição que ao Papa."

Com estas propostas Miguel de Torres estava tentando acelerar a solução do impasse com o Arcebispo. O que, aliás, era o desejo de devotos influentes da Companhia em Castela. A demora estava provocando efeitos negativos entre eles: "Todos os devotos daqui dizem que importa muito solucionar este negócio, porque muitos estão desanimados, e outros escandalizados em ver nossa paciência."126. Caso a Ordem não reagisse com mais determinação, dizia Miguel de Torres, ela sofreria profundo desgaste entre seus devotos, e que calar-se diante das atitudes do Arcebispo seria uma ofensa a Deus. Era necessário reagir, argumentava Miguel de Torres, para que todos se convencessem de que a Companhia era uma Ordem de

\footnotetext{
${ }^{121}$ Epistolae Mixtae. Tomo II. Op. cit., p. 626.

122 "el dia de hoy ay pocos grandes en Castilla que no estén mezclados". In Idem, ibedem.

123 Idem, ibedem.

124 “yo querría tener fuerzas para me hacer procurador de ellos, mayormente que vemos el día de hoy en ellos más virtuosos que en los viejos e hidalgos.” Idem, ibedem.

${ }^{125}$ Epistolae Mixtae. Tomo II. Op. cit., pp. 624-25.

126 “Todos los devotos de acá dicen que importa mucho sacar este negocio á claridad, porque muchos están acobardados (desanimados), y otros escandalizados en ver nuestra paciencia.” Idem, p. 625.
} 
inspiração divina e não uma invenção humana: “muitas pessoas graves nos tem dito que lhes parece que se ofende a Deus em tanto calar, e que damos ocasião para que pensem muitos que esta Companhia não está tão corroborada como convinha, e que deve ser invenções de homens e novidades, como os êmulos dela com tanto ânimo predicam." 127.

Após constatar que os devotos da Companhia de Jesus estavam sendo perseguidos e suspeitar que ocorria a mesma coisa com os seus simpatizantes, Francisco de Villanueva apoiou a proposta elaborada por Miguel de Torres de denunciar o Arcebispo ao Tribunal do Santo Ofício: "Há tanta perseguição em Toledo contra os devotos nossos...Seria grande coisa se se pudesse pôr algum freio a estes, que parece professam perseguir aos que se querem chegar a nosso Senhor, principalmente se fosse algum mandado de inquisição." ${ }^{28}$.

Com o agravamento da situação devido ao prolongamento do impasse com o Arcebispo, Francisco de Villanueva concluiu que as Bulas deviam ter sido apresentadas a Juan Martinez Siliceo, com requerimento judicial, logo no primeiro encontro ocorrido entre eles. As perspectivas do padre para solucionar o impasse não eram muito otimistas, já que cada uma das partes tinha o seu "juiz”; ${ }^{129}$ apesar do apoio que a Companhia recebeu do Conselho ${ }^{130}$ e do compromisso que o núncio fez com a Ordem de encontrar-se pessoalmente com o Arcebispo para lhe dizer que devia proceder segundo as normas estabelecidas ${ }^{131}$.

\footnotetext{
127 "muchas personas graves nos ha dicho que les parece que se ofende Dios en tanto callar, y que damos ocasión á que piensen muchos que esta Compañía no está tan corroborada como convenía, y que debe ser invenciones de hombres y novedades, como los émulos Della con tanto ánimo predican.” Idem. P. 633.

128 "Ay tanta persecución en Toledo contra los devotos nuestros...Seria gran cosa si se pudiese poner algún freno á estos, que parece profesan perseguir á los que se quieren llegar á nuestro Señor, máxime si fuese algún mandado de inquisición.” Excerto da carta do padre Francisco de Villanueva para o Geral Inácio de Loyola datada em 20 de Novembro de 1551. In Epistolae Mixtae. Idem, p. 634.

${ }_{129}$ Pode se dizer advogado.

${ }^{130}$ O Conselho autorizou a Companhia a notificar as Bulas ao Arcebispo a aos corregedores de as intimar, e amparar e favorecer a Ordem (Os Conselhos eram organismos colegiados, de caráter consultivo que, durante a Idade Moderna, assessoravam os reis da Espanha. Em geral tinham atribuições de justiça e de governo). Ver carta do padre Francisco de Villanueva para o Geral Inácio de Loyola de 20 de Novembro de 1551. In Epistolae Mixtae. Tomo II. Op. cit., p. 633.

${ }^{131}$ Ver Idem, ibidem.
} 
Devido às consequências das desavenças entre a Companhia e o Arcebispo de Toledo, Francisco de Villanueva solicitou ajuda financeira a Inácio de Loyola. Sem este auxílio, dizia ele, não seria possível que a Ordem continuasse a "auxiliar as almas a produzirem seus frutos" 132 .

Em 12 de Dezembro de 1551 as Bulas foram intimadas por Francisco de Villanueva. Ele foi acompanhado por um notário apostólico (Francisco Martínez), o qual trazia consigo uma provisão do Conselho Real. Porém, caberia a um notário intimá-las para se tornar oficial. Talvez por ter sido uma intimação extra-oficial, esta não teve nenhum efeito prático. Pois nenhuma das cartas escritas após a data desta intimação se referiu a este fato.

A reação de Inácio de Loyola ao que estava acontecendo na Arquidiocese de Toledo foi implacável. O Geral da Companhia de Jesus encarregou o seu secretário particular, Juan de Polanco, para escrever ao padre Francisco de Villanueva (02. 01. 1552). Nesta missiva, além da indignação de Inácio de Loyola, existem dados que poderiam fortalecer a Ordem e deslegitimar o Arcebispo.

O início da correspondência aponta para a inversão realizada pelo Arcebispo, que, ao invés de agradecer à Companhia pelo auxílio que vinha dando ao carregar parte do peso da Arquidiocese, resolveu persegui-la ${ }^{133}$.

Entretanto, a Ordem não estava sozinha, dizia Juan de Polanco. O Arcebispo devia estar consciente de que havia autoridades superiores a ele, inclusive, com poderes para excomungá-lo. Portanto, ele não seria capaz de prejudicar a Companhia ${ }^{134}$. Conforme havia constatado Inácio de Loyola, toda a Sé Apostólica estava favorável à Ordem. A Sé considerou um exagero e motivo de transtorno a

\footnotetext{
132 "parece será menester que la mantenencia se aya, ínterin que la cosa va adelante, para que el fruto no cese en las ánimas.” Epistolae Mixtae. Tomo II. Idem, pp. 634-35.

133 “... hemos entendido lo que allá ha intentado el Arzobispo contra la Compañía, en lugar de agradecer lo que le ayuda á llevar parte de su peso. In Cartas de San Ignacio de Loyola. Fundador de la Compañía de Jesus. Tomo III. Madrid, 1887, p. 13.

${ }^{134}$ Ver Cartas de San Ignacio de Loyola. Idem, pp. 14-15.
} 
postura do Arcebispo de Toledo ${ }^{135}$. Além disso, a reputação do Arcebispo na própria Sé Apostólica não era boa, assegurava Juan de Polanco ${ }^{136}$.

Até mesmo o papa (Júlio III) apoiou a Companhia. Ele escreveu para o Arcebispo dizendo-se admirado com o seu procedimento em relação à Ordem. Mandou que fossem suspensos os impedimentos e que nada fosse feito a respeito da Companhia sem sua autorização. Redigiu mais uma correspondência. Agora para o núncio, com o conteúdo semelhante ao da carta enviada para Juan Martinez Siliceo $^{137}$.

Diante desse quadro desfavorável para Juan Martinez Siliceo, restava a ele, em primeiro lugar, corrigir seus erros, para somente depois reformar a Igreja ou ajudar a reformá-la, aconselhou Juan Polanco em nome de Inácio de Loyola ${ }^{138}$.

Na missiva encontra-se uma notícia cujo objetivo não era somente encorajar os jesuítas envolvidos diretamente na controvérsia com o Arcebispo, mas também a Companhia como um todo. Havia um antecedente desfavorável a Juan Martinez Siliceo. Ocorreu em Tíbule (cidade próxima a Roma). O bispo proibiu a Ordem de pregar o Evangelho e administrar os sacramentos. O caso foi levado para o Auditor da Câmara, que deu ganho de causa para a Companhia ${ }^{139}$.

O momento determinante da carta foi quando Inácio de Loyola deixou suficientemente claro que não era da competência do Arcebispo de Toledo, Juan Martinez Siliceo, interferir nas Constituições da Companhia de Jesus, exigindo que nelas fossem incluídos os Estatutos da Arquidiocese: “De vir a concordar com o Arcebispo, aceitando seus desígnios, e aplicando nossas constituições às suas, não é necessário pensar; basta a ele entender o que está a seu cargo.” ${ }^{„ 40}$ Isso significava que o Geral da Companhia, e consequentemente a Ordem, não acatou, naquele

\footnotetext{
135 “Ha parecido acá gran exorbitantia y desconcierto.” Idem, pp. 13-14.

${ }^{136}$ Ver Cartas de San Ignacio de Loyola. Idem, pp. 17-18.

${ }^{137}$ Ver Cartas de San Ignacio de Loyola. Idem, p. 20.

${ }^{138}$ Ver Cartas de San Ignacio de Loyola.Idem. P. 18.

${ }^{139}$ Ver Cartas de San Ignacio de Loyola. Op. cit., pp. 18-19.

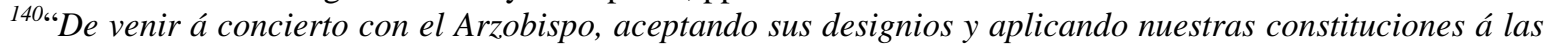
suyas, no es menester pensar; bástale á él entender en lo que está á su cargo. ”Cartas de San Ignacio de Loyola. Idem, p. 19.
} 
momento, a exigência de adotar um Estatuto de Limpeza de Sangue feita pelo Arcebispo.

Em 14 de Janeiro de 1552 o Provincial da Espanha, Antônio Araoz, escreveu para o secretário de Inácio de Loyola, Juan Polanco. Ele demonstrou que não queria aceitar o mandamento do Arcebispo. E somente o aceitou porque o núncio (Poggio), em quem confiava, o convenceu a aceitá-lo. Apesar disso Antônio Araoz procurou a orientação de especialistas em questões jurídicas, e todos lhe asseguraram de que o Arcebispo não podia prejudicar a Companhia. E, ao mesmo tempo, o aconselharam a continuar trabalhando ao lado de Poggio no caso, que graças às Bulas, seria o advogado da Companhia ${ }^{141}$.

Ao saber que a Ordem iria colocar a questão na justiça, o Arcebispo, em represália, comprou as casas vizinhas ao Colégio dos jesuítas ${ }^{142}$. Entretanto, caso a Companhia entrasse em acordo com Juan Martinez Siliceo, diziam muitos, ele doaria as casas aos inacianos ${ }^{143}$. Aliás, conforme comentavam, caso a Companhia de Jesus não recebesse mais cristãos novos em suas casas e colégios localizados na Arquidiocese e transferisse desta os que já haviam sido recebidos (como tanto insistia Juan Martinez Siliceo), a Companhia seria generosamente recompensada pelo Arcebispo $^{144}$. Ou seja, o Juan Martinez Siliceo insistia na adoção, por parte da Companhia, do Estatuto vigente na Arquidiocese. Na essência, era isso o que Antônio Araoz estava dizendo para Inácio de Loyola.

Antônio Araoz, em sua carta, afirmava que foi aconselhado para considerar, com muito cuidado, a idéia da Companhia não receber mais os cristãos novos nas suas casas e colégios. Isso porque, dizia o jesuíta, chegou a notícia de que na Inglaterra havia muitos judaizantes. Todos eles tinham sido “enganados” por um

\footnotetext{
${ }^{141}$ Ver carta de Antônio Araoz para Juan de Polanco (14.01.1552). In Epistolae Mixtae. Tomo II. Op. cit., p. 655.

${ }^{142}$ Estas casas estavam sendo negociadas pela Companhia, como será visto adiante.

${ }^{143}$ Epistolae Mixtae. Tomo II. Idem, ibidem.

144 "El arzobispo de Toledo a echo grande instancia para que, á lo menos en las casas y colegios de su diócesis, no recibamos cristianos. nuevos, y que si alguno ay, le pasemos á otra parte, y dicen que, haciendo esto, hará grandes cosas por la Compañía." Carta de Antônio Araoz para Juan de Polanco (14.01.1552). Epistolae Mixtae. Tomo II. Op. cit., p. 656.
} 
cristão novo ${ }^{145}$. Inclusive, lhe afirmaram que o padre Nicolau Bobadilha era filho de um "tornadiço” (converso). Portanto, poderia acontecer na Espanha, ou em qualquer outro lugar onde houvesse cristão novo, o que ocorreu na Inglaterra.

Se deduz que, em decorrência do precedente inglês, o Provincial da Espanha chegou até mesmo a cogitar a possibilidade da Companhia de Jesus adotar um Estatuto de Limpeza de Sangue (função que, segundo Antônio Araoz, caberia ao Geral da Ordem, Inácio de Loyola) ${ }^{146}$, apesar de haver aqueles que consideravam um escândalo o fato de se pensar em algo do género ${ }^{147}$, e outros que também se escandalizavam com o Estatuto da Arquidiocese $^{148}$. Não está claro quem se escandalizou com a idéia da Companhia ter um Estatuto de Limpeza de Sangue. Mas é possível que os indignados fossem jesuítas ou devotos da Ordem. Seja como for, Antônio Araoz queria que o Geral da Companhia tomasse uma decisão a respeito do Estatuto $^{149}$. Quer dizer, o Provincial espanhol inseriu este tema na pauta da Companhia; era exatamente isso o que queria o Arcebispo. Ocorre que, como já foi visto na correspondência escrita por Juan Polanco - a pedido de Inácio de Loyola para Francisco de Villanueva (02.01.1552), esta possibilidade foi claramente desconsiderada.

A partir do momento em que Antônio Araoz levou em conta a possibilidade da Companhia ter o seu próprio Estatuto de Limpeza de Sangue, estava dado o sinal de que não havia nele a disposição de resistir às exigências do Arcebispo até às últimas consequências. No final da sua carta isto está indubitavelmente demonstrado. Se dependesse dele a pendência com o Arcebispo não seria levada à

\footnotetext{
${ }^{145}$ Idem, ibidem.

${ }^{146}$ Nota-se aqui a postura disciplinada e relativamente tolerante com os cristãos novos de Antônio Araoz. Comportamento distinto do Provincial de Portugal, Simão Rodrigues que, como já foi visto, redigiu e aplicou o regimento do Colégio de Coimbra, o qual excluía os cristãos novos.

147 "En esto no ponemos regla, como no es razón, asta tenerla de V. P., mas de que se mira en ello (grifo meu), aunque por otra ay otros, que, en pensar que se mira en ello, se escandalizan.”. Carta de Antônio Araoz para Juan de Polanco (14.01.1552). In Epistolae Mixtae. Tomo II. Idem, p. 656,

148 "El arzobispo a puesto estatuto en su iglesia que ningún cristianos. nuevo pueda ser canónigo, etc., y á muchos a escandalizado. Carta de Antônio Araoz para Juan de Polanco (14.01.1552). Idem. Pp. 656-57.

149 "Deseamos saber como nos habremos en esto. Carta de Antônio Araoz para Juan de Polanco (14.01.1552). Epistolae Mixtae. Tomo II. Op. cit., P. 656.
} 
justiça. Caso Inácio de Loyola achasse isso conveniente, contactasse com o núncio (Poggio) $^{150}$.

Uma semana após a carta de Antônio Araoz, Francisco de Villanueva tornou a escrever para Inácio de Loyola (20.01.1552). O conteúdo é basicamente informativo. E entre os informes, um é de essencial importância. O padre Miguel de Torres havia se afastado do caso e deixado Francisco de Villanueva sozinho; ele parecia estar mais determinado a lutar contra a discriminação aos cristãos novos. O que é um indício de descaso da Companhia, ou melhor, do provincial espanhol, com o problema. As casas vizinhas ao Colégio da Companhia foram compradas pelo Arcebispo porque a Ordem estava interessada em adquiri-las. Este foi o motivo que esclarece a represália de Juan Martinez Siliceo. E comprou, praticamente, pelo dobro do preço ofertado.

O cardeal Poggio, cumprindo o que havia prometido à Companhia, resolveu ir para Toledo a fim de falar pessoalmente com o Arcebispo a respeito do conflito com a Ordem. Francisco de Villanueva não falou absolutamente nada a respeito desse encontro nesta correspondência (20.01.1552).

$\mathrm{Ou}$ apesar ou graças à perseguição realizada pelo Arcebispo contra a Companhia, havia crescido o número dos seus devotos, amigos e de pessoas fazendo os Exercícios Espirituais, além de ter aumentado o número dos que ingressaram na Ordem.

A informação essencial contida na carta é a seguinte: o Arcebispo havia revogado o mandamento que proibiu a Companhia de pregar, confessar e "dizer" missa sem que ele antes examinasse cada jesuíta. O motivo? As orações, os sacrifícios e os rogos feitos a Deus, incessantemente, pelos irmãos da Companhia ${ }^{151}$.

\footnotetext{
150 “Si por ventura á V. P. no parecieren bien las diligencias que están echas con el Rmo. Poggio acerca de lo del arzobispo de Toledo, y le pareciere que se deba seguir jurídicamente, sería menester, si á V. P. pareciese, que su santidad le cometiese esto al cardenal Poggio por breve particular.” Carta de Antônio Araoz para Juan de Polanco (14.01.1552). Idem. Pp. 659-660.

151 "En este tiempo, no han cesado los hermanos en oraciones y sacrificios, ni cesan de rogar á nuestro Señor por el señor arzobispo: y a [un] se habrá hecho allá. Parece nuestro Señor le va ablandando, y así a ya dado mandamiento, en contrario del que había dado, en favor de la Compañía.”. Carta de Francisco de Villanueva para Inácio de Loyola (20.01.1552). In Epistolae Mixtae. Tomo II. Op. cit., p. 661.
} 
Apesar da intercessão divina, o Provincial Antônio Araoz, juntamente como o padre Tablares, foi a Toledo beijar as mãos e agradecer o favor (grifo nosso) feito pelo Arcebispo $^{152}$.

É evidente que o motivo alegado por Francisco de Villanueva para o Arcebispo suspender as restrições impostas à Companhia de Jesus não são suficientes. Aliás, ele foi "ingênuo" 153 , se considerarmos o que estava acontecendo, como por exemplo, a determinação do Arcebispo e as posturas hesitantes do núncio e do Conselho Real.

Cerca de dois meses depois (16. 03. 1552), Francisco de Villanueva voltou a escrever para Inácio de Loyola. Ele afirmou que não estava satisfeito com a forma pela qual o cardeal (e núncio) Poggio estava conduzindo as negociações com o Arcebispo de Toledo, Juan Martinez Siliceo.

Retomou a questão da intimação das Bulas (a via judicial), as quais não foram intimadas para não contrariar Poggio. Francisco de Villanueva não esclareceu os motivos pelos quais ele considerava tanto o Cardeal. Afinal, a Companhia possuía as Bulas. Entretanto, ele se referiu, de modo indireto e impreciso, aos motivos para respeitar a vontade do Cardeal. Ele era "o refúgio e amparo" da Companhia ${ }^{154}$. É provável que em função do cardeal ter sido considerado o "refúgio e amparo" da Ordem, ele não tenha sido afastado do cargo de "juiz” da Companhia. Francisco de Villanueva chegou a propor a troca de Poggio por outro "juiz", mas chegaram à conclusão (ele e o padre Miguel de Torres) que seria mais conveniente mantê-lo, pois o seu afastamento causaria “inconvenientes”. Quais? Não se sabe. Mas Poggio era o núncio, representante oficial do Papa na Espanha. Com este cargo tanto podia ser um grande apoio para a Companhia em todos os sentidos, quanto poderia dificultar a vida da Ordem.

\footnotetext{
${ }^{152}$ Idem, ibidem.

153 É possível sim que Francisco de Villanueva tenha sido ingênuo. Pois em 1546 ele ainda era estudante. Veja Cartas de San Ignacio de Loyola. Fundador de la Compañía de Jesus. Tomo III. Madrid, 1877, pp. 13-14.

${ }^{154}$ Carta de Francisco de Villanueva para Inácio de Loyola (16. 03. 1552). In Epistolae Mixtae. Tomo II. Op. cit., p. 688.
} 
As relações com o núncio ficaram mais difíceis quando ele, sem consultar a Companhia (é o que afirma Francisco de Villanueva), resolveu entrar em acordo com o Arcebispo. Os termos do mencionado acordo foram os seguintes: em primeiro lugar, os jesuítas não receberiam cristãos novos, em segundo, a Companhia teria o seu Estatuto de Limpeza de Sangue, como as demais “religiões”155. Neste momento Francisco de Villanueva corrigiu o equívoco que havia cometido. O acordo levado a cabo com o núncio, dizia Francisco de Villanueva, foi o verdadeiro motivo que fez o Arcebispo suspender as perseguições feitas à Companhia. E não as "orações, sacrifícios e rogos” feitos a Deus, como havia informado na carta anterior ${ }^{156}$.

Quanto aos cristãos novos, que mesmo sendo “virtuosos e nobres” e de "boa gente”, não poderiam mais ser recebidos na casa da Companhia, escrevia Francisco de Villanueva como estivesse se lamentando por estas perdas. Entretanto, a Ordem poderia aproveitá-los, conforme sugestão dada por ele mesmo, transferindo-os para outras localidades onde não fossem perseguidos ${ }^{157}$.

Por outro lado, o núncio garantiu a Francisco de Villanueva que o acordo firmado entre ele e o Arcebispo fora provisório. Em outras palavras, Poggio não estaria obrigando a Companhia a obedecê-lo para sempre. O acordo ficaria em vigor até o Arcebispo “se acalmar”158.

Nesta missiva em análise continha uma notícia que pode esclarecer o desfecho do litígio da Companhia com o Arcebispo. Ele tentou conseguir do Príncipe (Felipe II, de quem ele era o preceptor) a proibição da Ordem receber cristãos novos ${ }^{159}$. Outro dado ainda mais difícil de entender: Francisco de

\footnotetext{
155 "Hallaban se algunos inconvenientes (em substituir Poggio), y así fuimos por donde su señoría quiso, ó pudo, y no por donde nosotros quisiéramos, especialmente en la palabra que el señor cardenal dio al arzobispo: lo uno, en que en esta casa no se recibiría persona que tuviese raza; lo otro, en que haría la Compañía lo hacen las otras religiones.” Idem, ibidem.

156 "Ya por otras creo terna $V$. P. entendido, como revocó el mandamiento que tenía dado, debajo de ste presupuesto que tengo dicho que el señor cardenal le prometió." Carta de Francisco de Villanueva para Inácio de Loyola (16. 03. 1552). Epistolae Mixtae. Tomo II. Op.cit., p. 688.

${ }^{157}$ Ver Carta de Francisco de Villanueva para Inácio de Loyola (16. 03. 1552). Epistolae Mixtae. Tomo II. Op. cit., pp. 688-89.

${ }^{158}$ Ver Carta de Francisco de Villanueva para Inácio de Loyola (16. 03. 1552). Idem, p.689.

159 "Sin embargo de lo dicho, la causa que el arzobispo da y a dado á muchos y al príncipe, es que hiciese S. A. que no recibiesen confesos en la Compañía...”. Carta de Francisco de Villanueva para Inácio de Loyola
} 
Villanueva informava ao Geral que havia recebido uma carta dele, cujo destinatário seria o núncio. Esta carta não foi localizada na "Monumenta Historica Societatis Jesu.” E por que Francisco de Villanueva não se referiu ao seu conteúdo ${ }^{160}$ ?

Entretanto, existe uma correspondência enviada por Inácio de Loyola para Francisco de Villanueva com a data de 01 de Junho de 1552. Nela encontra-se o desfecho da contenda com o Arcebispo Juan Martinez Siliceo. O Geral da Companhia de Jesus utilizou a seguinte argumentação: as graças espirituais - ou seja, as Bulas - concedidas pela Sé Apostólica à Companhia de Jesus tinham como objetivo ajudar as almas. Entretanto, este objetivo somente seria alcançado caso a Companhia realizasse a vontade do pastor delas (das graças espirituais). E, conforme Inácio de Loyola, o pastor por excelência, naquele momento era o Arcebispo de Toledo, Juan Martinez Siliceo. Tudo que se fizesse ao serviço de Deus, dizia Inácio de Loyola, estaria servindo ao Arcebispo. Portanto, continuava o Geral, a Companhia jamais deveria contrariar a vontade de Siliceo. Como ele poderia ser o pai e senhor da Ordem, era necessário ajudá-lo em tudo que favorecesse à Companhia e glorificasse a Deus. Sendo assim, a Ordem estava proibida de receber qualquer pessoa que contrariasse ao Arcebispo. Em outras palavras, Inácio de Loyola estava impedindo que os cristãos novos ingressassem na Companhia de Jesus em Toledo e toda Espanha ${ }^{161}$.

(16. 03. 1552). Idem, pp. 689-90. Nota-se que Francisco de Villanueva não disse nada a respeito da posição tomada pelo Príncipe. Esse silêncio sugere que não houve nenhuma interferência de Felipe II no desfecho da contenda. Porém, em uma carte anterior, de 14 de Janeiro de 1552, Antônio Araoz disse que o Príncipe ficou ao lado da Companhia de Jesus quando o Arcebispo conversou com ele a respeito do Estatuto de Limpeza de Sangue na Ordem. Ver Epistolae Mixtae. Tomo II. Idem, p. 656. Caso Antônio Araoz esteja correto (ou seja, que o Príncipe tenha, de fato, apoiado a Companhia), fica difícil entender as concessões feitas pelo núncio.

${ }^{160} \mathrm{Na}$ realidade tratava-se de três correspondências. Uma foi a supracitada. As demais eram duas cópias. Uma para o Cardeal (Poggio) e outra para o Arcebispo (J. M. Siliceo). A única que teve a autoria confirmada foi a original, de Inácio de Loyola: "Los traslados de las cartas que venían para el señor cardenal y el señor arzobispo recibimos, juntamente con la que de V. P. venía para el Cardenal. Carta de Francisco de Villanueva para Inácio de Loyola (16. 03. 1552). Epistolae Mixtae. Tomo II. Idem, p. 688.” Mas, como será visto logo a seguir, as três missivas podem ter sido escritas pelo Geral da Companhia de Jesus.

${ }^{161}$ Como este é um documento essencial para a problemática dos cristãos novos na Espanha, e além do fato de ser relativamente curto, será transcrito na íntegra:

"La gracia y amor de Xpo. nuestro señor sea siempre en nuestro favor i ayuda.

Considerando que las armas que nos da la sede apostólica de gracias espirituales entonces se usan más fructuosamente en ayuda de las ánimas, cuando concurrimos al mismo efecto con la voluntad del pastor propio de ellas, y que esto especialmente conviene observarse en el arzobispado de Toledo, donde el perlado 
Na mesma data em que foi escrita a carta para Francisco de Villanueva (01. 06. 1552) Inácio de Loyola redigiu outra para o Arcebispo Juan Martinez Siliceo. O Geral da Companhia de Jesus deixou claro que fez questão de demonstrar a todos o quanto reconhecia os benefícios recebidos do Arcebispo ${ }^{162}$. A forma encontrada por Inácio de Loyola para agradecer o que Juan Martinez Siliceo havia realizado para a Companhia foi rogar a Deus para que Ele o recompensasse com eterna e liberalíssima remuneração ${ }^{163}$.

Inácio de Loyola tomou uma atitude surpreendente. Garantiu para o Arcebispo que a Companhia de Jesus estava inteiramente ao seu dispor. E disse que ao servir-se da Ordem, Juan Martinez Siliceo estaria glorificando ainda mais a divina majestade ${ }^{164}$.

E como comprovação de que estava dizendo a verdade, e que considerava e iria sempre considerar o Arcebispo como “senhor e pai”, informou que já havia proibido a Companhia de receber, em toda a Espanha, quem pudesse contrariá-lo, ou seja, os cristãos novos ${ }^{165}$. Além disso, Inácio de Loyola comunicou a Juan Martinez Siliceo que a Companhia somente utilizaria as "graças concedidas pela Sé Apostólica” (a autorização, contida nas Bulas, para pregar, confessar e celebrar a missa) quando o Arcebispo considerasse conveniente usá-las para ajudá-lo nas

no dudo será servido de cuanto se hiciere en servicio de Dios nuestro señor, ame parecido por la presente avisaros, que en ninguna manera os apartéis de lo que hicieres sin ser la voluntad de S. Sría. Rma., así en el predicar como en la administración de los sacramentos, y los demás modos de ayudar á los próximos también, esperando que el señor arzobispo os a de ser padre y señor, y ayudaros en todo lo que para el aumento de la Compañía y gloria de Dios fuere conveniente, no querría que ninguna persona en todo ese reino se aceptase para la Compañía contra la intención y mente de S. Sría. Rma.; y así os lo encargo, y no haréis otra cosa." Carta de Inácio de Loyola para Francisco de Villanueva (01. 06. 1552). In Monumenta Ignaciana. Tomo IV. Madrid, 1906, pp. 261-62.

162 "Aunque sea cosa nueva mi escribir á V. S. Rma., no debe ser nuevo á nadie el tener y mostrar reconocimiento de los beneficios recibidos....” In Carta de Inácio de Loyola para o Arcebispo de Toledo (Roma, 01. 06. 1552). In Monumenta Ignaciana. Tomo IV. Idem, p. 263.

${ }_{163}$ Monumenta Ignaciana. Tomo IV. Op. cit., p. 263.

164 "nos tenga a todos por cosa enteramente suya en el Señor nuestro, y como de tal se sirva á mayor gloria de su divina majestad." Carta de Inácio de Loyola para o Arcebispo de Toledo (Roma, 01. 06. 1552). Idem, p. 264.

165 "Y en señal de que tenemos á V. S. Rma. Por señor e padre, y por tal le habemos siempre de tener, yo escribo á los nuestros que allá están, que en Alcalá ó en otra parte de ese reino no aceiten persona ninguna para la Compañía, que no sea conforme á la intención ó muestre de V. S. Rma." Carta de Inácio de Loyola para o Arcebispo de Toledo (Roma, 01. 06. 1552). Idem, ibidem. 
tarefas que Deus havia lhe dado. Por fim, o Geral da Companhia de Jesus reconhecia que as atitudes do Arcebispo em relação à Companhia ocorreram em função do seu “ânimo e zelo do serviço divino,” que estava convencido de que Juan Martinez Siliceo haveria de ser o protetor, senhor e pai da Companhia. Por fim, afirmou que o Arcebispo era o prelado que mais estava ajudando os jesuítas no reino espanhol ${ }^{166}$.

Afinal, o que pode ter acontecido para o Geral da Companhia de Jesus, Inácio de Loyola, ter se submetido, de modo irrestrito, à intolerância do Arcebispo da Igreja de Toledo, Juan Martinez Siliceo? Em outras palavras, afinal, por que Inácio de Loyola mudou, completamente, sua posição em relação ao Arcebispo?

O que dizem as fontes? Em torno de três meses antes da carta de Inácio de Loyola cedendo às imposições do Arcebispo, o cardeal e núncio J. Poggio, na condição de “juiz” da Companhia, havia aceitado todas as exigências de Juan Martinez Siliceo. Todavia, a Sé Apostólica, inclusive o Papa, apoiavam a Companhia de Jesus. Várias autoridades, civis e eclesiásticas, ficaram ao lado dos jesuítas, apesar das hesitações. Nenhum jesuíta aceitou aberta e facilmente, as exigências do Arcebispo. Houve, inclusive, a proposta de denunciá-lo ao Tribunal do Santo Ofício. Ocorreu um antecedente semelhante ao de Toledo, em Tíbule, no qual a Companhia saiu-se vitoriosa.

O núncio fez o acordo com o Arcebispo contrariando a Sé Apostólica e o Geral da Companhia de Jesus, ou ele foi orientado por Inácio de Loyola para ceder diante do Arcebispo? Esta pergunta procede porque na correspondência de Francisco de Villanueva de 10 de Março de 1552 consta a existência de uma carta, original, do próprio Loyola para o cardeal. E mais duas copiadas sem autoria especificada. A hipótese mais provável é que se trata, efetivamente, de duas cartas escritas por

\footnotetext{
166 " $Y$ aunque la sede apostólica nos aya concedido muchas gracias para ayudar á las animas, les escribo también que no usen de llas, sino en cuanto á V. S. Rma. y Illlma. Le parecerá deban usarlas para le ayudar á llevar alguna partecilla de la mucha carga que Dios N. S. ha puesto á V. S. Rma.; porque, como atribuyo al grande ánimo de V. S. Rma. y celo del divino servicio las cosas pasadas con nosotros antes de tener información de nuestro proceder, así, teniéndola, por el mismo me persuado que nos ha de ser verdadero protector y señor y padre V. S. Illma., ayudándonos más que ningún otro perlado en ese reino... ." Carta de Inácio de Loyola para o Arcebispo de Toledo (Roma, 01. 06. 1552). Idem, ibidem.
} 
Inácio de Loyola. Mas Francisco de Villanueva teria recebido a cópia e a original da que foi escrita para o núncio e a cópia da que seria enviada para o Arcebispo.

Portanto é possível concluir, de modo apriorístico, que na carta de Inácio de Loyola escrita para o núncio, encontravam-se os termos do acordo realizado entre este e o Arcebispo. Caso esta hipótese seja verídica, a decisão de aceitar as exigências feitas pelo Arcebispo partiu de Inácio de Loyola e não do núncio. Isso é o que sugerem as evidências. Mesmo que de modo indireto. Pois Inácio de Loyola foi enfático ao afirmar que o Arcebispo não possuía poderes para mudar as Constituições da Companhia de Jesus.

O fato do Arcebispo ter solicitado ao Príncipe a proibição da Companhia de Jesus receber cristãos novos parece não ser relevante. Porque, além de ter sido uma informação tardia (possível sinal de irrelevância), não houve nenhuma referência posterior a ela ${ }^{167}$.

Afinal, o que pode ter mudado a postura de Inácio de Loyola? As promessas feitas pelo Arcebispo à Companhia. Caso a Ordem adotasse os Estatutos de Limpeza de Sangue ou proibisse o ingresso de cristãos novos e transferisse os que já havia recebido, ela haveria de ser recompensada e ganharia assim um grande amigo, o Arcebispo. Esta foi a promessa feita pala autoridade máxima da Arquidiocese de Toledo. E foi esta promessa, muito provavelmente, o motivo pelo qual a Companhia de Jesus compactuou com o anti-semitismo do Arcebispo de Toledo, Juan Martinez Siliceo.

Na essência o comportamento de Inácio de Loyola em relação à intolerância do Arcebispo Juan Martinez Siliceo não diferiu do comportamento de Simão Rodrigues quando ele redigiu o regimento do Colégio da Companhia em Coimbra.

\footnotetext{
${ }^{167}$ Dois dias após ter escrito para o Arcebispo aceitando todas as suas exigências - ou seja, em 03. 06. 1552 Inácio de Loyola escreveu para o Príncipe Felipe II lhe agradecendo todos os favores feitos à Companhia, especialmente favoreceu a Ordem diante do Arcebispo Juan Martinez Siliceo: “... me pareció escribir esta, y por ella himildemente besar las manos de V. A. por la merced que a todos nos ha jecho (sobre tantas otras) favoresciendo nuestras cosas con el señor arzobispo, como protector y señor verdadero." In San Ignacio de Loyola. Obras Completas. IV Edição, Madrid, 1982, p.825. Inácio de Loyola poderia está se referindo à negação de Felipe II ao pedido do Arcebispo para que o Príncipe proibisse a Companhia de receber cristãos
} 
Ambos discriminaram os cristãos novos. Cada um a seu modo; porém, quando tomaram suas decisões, a mesma mentalidade predominou: agir conforme as conveniências locais. Decidir em função destas conveniências. Portanto, neste cálculo, ignoravam-se os princípios, as normas, as regras. O que prevalecia era a lógica das “vantagens comparativas”168.

Em 13 de Julho de 1553 Gaspar Loarte e Diego de Guzman escreveram para Antônio Araoz reclamando por não terem sido admitidos na Companhia de Jesus. Eles deram a entender que o motivo teria sido por serem cristãos novos ${ }^{169}$. Antônio Araoz negou que este tenha sido o motivo. A causa, disse A. Araoz, foi o fato de um

novos. Caso este não tenha sido o motivo dos agradecimentos, pode ter sido um gesto cordial ou, digamos, diplomático.

${ }^{168}$ Antônio Astrain atribuiu a conclusão da contenda entre a Companhia de Jesus e o Juan Martinez Siliceo, ao fato do Arcebispo de Toledo ter ficado isolado em sua política anti-semita. Considerou uma vitória da Companhia a forma pela qual se dirimiu a querela. E enfatizou o apoio do Príncipe Felipe II à Companhia de Jesus. Ver ASTRAIN, Antônio. Historia de la Compañía de Jesus en la Asistencia de España. Tomo I (1540-

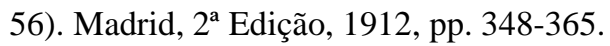

Foi visto anteriormente que o Arcebispo solicitou ao Príncipe que "cobrasse" da Companhia a adoção do Estatuto que já estava em vigor na Arquidiocese. Além disso, Juan Martinez Siliceo era mestre, confessor e capelão de Felipe II e foi pelo Príncipe indicado para o posto de Arcebispo de Toledo. Quanto aos demais apoios, também foi visto que, apesar de terem existido, foram inconsistentes. António Astrain concebeu a exigência feita pelo Arcebispo para a Companhia de Jesus adotar o Estatuto de Limpeza de Sangue como “uma questão acessória.” Entretanto, ele ignorou um dado fundamental. No encontro ocorrido entre os padres Francisco de Villanueva e Miguel de Torres com o Arcebispo em 15 de Novembro de 1551, Juan Martinez Siliceo disse que não tinha nada contra a Companhia. Mas algo o preocupaba seriamente: Dios, que él no tenía enemistad con la Compañía, ni la quería mal; pero que él hacía esto porque en la Compañía se hiciese el estatuto que él a hecho en la iglesia de Toledo, y que él pretendía que no hubiese cura ni beneficiado que fuese de esta casta (Carta de Francisco de Villanueva para Inácio de Loyola. In Epistolae Mistae. Tomo II. Op. cit., p. 625). O que ele queria, portanto, era que a Ordem adotasse o Estatuto de Limpeza de Sangue e que não recebesse cristãos novos. Outro fato relevante, omitido por Antônio Astrain, foi o seguinte: o núncio garantiu ao Arcebispo que a Companhia de Jesus não receberia mais cristãos novos e que teria o seu Estatuto de Limpeza de Sangue (Ver Carta de Francisco de Villanueva para Inácio de Loyola, 16. 03. 1552. Op.cit. p. 688). Aliás, os cristãos novos já havia se tornado um problema para Companhia de Jesus na Província espanhola desde Novembro de 1549, senão antes. È o que comprova uma a carta de Antônio Araoz (Provincial) escrita em 5 de Novembro de 1549 para Juan de Polanco: "Entre nuestro devotos hay scisma, unos diziendo que cebríamos traer señal diferente de los otros clérigos, los otros diziendo que no. Y lo mismo sobre recibir cristianos. Nuevos.”. In Epistolae Mixtae. Tomo II. Idem, p. 314. A inferência não pode ser outra, senão a de que a "vitória" foi do Arcebispo, pois conseguiu o que queria, ou seja, impedir o ingresso dos cristãos novos na Companhia de Jesus em toda a sua Arquidiocese. Aliás, como já foi visto, Inácio de Loyola garantiu ao Arcebispo que sua Ordem não receberia cristãos novos apenas na Arquidiocese de Toledo, mas em todo o reino espanhol.

${ }^{169}$ Epistolae Mixtae, Tomo III. Matriti, 1900. pp. 392-93. 
amigo deles ter sido preso pelo Tribunal do Santo Ofício ${ }^{170}$. Ou seja, automaticamente a Inquisição considerava ambos suspeitos.

É de supor que tanto Gaspar Loarte quanto Diego de Guzman não ingressaram na Companhia de Jesus porque a Ordem havia se comprometido com o Arcebispo de Toledo em não receber mais os cristãos novos em todo o reino espanhol. Inclusive, este é um dado novo, o Provincial Antônio Araoz também se comprometeu com o Arcebispo em obedecê-lo em tudo ${ }^{171}$. Mesmo assim, dizia Francisco de Villanueva, Juan Martinez Siliceo continuava pressionando os jesuítas. A solução para encerrar definitivamente este problema, sugerido por Francisco de Villanueva a Inácio de Loyola, foi o afastamento da Ordem dos cristãos novos recebidos. $^{172}$

Não foi encontrada nenhuma correspondência com a resposta de Inácio de Loyola à sugestão de Francisco de Villanueva a respeito da “expulsão” dos cristãos novos que já haviam ingressado na Companhia em Alcalá. Mas Inácio de Loyola respondeu indiretamente à sugestão. Na carta de 14. 08.1553 enviada para Antônio Araoz, provincial na Espanha, Inácio de Loyola deixou claro que a Companhia de Jesus não deveria receber os conversos quando alguém da corte ou o próprio rei fosse contra o ingresso dos mesmos ${ }^{173}$. Portanto, se deduz que não deve ter permanecido nenhum jesuíta cristão novo em Alcalá de Henares, já que Juan Martinez Siliceo, além de ser o Arcebispo da Igreja primaz da Espanha, era também um homem da corte (preceptor de Felipe II).

\footnotetext{
${ }^{170}$ Ver carta de Antônio Araoz para Inácio de Loyola (25. 10. 1553). In Epistolae Mixtae. Tomo III, idem, p. 621.

171 “Al arzobispo se le dio todo lo que él quiso, y no sólo el cardenal, pero el Padre provincial de palabra..." Carta de Francisco de Villanueva para Inácio de Loyola (20. 09. 1552). In Epistolae Mixtae. Tomo II. Idem, p. 787.

172 "Emosle pedido nos diesel a puerta, y suplicado sea servido de que pongamos sacramento. No lo uno ni lo otro se a podido acabar con él, aunque sabe tenemos gracias para poner. Creo yo, á lo que del siento, que se acabaría con él que no tratase mal las cosas de la Compañía, con echar V. P. los que en ella ay que tengan raza" (grifo nosso). Idem, ibidem.

173 "Del no aceptar cristianos nuevos no se persuade N. P. seria Dios servido. Pero bien le parece se debería de tener con los tales más circunspección. Si allá por los humores de la corte ó del rey no pareciere se deban admitir, envíense acá, siendo buenos suppósitos como ya está escrito otras vezes; que acá no se mira tan al sotil de qué raza sea el que se ve ser buen suppósito, como tampoco basta, para que uno se acepte, la
} 
Após esta análise minuciosa, na qual ficou esclarecido o modo pelo qual a Companhia de Jesus solucionou, na prática, a questão dos cristãos novos na Arquidiocese de Toledo e, por extensão, em toda a Espanha, retornemos às normas jesuíticas relativas aos conversos.

\section{ÚLTIMA NORMA ANTES DA APROVAÇÃO DAS CONSTITUIÇÕES}

Em 1556 surgiu mais um documento legislando sobre o ingresso dos cristãos novos na Ordem. Isso comprova que a questão dos conversos na Companhia de Jesus, desde 1546, era um assunto normativo relevante para a Ordem, e que além disso, não competia aos Colégios e casas da Companhia tratar deste tema em suas regras. O conteúdo é praticamente o mesmo do Examen Cum Declarationibus de 1546 e 1550. Apenas ocorreu uma mudança nos termos utilizados. Trocou-se a expressão cristãos velhos por cristãos antigos, e cristãos novos por cristãos modernos: "Se vem de cristãos antigos ou modernos." 174

Pode até ter havido algum motivo relevante para a Companhia efetuar estas mudanças, mas a hipótese a ser aqui considerada é a de que não houve, no documento de 1556, nenhuma mudança semântica significativa que expressasse alguma modificação considerável na política da Ordem em relação ao ingresso de cristãos novos ${ }^{175}$.

No que concerne ao aspecto regimental, conforme o texto de 1556, os cristãos novos continuaram a ingressar na Companhia de Jesus, apesar da restrição implícita na própria pergunta (“Se vem de cristãos antigos ou modernos”). Isso quer dizer que o grupo que era favorável à presença dos descendentes dos judeus foi majoritário. A

nobleza, si las otras partes no concurren.” Carta de Juan de Polanco (em nome de Inácio de Loyola) para Antônio Araoz (14. 08. 1553). In Monumenta Ignatiana, Séries I, Tomo V. Madrid, 1907, p. 335.

174 "Si viene de christianos antiguos o modernos". In Monumenta Ignatiana, Series Tertia, Sancti Inatii de Loyola, Constitutiones Societatis Jesu, Tomus Secundus, Textus Hispanus. Textus B, CA, 1556. Roma, 1936, p. 31.

175 Pierre-Antoine Fabre supôs que a mudança ocorreu devido ao incômodo causado pelo fato do antigo Testamento ser chamado de Velho Testamento (até o século XVII) e pelo paradoxo de designar os fiéis do Novo Testamento de cristãos velhos. Ver Fabre, Pierre-Antoine. Op. cit. p.878. 
pergunta também expressa a correlação de forças entre os jesuítas tolerantes à presença dos cristãos novos na Companhia de Jesus e os que não a toleravam.

\section{A APROVAÇÃO DAS CONSTITUIÇÕES E OS CONVERSOS}

As Constituições da Companhia foram aprovadas em 1558 pela Primeira Congregação Geral da Ordem. Em relação ao texto de 1556, ocorreu mais uma pequena mudança no item que tratou da entrada dos cristãos novos. Onde estava escrito cristãos modernos lê-se cristãos novos. Portanto, a pergunta a ser feita ao postulante, inscrita nas Constituições foi a seguinte: "Se descende de cristãos antigos ou de cristãos novos."

Algumas conclusões se extraem da aprovação das Constituições no que diz respeito aos conversos. A proposta de incluir a questão dos cristãos novos nas Constituições foi vitoriosa (lembrando que as Constituições foram criadas para serem, o tanto quanto fosse possível, permanentes). O que isso significou para os cristãos novos? Ao ser considerado um tema "universal" (ou seja, objeto das Constituições), a questão dos cristãos novos não poderia ser incluída nos regimentos dos colégios, como aconteceu no Colégio de Coimbra.

Os jesuítas menos intolerantes com os conversos prevaleceram em relação aos mais intolerantes. O resultado da correlação de forças entre ambos foi o seguinte: apesar da ascendência judaica do candidato ter continuado sendo uma preocupação para a Companhia de Jesus, o fato de ser descendente de judeu não impediu o seu ingresso legal na Ordem. Contudo, ao incluir a pergunta nas Constituições, a Companhia dificultou o ingresso dos conversos. Foi uma forma encontrada para conciliar as posições antagônicas. O recebimento dos cristãos novos não estava proibido nem tampouco facilitado. Pode se dizer, portanto, que os menos intolerantes e os mais intolerantes saíram "vitoriosos”. E para o cristão novo foi uma "vitória”, se compararmos com o que aconteceu no Colégio de Coimbra (a 
exclusão). E foi, ao mesmo tempo, uma “derrota”, pois a pergunta poderia ter sido retirada, como sugeriu Alfonso Salmerón, tornando a entrada dos cristãos novos na Companhia de Jesus completamente livre de qualquer impedimento ou obstáculo.

Aprovadas as Constituições, encerrou-se um ciclo de elaboração de normas, regras e regimentos na Companhia de Jesus. A partir de 1558, ano da sua aprovação, a questão dos cristãos novos, no que diz respeito ao aspecto regimental, permanecerá estável até a última década do século XVI. Entretanto, a nível local (em Goa) o tema dos cristãos novos na Companhia voltará a ser objeto de discussão. Inclusive, foi elaborada norma relativa à questão. Essa problemática será tratada logo a seguir.

\section{$\underline{\text { A VULNERABILIDADE DOS CRISTÃOS NOVOS }}$}

No que concerne aos cristãos novos, as normas da Companhia de Jesus (Constituições e regimentos) elaboradas até 1558 expressavam o grau em que eles eram tolerados ou intolerados nos lugares onde havia a presença da Ordem. Entretanto, como já foi considerado, houve um caso em que a intolerância surgiu dentro da própria Companhia. Ocorreu em Goa, quando o padre jesuíta Antônio Gomes foi contra a eleição do também jesuíta Henrique Henriques para o cargo de superior regional da Costa da Pescaria porque ele era cristão novo.

O voto de obediência podia ser desrespeitado se o interesse da Companhia em determinado momento e lugar fosse considerado mais importante do que o referido voto. Foi o que aconteceu, por exemplo, no Colégio de Jesus - em Coimbra. O seu regimento contrariou as "Constituições" de 1541 quando proibiu que o Colégio recebesse cristãos novos.

As regras já estabelecidas tratando dos cristãos novos também podiam ser ignoradas em função dos ganhos imediatos e a longo prazo que a Companhia de Jesus poderia auferir. Foi exatamente o que ocorreu na Arquidiocese de Toledo com

\footnotetext{
${ }^{176}$ Constituições da Companhia de Jesus e Normas Complementares.Op. cit., p.47.
} 
as concessões realizadas por Inácio de Loyola ao Arcebispo Juan Martinez Siliceo e em todo o reino português quando Inácio de Loyola delegou ao rei, D. João III, o poder de impedir o ingresso dos cristãos novos na Província Portuguesa.

Em suma, até o período pesquisado (1558) a situação dos cristãos novos na Companhia de Jesus era totalmente instável. Eles estavam vulneráveis a qualquer pressão, seja dentro da própria Ordem ou fora dela. Apesar dessa condição de total vulnerabilidade, houve um espaço para eles na Companhia. Não em todos lugares, mas naqueles onde a intolerância com os descendentes dos judeus não fosse intensa, como em Roma, por exemplo.

Portanto, assim foram tratados os cristãos novos pela Companhia de Jesus desde a sua fundação (1540) até 1558 (ano da aprovação das Constituições pela primeira Congregação Geral): sujeição ao que a Companhia considerava mais conveniente. Em outras palavras, a Ordem não lhes deu, na prática, nenhuma garantia legal ou formal. Em última instância poderiam recorrer ao Papa. Caso os requerimentos fossem aceitos pelo pontífice, o Prepósito Geral poderia aceitá-los ${ }^{177}$.

\footnotetext{
177 Já vimos que as Constituições de 1558 previam que o candidato com impedimento poderia ter a oportunidade de ingressar na companhia. Bastava que ele conseguisse autorização do Papa. Caso fosse concedida, o Geral poderia recebê-lo. Como ser cristão novo não era um impedimento legal, mas muitas vezes efetivo, é provável que os conversos tenha recorrido ao Papa quando, por algum motivo, não foram recebidos.
} 


\section{CAPÍTULO IV. JESUÍTAS DE ORIGEM JUDAICA NO ORIENTE.}

As missões da Companhia de Jesus no Oriente começaram em Maio de 1542 com a chegada em Goa $^{178}$ de Francisco Xavier ${ }^{179}$ e mais dois novos membros da Ordem que o acompanhavam, Francisco Mansilhas e Paulo Camerte ${ }^{180}$.

O primeiro jesuíta cristão novo enviado para o Oriente foi Henrique Henriques $^{181}$. Ele aportou na cidade de Goa em setembro de 1546, quando foi recebido por Francisco Xavier, que logo o enviou para missionar na Costa da Pescaria.

Nicolao Lancillotte ${ }^{182}$ o escolheu para ser o Superior Regional ${ }^{183}$ daquela Costa $^{184}$. Entretanto, inicialmente Henrique Henriques recusou a escolha porque, caso aceitasse a indicação - dizia ele - os portugueses causariam escândalo ao verem um cristão novo ocupando um cargo que deveria ser exercido por um cristão velho $^{185}$. Ao ouvir tais argumentos Nicolao Lancillotte reconheceu que sua escolha

${ }^{178}$ Goa foi conquista pelos portugueses em 1510. Afonso de Alburqueque, comandante dos portugueses, aliou-se aos hindus e tomou a cidade, a qual era controlada pelos muçulmanos. Neste mesmo ano Goa se tornou a capital do Estado Português da Índia.

${ }^{179}$ Estudou em Paris, onde conheceu Inácio de Loyola. Foi um dos fundadores da Companhia de Jesus. Chegou como superior e posteriormente tornou-se Provincial da Índia (Inácio de Loyola lhe concedeu a patente de Provincial em Dezembro de 1549, mas Francisco Xavier somente pôde recebê-la em 1552. Missionou em várias localidades do Oriente, chegando até o Japão (15.08.1549). Faleceu na Ilha de Sanchoão, quando estava a caminha da China (03.12.1552). Foi canonizado em 1622. É o Padroeiro dos missionários.

${ }^{180}$ Há informações de que, na realidade, Francisco Mansilhas e Paulo Camerte ficaram em Moçambique.

181 Já sabemos que Henrique Henriques foi admitido na Companhia de Jesus por Simão Rodrigues.

182 “... morrendo o padre Antônio Criminal, mandei dar o cargo ao Padre Henrique .... ." Carta de Nicolao Lancillotte para Inácio de Loyola. Ceilão, 06.01. 1551. Documenta Indica II. Edidit Ioseph Wicki S. I. Romae, Apud “Monumenta Historica Soc. Iesu”, 1950, p. 147.

${ }^{183}$ O Superior Regional era o representante imediato do Superior “Geral.” Antes de criar uma nova Província, era eleito um Superior (digamos Superior Geral), que geralmente era escolhido para ser o Provincial, como o foram os casos de Simão Rodrigues em Portugal e Francisco Xavier em Goa.

${ }^{184}$ O Diccionario Histórico de la Compañía de Jesús. Biográfico-Temático diz, equivocadamente, que “os outros jesuítas o elegeram”. Ver Diccionario Histórico de la Compañía de Jesús. Biográfico-Temático. Op. cit., vol. I, p.177.

185 "Ele se recusou tanto de ser Superior, dando por razão que ele era casta de cristãos novo, que os portugueses o escandalizaria em ver como um cristão novo tivesse cargo dos outros padres... "." Carta de Nicolao Lancillotte para Inácio de Loyola. Ceilão, 06.01. 1551. Documenta Indica II. Idem, p. 147. 
poderia criar problemas. Concordou com Henrique Henriques. Ao mesmo tempo, ficou impressionado com a humildade do cristão novo.

Assumiu o cargo Antônio Criminal, que logo veio a falecer (1549). Nicolao Lancillotte, que havia indicado Antônio Criminal, nomeou Henrique Henriques +ela segunda vez para ocupar a vaga deixada após a morte do padre Antônio Criminal. Sua escolha decorreu por considerá-lo o mais preparado para assumir o cargo ${ }^{186}$. Este foi o motivo pelo qual assumiu as consequências que sua opção poderia causar. Desta vez Henrique Henriques sentiu-se mais seguro e aceitou a indicação.

\section{INTOLERÂNCIA COM HENRIQUE HENRIQUES}

A reação contrária à escolha de Henrique Henriques para o cargo de Superior Regional da Costa da Pescaria não tardou a se manifestar, como havia previsto o cristão novo em questão. Antônio Gomes, reitor do Colégio de Goa e Procurador das Missões fora de Goa, se dirigiu a Nicolao Lancillotte dizendo que ele "dava cargo a quem não é nem pode ser da Companhia."187

Antônio Gomes, dizia Nicolao Lancillotte, citou uma série de razões contrárias à eleição de Henrique Henriques, todas ignoradas por Nicolao Lancillotte. Somente anularia a escolha de Henrique Henriques, argumentou Nicolao Lancillotte, caso recebesse ordem de Inácio de Loyola ou de Francisco Xavier. Além disso, justificou a escolha do cristão novo dizendo que se fosse um grave erro recebê-lo, como dizia Antônio Gomes, Francisco Xavier não teria dado cargo a Afonso de Castro em Maluco. Já que ambos, além de serem cristãos novos, foram

\footnotetext{
186 “ mandei dar o cargo ao Padre Henrique, ... por não ser lá nessa terra ninguém que seja para ter cargo senão ele.” Carta de Nicolao Lancillotte para Inácio de Loyola. Ceilão, 06.01. 1551. Documenta Indica II. Op. cit., p. 147.

${ }^{187}$ Idem, ibidem.
} 
franciscanos ${ }^{188}$. Mas havia uma diferença entre os dois, Afonso de Castro não era tão competente quanto Henrique Henriques ${ }^{189}$, argumentou Nicolau Lancillotte.

Francisco Xavier confirmou a escolha feita por Nicolau Lancillotto. ${ }^{190}$ Inácio de Loyola, além de ter aceitado que Henrique Henriques assumisse o cargo de Superior Regional da Pescaria, o dispensou de fazer uma petição ao papa autorizando a sua permanência na Ordem ${ }^{191}$. O superior da Companhia de Jesus tomou esta atitude porque, segundo ele, as Constituições da Companhia de Jesus ainda não estavam concluídas, querendo dizer com isso que nenhum dos impedimentos estavam em vigor.

Ao receber os apoios de Francisco Xavier e, principalmente, de Inácio de Loyola, Henrique Henriques foi mantido não somente na Companhia, mas também no cargo de Superior Regional da Costa da Pescaria. Inclusive em nove de Janeiro de 1554 foi promovido por Inácio de Loyola a coadjutor. Entretanto, nunca recebeu a patente ${ }^{192}$.

Em 1552 Antônio Gomes foi enviado para Roma por ordem de Inácio de Loyola. Faleceu no trajeto quando o navio que o transportava naufragou ${ }^{193}$.

\footnotetext{
${ }^{188}$ Estariam impedidos de ingressar na Companhia conforme o VI impedimento: "si aluno hubiese tomado hábito de religión de frailes o clérigos, viuiendo algún tiempo com ellos en obediençia, hauiendo hecho professión o no la hauiendo hecho."

${ }^{189}$ Sobre a formação de Henrique Henriques o padre Melchior Carneiro escreveu para o Geral Diego Lainez informando que ele sabia latim, teologia e artes que correspondia às sete artes liberais: gramática, retórica, lógica ou dialética (trivium); aritimética, astronomia, geometria - que incluía geografia e história natural - e música (quadrivium). Ver Documenta Indica IV (1557-60). Edidit Ioseph Wicki S. I. Romae, Apud "Monumenta Historica Soc. Iesu, 1956, p.429.

${ }^{190}$ Ver Diccionario Histórico de la Compañía de Jesús. Biográfico-Temático. Op. cit., vol. I, pp.177-178.

191 "Quanto ao P. Henrique Henriques, já nos anos passados, se bem me lembro foi aceito na Companhia, e pode ter o cargo que le deram como membro dela, e não é necessária petição para o Papa; porque não sendo concluídas as Constituições, podemos reter na Companhia os que já estão nela como aquele impedimento.” Carta de Inácio de Loyola para Nincolao Lancillotte. Roma, 27. 01. 1552. In . Documenta Indica II. Op.cit., p. 312.

192، Em dezembro de 1554 recebi uma de Vossa Paternidade escrita a 9 de Janeiro; a nau invernou em Moçambique e por isso tardou tanto. Nela me diz que (se se bem lembra) me há mandado huma patente para admitir-me na Companhia como coadjutor dela, a qual patente ainda até agora cá não vi.” Excerto da Carta de Henrique Henriques para Inácio de Loyola. Cochim, 20. 01. 1555. In Documenta Indica III. 1553-57). Edidit Ioseph Wicki S. I. Romae, Apud "Monumenta Historica Soc. Iesu, 1954, pp. 235-36.

${ }^{193}$ Ver O’Neill, Charles E. S. I., e Domínguez, Joaquín Ma S. I. Diccionario Histórico de la Compañia de Jesús Biográfico-Temático. Op. cit., Vol. II, p. 1771.
} 
Por que Inácio de Loyola manteve Henrique Henriques no cargo de Superior Regional, ao mesmo tempo em que afastou Antônio Gomes das missões orientais? Dois motivos podem ter influenciado a decisão do Geral da Companhia de Jesus. Em primeiro lugar, Henrique Henriques era um jesuíta obediente, humilde e submisso. Essas características garantiam ao Geral e ao Provincial o controle total sobre suas atividades. Por ter uma personalidade oposta, Antônio Gomes sempre agia com um grau de autonomia inadmissível para a Ordem. Por isso foi punido. O segundo motivo provável foi que, além de Antônio Gomes, nenhum outro jesuíta se manifestou contra Henrique Henriques. Isso não quer dizer, necessariamente, que não havia inacianos no Oriente contrários à presença de cristãos novos em cargos de comando na Companhia de Jesus naquele momento. Eles podiam estar lá, mas não se manifestaram. O fato é que, isolado ou não, no caso de Henrique Henriques o anti-semitismo de Antônio Gomes foi derrotado ${ }^{194}$.

Talvez por estar consciente da sua condição de cristão novo, ou seja, por consciência de que a qualquer momento poderia ser afastado da Ordem ou sofrer perseguições por parte dos padres e irmãos jesuítas e dos cristãos velhos leigos, Henrique Henriques sempre comportou-se com humildade e subserviência diante dos seus superiores hierárquicos. Sua devoção ilimitada e incondicional às missões jesuítas pode expressar não somente a sua vulnerabilidade, sua total dependência em relação à Companhia de Jesus, mas também a dependência e vulnerabilidade de todos os demais cristãos novos que ingressaram na Companhia de Jesus.

"Sou eu tão devoto da Companhia que, ainda que me deitassem fora, não saberia fazer outra coisa, senão ir buscar Mestre Francisco no Japão. $O p .^{e}$ Nicolao me disse que $V$. R. Ihe escrevera que suplicasse ao Papa sobre o meu impedimento; com esta carta vai a petição. Por amor

\footnotetext{
${ }^{194}$ Anteriormente vimos a "manobra” feita por Francisco Xavier para satisfazer o anti-semitismo de Antônio Gomes.
} 
de Deus que ordene $V$. R. isso lá para consolação desta alma mesquinha, que tanto ama a Companhia e os servos dos servos da Companhia." 195

Em janeiro de 1551 Nicolao Lancellotte confirmou a grande devoção do seu protegido que, conforme suas palavras, mesmo quando estava doente era o exemplo a ser seguido por todos no serviço a Deus ${ }^{196}$.

Não tardou muito para que Henrique Henriques voltasse a sofrer discriminações. Em Dezembro de 1556 ele escreveu para Inácio de Loyola lamentando o que falavam a seu respeito ${ }^{197}$.

A partir de 1559 havia dois grupos. Um favorável a Henrique Henriques, e outro que, ao mesmo tempo em que reconhecia suas qualidades pessoais e os méritos do seu trabalho, não lhe poupava críticas ${ }^{198}$.

Um dos jesuítas que mais elogiou Henrique Henriques foi Nicolao Lancillotto. Considerava-o "prudente, discreto, virtuoso, grande pregador", e assegurou que "tudo que escreve é verdade"199. O provincial Antônio de Quadros

${ }^{195}$ Carta de Henrique Henriques para Inácio de Loyola. Cochim, 09. 01. 1550. In Documenta Indica II, Op., cit., p. 5.

196 "Ficou muito doente do estômago e da cabeça, e porém com todas estas coisas e doenças, que ele tem, prouvera a Deus que todos os que estão sãos fizessem a metade do que ele faz, serviço a Deus. Aprendeu o malabar, fez uma gramática e traduções para esta língua, é um pregador incansável, tem disputas com gentios, cristãos e mouros.” Carta para Inácio de Loyola. Ceilão, 06. 01. 1551. In Documenta Indica II. Op. cit., pp. 145-46.

${ }_{197}$ "Quando vejo o fruto que se perde ao me tratarem como suspeito e falarem de mim coisas (que eu, por outros pecados que contra a divina Majestade tenho feito, bem mereço) do que se segue parecer-me alguma ou muita desconsolação, consolo-me lembrando-me de Sancta Catarina de Sena que, indo a Florença para fazer as pazes entre os florentinos e o papa Gregório XI, foi tão grande o ódio que muitos dos florentinos lhe tiveram, que estavam para matá-la e com muita dificuldade se achou um seu devoto que a recolheu em casa. Consolo-me também ao me lembra que os males de culpas que Deus permite é para deles tirar bens, e assim muitas vezes, onde maiores males de culpa há, daí tira nosso bom Deus maiores bens. E assim vendo eu os males grandes que depois destes bandos têm sucedido, e que ao presente não somente não podemos ir com o fruto avante, mas que nos contentaríamos com vermos os cristãos como agora há dois anos, quero dizer, que, posto que nada houvessem aproveitado espiritualmente adiante, ao menos não caíssem no que dantes eram." Excerto da Carta de Henrique Henriques para Inácio de Loyola, 31. 12. 1556. In Documenta Índica, vol. III. Op. cit.,, pp. 595-96.

198 Jesuítas favoráveis a Henrique Henriques: Nicolao Lancillotto, Baltasar Nunes, Fr. Aires Brandão, Emmanuel Fernandes e Melchior Carneiro (o único que fez referência à sua ascendência judaica, mas sem estigmatizá-lo por isso). Inacianos críticos a Henrique Henriques: M. Nunes Barreto, Francisco Rodrigues e Antônio Quadros. Quanto ao grupo que apoiava Henrique Henriques ver Documenta Indica II, pp. 284-85, 373; Documenta Indica III. Idem, pp. 186, 192-93 e 276-77 e Documenta Indica IV. Op. cit., p. 420. Os críticos ao cristão novo encontram-se na Documenta Indica IV, pp. 383, 398 e 516.

${ }^{199}$ Carta de Nicolao Lancillotte para Simão Rodrigues. Coulão, 28. 10. 1552. In Documenta Indica II. Op. cit., p. 373. 
(1559-72) foi um dos seus críticos. Em 1559 ele escreveu para o Geral Diego Lainez dizendo que H. Henriques era "muito virtuoso, e muito firme na vocação, tem medíocres letras, não prega. É prudente mas com muitos escrúpulos, muito indeterminado em tudo."200

\section{A DISSEMINAÇÃO DO ANTI-SEMITISMO ENTRE OS JESUÍTAS}

Cerca de quatro anos após a derrota do cristão velhos Antônio Gomes (1555), começaram a surgir sinais de um movimento articulado e aberto na Companhia de Jesus no Oriente contra os cristãos novos jesuítas que lá missionavam. Os indícios apontam que este movimento se manifestou nas críticas feitas ao Superior Regional da Costa da Pescaria, Henrique Henriques.

Um fato novo merece ser aqui registrado. Foi em 1555 que chegaram em Goa as Constituições. E, como já foi visto, nelas se encontrava a pergunta que discriminava os candidatos de ascendência judaica. Esse fato pode ter reacendido ou impulsionado o sentimento "anti-converso" nas missões orientais da Companhia de Jesus.

O padre Antônio de Heredia escreveu para a Província portuguesa (1561?) informando que causava escândalo para algumas pessoas o fato de alguns cristãos novos terem cargos de mando na Companhia de Jesus, e cita o caso de Henrique Henriques como exemplo ${ }^{201}$.

Apesar das críticas que lhe foram dirigidas e da oposição à sua indicação para dirigir as missões na Pescaria, Henrique Henriques se manteve no cargo, mas não durante toda a sua vida. Em 1576 foi afastado, um ano depois da Província de Goa ter proibido o ingresso de cristãos novos. De 1576 até a sua morte viveu praticamente no ostracismo, restringindo suas atividades missionárias a escrever obras cristãs em língua tamil ${ }^{202}$.

\footnotetext{
${ }^{200}$ Carta de Antônio de Quadros para Diego Lainez. Goa, 18. 11. 1559. In Documenta Indica IV, p. 398.

201 "Alguns cristãos novos mandão na Companhia na Índia. Não se edificão algumas pessoas disso, antes se escandalizam por correrem os tempos como correm.” In Documeta Indica V (1561-63). Edidit Ioseph Wicki S. I. Romae, Apud "Monumenta Historica Soc. Iesu,, 1958, p. 201.

${ }^{202}$ Ver O’Neill, Charles E. S. I., e Domínguez, Joaquín Mª S. I. Op. cit., Vol. I, p. 178.
} 
Afonso de Castro era cristão novo por parte de pai. Apesar de considerá-lo menos capaz do que Henrique Henriques, Nicolao Lancillotto reconheceu suas qualidades. Foi escolhido por Francisco Xavier para ser o superior das missões nas Molucas em 1549 - mesmo ano da promoção de Henrique Henriques ${ }^{203}$. Já conhecia Simão Rodrigues e Francisco Xavier antes de ir para o Oriente ${ }^{204}$. Também foi confirmado como membro da Companhia por Inácio de Loyola na mesma data em que confirmou Henrique Henriques na função de Superior Regional da Costa da Pescaria $(1552)^{205}$.

Em 1555 sucedeu o superior Juan de Bera nas missões nas ilhas do Moro. De acordo com a documentação consultada, apesar de Afonso de Castro ser cristão novo, ter usado o hábito dos franciscanos e ocupado cargos de comando na Companhia de Jesus, ele não foi discriminado por nenhum jesuíta cristão velho. Entretanto, alguns documentos afirmam que houve um grave desentendimento entre ele e o cristão novo Antônio Vaz. De acordo como o padre Antônio de Heredia, Antônio Vaz forjou um documento no qual seria ele e não Afonso de Castro o superior das missões nas ilhas Molucas ${ }^{206}$. O "Diccionario Histórico de la Compañia de Jesús Biográfico-Temático" diz apenas que Antônio Vaz pretendia o superiorato $^{207}$. Nenhum dos demais jesuítas que escreveram sobre o caso (os padres Francisco Rodrigues, Antônio de Quadros e Francisco Cabral) se referiram ao documento falso citado pelo padre Antônio de Heredia.

Antônio de Heredia, em um tom malicioso, constatou que as desavenças ocorridas entre Afonso de Castro e Antônio Vaz "não fora escândalo tanto como foi

Henrique Henriques faleceu na Índia em 1602.

203 "Muito bom filho e muito bom mancebo... Estou muito edificado dele... Deve ser recebido? Francisco Xavier o ordenou sacerdote e mandou-o para Maluquo (Molucas) e por ser discreto e virtuoso lhe deu cargo de todos aqueles que lá andam.” Carta de Nicolao Lancillotte para Inácio de Loyola. Ceilão, 06.01. 1551. In Documenta Indica II. Op. cit., p. 146.

${ }^{204}$ Ver O’Neill, Charles E. S. I., e Domínguez, Joaquín Mª S. I. Op. cit., Vol. I, p. 707.

205 "E Alfonso de Castro também se conservará na Companhia, pois dá tão bom odor de si." Carta de Inácio de Loyola para Nicolao Lancellotte. Roma, 27. 01 1552,. In Documenta Indica II. Op. cit., p. 312.

206 "Em Maluquo se alevantou um com a obediência, fazendo um escrito falso pelo qual se fez obediência." In Documeta Indica V (1561-63). Op. cit., p. 201.

${ }^{207}$ Ver Afonso de Castro ver O’Neill, Charles E. S. I., e Domínguez, Joaquín Ma S. I. Op. cit., vol. I, pp. 706707. 
por ser saber ser cristão novo”. Ou seja, era de se esperar, conforme o padre jesuíta, que onde houvesse cristão novo as possibilidades de haver "escândalo" aumentavam. Portanto, os escândalos por eles causados não seriam surpresas. A observação do jesuíta Antônio de Heredia expressa uma certa má vontade, ou melhor, alguma dificuldade em aceitar os cristãos novos como sendo um dos seus iguais. Em outras palavras, o comentário do inaciano pode ter revelado sua própria discriminação em relação aos descendentes dos judeus.

Antônio Vaz, além de não ter conseguido o cargo que pleiteava, não permaneceu nas Molucas. Não se sabe ao certo se foi mandado embora por Afonso de Castro ou se saiu voluntariamente. Os padres Antônio de Quadros e Francisco Cabral disseram que ele foi despedido. Enquanto que o padre Francisco Rodrigues não sabia dizer se foi afastado ou se saiu voluntariamente.

O que se sabe ao certo é que cerca de dois anos após os desentendimentos (1558), Antônio Vaz retornou à Companhia de Jesus. Os jesuítas cristãos velhos de Goa o receberam.

Afonso de Castro foi raptado e assassinado pelos nativos de Ternate em dezembro de 1557. É o que nos informa o "Diccionario Histórico de la Compañia de Jesús Biográfico-Temático”208.

Esta disputa, caso de fato ela tenha ocorrido, demonstrou que os dois jesuítas cristãos novos ignoraram o passado comum que possuíam graças aos seus interesses pessoais. Portanto, ser descendente de judeu não foi motivo suficiente para ambos chegarem a um acordo pacífico. A incapacidade de entendimento de ambos deu margem a comentários negativos. Em função dos seus próprios interesses, Afonso de Castro e Antônio Vaz comprometeram ainda mais a reputação dos cristãos novos na Companhia de Jesus ${ }^{209}$.

\footnotetext{
${ }^{208}$ O’Neill, Charles E. S. I., e Domínguez, Joaquín Ma S. I. Op. cit., vol. I, p. 707.

${ }^{209}$ Entre 1546 e 1562, além de Henrique Henriques, Afonso de Castro e Antônio Vaz, encontravam-se nas missões orientais os seguintes jesuítas cristãos novos: Manuel Alvarez, Antônio Dias, Jerônimo Fernandes, Gabriel d’Oliver, Luís d’Almeida, Bartolomeu dos Santos, Antônio Fernandes, Fernão de Narbona e Antônio Bello. Ver Documenta Indica IV. Op. cit., pp. 448-463 e Documenta Indica VII. Edidit Ioseph Wicki S. I. Romae, Apud "Monumenta Historica Soc. Iesu, 1962, pp. 73-81.
} 
Quando Henrique Henriques foi escolhido para ser o Superior Regional da Costa da Pescaria, ficou manifesto que desde aquele momento os portugueses no Oriente já discriminavam os cristãos novos. Em 1556 Henrique Henriques, agora na condição de Superior Regional, confirmou a existência do anti-semitismo.

Henrique Henriques não deixou claro quem eram os portugueses contrários à sua escolha para o cargo de Superior Regional. Ele se referiu apenas aos portugueses. Mas em 1556, em suas queixas ao Geral Inácio de Loyola, ele se reportou às críticas pessoais sofridas. Se no primeiro caso não houve nenhuma referência aos seus colegas jesuítas, no segundo ocorreu alusão a eles.

De 1559 em diante seus críticos se manifestaram publicamente e o padre Antônio de Heredia registrou o protesto contra a ocupação de cargos de comando na Companhia por parte dos cristãos novos, citando o caso de Henrique Henriques como exemplo, além de ter expressado o seu próprio preconceito em relação aos cristãos novos.

O padre Antônio de Heredia não esclareceu quem era contra a presença de cristãos novos nas funções de comando da Companhia de Jesus. Mas é plausível supor que ele se referia, também, aos próprios jesuítas.

Por sua vez, o jesuíta Melchior Carneiro não deixou dúvidas a respeito de quem discriminava os cristãos novos no Oriente, ao "constatar" que o povo tinha pouca estima por Henrique Henriques porque ele era cristão novo.

Se o padre Melchior Carneiro estava realmente falando a verdade, não é menos verdade que Antônio de Heredia carregava consigo o mesmo preconceito que, segundo Melchior Carneiro, o povo tinha contra os cristãos novos.

As críticas e as discriminações que Henrique Henriques recebeu se devem a dois fatores complementares e indissociáveis: Era um cristão novo, ou seja, carregava consigo o estigma criado ao longo de grande parte da história do povo judeu, principalmente durante a segunda diáspora. Tinha uma razoável formação e era um missionário incansável. Ao invés de lhes ser favoráveis, suas qualidades 
pessoais provocaram mal-estar em alguns cristãos velhos jesuítas. Assim agiam os anti-semitas.

Foi em torno do cristão novo Henrique Henriques que alguns jesuítas no Oriente iniciaram uma série de atitudes hostis contra os conversos. E foi a partir de 1559 que essas atitudes foram assumidas publicamente e deixaram de ser manifestações isoladas e esporádicas.

Em 1557 foi encontrado um escrito “blasfemo” em Cochim, cuja autoria foi atribuída aos cristãos novos. Dois jesuítas se destacaram na perseguição dos supostos culpados, Gonçalo da Silveira e Belchior Carneiro. Vários foram os conversos presos. Os jesuítas envolvidos no caso reclamaram a necessidade da presença do Tribunal do Santo Ofício nas missões orientais. Por causa, principalmente, dos apelos dos inacianos, a Inquisição chegou em Goa em 1560.

Em 1560 as consciências já estavam suficientemente preparados para acender as fogueiras do Santo Ofício da Inquisição. Os poderes econômico, político, militar e religioso estavam com suas bases devidamente consolidadas. No que tange à Companhia de Jesus, tanto o caso de Henrique Henriques quanto o do escrito “blasfemo” de Cochim, comprovaram que o momento da Inquisição em Goa havia chegado.

A intolerância em ralação aos cristãos novos nas missões orientais assumiu uma nova feição após a instalação do Tribunal do Santo Ofício. Criminalizou-se o suposto cripto-judaismo. Praticamente todos os conversos tornaram-se suspeitos dessa heresia. Como veremos logo a seguir, a Companhia de Jesus desempenhou um papel de destaque na intolerância inquisitorial de Goa ${ }^{210}$.

Em dezembro de 1573 a problemática dos cristãos novos na Companhia de Jesus ressurgiu na documentação jesuítica. O padre Alexandre Valignano ${ }^{211}$

\footnotetext{
${ }^{210}$ Voltaremos a essa questão no próximo capítulo, que tratará da participação da Companhia de Jesus no Tribunal do Santo Ofício.

211 Alexandre Valignano nasceu em Chieti (Itália) em Fevereiro de 1539. Foi admitido por Francisco de Borgia - futuro Vigário Geral da Companhia, em Maio de 1566. Embarcou para o Oriente em Março de 1574 com mais quarenta e dois missionários. Foi visitador no Oriente em duas oportunidades, 1574-83 e 1587-96 e provincial da Província de Goa entre 1583-87. Faleceu nas missões orientais em janeiro de 1606. Ver
} 
escreveu para o Geral Everardo Mercuriano a respeito do envio de jesuítas para o Oriente. Sua expectativa era a de que entre os selecionados não houvesse nenhum cristão novo ${ }^{212}$.

Em doze de janeiro de 1574 Alexandre Valignano tornou a escrever ao Geral tratando do mesmo assunto, ou seja, do envio de cristãos novos jesuítas para o Oriente. Nesta missiva ele afirmou que seria desastroso se fossem enviados castelhanos, e mais desastroso ainda seria caso os enviados, além de castelhanos, fossem cristãos novos. Isso, dizia ele, devia ser evitado mais do que tudo ${ }^{213}$.

Ao longo da correspondência ele justificou ao Geral sua preocupação com a questão dos cristãos novos na Companhia de Jesus. Alexandre Valignano notou que esse era o tema predominante entre os superiores e padres cristãos velhos não somente em Almeirim, mas em todo Portugal. Segundo ele, os jesuítas estavam divididos em relação à problemática dos conversos e previu que este problema poderia tornar-se a causa da ruína da Companhia de Jesus.

Ele sugeriu três medidas para resolver o impasse: proibir o recebimento dos conversos, ou recebê-los apenas com licença especial, ou extinguir a distinção entre cristão novo e cristão velho na Companhia de Jesus. Pessoalmente ele foi favorável ao fim da distinção. Isso fica claro quando disse que "era necessário que se extinguisse a maledicência e a perseguição contra eles"214.

Transcorridos dezesseis dias, ou seja, em 28. 01. 1574 Alexandre Valignano escreveu outra carta para Everardo Mercuriano. Sua opinião sobre o que fazer com os cristãos novos havia mudado. A Província de Portugal e as demais províncias da

Rodrigues, Francisco. A Companhia de Jesus em Portugal e nas Missões. Esboço Histórico - Superiores Colégios - 1540-1934. Segunda Edição. Porto, Edições do Apostolado da Imprensa, 1935, pp. 26 e 33. Ver ainda Sommervogel, Carlos. Bibliotheque de la Compagnie de Jesus. Bruxelles, Vol. 8, 1898, p. 403.

212 “... outros acerca dos quais se entendesse como certo que eram conversos, embora eu espere que destes não haja nenhum.” Documenta Indica X. Edidit Ioseph Wicki S. I. Romae, Apud “Monumenta Historica Soc. Iesu,, 1966, p. 46. Sou profundamente grato à gentileza do professor da Faculdade de Letras da Universidade de Lisboa, o dr. Arnaldo Espírito Santo, que traduziu este e outros textos do latim para o português.

213 "Seria desastroso se enviasse castelhano e sobretudo se tivesse alguma mancha ou raça de confesso (converso), o que deve ser evitado mais do que tudo (tradução do professor Arnaldo Espírito Santo). In Documenta Indica IX. Edidit Ioseph Wicki S. I. Romae, Apud “Monumenta Historica Soc. Iesu,1984, p. 89.

${ }^{214}$ O diagnóstico feito por Alexandre Valignano sobre os cristãos novos na Companhia de Jesus e as soluções por ele propostas encontram-se na mesma carta de 12. 01. 1574. In Documenta Indica IX. Op. cit., pp. 92-93. 
Companhia de Jesus, dizia ele, não deveriam receber os conversos, exceto os de raça $^{215}$.

No dia oito de fevereiro Alexandre Valignano, em mais uma carta enviada para o Geral, afirmou que o rei e o cardeal não queriam que fossem enviados conversos para as missões no Oriente ${ }^{216}$. É possível que Alexandre Valignano estivesse falando a verdade. Principalmente no caso do Cardeal Henrique, que naquele momento era o inquisidor geral de Portugal e muito próximo à Companhia. Seu confessor era o jesuíta Leão Henriques ${ }^{217}$.

Em 1559 o Cardeal Henrique fundou a Universidade de Évora, a qual foi entregue aos jesuítas. Quanto ao monarca D. Sebastião, o jesuíta Luís Gonçalves da Câmara foi seu confessor e mestre entre 1559 e 1574. A rainha D. Leonor o indicou e o Cardeal anuiu a indicação ${ }^{218}$. Luís Gonçalves da Câmara foi substituído pelo também jesuíta Maurício (ou Gaspar) Serpe, que permaneceu na função de confessor até a morte de ambos, ocorrida em Alcácer-Quibir (1578) ${ }^{219}$.

É provável que, além de outros fatores, ao saber da posição do rei e do cardeal concernente aos cristãos novos, Alexandre Valignano tenha mudado seu parecer a respeito do envio de cristãos novos às missões orientais.

Cerca de um mês antes do embarque de Alexandre Valignano ocorreu um fato que nos dá uma idéia aproximada do “status” social dos cristãos novos em Portugal. Ele discutiu com um grupo de jesuítas sobre as condições da viagem para o Oriente. Inclusive, neste grupo se encontrava o Provincial de Portugal, o padre Jorge Serrão. Irritado, Alexandre Valignano se dirigiu para os inacianos presentes

\footnotetext{
215 “Julgar-se-á no Senhor que não se admitam daque em diante, ou que não se admitam nesta e em qualquer outra Província, ou que não se receba os ditos confessos, mas não se excluam aqueles que chamamos de raça." Cristão novo de "raça" eram os descendentes de judeus, mas cujos pais não foram judeus, ou seja, sem "linha reta”. In Documenta Indica IX. Idem, p. 118.

216 "A maioria destes eram confessos (conversos) dos quais o rei de modo nenhum queria que fossem e muito menos o cardeal.” In Documenta Indica IX. Idem, p. 156.

${ }^{217}$ Leão Henriques foi o Vice-Provincial de Portugal em 1565 e Provincial entre 1566-70. Ele participou da Congregação Geral que elegeu Everardo Mercuriano, ocorrida em 1573.

${ }^{218}$ Sobre Luís Gonçalves da Câmara, ver O’Neill, Charles E. S. I., e Domínguez, Joaquín Ma S. I. Op. cit., Vol. I, pp. $608-609$.

Sobre a presença dos jesuítas na corte portuguesa ver Marques, João Francisco. Op. cit., especialmente as páginas 246-48.
} 
dizendo que eles não o confundissem com um cristão novo ${ }^{220}$. Esta fala deixa evidente que havia entre os jesuítas portugueses, de forma relativamente generalizada, desrespeito com os cristãos novos. Alexandre Valignano, ao pronunciar esta frase, também nos deu a entender que o cristão novo não tinha nenhum prestígio na sociedade portuguesa.

O padre Francisco de Porres, procurador da Companhia de Jesus na corte espanhola, era do mesmo parecer de Alexandre Valignano a respeito do envio de cristãos novos espanhóis para as missões orientais da Companhia de Jesus em terras dominadas pelos portugueses. Ele era contrário ao envio porque os cristãos novos espanhóis não seriam bem recebidos pelos portugueses (seculares e regulares). Para estes ser castelhano era informação suficiente para concluir que se tratava de um descendente de judeu. Portanto, caso fossem enviados, dizia o padre Francisco de Porres, viveriam durante toda vida no desgosto e na amargura ${ }^{221}$.

Quando estava em Moçambique, a caminho do Oriente, Alexandre Valignano, mais uma vez, escreveu para Everardo Mercuriano alertando que não deviam ser enviados cristãos novos espanhóis. Porque, dizia o padre, mesmo sendo bons e santos, são detestados pelos portugueses. Em função desse ódio, seriam todos inúteis e comprometeriam a reputação da Companhia de Jesus ${ }^{222}$.

Está claro que havia uma fortíssima intolerância em relação aos cristãos novos no Oriente. Também está evidente que era maior a resistência aos cristãos novos espanhóis por parte dos portugueses. O argumento utilizado pelos lusitanos, conforme o padre Francisco de Porres, era o de que todo castelhano tinha ascendência judaica. Porém, isso não esclarece toda a questão. O próprio Alexandre

\footnotetext{
${ }^{219}$ A respeito de Maurício Serpe ver Charles E. S. I., e Domínguez, Joaquín Ma S. I. Op. cit., Vol. IV, p. 3559.

220 “... entrou com tanta cólera e disse tais palavras que nos espantamos, até dizer que não pensássemos que falávamos com cristãos novos.” Excerto da Carta do p. Jorge Serrão enviada para o Geral Everardo Mercuriano. Lisboa, 11. 02. 1574. Documenta Indica IX. Op. cit., p. 180.

${ }^{221}$ Carta do padre Francisco de Porres para o Vigário Geral Everardo Mercuriano. In Documenta Indica IX. Op. cit.,p. 647.

222 "E acima de tudo se há de advertir que entre aqueles que venham da Província da Espanha não haja nenhum que tenha raça de confesso porque são tão detestado pelos portugueses que ainda que sejam não só bons mas também santos, são inúteis e rapidamente conhecidos com pouca reputação para nós." Excerto da Carta escrita em 07. 08. 1574. Idem, p. 412.
} 
Valignano já havia aconselhado que a Companhia evitasse o envio de jesuítas espanhóis para as missões portuguesas no Oriente. Ele não esclareceu o motivo dessa discriminação.

Porém, o embaixador de Portugal na Espanha, D. Eduardo de Castelo Branco, elucidou parte da questão. "É sabido que o Embaixador de Portugal tem dito que não convém enviar Padres castelhanos para a Índia de Portugal, e dá para isso algumas razões segundo é entendido, uma porque os castelhanos por força haverão de favorecer aos castelhanos"223. Ou seja, havia rivalidade entre os jesuítas espanhóis e portugueses. A preferência devia ser dada aos jesuítas portugueses quando as missões se encontravam em terras conquistadas pelos lusitanos.

Tornava-se cada vez mais difícil o envio de cristãos novos para o Oriente. Em Portugal eles eram uma das questões mais discutidas e delicadas. Era do conhecimento geral a intolerância que sofriam nos domínios portugueses do Oriente. Autoridades como o rei e o cardeal, conforme assegurou Alexandre Valignano, não queriam que os jesuítas os enviassem para as possessões orientais. A Inquisição em Goa prendia, confiscava seus bens e os condenava - inclusive à morte, desde $1560^{224}$.

Neste contexto, foi realizada uma consulta na Província de Goa entre os dias seis e dezoito de dezembro de 1575. A coordenação dos doze dias de trabalho ficou a cargo do então visitador Alexandre Valignano. Participaram da consulta os padres mais antigos e os superiores das missões, dezoito jesuítas no total. Entre eles encontravam-se o padre Provincial Rui Vicente e os cristãos novos Henrique Henriques e Gomes $\operatorname{Vaz}^{225}$.

\footnotetext{
${ }^{223}$ Extrato da carta do padre Francisco de Porres - procurador da Companhia de Jesus na corte de Espanha, enviada para o Vigário Geral Everardo Mercuriano. Madrid, 01. 06. 1575. In Documenta Indica IX. Idem, p. 645.

${ }^{224}$ O primeiro auto-de-fé público em Goa ocorreu em 1562. A convite do Arcebispo e Inquisidor Geral D. Gaspar de Leão Pereira, o auto teve como pregador o Provincial da Província de Goa Antônio de Quadros. Ver carta do padre Baltasar da Costa de 04. 12. 1562. In Documenta Indica V. Op. cit., pp. 598-99. Essa prática tornou-se corriqueira entre os jesuítas. Voltaremos a esse tema posteriormente.

${ }^{225}$ Na relação dos nomes encontra-se um tal "padre Vaz", que pode ser o padre Antônio Vaz, o mesmo que se desentendeu com o também cristão novo Afonso de Castro.
} 
A pergunta de número trinta e oito queria saber quais seriam as pessoas que a Companhia deveria receber "naquelas partes e de que idade.” Quanto aos cristãos novos, todos responderam que não deviam ser recebidos, sem nenhuma exceção, até mesmo os mais virtuosos. Dois foram os motivos alegados: os conversos tinham pouco crédito e seus parentes eram sentenciados pelo Santo Ofício da Inquisição, o que causava escândalo e infâmia na Companhia ${ }^{226}$.

Com a aprovação da exclusão dos cristãos novos ocorrida na consulta de 1575, a Província de Goa formalizava o seu próprio anti-semitismo. A resposta em uníssono à pergunta trinta e oito (“que pessoas se hão de receber na Companhia?”) significou a desobediência às Constituições. Estava quebrado o voto de obediência. Os interesses e "necessidades” locais sobrepuseram-se à unidade de pensamento e ação pregada pelos padres fundadores da Ordem dos inacianos.

Por outro lado, as próprias Constituições, aprovadas em 1558, já haviam aberto um precedente. Ao perguntar se o candidato tinha antepassados judeus, favoreceu a permanência e o crescimento do sentimento anti-semita na Companhia de Jesus. Talvez por esse e outros motivos, o comando da Ordem, sediado em Roma, não esboçou nenhuma reação à falta de disciplina nas missões das Índias Orientais. Enfim, todos silenciaram-se ${ }^{227}$.

A questão do envio de jesuítas espanhóis para as missões da Companhia de Jesus nos domínios portugueses no Oriente continuava insolúvel. O padre Lourenço Mexia, ironicamente ou não, acreditava que isso era artifício e manha do demônio, principalmente quando os castelhanos a serem enviados fossem "limpos de raça de cristãos novos”. O plano do demônio seria, dizia Lourenço Mexia, deixar as missões orientais sem padres, ou que os que lá permanecessem fossem inúteis e mesmo assim poucos. Já existiam restrições ao ingresso dos mestiços (que ele achava justas)

\footnotetext{
226 "E pareceu que os que têm alguma raça de cristãos novos não devem ser recebidos, porque, mesmo que fossem muito virtuosos, lhes têm muito pouco crédito e muitas vezes acontece que seus parentes são sentenciados pelo Santo Ofício da Inquisição, o que causa grande escândalo e infâmia na Companhia.” Documenta Indica X. Op. cit., p. 284.

${ }^{227}$ Quer dizer, não foi encontrado nenhum documento protestando contra a intolerância dos jesuítas que participaram da consulta de 1575 realizada na Ilha de Chorão.
} 
e os que foram recebidos possuíam sérias limitações. Na Itália não havia padres suficientes para suprir as necessidades de toda a Companhia, enquanto que em Portugal estava ocorrendo um intenso processo de mescla entre cristãos novos e cristãos velhos. Esse foi o quadro traçado por Lourenço Mexia ${ }^{228}$.

Não deixou de ser uma defesa brilhante da política de unificação entre os jesuítas espanhóis e portugueses nas missões orientais.

Ele também não deixou de expressar o seu anti-semitismo quando defendeu os jesuítas espanhóis.

O panorama descrito pelo padre Lourenço Mexia em relação às dificuldades que a Companhia de Jesus vinha passando para suprir a necessidade de missionários foi verídico. O problema realmente estava grave. Vale lembrar que já haviam transcorrido dois anos que a consulta ocorrida em Chorão decidiu que as missões orientais não deveriam receber cristãos novos.

Para solucionar ou amenizar a situação o mais rápido possível, o Arcebispo de Lisboa, D. Henrique, concedeu licença para a Companhia de Jesus antecipar as ordenações dos padres, antes mesmo da chegada do Breve do Papa Gregório XIII autorizando as referidas ordenações ${ }^{229}$.

Apesar da ausência de uma posição formal da Província de Portugal em relação à exclusão dos cristãos novos aprovada na consulta de 1575, houve resposta. A Província lusitana continuou enviando missionários conversos para o Oriente ${ }^{230}$. Goa protestou veementemente. O litígio estava instalado entre as duas Províncias.

\footnotetext{
${ }^{228}$ Carta enviada para o Vigário Geral Everardo Mercuriano em 22. 11. 1577. In Documenta Indica X. Op. cit., p. 1014.

229 "Porque o P. ${ }^{e}$ Pero da Fonseca me escreveu que tinha havido já o Breve de Sua Santidade para ordenar extra tempora os que daqui desta Província vão para a Índia, sobre esta sua fé o Arcebispo desta cidade de Lisboa concedeu licença para se ordenarem os que quiséssemos sofre esta fé do o P. ${ }^{e}$ Pero da Fonseca." Extrato da carta do padre Martinho da Silva enviada para o Vigário Geral Everardo Mercuriano. Lisboa, 18. 03. 1578. In Documenta Indica XI. Edidit Ioseph Wicki S. I. Romae, Apud "Monumenta Historica Soc. Iesu, 1970, p. 156. O Breve somente ficou pronto em dezembro de 1577.

${ }^{230}$ O cristão novo Duarte de Sande foi enviado para as "Índias" em vinte e quatro de Março de 1578, na condição de superior do grupo de missionários que embarcou com ele. Teve uma carreira de destaque. Foi reitor em Bassain, eleito superior das missões na China, superior da residência de Macau e reitor do colégio. Ver Charles E. S. I., e Domínguez, Joaquín Mª S. I. Op. cit., vol. IV, p. 3495.
} 
A reação “goesa” ficou a cargo do Provincial Rui Vicente ${ }^{231}$. Em carta enviada ao Vigário Geral Everardo Mercuriano ele culpou os superiores de Portugal por terem recebido os cristãos novos. Para se livrarem do problema que causaram, dizia Rui Vicente, os enviavam para o Oriente. Já que não foi a Província de Goa que os recebeu, continua o Provincial, não seria ela quem faria a "penitência” de aceitá-los. Para Rui Vicente seria muito mais difícil recebê-los nas Índias orientais porque os conversos eram mais discriminados do que em Portugal, além de serem mais conhecidos.

O Provincial Rui Vicente acreditava que esse não era o desejo do Vigário Geral (Everardo Mercuriano), o de comprometer as missões orientais com uma “carga pesadíssima e sem proveito”, que ao invés de engrandecer a Companhia lhe “causaria descrédito”. Enfim, se de fato, os superiores de Portugal estavam enviando os cristãos novos apenas para se livrar deles, isso seria algo desprezível, protestou Rui Vicente.

Ele não deixou dúvidas de que a solução do problema cabia ao Vigário Geral. Mas nem por isso se omitiu a respeito do recebimento de cristãos novos. Não iria receber nenhum deles, por mais qualificados que fossem. Pois caso fossem recebidos, argumentava, as missões no Oriente poderiam fracassar ${ }^{232}$.

Foi uma dura resposta dada à tolerância da Província portuguesa com os cristãos novos. Um duríssimo golpe recebido pelos conversos.

\footnotetext{
${ }^{231}$ Provincial entre 1574-83.

232 “Também tenho entendido e ainda experimentado que os superiores de Portugal, para livrar-se, nos carregam com cristãos novos. Já que eles tiveram a culpa em receber tais sujeitos, não é razão que nós levemos a penitência, principalmente que aqui são mais mas recebidos e mais conhecidos, e creio que isso não corresponde à vontade de V. P. que tanto tem acreditada esta missão, e se isto acontece como me dizem que acontece, fica de muito baixos quilates. V. P. usará o remédio que lhe parecer conveniente, mas creia $V$. $P$. que é carga pesadíssima e sem proveito e ainda com descrédito da Companhia, ao menos eu não me atreveria em receber nenhum deles por muito qualificações que ele tivesse, porque com isto desvanecem tudo.” Carta escrita em Goa no dia 01. 12. 1578. In Documenta Indica XI. Op. cit., p. 445.
} 
Esta será a linha geral adotada pelas missões orientais conduzidas pelos jesuítas portugueses ${ }^{233}$. Protestar, reagir contra o envio de cristãos novos efetuado pela Província de Portugal.

O Aitão ${ }^{234}$ queria saber quem eram aqueles homens da povoação portuguesa sob o domínio chinês, que pediam secretamente aos governadores casa e lugar para suas cerimônias. O jesuíta Fernando de Meneses sabia que tratava-se de cristãos novos e não ficou surpreso. Pois, dizia ele, em Portugal e na Índia os conversos estavam sendo queimados exatamente pelo mesmo motivo, ou seja, por judaizarem. Comumente os cristãos novos não eram bons cristãos - quer dizer, judaizavam, concluiu o padre Fernando Meneses ${ }^{235}$.

Entretanto ele não era contrário ao recebimento dos cristãos novos em geral. Fez restrições àqueles cujos pais, mães ou irmãos tivessem sido queimados publicamente $^{236}$. Ou seja, nos casos mais graves da "heresia judaizante” Fernando de Meneses era favorável à exclusão.

O jesuíta Fernando de Meneses comunicou ao geral a chegada do cristão novo Jorge Fernandes, cujo avô paterno (Jorge Fernandez Lagos) "jurou de leve suspeito na fé, ${ }^{237}$, escreveu também que os conversos eram muito amigos uns dos outros, inclusive os religiosos, o que para ele era algo admirável ${ }^{238}$. Como exemplo desta amizade, relatou o caso do cristão novo Duarte de Sande, que teria dito a Pero Gomez ter sido enviado como Provincial ${ }^{239}$. Uma amizade capaz de “mentir” para

\footnotetext{
${ }^{233}$ O problema do envio de cristãos novos de Portugal para o Oriente permaneceu, na documentação consultada, até 1587.

${ }^{234}$ Título do Almirante chinês. O seu tribunal tinha jurisdição sobre a gente do Mar e sobre os estrangeiros.

235 "Mas eu não me admiro disto porque há ali mais de 300 cristãos novos que comumente não são bons cristão, mas cada dia os queimam por heresia em Portugal e na Índia.” Excerto da carta enviada para o Vigário Geral Everardo Mercuriano. Goa, 15. 11. 1579. In Documenta Indica XI. Idem, p. 731.

236 "E certo eu receio muito que se nós recebemos desta gente alguns que ao menos saiam seus pais ou mães ou irmãos queimados publicamente.” Idem, ibidem.

${ }^{237}$ Documenta Indica XI. Op. cit., p. 731.

238 "Eles são tão amigos unos dos outros, ainda religiosos, que é coisa admirável.” Idem, ibidem.

239 "Começou a divulgar que vinha por Provincial." Idem, ibidem. Mencionamos anteriormente que Duarte de Sande foi o superior do grupo enviado para o Oriente.
} 
ajudar os amigos ${ }^{240}$. Talvez este tenha sido um dos motivos da admiração do cristão velho Fernando Meneses.

Apesar de Duarte de Sande ter se apresentado, segundo Fernando Meneses, como Provincial, o próprio Fernando Meneses constatou a amizade existente entre o verdadeiro Provincial, Rui Vicente, e Duarte de Sande que, além de amigos, eram parentes por linha paterna. Entretanto, havia o rumor de que o Provincial fosse cristão novo. Fernando Meneses não confirmou nem desmentiu a suspeita. Por outro lado, informou ao Geral que os amigos de Rui Vicente não confessavam e que os demais confessavam irregularmente ${ }^{241}$.

Fernando Meneses deu a entender que, mesmo que Rui Vicente não fosse cristão novo, não era um bom Provincial. Pois negligenciava no sacramento da confissão. E o que era mais grave: seus amigos não confessavam.

Logo a seguir Fernando Meneses voltou a falar a respeito de Duarte de Sande. Teceu uma série de críticas. Ele era feio, quase anão, não foi um bom aluno, pregava mau e era temperamental.

Além de Duarte de Sande, Rui Vicente tinha outro amigo. Tratava-se de Lourenço Pinheiro, também suspeito de ser cristão novo. Também não possuía boa reputação com Fernando Meneses. Via nele um “amigo da honra e vaidade.,242

Mesmo, segundo Fernando de Meneses, tendo sido um mau aluno e um pregador ruim, Duarte de Sande teve uma carreira de sucesso na Companhia de Jesus.

A partir dos comentários a respeito dos cristãos novos, nota-se facilmente que o jesuíta Fernando de Meneses não era simpático aos conversos. Seu recado foi dado: eram inconvenientes para a Companhia. Fica assim comprovado que o padre Fernando de Meneses era anti-semita.

\footnotetext{
${ }^{240}$ Foram falar com Duarte de Sande “dizendo-lhe que não dissesse aquilo, dali somente começavam alguns a inferir o que era, que certo me dava paixão por ser Pero Gomez homem virtuoso.” Idem, ibidem.

241 "Não vejo ordem na igreja em confessar mas muita desordem, já os privados nunca confessam." Documenta Indica XI. Idem, pp. 735-36.

242 “É notavelmente amigo da honra e vaidade”. Documenta Indica XI. Op. cit. p. 736.
} 
O padre Pedro Dias ouviu dizer que o Vigário Geral Everardo Mercuriano havia proibido os cristãos novos de exercerem cargos de comando. Entretanto, o que ele via era exatamente o contrário. Não respeitavam os superiores, e estes somente tomavam alguma decisão após consultá-los. Os conversos diziam que quem possuía o poder de mando era " $N$. $N$., (deve ser uma referência a Jesus Cristo) cujos parentes sunt levitae e scribae (i.e. cristão dito novo)”, e não o Provincial, assegurou Pedro Dias $^{243}$.

É provável que Pedro Dias tenha constatado o forte poder de influência que os cristãos novos exerciam na política missionária adotada pelos provinciais e o alto grau de confiança que os provinciais depositavam nos conversos, em função de sua grande capacidade missionária.

Este estado de coisas, ou seja, a presença de destaque dos cristãos novos nas missões orientais causou mau estar no jesuíta cristão velho. Pedro Dias não fez nenhuma referência ao anti-semitismo dos portugueses, consequentemente não disse que a reputação da Companhia estaria comprometida devido à influência dos cristãos novos nos destinos das missões. Sua questão estava circunscrita aos interesses pessoais, à ocupação de cargos de comando e ao poder de influência nas políticas missionárias.

Quando estava no Japão como visitador (agosto de 1580), Alexandre Valignano redigiu um texto sobre as pessoas necessárias para aquela Província. Todos os cristãos novos vindos de Portugal deviam ser excluídos, por mais talentosos, qualificados e santos que pudessem ser e independentemente do grau de "sangue judeu” que carregassem.

Mesmo que a Província portuguesa os enviasse, não seriam recebidos. É uma nova postura, independente de Portugal, autônoma. Já não pedia mais que os superiores de Portugal não enviassem cristãos novos; a partir daquela data simplesmente ninguém receberia os cristãos novos que fossem enviados. É uma

\footnotetext{
${ }^{243}$ Ver Carta enviada para o Prepósito Geral Everardo Mercuriano. Cochim, 29. 06. 1580. In Documenta Indica XI. Idem, p. 26.
} 
postura diferente da que assumiu o Provincial Rui Vicente em dezembro de 1578. Naquela oportunidade ele dizia para o Vigário Geral Everardo Mercuriano que não se atreveria em receber cristãos novos. Foi uma decisão pessoal. Agora tratava-se de uma resolução provincial.

Alexandre Valignano justificou sua decisão argumentando que os portugueses e os forasteiros consideravam os cristãos novos, mesmo os mais santos, falsos cristãos, gente fingida, infame e judeus. Devido a esse descrédito, dizia Alexandre Valignano, viviam sempre inquietos. Finalmente, caso a Companhia de Jesus os recebesse perderia muito da sua reputação e crédito ${ }^{244}$.

Portanto, Alexandre Valignano entendeu que, para preservar a reputação da Companhia, era necessário excluir os cristãos novos da missão no Japão.

Em Outubro de 1580 o Colégio de Goa necessitava, com certa urgência, de um vice-reitor. Porém, estava difícil encontrar alguém capacitado para ocupar o cargo. Finalmente foi indicado o padre Lourenço Pinheiro. Entretanto, ele não foi imediatamente aceito porque havia o receio de ser mau recebido e causar protesto devido à “sua natural condição"245. Apesar do impasse, o Provincial Rui Vicente estava disposto a confirmar a indicação ${ }^{246}$.

O próprio Provincial Rui Vicente escreveu para o Geral Everardo Mercuriano em três de janeiro de 1581 confirmando a indicação de Lourenço Pinheiro para o cargo de vice-reitor do Colégio de Goa. Alias, além de escolhido para este função, Lourenço Pinheiro ficou encarregado, graças às suas qualidades, de ler os casos de consciência, função inédita na Índia ${ }^{247}$.

\footnotetext{
${ }^{244}$ Ver Documenta Indica XIII (1583-85). Edidit Ioseph Wicki S. I. Romae, Apud "Monumenta Historica Soc. Iesu", 1975, pp. 251-255, que tratam dos "Dos sujeitos necessários para esta Província e suas qualidades", especialmente a página 254 onde se lê: "E sobretudo se há de advertir que não tenham nenhuma raça de cristãos novos, porque, mesmo que estes fossem santos, não aproveitam nem têm nenhum crédito com os portugueses, e vivem sempre inquietos, porque são vistos pelos forasteiros e pelos nossos como gente infame e fingida." e as páginas 258-262 referentes aos "sujeitos que se hão de receber e excluir nesta Província".

${ }^{245}$ Já foi mencionado anteriormente - nota 264 - que Lourenço Pinheiro era suspeito de ser cristão novo.

${ }^{246}$ A esse respeito ver carta do padre Nuno Rodrigues (reitor do Colégio de Goa) para o Vigário Geral Everardo Mercuriano. Goa, 24. 10. 1580. In Documenta Indica XII. Op. cit., pp. 129-30.

247 “... e assim ficou por vice-reitor o Padre Lourenço Pinheiro, que também ler casos de consciência, o qual pareceu mais a propósito para o fim que se pretendia. Embora eu tive dificuldade em ser isto coisa nova na
} 
A decisão ficou a cargo de Rui Vicente. Ele não apenas aceitou Lourenço Pinheiro no cargo de vice-reitor do Colégio de Goa, como também lhe atribuiu uma nova atividade nas missões orientais: a de leitor dos casos de consciência. Embora Rui Vicente tenha reagido, de modo contundente, contra o envio de cristãos novos para as Índias orientais ${ }^{248}$, ele não teve como evitar a dupla promoção de um cristão novo em sua Província. A necessidade do preenchimento dessas funções e a melhor capacitação de Lourenço Pinheiro foram os fatores determinantes nas escolhas do Provincial. O mérito dos cristãos novos ainda tinha o poder de superar a discriminação contra eles.

Lourenço Pinheiro permaneceu no cargo de vice-reitor do Colégio de Goa por volta de dois anos. Foi demitido pelo Provincial Rui Vicente, o mesmo que o havia promovido. O padre Nuno Rodrigues acreditava que o motivo da exoneração fosse "a natural condição do Padre Lourenço Pinheiro que tem de dominar mais do que de servir" 249 .

Porém, o padre Nuno Rodrigues esqueceu-se de considerar que houve entre alguns jesuítas “receio” e “temor” (palavras do próprio Nuno Rodrigues) à indicação de Lourenço Pinheiro por causa da sua "condição natural”. Ou seja, por ser cristão novo ${ }^{250}$.

Transcorrido aproximadamente um ano, o padre Fernando de Meneses tornou a escrever para o Prepósito Geral Everardo Mercuriano tratando dos cristãos novos (dezembro de 1580). Em um estilo semelhante ao da carta de Rui Vicente, escrita em dezembro de 1578, disse que "Portugal não fazia senão descartar-se de cristãos novos”, e que ao chegarem logo eram reconhecidos por todos como cristãos novos.

\footnotetext{
Índia, mas a necessidade pareceu urgente e que por isso V. P. o consideraria acertado, como tem mostrado a experiência.” Extrato da carta do padre Provincial Rui Vicente enviada para o Prepósito Geral Everardo Mercuriano. Cochim, 03. 01. 1581. Documenta Indica XII. Idem, p. 198.

${ }^{248}$ Ver a esse propósito as páginas 76 e 77.

${ }^{249}$ Carta enviada para o Geral Everardo Mercuriano. Goa, 11. 11. 1582. In Documenta Indica XII. Idem. p. 639.

${ }^{250}$ Ele não foi o primeiro jesuíta cristão novos a ser destituido do cargo que ocupava. Em 1576 o jesuíta cristão novo Henrique Henriques já havia sido demitido do cargo de Superior Regional. Suas atividades ficaram restritas à escrita e publicação de livros cristãos em língua tamil. Ver Charles E. S. I., e Domínguez, Joaquín Mª S. I. Op. cit., vol. I, p. 178.
} 
Praticamente repetindo o que escreveu o padre Pedro Dias disse, ou melhor, denunciou ao Geral, que os cristãos novos além de governarem eram estimados pelo Provincial (Rui Vicente). Já que os cristãos novos eram muito unidos entre si, o Provincial era suspeito de ser um deles, argumentava Fernando de Meneses.

Nuno Rodrigues, além do Provincial, também seria, de acordo com Fernando Meneses, um dos jesuítas cristãos velhos que "tinha afeição exorbitante a alguns" cristãos novos.

De acordo com informação que Fernando Meneses afirmou ter recebido de Duarte de Sande, todos os que estavam no Ceilão estavam dispostos a serem superiores no Rosairo. Graças às pressões do capitão de Malaca João da Gama, Gomes Vaz satisfez suas “ambições” ao conseguir ser o reitor do Colégio de Malaca (1579).

Fernando Meneses não concordava que Malaca e as demais casas pretendidas pelos cristãos novos fossem pequenas. Para ele, isso era um pretexto utilizado pelos cristãos novos. Pois em Malaca, argumentava, tinha "todos os tratos e escala de todo o mundo.”

Ele pedia a Deus que Nuno Rodrigues e o Provincial Rui Vicente não se arrependessem. Fernando Meneses estava querendo dizer que o fato de Gomes Vaz ser o reitor do Colégio de Malaca poderia causar problemas para os dois amigos dos cristãos novos.

Todo este relato foi transmitido a Fernando Meneses pelo padre Manuel Teixeira. Além deste, estavam diretamente envolvidos no caso de Gomes Vaz, Duarte Leitão e Bernardino. Duarte Leitão foi falar pessoalmente com o Provincial. O resultado desta conversa foi a demissão de Gomes Vaz, a qual ocorreu em $1581^{251}$.

\footnotetext{
${ }^{251}$ Ver a segunda carta de Fernando Meneses enviada em 31. 12. 1580 para o Vigário Geral Everardo Mercuriano tratando dos cristãos novos na Documenta Indica XII. Op. cit., pp. 182-83. Gomes Vaz, além de reitor do Colégio de Malaca foi procurador do Colégio de S. Paulo de Goa, da Província e da casa professa. No Diccionario Histórico de la Compañía de Jesús Biográfico-Temático, lê-se que sempre pesou sobre ele sua inculpável origem de cristão novo e que há muitos documentos afirmando que escandalizava por seu trato com os cristãos novos. Desempenhou a função de secretário da III Congregação Provincial (1588). Foi
} 
Estava assim consumada mais uma demissão de cristão novo de um cargo de comando na Companhia de Jesus.

Aproximadamente um ano após a demissão de Gomes Vaz, mais precisamente em dezembro de 1581, o reitor do Colégio de Goa, Nuno Rodrigues e conforme Fernando de Meneses, grande amigo de alguns cristãos novos - tomou uma atitude talvez inesperada. Escreveu para o novo Prepósito Geral, o padre Cláudio Acquaviva, tecendo duríssimas críticas ao envio de cristãos novos efetuado pelos superiores em Portugal para a Província de Goa.

Na avaliação do reitor do Colégio de Goa os cristãos novos somente serviam para dar trabalho, afrontar e desassossegar a Província. Ocupavam o lugar de outros que podiam servir, em muito, a nosso Senhor. Portugal se descarregava dos cristãos novos causando grande prejuízo à Companhia de Jesus no Oriente. Nuno Rodrigues considerou esta Política insensata e injustificável.

O Vigário Geral deveria fazer a escolha dos jesuítas a serem enviados. Que eles fossem bem escolhidos, quer dizer, "virtuosos e limpos no natural", isto é, cristãos velhos.

Nuno Rodrigues dizia está confiante e esperançoso na ajuda e no consolo que o Vigário Geral iria proporcionar à sua Província ao utilizar os critérios de escolha por ele indicados. Caso não houvesse nenhum com as qualidades por ele requeridas, concluía o reitor, seria melhor não enviar ninguém. Este seria o único remédio para a Província, do qual dependia todo o seu bem ${ }^{252}$.

Com esta carta fica evidente que os cristãos novos perderam um aliado importante no Oriente: o reitor do Colégio de Goa. Exatamente ele que não havia feito nenhuma objeção à indicação do cristão novo Lourenço Pinheiro para o cargo de vice-reitor daquele Colégio. Talvez tenha mudado de postura devido às possíveis pressões sofridas pelos mesmos que conseguiram a demissão de Gomes Vaz

enviado para Portugal sem motivo conhecido em 1610. Ver Charles E. S. I., e Domínguez, Joaquín Mª S. I. Op. cit., vol. IV, p. 3910.

${ }^{252}$ Ver carta de Nuno Rodrigues para o Geral Cláudio Acquaviva. Goa, 02. 12. 1581. In Documenta Indica XII. Op. cit., p. 490. 
(Manuel Teixeira, Duarte Leitão, Bernardino) e, muito provavelmente, de outros jesuítas com mentalidade semelhante.

Seis dias após a carta de Nuno Rodrigues, ou seja, em oito de dezembro de 1581, o Padre Diogo da Cunha, superior da Pescaria ${ }^{253}$, redigiu uma carta para o Vigário Geral Cláudio Acquaviva. Chamou a atenção do padre Geral dizendo que, como de costume, iria falar claramente. Se Cláudio Acquaviva entendesse que houve excesso no que havia dito, estava pronto para receber a penitência, dizia Diogo da Cunha.

Ele deixou o Prepósito Geral da Companhia de Jesus a par da reputação que os cristãos novos tinham na Pescaria e propôs a solução para o problema: "os cristãos novos nestas partes são muito conhecidos e notados por muito frios no serviço de Deus, assim dos de casa como dos de fora, pelo que não deviam para cá ser enviados, porque os que cá há nos sobejam.”

Esta foi uma denúncia inusitada. Os cristãos novos não deviam ser enviados para a Costa da Pescaria porque eram “frios no serviço de Deus”. Já havia cristãos novos em excesso. Incompetentes e mais do que suficientes. Esta era a condição dos conversos jesuítas na Costa da Pescaria descrita pelo padre Diogo da Cunha. O fato novo, por excelência, foi os jesuítas da Pescaria terem assumido, na pena de Diogo da Cunha, a inaptidão dos cristãos novos para serem bons cristãos, bons jesuítas, enfim, bons missionários.

Será que o jesuíta cristão velho Diogo da Cunha estava sendo realmente sincero ao afirmar que os cristãos novos que missionavam na Costa da Pescaria eram “frios no serviço de Deus”? O cristão novo Henrique Henriques foi o Superior da Pescaria durante vinte e oito anos (1548-76). Temos verificado uma presença marcante de cristãos novos nas missões orientais. Ocupando, por exemplo, cargos de reitor, superior regional, procurador e secretário de Congregação.

Na Pescaria comandada por Diogo da Cunha, o problema causado pelo recebimento de conversos não era, como diziam alguns jesuítas, a aversão que os 
portugueses tinham com eles, nem tampouco as consequências negativas com a Inquisição. Agora eles eram "frios no serviço de Deus".

Ou o padre Diogo da Cunha estava pretendendo justificar sua nova função na Companhia (Superior Regional) ou falava em nome de um movimento mais amplo, que lutava pela exclusão dos cristãos novos das missões nas Índias Orientais.

Aproximadamente um ano depois de ter sido um dos principais articuladores da campanha de demissão de Gomes Vaz do cargo de reitor do Colégio de Malaca, o padre Duarte Leitão (04. 01. 1582) escreveu para o Prepósito Geral Cláudio Acquaviva, solicitando-lhe a proibição da concessão de cargos de superiores para os cristãos novos. Quando eles ocupavam cargos desta natureza, dizia Duarte Leitão, era motivo de escândalo entre os "nossos e forasteiros". Na Província de Goa os cristãos novos eram mais conhecidos do que em qualquer outra parte do mundo. Estes foram os motivos que Duarte Leitão utilizou para justificar o seu pedido.

A quem o padre jesuíta Duarte Leitão estava se referindo quando disse que os “nossos" se escandalizavam ao ver um cristão novo ocupando cargo de superior na Companhia de Jesus? É difícil ter uma resposta definitiva. Mas no caso de Gomes Vaz, o capitão de Malaca Dom João da Gama foi o responsável pela escolha do cristão novo para o cargo de reitor daquele colégio. Portanto, Dom João da Gama não seria um dos “nossos” na contagem do padre Duarte Leitão ${ }^{254}$.

Logo a seguir, mais especificamente um dia depois da carta do padre Duarte Leitão (05. 01. 1582), o jesuíta Diogo Pinto, que também missionava em Malaca, escreveu para o Vigário Geral uma missiva com conteúdo semelhante.

O padre Diogo Pinto apontou dois fatores que constituíam o problema. Os conversos eram muito conhecidos por todos, e por mais virtuosos e cultos que fossem, os portugueses não lhes prestavam o respeito e a devoção que convinham a

\footnotetext{
${ }^{253}$ Mesmo cargo que havia sido ocupado por Henrique Henriques.

254 “Também V. P. deveria mandar que os que nesta Província dos nossos fossem conhecidos por cristãos novos não tivessem cargos de superiores por causa do grande escândalo que há nisso entre os nossos como entre os forasteiros, e neste Província são mais conhecidos que em todas as partes do mundo." Excerto da carta enviada para o Geral Cláudio Acquaviva. Malaca, 04. 01. 1582. In Documenta Indica XII. Op. cit., p. 550.
} 
um religioso jesuíta. Diante dessa situação, propôs que o Vigário Geral da Companhia não permitisse que os cristãos novos "tivessem governo". Caso esta proposta fosse adotada, argumentava Diogo Pinto, a Companhia de Jesus conservaria sua autoridade.

A dúvida é a mesma: quem eram esses portugueses que não respeitavam os cristãos novos? Poderiam ser todos, exceto o capitão de Malaca Dom João da Gama. Entretanto, é razoável supor que ao apoiar o cristão novo Gomes Vaz, D. João da Gama não tenha agido isoladamente. Afinal, o cargo de capitão era político. Que motivos ele poderia ter para tomar uma atitude que contrariava a todos os portugueses? Por razões estritamente pessoais? Seria algo muito arriscado e politicamente insensato.

\section{A TOLERÂNCIA DE CLÁUDIO ACQUAVIVA}

Em vinte e dois de dezembro de 1582 o Prepósito Geral da Companhia de Jesus Cláudio Acquaviva respondeu, através de uma instrução enviada para o novo Provincial ${ }^{255}$, às questões relativas aos cristãos novos nas missões orientais presentes nas cartas para ele enviadas. Não podia haver entre os jesuítas motivos para excluir os cristãos novos, nem tampouco deviam ser mal vistos pelos inacianos. Que todos eles fossem abraçados com a caridade cristã conforme a virtude de cada um. O desejo de excluí-los e vê-los de forma negativa eram sentimentos puramente profanos. Os cristãos novos eram da Companhia de Jesus como todos os demais, dizia o Geral.

Esta foi a posição do Geral Cláudio Acquaviva em relação ao recebimento dos cristãos novos e à forma pela qual deveriam ser vistos e tratados na Companhia.

Ao considerar a problemática dos cristãos novos nestes termos, o Vigário Geral da Companhia de Jesus reconheceu a discriminação dos cristãos velhos jesuítas contra os cristãos novos que missionavam no Oriente - como ficou evidente, 
por exemplo, na carta do padre Diogo da Cunha. Sua reprovação a este tipo de discriminação foi clara e inequívoca. Esta foi, portanto, a posição oficial da Companhia de Jesus em ralação à discriminação que os jesuítas cristãos novos vinham sofrendo dentro da própria Ordem nas Índias Orientais.

Porém, o Prepósito Geral fez concessões àqueles que pregavam e praticavam a discriminação contra os conversos. Achou que seria necessário não dar cargos de superiores ou ministérios importantes para os cristãos novos. Seus motivos: por serem tão mal recebidos entre os seculares, pelo bem do próximo, ou seja, para não ofender pessoas importantes como prelados e inquisidores.

Com o intuito de evitar que a Companhia de Jesus tivesse problemas com as "pessoas principais” o Geral Cláudio Acquaviva também discriminou os descendentes dos judeus. É provável que, ao assumir esta posição, ele também tenha satisfeito às mentalidades discriminadores existentes entre os próprios jesuítas cristãos velhos.

O Vigário Geral também confirmou e reforçou o discurso que apontava para a existência do sentimento anti-converso disseminado entre os portugueses ${ }^{256}$. Ele não tinha proposta de solução para este problema. Apenas disse para fazer o que fosse possível. Nada mais.

Ao término da instrução, chamou a atenção do futuro Provincial para pôr em prática suas orientações porque eram necessárias.

Exatamente um ano depois de escrita a Instrução, em doze de dezembro de 1583, o padre Antônio Rebelo escreveu para o Geral alertando que a Companhia de Jesus não devia guardar seus segredos e seu governo nem mesmo aos mais virtuosos e confiáveis dos cristãos novos, porque era muito grande o asco que "os destas partes a todos desta nação têm”. Alegavam, o padre Antônio Rebelo não diz quem, que como os cristãos novos estavam proibidos por lei de exercerem cargos públicos,

255 O Privincial Rui Vicente foi substituído pelo padre Alexandre Valignano em 1583. A. Valignano permaneceu no cargo até 1587. 
muito mais razão havia para o eclesiástico ter cautela a esse respeito pois, devido à sua importância (do eclesiástico), qualquer mácula, por menor que fosse, assumia grande importância.

O jesuíta cristão velho Antônio Rebelo concordou com esta opinião. Ele disse que, como demonstrava a experiência, havia motivos para duvidar dos cristãos novos $^{257}$. Ele pretendia convencer o Geral de que os cristãos novos não deviam ter cargos na Companhia de Jesus porque não eram confiáveis e não tinham a aprovação da população em geral.

Na Instrução de dezembro de 1582 Cláudio Acquaviva orientou o Provincial de Goa para não nomear cristãos novos para superior ou ministérios importantes onde fossem conhecidos e quando houvesse oposição dos prelados ou inquisidores. Havia em Cláudio Acquaviva possibilidades para promover os cristãos novos. Apesar dos limites por ele reconhecidos. Limites que poderiam ser impostos tanto pelos sacerdotes seculares quanto pelo Santo Ofício da Inquisição, mas não pelo povo ou pela falta de confiança nos cristãos novos, como queria Antônio Rebelo.

O que pode ter motivado o padre Rebelo a escrever para o Vigário Geral foi a nomeação feita pelo Provincial Alexandre Valignano. Ele nomeou o cristão novo Duarte de Sande para ser o superior da missão na China no mesmo ano que o padre Rebelo redigiu a carta (1583).

Ocorre que a China não era colónia portuguesa, ou seja, lá os cristãos novos não eram conhecidos como tal. E se fossem, seriam menos do que nas possessões portuguesas. Nem tampouco havia Inquisição. Portanto, a nomeação atendeu aos pré-reguisitos definidos pelo Geral. Duarte de Sande foi mantido no cargo. Talvez

\footnotetext{
256 "Isto entre os portugueses é coisa desesperada e que não tem remédio, porque está esta opinião muito metida nos corações dos homens.” Extrato da Instrução para o Novo Provincial da Índia Oriental. In Documenta Indica XII. Op., cit., p. 695.

257 "e a experiência que da nação se tem, tem mostrado poder-se com razão duvidar." Extrato da carta enviado para o Geral da Companhia de Jesus Cláudio Acquaviva. Goa, 12. 12. 1583. In Documenta Indica XIII. Op. cit.,. p. 416.
} 
sua competência de missionário prevaleceu sobre a discriminação do padre Antônio Rebelo $^{258}$.

Em 1585 a questão da presença dos jesuítas espanhóis nas missões portuguesas voltou a ser considerada. Não como um problema em si, mas sim como solução. O Provincial Alexandre Valignano escreveu para o jesuíta espanhol que missionava em Luzón (Filipinas), Antônio Sedeño, tentando convencê-lo e aos demais jesuítas espanhóis de que a sua Província desejava e amava muito a todos eles. Que não pensassem ao contrário. Já estavam missionando mais de trinta jesuítas espanhóis, naquele ano chegaram mais três e no ano anterior foram recebidos outros três. Sempre havia solicitado ao Geral que enviassem missionários de todas as Províncias, de preferência das espanholas. Nunca tinha sido diferente.

Não foi o que disse o padre Lourenço Mexia em Novembro de 1577, conforme vimos anteriormente. Porque a distorção dos fatos? Alexandre Valignano estava sendo “diplomata”. O poder político havia mudado. A União Ibérica era uma realidade. E a supremacia política estava com a Espanha.

Os padres Gomes Vaz e Duarte de Sande ${ }^{259}$ estavam na lista dos que estavam prontos para se tornarem professos ${ }^{260}$. Porém, ocorreu um problema. Ambos tinham a "falta natural". Alexandre Valignano não considerou Duarte de Sande um cristão novo, mas prevaleceu a opinião da maioria.

E como os conversos eram considerados infames entre os portugueses, 0 Provincial achou que poderia causar problemas torná-los professos. Um grupo de professos propôs que se consultasse o Vigário Geral e esperasse sua resposta. Criado o impasse, Alexandre Valignano resolveu que não iria fazer nenhum professo, seja cristão novo ou velho para evitar “desinquietação ou escândalo".

\footnotetext{
${ }^{258}$ O padre Antônio Rebelo missionava em Goa, sede da Província.

${ }^{259}$ Os pais de Gomes Vaz eram cristãos novos e a avó materna de Duarte de Sande era cristã nova.

${ }^{260}$ Os professos faziam os quatros votos solenes na igreja: pobreza, castidade, obediência perpétua (que incluía educar as crianças) e obediência especial ao Sumo Pontífice no que respeita às missões. Ver Constituições da Companhia de Jesus. Op. cit., pp. 166-67. Os professos se diferenciavam dos coadjutores formados e dos escolásticos porque estes faziam os votos simples, ou seja não solenes na igreja, e faziam o voto de obediência especial ao Papa. Ver Constituições da Companhia de Jesus. Idem, pp. 168-69.
} 
O Provincial propôs que a resposta do Geral fosse dada por carta. Ele era favorável à “promoção” dos dois cristãos novos. Chegou até a orientar a composição da missiva: "é bom que V. P. escreva em sua carta que, não obstante que estes dois sejam tidos por cristãos novos, ou na verdade o sejam, se façam professos"261.

Duarte de Sande e Gomes Vaz se tornaram professos, apesar da relutância de alguns jesuítas cristãos velhos. Não foi encontrado nenhum documento comprovando a existência de qualquer reação contrária por parte dos portugueses que tanto "infamavam" os cristãos novos.

Em 1587 o padre Alexandre Valignano, agora visitador no Oriente, escreveu para o padre Manuel Rodrigues - assistente em Portugal (1581-94), onde anteriormente havia sido Provincial (1574-80) -, com o intuito de fazê-lo entender a importância de enviar "bons sujeitos"262 para a Índia.

Desde que o Geral Everardo Mercuriano começou a enviar gente boa até àquele momento (1587), a Companhia, na avaliação de Alexandre Valignano, não tinha parado de crescer em número e qualidade da pessoas, nas casas, na renda, conversão, no proveito da cristandade, crédito, estima e reputação social. Tudo isso teria feito com que a Província se transformasse em outra: mais gente e de mais qualidade. Exaltava o visitador ${ }^{263}$.

A alusão do visitador foi relativamente clara. Os cristãos velhos eram a causa do sucesso da Companhia de Jesus. Em outras palavras, o fim ou as restrições ao envio de cristãos novos permitiu que as missões orientais alcançassem as metas que há muito tempo perseguia.

Transcorridos quinze dias após ter escrito a carta para o padre Manuel Rodrigues relatando as conquistas das missões nas Índias Orientais e sua respectiva

\footnotetext{
${ }^{261}$ Extrato da carta do padre Alexandre Valignano enviada para o Geral Cláudio Acquaviva tratando da "promoção de Gomes Vaz e Duarte de Sande. Goa, 14. 12. 1583. In Documenta Indica XIII . Op.cit., p. 444.

${ }^{262}$ Pode ser uma alusão ao envio de cristãos novos, ou melhor, ao fim da "remessa" de cristãos novos para as missões nas Î́ndias Orientais.

263 " $E$ se quer V. P. entender que importa na Índia mandar sujeitos bons, veja o que nela se tem feito desde o tempo que começou a governar V. P. Everardo, de santa memória, até agora: porque, assim como o Geral presente e passado tomaram a cargo de mandarem aqui muita e boa gente, assim foi a Companhia crescendo
} 
causa, Alexandre Valignano compôs uma instrução para o Procurador em Portugal das Missões da Companhia de Jesus no Oriente.

O tema da instrução era o envio de jesuítas para as Índias. Os missionários a serem enviados deviam ser hábeis, virtuosos e sãos. Mas se não preenchessem esses requisitos o Provincial e seus auxiliares deviam ser consultados. E caso não fossem aprovados, antes de serem dispensados, o Vigário Geral devia ser informado a respeito do que estava ocorrendo.

Caso preenchessem os requisitos acima mencionados, poderiam vir de qualquer nação, sem nenhuma restrição. Entretanto, não devia ser enviado nenhum cristão novo, mesmo os que fossem muito bons. O motivo: eram muito mal recebidos ${ }^{264}$.

Alexandre Valignano não especificou quem não recebia bem os cristãos novos. Disse apenas que eram muito mal recebidos. Portanto, é possível pensar que ele estava incluindo os próprios jesuítas. Aliás, era exatamente isso o que o visitador está querendo dizer de modo indireto, é o que fica subentendido.

Em abril de 1588 o visitador Alexandre Valignano redigiu, por ordem do Vigário Geral Cláudio Acquaviva, um documento denominado "Sumário das Regras para o Provincial da Índia". Neste sumário o Provincial foi orientado, em nome do "bem universal da Companhia", a despedir, o quanto antes, "as pessoas escandalosas" que causassem "prejuízo à Companhia"265.

Conforme está escrito em cartas de alguns jesuítas cristãos velhos, quem causava escândalo eram os cristãos novos. Portanto, as Regras de abril de 1588 autorizaram o Provincial da Índia a demitir os cristãos novos que se enquadrassem na categoria de "escandalosos" e causadores de "prejuízo à Companhia".

...”. Carta para o padre Manuel Rodrigues. Goa, 27. 11. 1587. In Documenta Indica XIV. Edited by Joseph Wicki S. J. and John Gomes S. J. Romae, 'Institutum Historicum Societatis Iesu,' 1979, p. 657.

${ }^{264}$ Ver Regimento para o Procurador da Índia que Reside em Portugal. In Documenta Indica XIV. Op. cit., p. 752.

265 "Para o bem universal da Companhia se deve advertir muito deveras que nãose sofrão por muito tempo pessoas escandalosas com prejuízo da Companhia, mas se use a tempo do remédio de despedir os que convém,... ." Extrato do "Summary of the Rules for the Provincial of India, put together by A. Valignano S. J., 
É verdade que o Sumário não se referiu diretamente aos conversos. Como também não deixa de ser verdade que os escandalosos poderiam ser qualquer jesuíta que causasse problema para a Ordem. Mas, como temos visto, na situação delicada em que se encontravam os cristãos novos na Companhia de Jesus naquele momento, não seria necessário grande esforço especulativo para concluir que a maioria dos “escandalosos,” senão todos, seriam de cristãos novos.

E se quisermos especular um pouco mais, não seria necessário um jesuíta cristão novo provocar qualquer escândalo. Ele mesmo, sua presença, sua existência na Companhia de Jesus poderia ser o "escândalo.”

Em novembro de 1589 o Provincial de Goa, Pedro Martins, escreveu para o Vigário Geral Cláudio Acquaviva traçando o perfil do jesuíta cristão novo Antônio $\mathrm{Vaz}^{266}$ :

“ (...) amigo de suas comodidades, é inclinado à boa vida, fala e conversava com pouco espírito, ou seja, com limitações. Gosta de ter devotos e fica incomodado quando os seus vão confessar com outros padres. Prega mediocremente. Dizem que é neófito - ou cristão novo. Antes de se tornar padre teve uma filha, da qual tem um neto. Há rumores de que tem um caso com uma mulher, mas parece que não é verdade. Sua única qualidade era ter muitos anos de Companhia devido à sua muita idade" ${ }^{267}$.

Ao mesmo tempo em que Pedro Martins expôs uma série de características negativas do cristão novo Antônio Vaz, ele mesmo informava ou Geral que o converso tinha sido recebido em São Tomé, onde foi superior. O paradoxo é

Visitor, by order of Cl. Acquaviva S. J., General. Goa, april 1588. In Documenta Indica XIV, Op. cit., pp. 836-37.

${ }^{266}$ Antônio Vaz missionou em Malaca e, segundo consta, se desentendeu com o também cristão novo Afonso de Castro. Após a contenda foi recebido pelos jesuítas de Goa. 
evidente. Se Antônio Vaz possuía tantas deficiências, como foi possível ser o superior de São Tomé? É certo que àquela altura já não era mais o superior. Mas este não foi o único caso, como visto anteriormente, de jesuíta cristão novo demitido de cargo de comando.

Não resta outra alternativa senão concluirmos que o padre Pedro Martins, Provincial de Goa, discriminou o cristão novo Antônio Vaz. A não ser que admitamos que a Companhia de Jesus não possuía capacidade para escolher os seus padres e, menos ainda, para eleger os mais capazes para os cargos importantes da Ordem. Portanto, o problema não era de método, e sim de mentalidade.

O padre Francisco Vieira, consultor da Companhia de Jesus, quando estava em Goa (1593) redigiu uma missiva para o Vigário Geral Cláudio Acquaviva, cujo tema era a casa professa de Goa. Havia um problema a ser resolvido. A casa exagerava na arrecadação de recursos, não deixando nada para Deus ${ }^{268}$. Por isso os jesuítas tinham a fama de cobiçosos.

Francisco Vieira reconheceu o grande talento do padre Gomes Vaz na obtenção de recursos. Ele era um dos professos que mais se destacava na arrecadação de dinheiro para a Casa Professa. Mas o consultor achou que ele exagerava. E que por ser cristão novo conhecido, o padre Gomes Vaz tornava-se ainda mais suspeito, argumentava o padre Francisco Vieira.

Foi punido por ser competente. Seu erro não foi sua eficácia, seu erro consistiu em superar os cristãos velhos. Seu "pecado" não foi arrecadar demais, e sim arrecadar o que devia ser arrecadado por outros. Não havia "pecado" em arrecadar, o seu "pecado" foi não deixar "nada” para ser arrecadado pelos cristãos velhos $^{269}$.

\footnotetext{
${ }^{267}$ Carta de Pedro Martins para o Geral Cláudio Acquaviva. Goa, 24. 11. 1589. In Documenta Indica XV. Roma Documenta Indica XVI. Edited by Joseph Wicki S. J. and Jonh Gomes S. J. Roma, Institutum Historicum Societatis Iesu, 1984, p. 401.

${ }^{268}$ Talvez seja uma referência á igreja da Companhia ou à igreja secular.

${ }^{269}$ No Diccionario Histórico de la Compañía de Jesus Biográfico-Temático consta que era um "arrecadador eficaz de esmolas e zeloso pela conversão dos não cristãos." Ver Charles E. S. I., e Domínguez, Joaquín Mª S. I. Op. cit., vol. IV, p. 3910.
} 
O padre Gomes Vaz era o procurador da casa professa. Foi demitido. O consultor Francisco Vieira elogiou a medida dizendo que "fora muito bom tirá-lo um tempo, que Deus não lhes há de faltar”.

O cristão novo Gomes Vaz, além de ter sido o procurador da casa professa, foi também o procurador do Colégio de Goa e da Província de Goa. O demitiram de todos os cargos.

Em 1610 foi enviado para Lisboa. Estava com sessenta e oito anos de idade. Faleceu logo depois da chegada (1610). Provavelmente, não suportou o desgaste da viagem em função da idade avançada.

Assim encerra-se este capítulo. Todos os jesuítas de descendência judaica que se destacaram haviam perdido todas as conquistas que realizaram nas missões da Companhia de Jesus nas Î́ndias Orientais. Demitidos dos cargos que ocupavam e proibidos de exercerem qualquer função de comando na Ordem. Discriminados, estigmatizados e humilhados.

O anti-semitismo venceu nas missões orientais da Companhia de Jesus antes mesmo da aprovação do Estatuto de Limpeza de Sangue da Ordem. 


\section{CAPÍTULO V. A COMPANHIA DE JESUS E O SEU PAPEL NA INSTALAÇÃO DO TRIBUNAL DO SANTO OFÍCIO DA INQUISIÇÃO EM GOA}

\section{CRISTÃOS NOVOS NO ORIENTE}

A existência de cristãos novos que vieram de Portugal e que continuavam a chegar na "Índia” foi registrada pela Companhia de Jesus, mais especificamente pelo jesuíta Baltasar Dias, na época Vice-Provincial (1554-56) ${ }^{270}$. A maneira pela qual ele efetuou esse registro denota o grau de importância que a Ordem lhes atribuiu.

Ele se referiu à presença numérica, à participação no comércio e na política da "Índia” dos descendentes dos judeus. Baltasar Dias parecia estar assustado com a quantidade de cristãos novos: "está toda a Índia cheia”. Assim se expressando, nos dá a entender que, em função do grande número de habitantes ou em trânsito, os cristãos novos tornaram-se um grave problema que devia ser considerado, e solucionada de maneira rápida e definitiva.

Quanto à atividade comercial, razão principal da presença portuguesa no Oriente, o padre Baltasar Dias colocou os cristãos novos na condição de monopolistas de todo o comércio existente na "Índia”: “todo o trato em suas mãos”. É claro que uma notícia dessa natureza, ao chegar em Portugal, deve ter causado grandes repercussões, principalmente entre os comerciantes cristãos velhos. Enquanto que no Oriente, “constatações” como estas, ao serem divulgadas pela

\footnotetext{
${ }^{270}$ A província de Goa ficou sem provincial desde o ano da morte de Francisco Xavier (1552) até 1556, quando Gonçalo da Silveira assumiu o provincialato. Ver Rodrigues, Francisco. A Companhia de Jesus em Portugal e nas Missões. Esboço Histórico - Superiores - Colégios, 1540-1934. Op. cit., pp. 24-29, especialmente p. 24.
} 
Companhia de Jesus, devem ter causado impactos muito mais profundos nos comerciantes cristãos velhos que naquele momento lá se encontravam.

O inaciano Baltasar Dias nos dá a impressão de que estava conclamando os comerciantes cristãos velhos a reagirem contra a prática comercial exercida pelos cristãos novos no Oriente ao, indubitavelmente, super dimensionar a fatia do comércio pertencente aos conversos.

No plano político, ainda conforme o jesuíta Baltasar Dias, os cristãos novos encontravam-se em um nível de importância semelhante ao econômico. Porém, neste caso, ele apenas transmitiu uma notícia que, conforme esclareceu, era conhecida praticamente por todos: "e dizem que com suas dádivas já começam a governar e mandar a terra".

Apesar de ter alegado que essa notícia já circulava na “Índia” - ou seja, que não era inédita -, não diminuiu em quase nada a importância da participação do jesuíta na formação de um ambiente de temor em relação ao suposto controle político absoluto dos cristãos novos nos domínios portugueses do Oriente.

Entretanto, chamou-nos a atenção a ausência das possíveis implicações religiosas causadas pelos cristãos novos na "Índia”. Talvez porque essa não tenha sido a intenção de Baltasar Dias. Seu objetivo teria sido, exclusivamente, político.

Com a superioridade numérica e as supremacias econômica e política, os cristãos novos teriam os meios necessários para submeterem os cristãos velhos ao seu domínio. Ao levantar tais hipóteses, mesmo que indiretamente, o padre Baltasar Dias procurou criar um ambiente de tensão política entre ambos, com o intuito de provocar a reação dos cristãos velhos a fim de impedir a continuidade da ascensão dos conversos na vida política e econômica da “Índia”, além de dificultar ou proibir a vinda dos mesmos ${ }^{271}$.

\footnotetext{
271 "Dos outros cristãos novos, que vieram e vêm do Reino, está toda a Índia cheia e todo o trato em suas mãos, e dizem que com suas dádivas já começam a governar e mandar a terra.” Carta do padre Baltasar Dias para o provincial de Portugal, Diogo Mirão. Goa, 20. 12. 1555. In Documenta Indica III (1553-57). Op. cit., p. 408.
} 
Esta não foi a primeira vez que um jesuíta se referiu à presença de cristãos novos no Oriente. Em 1550 o padre Gaspar Bárzeo escreveu para os jesuítas de Coimbra informando-os que encontrou muitos cristãos novos em Ormuz vindos de Portugal e que tinham retornado ao judaísmo ${ }^{272}$. Em 16 de maio de 1546 o jesuíta Francisco Xavier solicitou ao rei de Portugal a instalação do Tribunal do Santo Ofício em Goa para reprimir os que "viviam na lei mosaica e seita mourisca e maometanos, 273 .

Os cristãos novos no Oriente também já tinham chamado a atenção das autoridades laicas. Martim Afonso de Sousa queixava-se, em 1535, do grande número que aportava na Índia. No ano posterior, 1536, o Dr. Jerônimo Dias informava ao rei, em tom de denúncia, que a quantidade de conversos não parava de crescer graças à conivência dos oficiais ${ }^{274}$. Diogo de Couto escreveu que a Índia começa a "inçar de cristãos novos" judaizantes ${ }^{275}$.

Em 1543 o vigário geral Miguel Vaz solicitou ao monarca português a instalação do Tribunal do Santo Ofício, e chamava a atenção para a grande quantidade de conversos residindo nas possessões portuguesas, ao mesmo tempo em que informava que eles não paravam de chegar e que esse fluxo continuaria ininterrupto $^{276}$.

272 Carta de Gaspar Bárzeo S. J., escrita no Colégio Bom Jesus de Ormuz em 24. 11. 1555. In Documenta Indica II, p. 77. Ver ainda a esse respeito outra correspondência do mesmo padre na Documenta Indica II, Op. cit., pp. 245-66.

273 "A segunda necessidade que a Índia tem para serem bons cristãos os que nela vivem é que mande $V$. A. a santa Inquisição porque há muitos que vivem na lei mosaica e seita mourisca, sem nenhum temor de Deus e vergonha do mundo.” In Salvador, José Gonçalves. Cristãos novos, Jesuítas e Inquisição. Aspectos de sua atuação nas capitanias do Sul, 1530-1680. São Paulo, Livraria Pioneira Editora. Editora da Universidade de São Paulo, 1969, p. 148.

${ }^{274}$ Ver Cunha, Ana Cannas da. Ver Cunha, Ana Cannas da. A Inquisição no Estado da Índia. Origens (153960). Estudos e Documentos. Lisboa, Arquivos Nacionais/Torre do Tombo, 1995, p. 29.

${ }^{275}$ Da Ásia ..., Década VI, Lisboa, Regia Officina Typographica, 1781, 1. VII, cap. V, pp. 92-93. Citado por Cunha, Ana Cannas da. Idem, p. 31.

${ }^{276}$ Cunha, Ana Cannas da. Idem, p. 30. 


\section{PRIMEIRA TENTATIVA DE INSTALAÇÃO DA INQUISIÇÃO}

Graças à intolerância destes e outros portugueses, em 6 de Março de 1554 houve uma tentativa frustrada de instalação da Inquisição em Goa, a qual não teve o apoio necessário do clero e das autoridades seculares. Foi visto acima que o Dr. Jerônimo Dias, por exemplo, deixou claro que os “oficiais” apoiavam os cristãos novos, e em 6 de dezembro de 1555 o jesuíta Belchior Carneiro escreveu para o companheiro de Ordem, Francisco de Borja, argumentando que ainda não havia chegado o momento para que o Tribunal do Santo Ofício começasse a atuar em Goa $^{277}$.

Uma carta com conteúdo semelhante foi escrita por Baltasar Dias S. J. em vinte de dezembro do mesmo ano (1555), a qual foi enviada para o provincial de Portugal, Diogo Mirão. Baltasar Dias, na época reitor do colégio de Goa (colégio São Paulo), solicitava ao provincial, em nome de todos os jesuítas, que ele pedisse para o Cardeal não autorizar a vinda da Inquisição naquele momento, porque ao invés de auxiliar na conversão, a dificultaria e não seria benéfica para os recémconvertidos $^{278}$.

\section{OS ESCRITOS BLASFEMOS}

Em 1557 sucederam na cidade de Cochim dois fatos marcantes para a história dos cristãos novos nas possessões portuguesas no Oriente. Foram encontrados dois escritos “blasfemos”"279, cuja autoria foi atribuída aos cristãos novos.

\footnotetext{
${ }^{277}$ Ver Documenta Indica III, op. cit., pp. 356-57.

278 "Pareceu-me lembrar a V. R. que - como a cristandade da terra é tão avexada e desfavorecida, assim do eclesiástico como do secular, senão dos religiosos, que não podem mais que falar, e os cristãos naturais naturalmente tímidos - tenho por muito provável e quase certo que nunhum se converterá se a Inquisição se entender neles e virem que castigam algum por ela. Os padres todos pedimos $a V$. R. queira falar nisto ao Cardeal e ver se os pode escusar deste jugo, e lá ficará tempo quando eles sentirem outros favores e estiverem mais fortes e instruídos na fé para poderem com tudo.” In Documenta Indica III, idem, p. 408.

${ }^{279}$ Não se sabe onde estão estes escritos atualmente. O primeiro teria sido encontrado na Sé de Cochim; o segundo localizado por um fidalgo de Cochim na Igreja dos dominicanos, e uma cópia teria sido entregue por um parente próximo dos cristãos novos ao seu confessor. Sobre o achado de ambos os escritos ver Carta do P. Gonçalo da Silveira escrita em 19. 12. 1557 e enviada para o Provincial Miguel de Torres. In Documenta
} 
Encontrava-se pregando na cidade o Provincial da Companhia de Jesus, Gonçalo da Silveira, quando foi encontrado o primeiro dos escritos (data em que a cidade comemorava o dia de Corpus Christi). Logo a seguir, apareceu o segundo. Diziam que Jesus estava no inferno e que o Cristo ainda não tinha vindo, e que os católicos eram mentirosos e sua fé uma falácia. Comparou os pregadores do Evangelho aos cães. O segundo escrito nomeava alguns cristãos novos.

Quando o primeiro escrito foi achado, os jesuítas Gonçalo da Silveira e Belchior Carneiro mantiveram-no em segredo e solicitaram ao vigário Pero Gonçalves que fizesse o mesmo. Foi somente após a descoberta do segundo que, conforme a vontade dos dominicanos Diogo Bermuldes e frei Nicolao e do fidalgo que o encontrou, os escritos tornaram-se conhecidos pelo público.

Os inacianos Gonçalo da Silveira e Belchior Carneiro assumiram o caso na condição de levá-los até às últimas consequências. Um grupo formado pelos dois jesuítas, franciscanos e dominicanos foi avisar ao Capitão de Cochim, Diogo Álvares Teles. Os dominicanos propuseram que se prendessem os nomeados no escrito e, com isso, se encerrasse o caso. Os dois jesuítas discordaram da proposta, argumentando que a matéria era de fé e grave. Os dominicanos recuaram e concordaram com o argumento.

Restava apenas saber se o vigário da cidade - Pero Gonçalves - tinha poderes para fazer a inquirição, já que ele não era o vigário geral. Constatou-se que o vigário estava habilitado para realizar a diligência.

Os cristãos velhos novos não estavam gostando das conversas que os cristãos novos tinham com os judeus de Cochim de Cima, de suas visitas à Sinagoga, a qual, segundo diziam, ajudaram a construir, e da circuncisão que alguns deles faziam em seus filhos. E quando souberam que eles tinham sido os autores dos escritos blasfemos, quase que os agrediram ${ }^{280}$.

Indica III, op. cit., pp. 760 - 65. Ver a carta de Belchior Carneiro também destinada a Miguel de Torres em 21. 12. 1557. In Documenta Indica IV, op. cit., p. 710.

${ }^{280}$ Ver carta de Belchior Carneiro para o Cardeal Infante D. Henrique, escrita em Goa em 20. 12. 1557. In Documenta Indica IV, op. cit., pp. 11-12. 
Ficou acordado que seria realizado um pregão oferecendo uma série de recompensas para quem denunciasse os autores dos escritos ${ }^{281}$ e que todos os escravos dos cristãos novos fossem depor a respeito dos escritos.

Iniciaram a devassa. O capitão Diogo Álvares Teles soube que estavam, sem sua autorização, investigando a vida dos cristãos novos. Ordenou que os escravos fossem embora. O padre Belchior Carneiro resistiu à ordem do capitão e travou-se uma longa e grave discussão entre os dois, com ameaças e agressões de ambas as partes.

O capitão autorizou, sob ameaça de excomunhão, apenas algumas prisões e, apesar das ameaças, continuou dificultando a inquirição. Efetuaram-se cerca de vinte reclusões acompanhadas do confisco dos bens.

Os Dominicanos Diogo Bermudes e Nicolao, os franciscanos e o vigário Ambrósio Ribeiro ${ }^{282}$ entendiam que não era necessário muito rigor nas inquirições e punições. Graças a essa postura, o padre Gonçalo da Silveira discordou e discutiu com um dos dominicanos tolerantes que participava das inquirições ${ }^{283}$.

O governador Francisco Barreto, o deão da Sé vacante Antônio Ranges de Castelo Branco, o vigário Ambrósio Ribeiro e o licenciado Francisco Álvares aprovaram as inquirições e prisões efetuadas em Cochim.

Quanto ao capitão Diogo Álvares Teles, este recebeu do governador ordem para apoiar as inquirições e, ao perceber que estava isolado, pediu perdão aos responsáveis pela devassa. Entretanto, após consultar o cabido e alguns desembargadores, o governador decidiu que o processo devia ser encerrado, porque o vigário não tinha a idade requerida para presidir o caso. Três desembargadores e

\footnotetext{
${ }^{281}$ As recompensas foram as seguintes: financeira (mil cruzados ou pardaos), caso um culpado denunciasse alguém seria perdoado, o escravo alforriado, e qualquer condenado pela justiça seria perdoado.

${ }^{282}$ Vigário geral de Goa.

${ }^{283}$ Ver Carta do P. Gonçalo da Silveira escrita em 19. 12. 1557 e enviada para o Provincial Miguel de Torres. In Documenta Indica III, op. cit., pp. 772-73.
} 
os dominicanos apoiaram, por escrito, a decisão ${ }^{284}$. E sugeriram que os presos fossem soltos sob fiança até a vinda do Arcebispo ${ }^{285}$.

O governador Francisco Barreto solicitou aos jesuítas envolvidos no caso um documento assinado concordando com os termos do encerramento da devassa. Os inacianos recusaram a proposta, temendo que o governador apresentasse 0 documento solicitado ao rei. Em seu lugar, entregaram um escrito composto pelo jesuíta Francisco Rodrigues e um teólogo dominicano ${ }^{286}$.

O vigário geral de Goa ordenou que a devassa fosse transferida para Goa. O jesuíta Gonçalo da Silveira se encarregou de efetuar a transferência. Ao chegar em Goa, convenceu o deão para que ele assumisse as funções de visitador e inquisidor ordinário.

Ao saber que havia uma articulação para criar uma visita inquisitorial em Goa, os cristãos novos reagiram contra a idéia, dizendo que ninguém em Goa possuía poderes para realizar a visitação. Concordaram com os conversos o governador, letrados e religiosos. Francisco Barreto, irritado, disse a Gonçalo da Silveira que esta não era a vontade de "Sua Alteza"287. O provincial da Companhia de Jesus insistiu com o governador e findou por convencê-lo de que o vigário geral tinha poderes para fazer a visitação.

Participaram da visitação, além do vigário geral Antônio Rangel de Castelo Branco, representantes da Companhia de Jesus, dominicanos e franciscanos.

Desde o início da devassa, ou seja, mesmo antes das prisões e dos confiscos, os padres jesuítas Belchior Carneiro e Gonçalo da Silveira foram duramente censurados pela população em geral: "Verdade é que a gente toda desde o princípio

\footnotetext{
${ }^{284}$ Ver a carta de Belchior Carneiro também destinada a Miguel de Torres em 21. 12. 1557. In Documenta Indica IV, op. cit., p. 712.

${ }^{285}$ Idem, ibidem. O padre Gonçalo da Silveira disse que foi o governador quem mandou soltar os presos, tanto de Cochim quanto de Goa, sob fiança, o que ele considerou ser uma abominação. Ver Carta do P. Gonçalo da Silveira escrita em 19. 12. 1557 enviada para o Provincial Miguel de Torres. In Documenta Indica III, op. cit., p. 775.

${ }^{286}$ Ver a carta de Belchior Carneiro também destinada a Miguel de Torres em 21. 12. 1557. In Documenta Indica IV, op. cit., p. 713.

${ }^{287}$ Extratos da Carta do P. Gonçalo da Silveira escrita em 19. 12. 1557 e enviada para o Provincial Miguel de Torres. In Documenta Indica III, op. cit., p. 766.
} 
deste negócio ao Padre Belchior Carneiro e a mim nos tinham por mais cruéis, por não dizer inteiros no negócio.” E após as prisões “os parentes e negociantes dos presos a nós achavam mais rigorosos, e então não se entendia, parece que adivinhavam o seguinte"288.

A crueldade dos jesuítas apontada pelo povo tem sua razão de ser nos métodos adotados pelos inacianos. Foi idéia deles fazer o pregão oferecendo uma série de recompensas para quem denunciasse os autores dos escritos. Isso permitiu que as testemunhas fossem induzidas a forjar uma série de mentiras em relação aos cristãos, a fim de receberem as recompensas prometidas no pregão.

Ladrões, assassinos ou quaisquer outros condenados pela justiça tiveram, assim, uma grande oportunidade ímpar para se livrarem das condenações, e os escravos dos cristãos novos uma grande chance de conseguirem a alforria. Está evidente que tais testemunhas não eram confiáveis. Aceitá-las como legítimas foi considerado um ato cruel por uma parcela da população.

Os parentes e parceiros comerciais dos cristãos novos acharam os jesuítas mais rigorosos ao perceberam que eles eram os mais interessados na devassa ${ }^{289}$. Além de verem seus parentes presos, o que não devia ser algo agradável, os familiares dos presos perderam o patrimônio da família, e os que negociavam com os cristãos novos, certamente, tiveram significativos prejuízos financeiros.

Mas para os jesuítas o que justificava tanta dedicação? Por que resolveram assumir o papel principal na devassa, radicalizando-a ao máximo, enfrentando a oposição do capitão, do governador, dos dominicanos, franciscanos e de autoridades seculares?

$\mathrm{O}$ argumento fundamental era a necessidade de erradicar as "heresias judaicas” em Cochim, as quais, segundo o padre Belchior Carneiro, eram do

\footnotetext{
${ }^{288}$ Carta do P. Gonçalo da Silveira escrita em 19. 12. 1557 enviada para o Provincial Miguel de Torres. In Documenta Indica III, op. cit., p. 765.

${ }^{289}$ Foi visto anteriormente que os jesuítas Gonçalo da Silveira e Belchior Carneiro foram contra a proposta dos dominicanos de punir somente os cristãos novos nomeados no segundo escrito e sugeriram fazer uma devassa geral em Cochim. Como também já foi mencionado, a sugestão não foi somente aceita, mas posta em prática.
} 
conhecimento geral ${ }^{290}$. A terra "estava muito peçonhenta", ou "desbaratada das coisas da fé."

Portanto, era necessário remover o "grande impedimento para o que se pretende nesta terra.” O padre Belchior (às vezes ocorre Melchior) Carneiro estava convicto de que estava prestando um "grande serviço para Deus”. Algumas heresias já foram mencionadas; os cristãos novos estariam frequentando a sinagoga dos judeus de Cochim de Cima, inclusive, teriam ajudado a construí-la e alguns deles circuncidaram seus filhos.

O padre Francisco Rodrigues considerou tão grave a situação que chegou a prever um cisma no Oriente ${ }^{291}$. Para evitar que ameaças como esta se concretizassem e a fim de combater com mais eficácia as heresias dos cristãos novos, Belchior Carneiro solicitou mais apoio do rei e do cardeal D. Henrique à Igreja que se encontrava "muito abatida"292.

Era necessário mostrar para os cristãos portugueses e nativos, e aos gentios que escândalos como aqueles - os escritos blasfemos - jamais voltariam a ocorrer. Além disso, evitar-se-ia que os judeus e mouros escarnecessem o catolicismo ${ }^{293}$.

Quando a visitação estava em curso o padre Melchior Nunes Barreto escreveu para o Geral da Companhia de Jesus, Diego Laínez, dizendo que havia esclarecido a todos que a participação dos jesuítas na visitação não se devia ao fato dos inquiridos serem cristãos novos e descendentes de judeus e que, portanto, não perseguiam a "nação"294 mas os "erros e heresias",295.

\footnotetext{
290 "E além disto havia pública voz e fama que estava aquela cidade cheia de heresias judaicas." Excerto da carta de Belchior Carneiro também destinada a Miguel de Torres em 21. 12. 1557. In Documenta Indica IV, op. cit., pp. 710-11.

291 “... e o p. mestre Francisco dizia que havia medo de uma cisma nestas partes.” Excerto da carta de Belchior Carneiro também destinada a Miguel de Torres em 21. 12. 1557. In Documenta Indica IV, op. cit., p. 711.

${ }^{292}$ Idem, ibidem.

${ }^{293}$ Ver Carta do P. Gonçalo da Silveira escrita em 19. 12. 1557 e enviada para o Provincial Miguel de Torres. In Documenta Indica III, op. cit., p. 774.

${ }^{294}$ Nação era um dos nomes utilizados para se referir aos judeus.

295 “... neste entendi para que conhecessem todos que, não por serem cristãos novos e da geração dos judeus, ajudamos a visitação contra seus erros, nem perseguimos a nação, mas os erros e heresias." Carta escrita em Cochim em 16 de Agosto de 1558. In Documenta Indica IV. Op. cit., p. 90.
} 
Entretanto, o padre Francisco Rodrigues não deixou assim tão claro que esses eram os verdadeiros propósitos dos jesuítas que participavam da visitação. Apesar de não terem encontrado os autores dos escritos blasfemos, relatou Francisco Rodrigues, foram prestados outros grandes serviços a "Deus Nosso Senhor”, a prisão de "cerca de vinte cristãos novos, entre homens e mulheres culpados em casos graves da Inquisição”. Após este breve relato, o reitor do colégio de Goa esperava que fosse do desejo de Deus que aquela terra ficasse limpa e pura "deste género de gente $^{, 296}$.

O fato é que os autores dos escritos não foram encontrados. Nem sequer os que constavam seus nomes. Portanto, é plausível que os escritos blasfemos tenham sido forjados a fim de servirem como pretexto para perseguir os cristãos novos. Porém, é provável que os cristãos novos mantivessem contato com os judeus de Cochim de Cima e que praticassem algum ritual judaico. O que se configuraria em heresia, portanto, da alçada da Inquisição.

\section{EM DEFESA DO TRIBUNAL DO SANTO OFÍCIO}

Em janeiro de 1559, após ter acompanhado o provisor na devassa realizada em Cochim, o padre Melchior Nunes Barreto ${ }^{297}$ defendeu, em carta enviada para a província portuguesa, a criação do Tribunal do Santo Ofício em Goa ${ }^{298}$. Para ele não havia um lugar onde a Inquisição fosse mais necessária do que aquele. Isso porque todos os cristãos (velhos, novos e gentios convertidos) conviviam livremente com os judeus, mouros e gentios. Portanto, segundo o jesuíta, era necessário isolá-los. E que viessem, junto com o Santo Ofício, “homens muito zelosos da honra de Deus,” que

\footnotetext{
296 “Quererá Nosso Senhor limpar e purificar esta terra que deste género de gente anda contaminada." Ver Carta enviada para Coimbra em 30 de novembro de 1557. In Documenta Indica III. Op. cit., pp. 717- 18.

${ }^{297}$ Participou, durante um mês, da devassa geral ocorrida em Cochim naquele ano (1559).

298 “Também nos negócios da devassa geral, que o provisor da Índia veio tirar a esta cidade este ano sobre as heresia de alguns maus cristãos desta terra, me ocupei um mês inteiro em que sempre assisti ajudando nisso ao provisor, do qual negócio, pelo segredo que se lhe deve, não falo mais, senão desejar e pedir a Nosso Senhor que traga Inquisição a estas partes....” Excerto da carta escrita em Cochim em 15 [?) de janeiro de 1559. In Documenta Indica IV. Op. cit., p. 243.
} 
pregarão "as coisas da fé" com "boa vontade porque todos têm necessidade de serem bem instruídos nelas" ${ }^{299}$.

Na carta que Melchior Nunes Barreto enviou para o Vigário Geral da Companhia de Jesus, Diego Lainez, está mais clara a função que ele atribuía à Inquisição. Ela agiria na consciência das pessoas, as quais "se encontravam muito largas graças à largueza da terra”. O Tribunal serviria como freio, um método corretivo, cujas peças seriam constituídas pelo "temor à afronta e confusão do cárcere e outras penas." Somente assim, "os lobos seriam apartados das ovelhas.” E, por fim, com a Inquisição, se evitaria "que os frutos feitos pelos padres fossem desfeitos por Satanás”, ${ }^{300}$.

Ele disse, na mesma correspondência, que era falsa a informação dada por alguns em Portugal de que a Inquisição provocaria a conversão de muitos cristãos ao muçulmanismo. E mesmo que fosse verdadeira, seria melhor perdê-los do que contaminar a fé dos bons cristãos, escreveu o jesuíta. Ou seja, o padre Melchior Nunes Barreto propôs duas formas complementares para garantir o sucesso das missões orientais: a repressiva, através da instalação do tribunal inquisitorial, e a persuasiva, que deveria ser executada por "homens muito zelosos da honra de Deus".

Na mesma correspondência, o padre Melchior Nunes Barreto defendeu a postura do também jesuíta Gonçalo da Silveira no caso dos escritos blasfemos, a qual foi considerada por “alguns” como sendo muito rigorosa ${ }^{301}$. Quem o censurou? Pessoas iletradas que, apesar de "regerem a terra", não entendiam a importância das "heresias e erros desta gente". E muitos daqueles que compreendiam algo a respeito, "não são tocados do zelo da honra de Deus tanto como o P. ${ }^{e}$ Dom Gonçalo.”

\footnotetext{
${ }^{299}$ Idem, ibidem.

${ }^{300}$ Carta escrita em Cochim em 15. 01. 1559. Idem, pp. 229-230.

${ }^{301}$ Isso comprova que o padre Gonçalo da Silveira foi o mais intolerante no caso em questão.
} 
Melchior Nunes Barreto S. J. ${ }^{302}$ constatou que havia um grau razoável de liberdade religiosa não somente em Cochim, mas nas demais missões orientais: “as consciências de muitos andam cá muito largas", por isso, "estranharam tão fina virtude como a do P. ${ }^{e}$ Dom Gonçalo". Aqueles homens tolerantes "queriam uma virtude mais dobradiça que condescendesse com as vontades dos homens, e assim ao meio chamam extremo, e à constância pertinácia”.

Ele finalizou a missiva advertindo o Geral que, se caso algum religioso dissesse ou escrevesse alguma coisa contra o Padre Gonçalo da Silveira, é porque não entendia "a fineza e inteireza da virtude do $P .{ }^{e}$ Dom Gonçalo, e a importância dos negócios da Inquisição”. E acrescentou: “e não porque não fosse necessário tudo o que o Padre fez e muito mais, se mais pudera fazer”. Ou seja, ele fez o que foi necessário, e mais faria se mais pudesse.

O pensamento de Gonçalo da Silveira S. J. em relação à Inquisição era muito semelhante ao de Melchior Nunes Barreto S. J. Ele escreveu para o inquisidor geral de Portugal, infante D. Henrique, informando-lhe que os católicos estavam se convertendo ao judaísmo, bramanismo e ao muçulmanismo. Quanto aos judeus, soube o jesuíta que em Cochim "existia infinita e perversíssima judiaria, e segundo falam, não muito encoberta". E que era do conhecimento de todos "que os judeus lançam a perder a Índia".

Solução encontrada pelo padre Gonçalo da Silveira para "salvar” a Índia: "Quanto aos judeus e maus cristãos, o remédio está cham, ${ }^{303}$ que é a Inquisição".

Por que a Inquisição seria o "remédio" mais indicado para "salvar" a Índia? Porque com o Tribunal do Santo Ofício da Inquisição ela traria "freio e governo". Com isso toda a gente se tornaria cristãos melhores do que os de Portugal, pois para isso não lhes faltava disposição: "E por outra parte creia $V$. A., se esta terra tiver

\footnotetext{
${ }^{302}$ Abreviatura de Companhia de Jesus. Quando assim utilizada, indica que a pessoa citada pertence à Companhia.

${ }^{303}$ Cham: dizer em voz alta, proclamar. Ou seja, está cham, no caso significa está claro, evidente.
} 
freio e governo, que se vê a gente melhor acostumada que a de lá e tem para isso disposição" 304 .

A inquirição continuou até $1561^{305}$, enquanto o Santo Ofício já tinha sido instalado em Goa em 1560.

\section{CHEGOU O MOMENTO DA INSTALAÇÃO DO TRIBUNAL}

\section{INQUISITORIAL}

Por que, apesar da tolerância religiosa que prevalecia nas possessões portuguesas no Oriente, inclusive por parte do clero, e da reprovação apontada por Belchior Nunes Barreto S. J., feita por "toda a gente" dos procedimentos inquisitoriais dos jesuítas Gonçalo da Silveira e Belchior Carneiro, o Tribunal do Santo Ofício estabeleceu-se em Goa? Ou seja, por que naquele ano (1560), ao contrário da tentativa frustrada de 1554, a Inquisição chegou em Goa?

Houve mudanças significativas na estrutura organizacional da Igreja no Oriente. Em 1558 foram criados os bispados de Cochim e Malaca, além da elevação do bispado de $\mathrm{Goa}^{306}$ a Arcebispado na mesma data ${ }^{307}$.

No mesmo ano (1558) teve início o vice-reinado de D. Constantino de Bragança. Ele substituiu Francisco Barreto que, como foi visto, resistiu à continuidade da inquirição e propôs que os cristãos novos detidos fossem soltos sob fiança. Filho do quarto Duque de Bragança, D. Jaime ${ }^{308}$, D. Constantino de

\footnotetext{
${ }^{304}$ Documenta Indica IV. Op. cit., pp. 2 e 3.

${ }^{305}$ Ver Cunha, Ana Cannas da. Op.cit., p. 143.

${ }^{306} \mathrm{O}$ bispado de Goa foi criado em 1534, após desmembramento do bispado do Funchal.

307 Ver Cunha, Ana Cannas da. Op.cit., p. 114.

${ }^{308} \mathrm{O}$ fato de D. Constantino ser filho de um Duque, portanto membro da alta nobreza portuguesa, auxilia no esclarecimento do fácil entendimento ocorrido entre ele e os jesuítas intolerantes liderados por Gonçalo da Silveira - o qual era filho do conde de Sortelha. Ao mesmo tempo em que, por exemplo, os desentendimentos que existiram entre o governador Francisco Barreto e o provincial da Companhia, Gonçalo da Silveira, se tornam mais compreensíveis em função do governador não ser membro da nobreza lusitana.
} 
Bragança governou a Índia até 1561. Era um fervoroso defensor da unidade religiosa nas possessões portuguesas ${ }^{309}$.

Uma nova geração de líderes jesuítas chegou nas Índias Orientais a partir de 1555, a qual se destacou na perseguição aos cristãos novos.

Um dos principais destaque desta geração, senão o personagem mais proeminente foi o Provincial Gonçalo da Silveira. Ele chegou à Índia em 1556. Era filho de Luís da Silveira, primeiro conde de Sortelha, portanto membro de família nobre lusitana. Se destacou na Corte de Lisboa por suas pregações. E talvez graças a esse mérito, ocupou o cargo de provincial de Goa (1556), o qual estava vago desde a morte do padre Francisco Xavier, ocorrida em 1552.

Outro jesuíta cristãos velhos iminente foi Belchior Carneiro S. J., personagem fundamental da devassa de Cochim, aquele que travou um debate decisivo com o capitão Diogo Álvares Teles a respeito da referida devassa. Era filho de família nobre coimbrã, primeiro reitor do colégio de Évora, governou a casa de São Roque em Lisboa. Em 1555 foi para a Índia na condição de bispo de Nicéia e coadjutor do patriarca da Etiópia.

Antônio de Quadros S. J. era membro de família nobre de Santarém. Seu irmão D. Manuel de Quadros foi bispo da Guarda. Em 1555 Antônio de Quadros foi enviado para as missões no Oriente, onde coadjuvou o presidente da devassa, Antônio Rangel de Castelo Branco até julho de 1559. Neste mesmo ano substituiu Gonçalo da Silveira na função de provincial, cargo ocupado até sua morte ocorrida em 21 de setembro de 1572.

O jesuíta Francisco Rodrigues, mais um dos “quadros” da Companhia de Jesus, chegou na Índia em 1556. Exerceu as funções de reitor do colégio São Paulo (Goa) entre 1556-65, e de Vice-Provincial de Goa entre 1572-73, também auxiliou o presidente da devassa geral Antônio Rangel de Castelo Branco entre 1557-59;

\footnotetext{
${ }^{309}$ Por exemplo, encontrava-se com os colonizadores portugueses com uma relíquia atribuída a Buda . Por ser muito venerada, o rei de Pegu ofereceu um resgate. D. Constantino de Bragança rejeitou e mandou o arcebispo de Goa, D. Gaspar Leão Pereira destruí-la. Ver a respeito Tratado de Todos os Vice-Reis e Governadores da Índia. Lisboa, Editorial Enciclopédia, 1962.
} 
quando o presidente precisou se ausentar, em 1558, Francisco Rodrigues o substituiu.

A presença destes novos dirigentes jesuítas de mentalidade intolerante e filhos da nobreza lusitana, a consolidação da presença católica com novos bispados, a criação do primeiro arcebispado no Oriente e o apoio político dado pelo vice-rei, e também filho da nobreza portuguesa, D. Constantino de Bragança a estes novos líderes, foram fatores determinantes para a instalação do Tribunal do Santo Ofício em Goa no ano de 1560.

A conjunção destas novas condições religiosas, sociais, políticas e econômicas resultou na consolidação da Inquisição em Goa. Para sermos mais específicos, a nobreza conservadora, representada principalmente pelos jesuítas envolvidos na inquirição e pelo vice-rei D. Constantino de Bragança, impuseram sua vontade sobre as forças políticas, econômicas e religiosas tolerantes que atuavam nas possessões orientais de Portugal.

\section{O PAPEL DA COMPANHIA DE JESUS E DA COROA PORTUGUESA NA} INSTALAÇÃO DO TRIBUNAL DO SANTO OFÍCIO EM GOA

Para Ana Cannas da Cunha a coroa portuguesa era a mais interessada na instalação do Tribunal do Santo Ofício em Goa. Por isso, segundo a autora, a corte lusitana desempenhou um papel preponderante na unificação religiosa representada pela presença do Santo Ofício:

“A posição vencedora, traduzida na forma como se decidiu a devassa iniciada em 1557 e nos moldes em que foi estabelecido o Tribunal em 1560, correspondeu ao primado do empenhamento régio quanto à obra de integração religiosa, à vontade política do poder central em criar na Índia um instrumento que, através da uniformização religiosa 
coerciva, agregasse as comunidades portuguesas, integrasse as minorias e anulasse as diferenças” ${ }^{310}$.

Os fatos revelados pela documentação até aqui analisada não confirmam esta conclusão nos termos em que Ana Cannas da Cunha a formulou. A iniciativa da inquirição e sua continuidade que resultaram na instalação da Inquisição em Goa coube principalmente aos jesuítas. O governador Francisco Barreto, o capitão de Cochim, Diogo Álvares Teles, e alguns desembargadores se opuseram ao rumo que os jesuítas estavam dando à inquirição como, por exemplo, as prisões efetuadas. Em 1560 o embaixador português em Roma, Lourenço Pires da Cunha, "levantava reservas sobre a repressão inquisitorial na Índia e o funcionamento do Santo Ofício em geral"311.

Entretanto, sabemos que o poder decisório nas questões relativas ao Tribunal do Santo Ofício da Inquisição no reino português pertencia ao monarca desde 1547. Afinal, foi ele quem autorizou a instalação da Inquisição em Goa. Porém, conforme a documentação à qual tivemos acesso, não foi ele quem tomou a iniciativa nem tampouco foi ele quem encontrou os motivos de instalá-la” .

Em dezembro de 1557, quando a inquirição já estava em curso, o jesuíta Belchior Carneiro solicitou ao rei de Portugal "que se guarde cá mais liberdade da igreja." Este fato comprova que interessa mais à Companhia de Jesus do que ao monarca a "uniformização religiosa coerciva".

A instalação do Tribunal do Santo Ofício em Goa ocorreu, principalmente, graças aos esforços dos jesuítas que participaram da inquirição iniciada a partir dos escritos blasfemos encontrados em Cochim. O fator político serviu de suporte essencial, mas não coube a ele a tarefa principal na realização do projeto inquisitorial de Goa. Mais claramente, no caso da instalação do Tribunal do Santo Ofício da Inquisição em Goa, o fator político, no caso a Coroa portuguesa,

\footnotetext{
${ }^{310}$ Cunha, Ana Cannas da. Op. cit., p. 148.

${ }^{311}$ Cunha, Ana Cannas da. Op. cit., p. 147.
} 
respondeu às demandas dos religiosos, principalmente dos padres da Companhia de Jesus $^{312}$. Isso foi o que demonstrou a documentação consultada.

Os motivos alegados pelos inacianos em insistirem na continuidade da inquirição, nas prisões e, posteriormente, demandarem a instalação do Tribunal do Santo Ofício em Goa eram religiosos, pois tinham a intenção, segundo eles, de evitarem os "erros e as heresias" dos cristãos novos. Diziam os jesuítas que a inquirição e a Inquisição eram, portanto, para preservar a "pureza da fé". Neste sentido, os inacianos queriam demonstrar que a essência de suas práticas inquisitoriais era religiosa. Todo o discurso justificando e defendendo suas ações estava fundamentado em necessidades que eles consideravam ser unicamente religiosas. Em função das alegadas necessidades, houve inclusive vários enfrentamentos com o poder político local. Como também já foi visto, o próprio embaixador de Portugal em Roma, Lourenço Pires, não era simpático ao Santo Ofício.

Apesar da justificava religiosa dada pelos jesuítas, suas intenções não se resumiam aos interesses estritamente religiosos. O Tribunal do Santo Oficio, não restam dúvidas, era uma instituição controladora da consciência religiosa dos indivíduos. Sua influência politica era significativa, e representava, ainda, uma importante fonte de renda auferida através dos confiscos dos bens dos prisioneiros. Portanto, a Inquisição era uma instituição que agregava em si interesses religiosos, políticos, culturais e económicos. Ou seja, quem tivesse o controle desta instituição ou dela participasse estava obtendo uma importante fatia dos poderes religiosos, políticos, culturais e económicos. A Companhia de Jesus pretendeu e conquistou uma fatia importante destes poderes através da sua participação no Tribunal do Santo Ofício da Inquisição ${ }^{313}$.

\footnotetext{
${ }^{312}$ As relações entre a política e a religião em Portugal, principalmente a partir de 1452 com o início do Padroado, tornaram-se "muito próximas. A coroa assumiu, através de bulas e breves da Santa Sé, uma série de prerrogativas que antes competiam à Igreja. Ver a respeito Cunha, Ana Cannas da. Idem, p. 102.

${ }^{313}$ Neste sentido concordamos com Paul Veyne quando disse que "Todo o poder, mesmo que seja espiritual, quer-se total.” Veyne, Paul. Como se Escreve a História. Lisboa, Edições 70, 1983, p. 197
} 
No período transcorrido entre janeiro de 1557 e janeiro de 1559 - o qual coincidiu com a inquirição provocada pelos escritos blasfemos - ocorreram dois fatos que envolveram jesuítas e cristãos novos que merecem ser aqui considerados.

Em treze de janeiro de 1558 o padre Francisco Pérez escreveu para o provincial de Portugal, Miguel de Torres, relatando a denúncia que o jesuíta Belchior Carneiro havia feito ao vigário de Cochim, Pedro Bonçaves (sic), contra um cristão novo português.

Um judeu que havia se convertido em Malaca disse ao padre Belchior Carneiro que um cristão novo de Portugal teria dito para ele, entre outras coisas, que "bem ruim é homem que deixa sua lei por tomar outra." Ao ser informado do ocorrido através do padre Belchior Carneiro, o vigário ordenou a prisão do cristão novo. Entretanto, foi libertado após pagar fiança ${ }^{314}$.

Um ano depois, ou seja, em janeiro de 1559 o padre Melchior Nunes Barreto escreveu uma carta a qual foi enviada para Portugal. Nela, o jesuíta trata do caso de um "cristão novo rico, pestilento nesta terra, sendo compreendido em anormalíssimo pecado na nau em que veio de Portugal e depois em Goa.

Seu pecado, dizia o padre, era “digníssimo de fogueira”315. O cristão novo já havia sido degredado para "umas ilhas" mas, naquele momento, encontrava-se em Cochim onde "perseverava em sua maldade."

Após receber algumas denúncias, o jesuíta Melchior Nunes Barreto se dirigiu ao capitão Diogo Álvares Teles pedindo-lhe explicações porque ele ainda não havia prendido o denunciado. O capitão respondeu que não se encontrava em Cochim e que, portanto, não sabia nada sobre o caso.

O inaciano não desistiu. Ao saber onde o cristão novo se encontrava, foi imediatamente até à fortaleza - era noite - e convenceu que o capitão efetuasse a prisão. Salientou que não queria que o condenasse à pena de morte, pois desejava apenas “impedir esta peste, que não pudesse causar dano a tantos”.

\footnotetext{
${ }^{314}$ Ver Documenta Indica IV. Op. cit., pp. 39-40.

315 Tratava-se de um caso de sodomia.
} 
O prisioneiro foi enviado para Goa. Ao que tudo indica foi assassinado, ou queimado ou jogado ao $\operatorname{mar}^{316}$.

Estes dois casos ilustram que a perseguição efetuada por membros da Companhia de Jesus entre 1557 e 1559 contra os cristãos novos não ficou restrita aos escritos blasfemos e às inquirições daí decorrentes - as quais, como já foi visto, desempenharam um papel decisivo no processo que redundou na instalação do Tribunal do Santo Ofício em Goa.

316 “Parece-me que ou o queimarão em Goa ou lhe deram fundo nesse mar.” Excerto da carta escrita pelo padre Melchior Carneiro em Cochim em janeiro de 1559. In Documenta Indica IV. Op. cit., p. 244. 


\section{CAPÍTULO VI. A INQUISIÇÃO E A ATUAÇÃO DA COMPANHIA DE JESUS EM RELAÇÃO AOS CRISTÃOS NOVOS EM GOA, PERU E BRASIL}

SERVIÇOS PRESTADOS À INQUISIÇÃO E PELOS JESUÍTAS E OS

\section{CONFLITOS DECORRENTES}

Em 1560 o Tribunal do Santo Ofício de Goa já tinha o seu inquisidor maior $^{317}$, o arcebispo de Goa D. Gaspar de Leão Pereira ${ }^{318}$. Ele demonstrou que era um verdadeiro e incondicional aliado da Companhia de Jesus. Disse para Melchior Nunes Barreto, por exemplo, que estava disposto a seguir as orientações dos jesuítas a respeito do governo do Arcebispado, e que todas suas decisões a serem tomadas seriam inspiradas pelos inacianos e que "não fará nada por sua cabeça".

Esta aparente submissão de D. Gaspar de Leão Pereira diante da Companhia de Jesus foi, talvez, uma forma dele expressar o reconhecimento do empenho e dedicação dos jesuítas no processo de instalação do Tribunal do Santo Oficio em Goa, do qual ele era agora o inquisidor geral.

Quanto à participação da Companhia na Inquisição, o padre Melchior Nunes Barreto acreditava que o inquisidor maior contaria com os jesuítas, "ao menos para dar as sentenças”, o que não era pouco, pois as sentenças dadas pelos jesuítas serão motivo, no futuro, de um debate intenso no interior da Ordem. Seria praticamente impossível a escolha de algum jesuíta para o cargo de inquisidor, já que com o inquisidor maior, vieram mais dois inquisidores. Número compatível com o Tribunal de Lisboa, por exemplo.

Os jesuítas, representados aqui por Melchior Nunes Barreto, estavam dispostos a auxiliar o inquisidor maior assinando as sentenças do Santo Ofício,

\footnotetext{
${ }^{317}$ Era assim que os portugueses se referiam ao inquisidor geral.

${ }^{318}$ Chegou em Goa em 1559, tomou posse em 1560, permaneceu no cargo até 1567. Com ele também vieram os inquisidores Aleixo Dias Falcão e Francisco Marques Botelho. Ver Baião, Antônio. A Inquisição em Goa.
} 
dando continuidade, assim, ao trabalho que já vinham desenvolvendo desde as inquirições iniciadas em 1557 a partir dos escritos blasfemos ${ }^{319}$.

Como havia previsto o padre Melchior Nunes Barreto, o inquisidor maior, D. Gaspar de Leão Pereira, pediu auxílio aos jesuítas. O próprio Melchior Nunes Barreto foi um dos que "estava na Inquisição por assim me pedir o inquisidor"320. Em 1561 já confessavam os prisioneiros do Santo Ofício: "Vão também os padres confessar nas cadeias públicas e cárceres da Inquisição”,321.

Quando ocorreu o primeiro auto-de-fé em Goa em 1562, o inquisidor maior convidou o provincial da Companhia de Jesus, padre Antônio de Quadros, para ser o pregador. O convite foi aceito. Todos os presentes ficaram muito satisfeitos com a pregação do jesuíta: "Havendo-se de pregar no primeiro auto da Inquisição que nesta cidade se fez, a ele lhe pediu o Senhor Arcebispo a fizesse, a qual fez com muita satisfação de todos”322.

Em 1564 realizaram-se dois autos-de-fé em Goa. Em ambos pregou o padre Francisco Rodrigues S. J., reitor do Colégio de Goa. A satisfação dos ouvintes foi comparável à sentida na pregação do padre Antônio de Quadros durante o primeiro auto realizado em Goa. Talvez ainda maior, porque é provável que houvesse mais público: "Neste ano se fez duas vezes o auto da santa Inquisição nesta cidade, e em ambos pregou o padre Francisco Rodrigues com grande satisfação dos ouvintes que eram muitos (grifo nosso)"323.

No auto-de-fé realizado no ano seguinte, 1565, Francisco Rodrigues foi mais uma vez o pregador. A qualidade das pregações dos jesuítas nos autos-de-fé era um

\footnotetext{
Tentativa de História da sua Origem, Estabelecimento, Evolução e Extinção. Vol. I. Lisboa, Academia das Ciências de Lisboa, 1945, pp. 183-84.

${ }^{319}$ Sobre as afinidades entre D. Gaspar de Leão Pereira e a Companhia de Jesus ver a carta de Melchior Nunes Barreto enviada para o Vigário Geral da Companhia de Jesus, Diego Lainez. Goa, 09. 12. 1560. In Documenta Indica IV. Op. cit. pp. 818-19.

${ }^{320}$ Ver carta de Melchior Nunes Barreto enviada para a Europa. Cochim, 31. 12. 1561. In Documenta Indica V. Op. cit., documento 64.

${ }^{321}$ Extrato da Carta de Ludovicus Frois S. J. para a Provínvia Portuguesa. Goa, 01. 12. 1561. . In Documenta Indica V. Idem, p. 255.

${ }^{322}$ Excerto da Carta de Baltasar da Costa S. J. para Sociis Lusitanis et Aliis Europaies. Goa, 04. 12. 1562.

${ }^{323}$ Carta de Jorge Caldeira S. J. para Ex Comm. Sociis Europaies. Goa, 11. 12. 1564. In Documenta Indica VI. Edidit Ioseph Wicki S. I. Romae, Apud “Monumenta Historica Soc. Iesu,”. 1960, pp. 357-58.
} 
dos fatores responsáveis pela presença do grande número de pessoas: "grande auditório e com muita satisfação porque a pregação é muito erudita e por serem os nossos muito aceitos”324. E Francisco Rodrigues vinha se destacando entre os jesuítas pregadores, já que pregou em três autos consecutivos.

Além de confessarem os prisioneiros do Santo Ofício e pregarem nos autosde-fé, alguns jesuítas, atendendo sempre aos “rogos” do Arcebispo D. Gaspar de Leão Pereira e dos inquisidores D. Gaspar Dias Falcão e Francisco Marques Botelho, serviam ao Tribunal como deputados ${ }^{325}$ e assinavam as sentenças inquisitoriais ${ }^{326}$.

O padre Melchior Nunes Barreto esclareceu os motivos pelos quais os jesuítas trabalhavam para o Tribunal do Santo Ofício de Goa. Não era apenas para atender aos pedidos dos inquisidores. Havia a necessidade de ajudar na sustentação da fé, evitar que a fé e o serviço de Deus fossem desmoralizados. Em Goa não havia teólogos nem pessoas suficientemente preparadas e nas quais pudessem "confiar negócio de tanta importância.” Caso os jesuítas se afastassem da Inquisição de Goa, dizia Melchior Nunes Barreto, a Companhia de Jesus sofreria uma grande perda moral $^{327}$.

Melchior Nunes Barreto S. J. deixou muito claro qual era a concepção que os jesuítas que missionavam em Goa naquele período tinham da Inquisição. Era uma instituição a serviço da fé e de Deus. Portanto, de grande importância para o catolicismo, cujos servidores tinham que estar capacitados para exercerem funções que os inacianos entendiam ser de grande significado divino.

Entretanto, o padre Diogo Mirão, quando se encontrava em Roma como assessor do Vigário Geral Francisco de Borja, escreveu para o provincial de Goa, padre Antônio de Quadros, dizendo-lhe que era inconveniente para a Companhia de

\footnotetext{
${ }^{324}$ Excerto da carta de Jorge Caldeira S. J. par Diogo Mirão. Goa, 06. 12. 1565. Documenta Indica VI. Op. cit., p. 611.

325 Jesuítas deputados da Inquisição de Goa em 1566: Antônio de Quadros, Francisco Rodrigues e Petrus Ramires. Ver Baião, Antônio. Op. cit., pp. 167-68.

${ }^{326}$ Ver carta de Melchior Nunes Barreto S. J. para o Vigário Geral Francisco de Borja. Cochim, 20. 01. 1566. In Documenta Indica VI. Op. cit., pp. 728-29.
} 
Jesus a participação no Tribunal do Santo Ofício. Por estarem a serviço da Inquisição, dizia Diogo Mirão, os jesuítas ficavam impossibilitados de missionar em outros lugares. E que, além disso, as tarefas exercidas pelos inacianos no Santo Ofício contrariavam as Constituições da Companhia, a qual proibia expressamente ofícios e autos de jurisdição, conforme $4^{\mathrm{a}}$ parte, $11 \S 3^{\mathrm{o} 328}$. Portanto, seria possível e até mesmo aconselhável dar conselho e parecer, mas não assinar sentenças ou autos que tenham força jurídica, argumentava Diogo Mirão ${ }^{329}$.

O padre Francisco Rodrigues se reuniu com outros consultores para avaliarem a carta de Diogo Mirão. Concluíram que se a Companhia de Jesus se afastasse de modo definitivo do Santo Ofício, "se impediria muito serviço de Deus N. S.”. Ficariam profundamente escandalizados os inquisidores, o Arcebispo e todos os que zelavam pela fé. Finalmente, chegaram a uma solução mediadora: “Temperar-se de maneira este negócio que nem fôssemos tão fáceis, como até agora éramos para aceitar ser deputados, nem resistíssemos a isso que recrescesse algum escândalo ou detrimento no serviço de Deus”. Esta decisão ficaria em vigor até receber orientações do Vigário Geral ${ }^{330}$.

Os “ares” de Goa não eram os mesmos que se respirava em Roma. Mais claramente, a intolerância religiosa dos jesuítas em Goa demonstrava estar muito mais intensa do que entre os inacianos residentes em Roma.

Em outubro de 1567, Melchior Nunes Barreto já conhecia a decisão de Francisco de Borja. Estava proibido pelo Vigário Geral que os jesuítas assinassem as sentenças dos condenados pelo Santo Ofício. O motivo da proibição: evitar que a

\footnotetext{
${ }^{327}$ Idem, ibidem.

328 "Como a tranquilidade da vida religiosa e as ocupações espirituais não permitem à Companhia as distrações e outros inconvenientes que resultariam do ofício de juiz em questões cíveis e criminais, não se aceitará jurisdição deste gênero que a Companhia tenha de exercer por si mesma, ou por outros dela dependentes.” Constituições da Companhia de Jesus. Op. cit., p. 147.

${ }^{329}$ Ver carta do padre Melchior Nunes Barreto para o Francisco de Borja, Prepósito Geral. Cochim, 20. 01. 1566. Documenta Indica VI. Op. cit., p. 729. O padre Diogo Mirão permaneceu como assistente de Francisco de Borja até 1573. A partir deste ano não foi encontrada nenhuma informação a seu respeito, a não ser a data da sua morte, ocorrida em 1590.

${ }^{330}$ Carta do padre Melchior Nunes Barreto para o Francisco de Borja, Prepósito Geral. Cochim, 20. 01. 1566. Documenta Indica VI. Op. cit., p. 729-30.
} 
Companhia fosse odiada, já que as sentenças comprometiam diretamente a vida e a honra das pessoas.

Estava permitido qualificar proposições como consultores, caso fossem demandados ${ }^{331}$.

Entretanto, em janeiro de 1569, Melchior Nunes Barreto escreveu para Francisco de Borja dizendo que iria mostrar ao padre visitador Gonçalo Álvares ${ }^{332} \mathrm{e}$ ao provincial Antônio de Quadros a carta do Geral proibindo os jesuítas de assinarem as sentenças do Santo Ofício, para que ambos executassem a ordem recebida: "e também o que manda que os nossos não assinem nem dêem sentença dos condenados pelo santo Ofício, eu mostrarei a carta ao $P .^{e}$ visitador e ao $P .^{e}$ Provincial para que ponham em execução o que V. P. manda"333. Isso significa que a proibição de 1567 não foi posta em prática. Portanto, devido à resistência dos jesuítas inquisidores de Goa, Francisco de Borja foi obrigado a escrever uma missiva para formalizar a proibição feita por ele, talvez informalmente, em 1567.

Uma carta escrita em 12 de dezembro de 1567 pode esclarecer, apesar da linguagem relativamente obscura, a desobediência dos jesuítas a serviço da Inquisição de Goa:

"O arcebispo Dom Gaspar se tem mostrado amigo da Companhia, ajudando-se muito dos nossos Padres em obras de nosso Instituto (grifo nosso). O mesmo faz o arcebispo Dom Jorge que lhe sucedeu, o qual não somente enquanto Bispo de Cochim, mas também agora depois que é Arcebispo de Goa, trata os nossos com muito amor e caridade" (grifo nosso).

\footnotetext{
${ }^{331}$ Carta de Dionísio Vasquez sob comissão de Melchior Nunes Barreto. Cochim, 27. 10. 1567. In Documenta Indica VII. Op. cit., p. 319. Carta sem destinatário especificado.

${ }^{332}$ Visitador entre 1568-73.

333 Trecho da carta do padre Melchior Nunes Barreto enviada para o Vigário Geral Francisco de Borja. Cochim, 22. 01. 1569. In Documenta Indica VII. Op. cit., p. 659.
} 
Quais seriam as “obras do nosso instituto”? Como se manifestava, na prática, o "amor e a caridade" dos dois inquisidores? Não está descartada a hipótese de favores materiais, como ocorreu, por exemplo, em 1561, quando o bispo dominicano, Jorge de Santa Luzia, doou à Companhia de Jesus a igreja anexa à Sé de Malaca ${ }^{334}$.

Cerca de três meses após a morte do jesuíta Antônio de Quadros, ocorrida em 21 de setembro de 1572, o prior dos dominicanos disse que a Inquisição devia chorar a morte do inaciano devido à grande obra que ele prestou ao Tribunal ${ }^{335}$. Essa é uma comprovação, inquestionável, da importância dos serviços prestados pela Companhia de Jesus à Inquisição goesa.

Portanto, a Inquisição, através dos inquisidores gerais, pode ter recompensado os serviços que a Companhia de Jesus lhe prestou através de diversas formas, inclusive material e financeiramente.

Entre janeiro de 1569 e novembro de 1575, a documentação consultada não voltou a considerar o problema da assinatura das sentenças do Santo Ofício. Neste período os jesuítas continuaram confessando os condenados e instruindo os prisioneiros do Tribunal, além de permanecerem como pregadores nos autos-de-fé.

Entretanto, em dezembro de 1575, entre os dias 06 e 18, houve uma reunião preparatória para a primeira Congregação Provincial. Quinze jesuítas estavam reunidos na ilha de Chorão. Uma das questões discutidas foi a participação da Companhia de Jesus no Tribunal do Santo Ofício de Goa. Apenas um dos quinze presentes - Francisco Dionísio - foi favorável à assinatura das sentenças pelos inacianos. Ele defendeu sua posição argumentando que “ (...) não se podia deixar de acudir à Inquisição, ao menos no momento de dar a sentença e em outras questões graves, porque há muita falta de homens doutos e que tenham segredo e o coração livre de paixão, o qual é muito necessário para aquele ofício. Todavia não

\footnotetext{
${ }^{334}$ Ver carta de Jerônimo Fernandes S. J. Malaca, 02. 12. 1561. In Documenta Indica V. Op. cit., pp. 310-11.

${ }^{335}$ Carta do p. Fr. Salvador Cortês para o Geral. Cochim, 15. 01. 1573. In Documenta Indica VIII. Edidit Ioseph Wicki S. I. Romae, Apud "Monumenta Historica Soc. Iesu” Institutum Historicum Societatis Iesu, 1964, p. 647.
} 
sejam nossos ordinários em fazer os processos”. Ou seja, a Companhia devia continuar assinando as sentenças porque seus padres, segundo Francisco Dionísio, eram competentes, confiáveis e imparciais. Apesar destas qualidades, o jesuíta não achou conveniente que os inacianos participassem dos processos inquisitoriais.

Os demais jesuítas consideraram que a Província de Goa não deveria participar da Inquisição porque o Tribunal era muito odiado e ao mesmo tempo temido. O maior motivo do medo das pessoas era que os jesuítas descobrissem suas consciências aos inquisidores: “ (...) não nos entretemos por nenhum caso no santo ofício da Inquisição, porque é muito odioso e que causa muito medo aos homens, principalmente havendo de descobrir-nos suas consciências.”

Entretanto, os catorze jesuítas contrários à presença da Companhia de Jesus no Santo Ofício fizeram uma ponderação que, na prática, anulava a posição assumida. Caso o inquisidor maior os obrigasse, diziam eles, a Companhia deveria servir ao Tribunal: "não nos obrigando o preceito do Cardeal como Legado e inquisidor maior, não nos entretemos por nenhum caso no santo ofício da Inquisição...”336.

Ocorre que a Companhia de Jesus, formalmente, não era obrigada a obedecer à Inquisição. Portanto, o inquisidor maior não tinha poderes legais para obrigar os jesuítas a participarem do Tribunal do Santo Ofício. Francisco de Borja, o Vigário Geral da Companhia que proibiu os jesuítas de assinarem as sentenças, havia falecido há três anos. Em seu lugar encontrava-se o padre Everardo Mercuriano ${ }^{337}$.

Em janeiro de 1576, o visitador de Companhia de Jesus, padre Alexandre Valignano $^{338}$, pediu ao Cardeal que em hipótese alguma chamasse os jesuítas para

\footnotetext{
${ }^{336}$ As deliberações preparatórias da primeira congregação geral da Província de Goa encontram-se na Documenta Indica X. Op. cit. Ver especialmente p. 277, na qual encontram-se as deliberações referentes ao Santo Ofício da Inquisição.

${ }^{337}$ Everardo Mercuriano permaneceu no cargo de Vigário Geral entre 1573-1580.

338 Alexandre Valignano natural de Chieti (Itália) ingressou na Companhia de Jesus, através de Francisco de Borja, em 29 de maio de 1566. Foi visitador da Índia (Província de Goa) por duas vezes: 1574-1583 e 15871596. Provincial entre 1583-1587. Ainda missionou na China e no Japão. Ver a respeito Carlos Sommervogel, S. J. Bibliothèque de la Compagnie de Jésus. Bruxelles, Oscar Schepens, Société Belge de Libraires, Paris, Alphonse Picard, Libraire des Archives Nationales et de l’École des Chartes, vol. VIII, 1898, pp. $403-404$ e
} 
servir à Inquisição. Motivo do pedido: muitos não revelariam suas consciências aos jesuítas ao saberem que eles faziam parte do Tribunal. Consequentemente, vários cristãos deixariam de ser ajudados pela Ordem. Em outras palavras, a participação da Companhia de Jesus no Santo Ofício prejudicava as confissões dos seus fiéis; razão pela qual o inquisidor maior não devia obrigar os inacianos a se "ocuparem do ofício da santa Inquisição”.

Alexandre Valignano assumiu com esse gesto uma postura favorável aos cristãos novos e reforçou, ao mesmo tempo, a deliberação de dezembro de $1575^{339}$. Foi o único jesuíta a procurar o inquisidor maior para tratar da questão relativa à participação da Companhia de Jesus no Santo Ofício.

Uma carta do Vigário Geral Cláudio Acquaviva ${ }^{340}$, provavelmente de 1583, comprova que a Companhia de Jesus continuava participando das "questões graves" do Santo Ofício. O Prepósito Geral escreveu ao Provincial dizendo-lhe que era totalmente inconveniente para a Ordem participar destas "questões”. Por isso não queria que continuasse este tipo de envolvimento com o Santo Ofício: “alguns dos nossos em Goa têm assistido aos atos da Inquisição alguma vez como inquisidor e alguma outra como agente ou comissário do Santo Ofício, o qual em nenhuma maneira convém. E assim desejo que V. R. o remedeie".

Cláudio Acquaviva alegou que em toda Europa, exceto em Portugal, a Companhia evitava que os inacianos fossem consultores do Santo Ofício. Para o Geral, o contexto português justificava que os jesuítas prestassem este serviço à Inquisição, mas não que se tornassem inquisidores. O mesmo raciocínio era válido para $\mathrm{Goa}^{341}$.

Nesta correspondência, o Vigário Geral não se referiu à ingerência dos inquisidores gerais na Província de Goa. Mas em 1584 ele requereu ao pontífice

Rodrigues, Francisco. A Companhia de Jesus em Portugal e nas Missões. Esboço Histórico - Superiores Colégios - 1540-1934. Segunda Edição. Porto, Edições Apostolado da Imprensa, 1935, p. 26.

${ }^{339}$ Ver carta assinada pelos jesuítas Alexandre Valignano, Rui Vicente (provincial) e Martinho da Silva. Goa, janeiro de 1576. In Documenta Indica X. Op. cit., p. 417.

${ }^{340}$ Cláudio Acquaviva iniciou seu generalato em 1581. Continuou na função de Vigário Geral até 1615. 
Gregório XIII um breve eximindo os jesuítas de servirem ao Santo Ofício nas Índias: "Do breve para eximir-nos dos Inquisidores se há também tratado, e encontrado muita dificuldade; esperamos que Sua Santidade o concederá.”342

Quais as causas das dificuldades para conseguir o breve papal? A resposta encontra-se na carta que Cláudio Acquaviva escreveu para Pedro de Ribadeneira (cristão novo espanhol) em 08 de outubro de 1584:

“O que o Ilustríssimo Cardeal [Quiroga, de Toledo] ${ }^{343}$ faz com a Companhia, não permitindo que por agora se exima de servir ao Santo Ofício nas Índias, porque nasce isso do zelo e amor com que atende a todas nossas coisas, contudo isso cá se considerará, e si outra coisa se julgar convir, se fará ofício com sua Ilustríssima Senhoria”344.

Contudo, em 10 de setembro de 1584 o papa Gregório XIII promulgou a bula Satis superque isentando a Companhia de servir à Inquisição ${ }^{345}$.

Em 20 de dezembro de 1586 Alexandre Valignano, agora provincial, escreveu para o Vigário Geral, Cláudio Acquaviva, informando-lhe que havia proibido os jesuítas de assistirem aos autos-de-fé no cadafalso. O inquisidor - Rui Sobrinho de Mesquita - não gostou da decisão porque os demais deputados do Santo Ofício assistiam aos autos juntos com ele, ou seja, no cadafalso.

\footnotetext{
${ }^{341}$ Ver carta de Cládio Acquaviva, Vigário Geral, para o Provincial da Índia. Roma, dezembro de 1583[?]. In Documenta Indica XII. Op. cit., p. 874.

${ }^{342}$ Trecho da carta do Padre Geral Cláudio Acquaviva para Juan de Atienza S. J. (missionário de Lima). Roma, 15. 06. 1584. In Monumenta Peruana III (1581-85). Por Antonio de Egaña. Roma, Institutum Historicum Societatis Iesu, 1961, documenta 105. A correspondência sugere que havia jesuítas no Peru contra a participação da Companhia no Santo Ofício. Inclusive pode ter sido idéia do próprio Juan de Atienza a solicitação do breve ao papa. Consideraremos a seguir, brevemente, a questão da relação da Companhia de Jesus com o Tribunal do Santo Ofício de Lima.

${ }^{343}$ Em 1563 Felipe II nomeou Gaspar de Quiroga y Vela para o Supremo Consejo de Justicia e para o Consejo de la Suprema (espécie de Tribunal de última instância da Inquisição espanhola). Foi o inquisidor geral da Espanha entre 1573 e 1594. Em 1773 também passou a fazer parte do Consejo de Estado. Tornou-se cardeal de Toledo em 1578. É provável que ele tenha influenciado na aprovação do decreto que impediu o ingresso dos cristãos novos na Companhia. Essa questão será considerada mais à frente.

${ }^{344}$ Trecho citado in Monumenta Peruana III. Op. cit., p. 469, nota 14.

${ }^{345}$ Conforme Marcocci, Giuseppe. Op. cit., p. 322. A bula Satis superque também foi citada em Monumenta Peruana III. Idem, p. 469, nota 14.
} 
Alexandre Valignano e demais jesuítas não entenderam o motivo pelo qual o Vigário Geral da Companhia de Jesus, Cláudio Acquaviva, restringiu às consultas a participação dos jesuítas na Inquisição. Ele deixou claro que os inacianos não eram chamados pelo Tribunal para consultar, mas para serem deputados do Santo Ofício, e como tal auxiliavam nos processos e davam seu parecer nas sentenças.

O provincial Alexandre Valignano disse ainda que não convinha à Companhia de Jesus parar de prestar esses serviços ao Tribunal. Isso não devia ocorrer porque - mesmo que a Ordem quisesse - a Inquisição encerraria suas atividades. Além disso, o rei obrigaria os jesuítas a continuarem trabalhando para o Santo Ofício.

A Inquisição de Goa, dizia Alexandre Valignano, sempre funcionou com a participação imprescindível dos inacianos. O padre Everardo Mercuriano, continuava o Provincial, jamais impediu que a Província de Goa participasse do Santo Oficio instalado naquela cidade. Seria impossível, caso os jesuítas desejassem, se afastar da Inquisição goesa porque os inquisidores não permitiriam que isso ocorresse, finalizava Alexandre Valignano ${ }^{346}$.

Alexandre Valignano se posicionou de modo totalmente contrário à postura assumida por ele em 1576 em relação à participação da Província de Goa na Inquisição. O que mudou? Em 1576 ele era o visitador. Entretanto, em 1586 ele falava na condição de Provincial. A função era outra. Talvez os interesses também fossem outros. Conhecia melhor as engrenagens inquisitoriais, as vantagens e desvantagens de ser uma de suas peças chaves.

Para ele havia mais vantagens em participar do que não participar do Santo Ofício. É provável que não fossem poucas as vantagens auferidas pela Província.

\footnotetext{
346 “Não entendemos aqui bem o que V. P. aqui quer dizer, porque os que vão à Inquisição não são chamados para consultar, mas são deputados para aquela mesa de Inquisição, e como deputados assistem em fazer os processos (grifo nosso) e dão seu voto nas sentenças (grifo nosso) que contra os réus se dão. E aqui nisso creio que não convém escusar, nem o podemos escusar mesmo se quiséssemos, porque sem os nossos não se poderá valer o Inquisidor, e o Rei sem dúvida assim o mandará, e desta maneira se ocorreu sempre (grifo nosso). E o Padre Everardo achou também que se não podia escusar, e que não havia para que se fazer difíceis nisto, pois contra a vontade dos inquisidores, mesmo se quiséssemos, no o poderíamos escusar.”
} 
Talvez por isso Alexandre Valignano não relutou em mudar de opinião e tenha omitido o fato de que o Vigário Geral Francisco de Borja proibiu a Província de Goa de participar do Santo Ofício ${ }^{347}$.

Sua carta contém um dado novo, o qual revela que os jesuítas foram, na prática, inquisidores do Tribunal do Santo Ofício de Goa: os inacianos eram deputados da Inquisição que “asisten en hazer los processos”. Ou seja, participavam dos processos inquisitoriais. Outra informação esclarecedora: os jesuítas não apenas assinavam as sentenças, eles votavam, quer dizer, podiam ou não concordar com elas.

A resposta do Vigário Geral foi taxativa. Mandou Alexandre Valignano escrever uma instrução para o novo Provincial de Goa, padre Pedro Martins, ordenando-lhe que proibisse os jesuítas de assistirem "aos atos da Inquisição como inquisidores ou agentes ou comissários do Santo Ofício, ainda que nestas partes se concede que sejam os nossos consultores do mesmo Santo Ofício, sendo avisados que não se metam em mais do que convém e se lhe dá licença”348. Ou seja, estava renovada a proibição de assistirem aos processos, votarem e assinarem as sentenças.

É provável que esta renovação tenha sido possível graças ao respaldo da bula Satis superque. Apesar do apoio do papa, Cláudio Acquaviva tinha um grave problema para resolver. Sua insistência em afastar os jesuítas do Tribunal do Santo Ofício de Goa agravava ainda mais as relações com o inquisidor Geral da Espanha, Gaspar de Quiroga y Vela, o qual, como já foi visto, era contrário ao afastamento.

É muito possível que a instrução escrita pelo visitador Alexandre Valignano atendendo à solicitação do Vigário Geral Cláudio Acquaviva, não tenha sido posta em prática. Porque cinco anos depois de escrita a instrução supracitada, ou seja, mais especificamente em junho de 1593, uma carta do jesuíta Manuel Dias para o

Trecho da carta de Alexandre Valignano, Provincial, para o Geral Cláudio Acquaviva. Cochim, 10. 12. 1586. In Documenta Indica XIV. Op. cit., pp. 438-39.

${ }^{347}$ Em 1587 Alexandre não era mais o Provincial de Goa. Naquele ano voltou a ser visitador.

348 "Sumário de Algumas Coisas que Pertencem ao Governo da Província da Índia para Instrução do P. Provincial, Feito pelo $P^{e}$. Alexandre Valignano, Visitador, por Ordem do N. Padre Geral, em Abril do Ano 
Vigário Geral Cláudio Acquaviva relatou a presença de dois inacianos - Jerônimo Xavier e Cristóvão de Castro - exercendo a função de deputados do Santo Ofício: "E o Inquisidor (Jerônimo Xavier) falando depois com um nosso, lhe disse tivera aquele converso na mesa muitos de toda sorte que o favoreceram; e o Padre entendeu aludia (sic) ao Prepósito da casa (Jerônimo Xavier) e outro Padre que eram deputados (Cristóvão de Castro)”349.

\section{OS CASOS DOS CRISTÃOS NOVOS GOMES VAZ E DUARTE DE SANDE}

Na mesma correspondência o Manuel Dias S. J. comunicou ao Geral - ou melhor, denunciou - que o padre cristão novo Gomes Vaz e outros professos, acolheram na casa professa um converso que acabava de sair do cárcere do Santo Ofício. No dia seguinte Gomes Vaz S. J. celebrou uma missa para o mesmo.

A intenção do cristão novo Gomes Vaz, dizia Manuel Dias, era ganhar esmolas do converso. Atitude considerada imoral por Manuel Dias.

É possível que tenha havido interesse financeiro por parte do cristão novo Gomes Vaz. Mas, ao mesmo tempo, é provável que seu gesto tenha representado uma atitude desinteressada visando, exclusivamente, o acolhimento solidário de um converso que esteve encarcerado no Santo Ofício. Essa hipótese não foi considerada pelo jesuíta Manuel Dias. Talvez por ter ficado incomodado com a provável solidariedade entre dois cristãos novos, sendo que um deles utilizou a Companhia de Jesus para acolher um cristão novo recentemente condenado pela Inquisição.

Uma carta com conteúdo semelhante já havia sido escrita em maio do mesmo ano (1593) pelo próprio padre, a qual também foi enviada para o Vigário Geral. Manuel Dias S. J. considerou que o acolhimento dado pelos jesuítas da casa professa ao converso que acabava de sair do cárcere do Santo Ofício e a missa celebrada para

88, e Tirado das Cartas e Ordens que Mandaram os Mesmos Gerais.” “Das Coisas que Pertencem ao P . Provincial e Suas Faculdades.” In Documenta Indica XIV. Op. cit., pp. 849-50. 
ele pelo cristão novo Gomes Vaz ia "contra a liberdade religiosa e crédito da Companhia” e que “embora cada uma por si não monta muito, umas com outras diminuem nosso bom nome e aumentam o conceito que têm os homens que somos cobiçosos ${ }^{350}$. Ou seja, caso os jesuítas continuassem demonstrando solidariedade com os cristãos novos que haviam sido condenados pela Inquisição, estariam comprometendo a reputação da Companhia de Jesus.

A argumentação do padre Manuel Dias revelou um paradoxo. Ao mesmo tempo em que disse que a Ordem tinha "bom nome" - o qual seria diminuído caso a casa professa continuasse acolhendo quem tinha sido condenado pelo Santo Ofício da Inquisição - reconheceu que a população consideravam os jesuítas cobiçosos. Talvez essa inconsistência lógica tenha decorrido do desejo irrefletido de reprovar os possíveis laços de solidariedade entre alguns jesuítas, notadamente cristãos novos, com os conversos que estiveram no cárcere da Inquisição goesa.

Em novembro o padre e consultor Francisco Vieira S. J. escreveu para o Vigário Geral confirmando a fama de que os jesuítas tinham de serem cobiçosos. Esta fama era decorrente da "sede e solicitude de granjear e adquirir da Casa Professa”. O que mais se destaca nesta função era o padre Gomez Vaz, chegando até ao "exagero". E, pelo fato de ser cristão novo conhecido, as suspeitas recaíam mais sobre ele, dizia Francisco Vieira. Desta fama decorreu seu afastamento da Casa Professa: "é cristão novo conhecido, que é causa de maior suspeita. Fora bom tirálo um tempo, que Deus não lhes há de faltar"351.

Em 1580, ocorreu um fato inusitado envolvendo a Companhia de Jesus e a Inquisição. O provincial Rui Vicente ${ }^{352}$ queria que o cristão novo Duarte de Sande,

\footnotetext{
${ }^{349}$ Trecho da Carta do padre Manuel Dias S. J. para o Vigário Geral Cláudio Acquaviva. Malaca, 27. 06. 1593. Documenta Indica XVI. Edited by Joseph Wicki S. J. and Jonh Gomes S. J. Roma, Institutum Historicum Societatis Iesu, 1984, doc. 31.

350 Trecho da carta do padre Manuel Dias para o Geral Cláudio Acquaviva. In Documenta Indica XVI. Op. cit., , p. 150.

351 Excerto da carta o padre Francisco Vieira para o Geral Clauido Acquaviva. Goa, 23. 11. 1593. In Documenta Indica XVI. Op. cit., p. 431.

${ }^{352}$ Rui Vicente S. J., antes de ingressar na Companhia de Jesus, foi capelão do cardeal D. Henrique. Embarcou para o Oriente junto com Alexandre Valignano (1574). Foi provincial entre 1574-83. Ver Franco,
} 
seu parente por parte de pai, que era cristão velho, pregasse nos autos-de-fé. Caso o inquisidor aceitasse Duarte de Sande, ele não seria considerado converso. Se tornaria um "homem de nome". Esse era o propósito de Rui Vicente, "limpar” o nome de Duarte de Sande. Lourenço Pinheiro, ciente da ascendência judaica de Duarte de Sande, aconselhou o provincial a não fazer o pedido ao inquisidor Bartolomeu da Fonseca.

O reitor do Colégio de Goa, padre N. Rodrigues, em nome do provincial - é o que afirmou Lourenço Pinheiro - insistiu com Bartolomeu da Fonseca para que ele aceitasse o “fidalgo” Duarte de Sande como deputado da Inquisição. O inquisidor conforme a narrativa do padre Lourenço Pinheiro - também sabedor do sangue judeu que Duarte de Sande carregava nas veias, ficou escandalizado com o que ouviu e disse que se aceitasse o pedido estaria cometendo um pecado mortal. Quer dizer, para o inquisidor Bartolomeu da Fonseca, não era função do Tribunal do Santo Ofício "limpar o sangue” dos cristãos novos.

Lourenço Pinheiro S. J., ao expor seu ponto de vista ao Vigário Geral, Everardo Mercuriano, disse que a intenção do padre Rui Vicente era boa, que todos o entenderiam, mas ao mesmo tempo considerou que faltou cautela ao Provincial ${ }^{353}$. Por sua vez, o jesuíta Lourenço Pinheiro não pensava muito diferente do inquisidor Bartolomeu da Fonseca a respeito da função do Santo Ofício em relação à aceitação de cristãos novos no seu quadro de inquisidores.

Os laços familiares existentes entre o provincial Rui Vicente e Duarte de Sande motivaram o provincial a procurar uma forma para "limpar o sangue" do seu irmão por parte de pai. Participar da Inquisição seria o meio mais eficaz de “limpeza”.

Por outro lado, caso Duarte de Sande fosse aceito como deputado do Santo Ofício, ele teria que condenar os próprios cristãos novos. Neste caso, a regra foi:

António S. J. Ano Santo da Companhia de Jesus em Portugal. $1^{\text {a }}$ Edição. Porto, Biblioteca do “Apostolado da Imprensa”, s/d, pp. 283-84.

${ }^{353}$ Ver carta do Padre Lourenço Pinheiro para o Prepósito Geral Everardo Mercuriano. Goa, 28. 10. 1580. In Documenta Indica XII. Op. cit., p. 138. 
"salve-se quem puder". Quer dizer, para Duarte de Sande era mais importante “limpar seu próprio sangue” do que solidarizar-se com os demais cristãos novos.

O caso Duarte de Sande também demonstrou que a Província de Goa continuava disposta a "acudir à Inquisição, ao menos no momento de dar sentenças e outras questões graves”, como dizia o padre Francisco Dionísio S. J.

\section{OS CASOS DO PERU E DO BRASIL}

A questão da participação da Companhia de Jesus no Tribunal do Santo Ofício no Peru suscitou problemas semelhantes aos ocorridos em Goa. Por exemplo, em fevereiro de 1585 o padre Juan Sebastián S. J. escreveu para o Vigário Geral Cláudio Acquaviva posicionando-se contra a presença dos jesuítas na Inquisição. Apesar de ter elogiado o Tribunal, considerando-o uma instituição santa e necessária para o bem “desta república”, o jesuíta Juan Sebastián entendia que a Companhia não estava agindo em conformidade com a humildade que a Ordem professava, nem tampouco com o espírito das Constituições:

"O que a mim toca, como Superior desta casa e experimentado no que deste colégio se nos segue, é dar notícia a V. P. de que, embora este ofício e todos os que tocam a este Santo Tribunal é muito santo e nestas partes muito necessário à malitia (malícia?) delas e bem desta república, porém, como a humildade que a Companhia professa e o espírito de nossas Constituições que nos proíbe aceitar bispados, por aquelas mesmas razões, que em parte são mais urgentes para o caso, julgo não convir a nossa Companhia que se permita deixar ocupar em semelhante cargos e ofício nem em outros que tenham mando, autoridade nem jurisdição"354.

\footnotetext{
354 Trecho da carta do padre Juan Sebastián para o Vigário Geral Cláudio Acquaviva. Potosí, 06. 02. 1585. In Monumenta Peruana III. Op. cit. p. 549. Naquele ano eram comissário do Santo Ofício em Potosí os jesuítas Diego de Bracamonte e Ruiz de Portillo. Conforme nota 19 referente à carta de Juan Sebastíán S. J de 06. 02. 1585. Inclusive uma carta do Provincial Baltasar Piñas de janeiro de 1548 enviada para o Geral Cláudio
} 
Assim como, muito provavelmente, ocorreu na Inquisição de Goa após a aprovação do estatuto de limpeza de sangue da Companhia de Jesus (dezembro de 1593), os jesuítas continuarem servindo ao Santo Ofício da Inquisição do Peru ${ }^{355}$. Do mesmo modo, houve jesuítas que continuaram se opondo a estes ofícios, como foi o caso do provincial Rodrigo de Cabredo. Ele escreveu para o Geral Cláudio Acquaviva informando-lhe que a função de comissário do Santo Ofício exercida pelo reitor do Colégio de Potosí, Christóval de Ovando, dificultava o exercício do seu reitorado naquele colégio ${ }^{356}$.

Durante o século XVI houve na América Portuguesa uma visitação do Tribunal do Santo Ofício. A visita ocorreu entre 1591 e 1595, cujo visitador foi o licenciado Heitor Furtado de Mendonça. As relações entre os cristãos novos e velhos da Companhia de Jesus, até à data da visitação, devem ter sido relativamente harmoniosas. Isso é o que indicou a documentação consultada.

O Provincial Pero Rodrigues escreveu para o Assistente em 7 de agosto de 1592 dizendo-lhe que os cristãos novos eram conhecidos fora do Reino, principalmente onde existia o Tribunal do Santo Ofício, como naquele momento havia na Bahia. Ou seja, o padre Pero Rodrigues sugeriu que, apesar dos descendentes de judeus serem reconhecidos como tais nas colônias portuguesas, esta questão ganhava mais importância onde havia a presença da Inquisição. Portanto, para o Provincial, o problema do cristão novo interessava mais aos Tribunais

Acquaviva encontra-se a referência ao padre Diego de Bracamonte como comissário do Santo Ofício da Inquisição. In Monumenta Peruana III. Op. cit., p. 330

${ }^{355}$ Por exemplo, na carta do padre José de Arriaga para o Vigário Geral Cláudio Acquaviva datada em 06. 04. 1594, constata-se a participação, sem restrições, dos jesuítas no Tribunal: "Os senhores do Santo se servem muito da Companhia em suas coisas; dois dos Nossos são qualificadores e os chamam muitas vezes para negócios que se oferecem.” In Monumenta Peruana V. Por Antonio de Egaña S. I. Roma, Institutum Historicum Societatis Iesu, 1970, pp. 345-46. Ou ainda carta do Provincial Rodrigo de Cabrero escrita em Lima em 20. 04. 1600 e enviada para o Geral Cláudio Acquaviva: "Os senhores do Santo Ofício se servem dos Padres para suas qualificações.” In Monumenta Peruana VII. Por Antônio Egaña S. I. e Enrique Fernandes S. I. Roma, Institutum Historicum Societatis Iesu, 1981, p. 43.

${ }^{356}$ Ver carta do padre Rodrigo de Cabredo, Provincial, para o Geral Cláudio Acquaviva. Março de 1602. In Monumenta Peruana VII. Op. cit., p. 795. 
inquisitoriais instalados nos domínios portugueses do que às Províncias da Companhia neles presentes ${ }^{357}$.

Mais de vinte anos antes da visitação, em 13 de julho de 1577, o Vigário Geral Everardo Mercuriano escreveu para o Provincial José de Anchieta dizendo-lhe que, para evitar escândalo e correspondente desedificação da Companhia, não devia receber cristãos novos. Entretanto, não eram os jesuítas nem a população da América Portuguesa quem pensava assim, e sim os europeus: "entende-se cá que se desedifica a gente de que recebamos cristãos novos na Companhia; por isso não deverão admitir tal sorte de pessoas, nem ainda outras que possam escandalizar. Em 15 de janeiro de 1579 a mesma ordem foi confirmada ${ }^{358}$. A primeira ordem parece que não foi obedecida, já que foi necessário confirmá-la. Isso confirma, ao menos em parte, a tolerância relativamente maior existente na América Portuguesa dos cristãos velhos em relação aos novos.

\section{A MISTERIOSA MORTE DO CRISTÃO NOVO LEONARDO NUNES}

Entretanto, em 1554 ocorreu um fato intrigante com o cristão novo da Companhia de Jesus, padre Leonardo Nunes. Ele ingressou na Companhia de Jesus em 6 de fevereiro de 1548. No ano seguinte, 1549, encontrava-se entre os primeiros jesuítas vindos para a América Portuguesa, sob o comando do padre Manuel da Nóbrega. Ao chegar, foi logo enviado por Manuel da Nóbrega para São Vicente, onde fundou o Colégio da Vila. Foi o primeiro jesuíta que esteve em Piratininga. Conforme o historiador da Companhia de Jesus no Brasil, padre Serafim Leite,

\footnotetext{
${ }^{357}$ Carta de Pero Rodrigues, 07 de agosto de 1592. Bras. 15, 393v. Citada por Leite, Serafim S. I. História da Companhia de Jesus no Brasil. Tomo II (Século XVI - A Obra). Lisboa, Livraria Portugália, Rio de Janeiro, Civilização Brasileira, 1938, p. 443. Um exemplo de cristão novo citado pelo padre Pero Rodrigues foi o padre Tolosa. Ver carta do padre Pero Rodrigues para o Assistente. Pernambuco, 24. 03. 1596. Bras. 15, 418v. Citada por Leite, Serafim S. I. Idem, p. 443.

${ }^{358}$ Ver Leite, Serafim S. I. Op. cit., p. 443.
} 
Leonardo Nunes foi um “incansável e zeloso missionário”, além de ser cantor e músico $^{359}$.

Libertou muitos índios do cativeiro. Inclusive foi pioneiro na luta pela libertação dos Carijó que haviam sido aprisionados pelos portugueses. Além de libertar, impediu o apresamento dos gentios feitos pelos cristãos portugueses e desfez concubinatos. Recebeu dos indígenas o cognome de "o padre que voa", graças ao seu dinamismo e entusiasmo pelo trabalho missionário ${ }^{360}$.

O próprio padre Leonardo Nunes relatou a vitória sobre o cativeiro injusto dos nativos realizado pelos cristãos: "esta terra entre outros males havia um nos cristãos muito arraigado e mal de erradicar por suas concupiscências e interesses, o qual era ter muitos índios injustamente cativos, porque os iam saltear outras terras e com manhas e enganos os cativavam,361. Ele também narrou as consequências da sua luta contra o concubinato: "fui perseguido de alguns amancebados por querer apartá-los do pecado, e por trabalhar para que se emendassem e tornassem a Deus ${ }^{\text {"362 }}$. Os mamelucos resistiram com violência à doutrinação do padre Leonardo Nunes e dos jesuítas em geral. Aproximadamente um ano depois da viagem de Leonardo Nunes, o irmão José de Anchieta disse que os mamelucos

\footnotetext{
${ }^{359}$ Ver a respeito Serafim Leite S. I. Monumenta Brasiliae I (1538-53). Roma, Monumenta Historica Societatis Iesu, 1959, pp. $37-38$.

${ }^{360}$ Franco, Antonio S, J. Imagem da Virtude em o Noviciado da Companhia de Jesus no Real Collegio de Jesus de Coimbra, na qual se Comtem as Vidas, e Virtudes de muytos Religiozos, que nesta Santa Caza foraõ Noviços. Offerecida A' Senhora da Victoria, Padroeira do mesmo Noviciado, pelo P. Antonio Franco da Companhia de Jesus. Seguno Tomo. Coimbra, no Real Collegio das Artes da Companhia de Jesus, Anno 1719, pp. 194 - 98 e Tellez, Balthazar S. J. Chronica da Companhia de Iesu na Província de Portugal e do que Fizeram, nas Conquistas d'este Reyno, os Religiosos, que na mesma Província entraram, nos annos em que viveo S. Ignacio de Loyola nosso Fundador. Pelo P. M. Balthazar Tellez, da mesma Companhia, natural da cidade de Lisboa, e nella Lente de Prima de Theologia. Primeira Parte na Qual se Contem os Princípios d'esta Província. No Tempo em que a fundou e governou o P. M. Simam Rodrigues, Com sua santa vida e morte. Em Lisboa, Anno do Senhor MDCXXXXV, P. 477.

${ }^{361}$ Carta do P. Leonardo Nunes para os padres e irmãos de Coimbra, [São Vicente, novembro [?] de 1550]. Monumenta Historica Brasiliae I (1538-53). Op. cit., p. 202.

${ }^{362}$ Idem, ibidem.
} 
“(...) estão tão duros e cegos, que crescem cada vez mais no ódio vivo que nos têm. Não o podendo exercer contra nós por obras, aplicam-no à ruína dos Índios, de maneira que já destruíram completamente uma Aldeia, em que morava o padre Francisco Pires com o padre Vicente Rodrigues, incitando os Índios a matar os contrários e a comer a sua carne”363.

Em 1554 o padre Leonardo Nunes viajou para a Europa. Os historiadores da Companhia de Jesus têm vários motivos para a viagem. Alguns dizem que o padre Manuel da Nóbrega foi quem o enviou por ser missionário de sua inteira confiança. Outros afirmam que o Vigário Geral, Inácio de Loyola, o mandou chamar. E têm ainda aqueles que justificam a viagem porque, segundo o "nosso modo de proceder, era necessário dar conta a Santo Inácio das coisas do Brasil”. O irmão José de Anchieta escreveu no mesmo ano da viagem de Leonardo Nunes. Em sua missiva enviada para D. João III e Inácio de Loyola, ele disse que o padre Leonardo Nunes embarcou para a Europa a mando do padre Manuel da Nóbrega ${ }^{364}$.

O historiador da Companhia de Jesus Simão de Vasconcelos disse que o padre Leonardo Nunes foi o escolhido por Manuel da Nóbrega porque ele era "o mais prático de todo o Estado"365. Ao dizer o "mais prático" o padre Simão de Vasconcelos talvez tenha reconhecido que Leonardo Nunes fosse o mais capacitado entre os jesuítas da Província para efetuar aquela tarefa.

\footnotetext{
${ }^{363}$ Carta do irmão José de Anchieta para o padre Geral Inácio de Loyola. São Vicente, fim de março de 1555. Monumenta Brasiliai II (1553 - 58). Por Serafim Leite S. I. Roma, Monumenta Historica Societatis Iesu, 1957, pp. $194-95$.

${ }^{364}$ Carta Quadrimestre de Maio a Setembro de 1554, de Piratininga. In Cartas, Informações, Fragmentos Históricos e Sermões do P. Joseph de Anchieta, S. J. (1554- 94). Rio de Janeiro, Civilização Brasileira, 1933. Sobre os motivos da viagem de Leonardo Nunes ver ainda: Tellez, Balthazar S. J. Op. cit., p. 478; Franco, Antonio S, J. Op. cit., p. 199; Vasconcellos, Simão de. Chronica da Companhia de Jesu do Estado do Brasil e do que Obraram seus Filhos N'Esta Parte do Novo Mundo. Em que se Trata da Entrada da Companhia de Jesu nas Partes do Brasil, dos Fundamentos que N'Ellas Lançaram e Continuaram seus Religiosos, e Algumas Noticias Antecedentes, Curiosas e Necessárias das Cousas D’Aquelle Estado pelo Padre Simão Rodrigues da Mesma Companhia. Tomo Primeiro (e Único). Segunda Edição Correcta e Augmentada. Vol. I Lisboa, em Casa do Editor A. J. Fernandes Lopes, MDCCCLXV, pp. 95-96; Monumenta Brasiliai II (1553 - 58). Por Serafim Leite S. I. Roma, Monumenta Historica Societatis Iesu,_1957, p. 38 e Sommervogel, Carlos, S. J. Bibliothèque de la Compagnie de Jésus. Bibliographie, tome V. Bruxelles, Oscar Schepens, Paris, Alphonse Picard, MDCCCXCIV, p. 1883.

${ }^{365}$ Vasconcellos, Simão de, S. J. Op. cit., p. 95.
} 
Existem algumas questões que não estão devidamente esclarecidas no que tange à viagem do padre Leonardo Nunes. O "modo de proceder" da Companhia de Jesus não era o de enviar seus padres à Europa para dar notícias a respeito das missões. Isto era feito através de cartas. Inclusive, houve uma sistematização das mesmas, tanto por tema como por período. Havia, por exemplo, cartas de edificação, informativas, quadrimestrais e anuais.

Em 15 de agosto de 1553 o padre Juan de Polanco escreveu para Manuel da Nóbrega em nome do Vigário Geral Inácio de Loyola, dizendo-lhe que era necessário ter um responsável pelo envio de todas as cartas e que, quem assumisse esta função, não permitisse o atraso da remessa das mesmas:

“ (...) para remediar isto, nosso Padre M. Ignacio ordena a V. R. e a quem quer que tivera cargo principal nesta colégio e nos outros da Índia, como Provincial ou substituto do Provincial, que ele tome cargo de enviar as cartas de todos, e lhes faça escrever alguns meses antes, porque não se falte”.

Na sequência da mesma carta, Juan de Polanco disse que o Vigário Geral precisava estar sempre informado para que pudesse assim suprir as necessidades das missões em tempo hábil: "Finalmente nosso Padre, como queria não faltar em prover do que convém, assim não queria que se faltasse de lá informações por mais insignificante que fosse ${ }^{\text {} 366}$.

Assumiu esta tarefa o irmão José de Anchieta. E no dia 17 de março de 1554 o Provincial de Portugal, Diego Mirão, estava enviando para Inácio de Loyola cópias das cartas que haviam chegado do Brasil contendo as informações da Província: “Com esta vão umas cópias de cartas do P. ${ }^{e}$ Nóbrega do Brasil com as

\footnotetext{
${ }^{366}$ Carta do Padre Juan de Polanco, por Comissão do P. Inácio de Loyola, para o padre Manuel da Nóbrega. Roma, 15 de agosto de 1553. In Monumenta Brasiliae I (1538-53). Op.cit., pp. 519-520.
} 
quais $V$. P. poderá ter alguma informação das coisas de lá e prover nelas como melhor parecerá no Senhor" 367 .

Quer dizer, as cartas eram o meio privilegiado dos jesuítas espalhados pelas missões ao redor do mundo se comunicarem. E elas funcionavam. Um mecanismo eficaz de informação, diga-se de passagem. Portanto, o motivo da viagem de Leonardo Nunes, levar informações, não se justifica, já que as cartas cumpriam muito bem sua função informativa.

Mesmo que este motivo fosse razoável - o que não era o caso - as missões tinham uma carência crônica de missionários. E a Província brasileira não era uma exceção. Várias foram as cartas enviadas para a Europa solicitando o envio de mais padres e irmãos. Entre 1549 e 1555 foram cinco cartas. E durante os anos de 1557 e 1558 mais seis.

Apesar da evidências acima demonstrarem que não havia motivos suficientes para a viagem do padre Leonardo Nunes, ele viajou. A Província perdia um dos seus poucos missionários, inclusive um dos mais capacitados.

Durante a viagem, 30 de junho de 1554, teria ocorrido um naufrágio, no qual o padre Leonardo Nunes havia falecido. Segundo consta na historiografia jesuíta, sua morte foi por todos sentida ${ }^{368}$.

Apesar da data da morte do padre Leonardo Nunes (30 de junho) ser consensual entre historiadores da Companhia de Jesus e de todos eles concordarem que ele faleceu no naufrágio, o padre Luís de Grã, contemporâneo de Leonardo Nunes, escreveu para o padre Diego Mirão em 24 de abril de 1555 informando-lhe sobre o boato dizendo que o navio no qual o padre Leonardo Nunes navegava havia sido capturado pelos franceses: “depois que sou no Brasil só um navio foi da Bahia para São Vicente em que foram os Irmãos com o padre Leonardo Nunes, a quem

\footnotetext{
${ }^{367}$ Carta o p. Diego Mirão ao P. Inácio de Loyola. Lisboa, 17 de março de 1554. In Monumenta Brasiliae I (1538-53). Op. cit., p. 50.

${ }^{368}$ Ver Monumenta Brasiliae I (1538-53). Idem, pp. 37e 38 e Vasconcellos, Simão de, S. J. Op. cit., pp. 95 e 96.
} 
Deus lá leve mais a salvamento do que se cá diz, porque a nova que o navio em que ia fora tomado dos franceses"369.

Ainda mais estranho e curioso foi o completo silêncio dos contemporâneos de Leonardo Nunes a respeito da sua morte. Afinal, ele era um jesuíta aguerrido, dedicado, competente e culto.

Existe uma possível explicação, mais sensata e coerente, para a viagem e a suposta morte do Padre Leonardo Nunes. Em 25 de maio de 1553 o padre Vicente Rodrigues escreveu para o jesuíta Luís Gonçalves da Câmara, residente em Lisboa, informando-lhe que o bispo D. Pedro Fernandes Sardinha vituperava os cristãos novos da casa, especialmente o padre Leonardo Nunes: "vitupera muitos cristãos

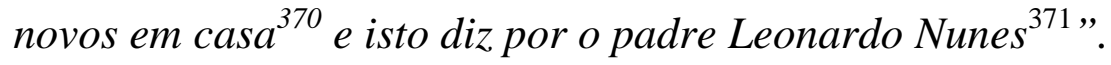

Já foi visto que o Padre Leonardo Nunes não aceitou os cativeiros "injustos" dos nativos, que inclusive foi pioneiro nesta luta e separou as concubinas dos portugueses. Por isso, ele foi um fator de desestabilização da sociedade colonial da época. Esta postura incomodou não somente os colonos, como também o bispo. Não é pouco provável que o padre Luís Gonçalves da Câmara tenha sido favorável à sua transferência para a Europa.

Como parcela importante dos colonos portugueses, o primeiro bispo do Brasil e os jesuítas cristãos velhos poderiam aceitar que um cristão novo se atrevesse a julgar e condenar a conduta dos colonizadores portugueses? Portanto, seria muito desconfortável para a Companhia de Jesus, mais especificamente a Província brasileira, manter um cristão novo tão “atrevido”. A sociedade colonial até que poderia ter suportado o que o Padre Leonardo Nunes havia feito, mas se ele não carregasse em suas veias o sangue judeu.

O padre Manuel da Nóbrega não encontrou outra saída senão mandá-lo de volta para o velho continente.

\footnotetext{
${ }^{369}$ Carta do Padre Luís de Grã [ao Padre Diego Mirão], Espírito Santo, 24 de abril de 1555. In Monumenta Brasiliai II (1553 - 58). Op. cit., p. 225.

${ }^{370}$ Colégio da Bahia. O padre Leonardo Nunes esteve na Bahia.
} 


\title{
CAPÍTULO VII. A COMPANHIA DE JESUS, OS CRISTÃOS NOVOS E A INQUISIÇÃO EM PORTUGAL
}

\author{
O PAPEL DE INÁCIO DE LOYOLA NA CONSOLIDAÇÃO DA \\ INQUISIÇÃO PORTUGUESA.
}

Em 29 de maio de 1542 o infante e inquisidor geral D. Henrique ${ }^{372}$ escreveu para o Vigário Geral da Companhia de Jesus, padre Inácio de Loyola. Na carta o inquisidor português solicitava que Inácio de Loyola ajudasse Baltasar de Faria ${ }^{373}$ a conseguir o apoio do papa no que se referia às "coisas da santa inquisição destes reinos e de nossa santa fé, 374 .

\footnotetext{
${ }^{371}$ Carta do Padre Vicente Rodrigues para o Padre Luís Gonçalves da Câmara. Bahia, 25 de maio de 1553. In Monumenta Brasiliae I (1538-53). Op. cit., p. 468.

${ }^{372}$ D. Henrique era filho de D. Manuel e D. Maria de Castela. Nasceu em Lisboa em 31. 01. 1512 e faleceu em Almeirim no dia 31. 01. 1580. Em 1534 tornou-se o arcebispo de Braga, portanto com 22 anos. No ano de 1539 recebeu das mãos do papa Paulo III o cargo de inquisidor de Portugal e suas conquistas. Posteriormente foi arcebispo de Évora - 1540 - e logo a seguir (1545) tornou-se cardeal. Em 1564 sucedeu o arcebispo de Lisboa. Entre 1562 e 1568 foi o regente português e em 28. 08. 1578 subiu ao trono onde permaneceu até sua morte ocorrida em 31. 01. 1580. Ver Enciclopédia Verbo Luso Brasileira. Op. cit., vol. 13, 2000, pp. 707-708. ${ }^{373}$ Baltasar de Faria tornou-se embaixador de Portugal pouco tempo depois da sua chegada a Roma, onde permaneceu durante nove anos.

${ }^{374}$ A bula de fundação da Inquisição de Portugal (1536) impôs restrições aos inquisidores e assegurou o prodomínio do poder do papa sobre o Tribunal. O pontífice nomeou três inquisidores enquando o rei nomenou apenas um, nos três primeiros anos de funcionamento do Tribunal as testemunhas deveriam declarar seus nomes, os bens dos condenados não poderiam ser confiscados durante dez anos, os bispos teriam os mesmos poderes que os inquisidores durante as inquirições das heresias e o núncio, em nome do papa, fiscalizaria o
} 
D. Henrique fez questão de justificar seu requerimento. Estava ciente das virtudes do Geral e do crédito e autoridade que ele possuía diante do papa Paulo III. E tinha certeza de que seria atendido por Inácio de Loyola porque, caso ele atendesse ao seu pedido estaria prestando grandes serviços a "nosso Senhor”. Inácio de Loyola teria mais dois motivos para ser solícito com D. Henrique; o inquisidor declarou sua "boa vontade e afeição" com a Companhia de Jesus e se predispôs a ajudá-la “com muito boa vontade”375.

Inácio de Loyola respondeu a carta do infante inquisidor em 16 de julho de $1542^{376}$. Disse que o pedido significava, ao mesmo tempo, uma graça divina e um grande favor que o príncipe lhe fazia: "muito especial graça e dom de nosso criador e senhor”, e "muito crescida e assinalada mercê que V. A. me quis fazer no Senhor nosso”377. Sentiu uma espécie de angústia, porque temia que suas forças físicas não fossem capazes de corresponder ao imenso desejo em servir o príncipe: "não pouca confusão de minha alma; sentindo nela os desejos muito subidos e as forças tão baixas e débeis para em tudo poder-me empregar em maior serviço de V. A.”378.

Assegurou que estaria ao inteiro dispor de Baltasar de Faria, como se ele fosse o próprio infante. Enfim, considerou o pedido feito pelo inquisidor geral como sendo "coisa tanto justa e santa". No fundo, dizia Inácio de Loyola, ao trabalhar para a inquisição portuguesa, seria ele mesmo quem estaria ganhando e fazendo um favor a si mesmo: "eu seja quem mais nisso ganhe e a quem maior favor se faz",379.

cuimprimento da bula, examinaria os processos e decidiria em última instância. Pela bula de 1539 a Inquisição de Portugal tinha uma série de restrições: priobia as testemunhas secretas, os acusados podiam apelar ao papa e os inquisidores não podiam ser pagos com o confisco dos prisioneiros.

${ }^{375}$ Ver carta do inquisidor de Portugal, D. Henrique enviada para Inácio de Loyola, vigário geral da Companhia de Jesus. In Monumenta Ignatiana. Série Prima. Epistolae et Instructiones. Tomus Primus (152448). Op. cit., p. 216.

${ }^{376}$ Ver a carta na íntegra em Monumenta Ignatiana. Idem, pp. 214-215.

${ }^{377}$ Idem, p. 214.

${ }^{378}$ Idem, ibidem.

${ }^{379}$ Monumenta Ignatiana. Idem, p. 214. 
Baltasar de Faria propôs, e Inácio de Loyola acatou, que o Geral da Companhia de Jesus procurasse o apoio dos cardeais mais envolvidos nas questões inquisitoriais antes do seu encontro com o papa ${ }^{380}$.

A conclusão da missiva de Inácio de Loyola foi otimista, apesar de prever alguma demora na obtenção dos resultados esperados pelo infante D. Henrique. Tinha a certeza de que tudo acabaria "em maior serviço de Deus N. S., e muito conforme à intenção e santo desejo de V. A.”381.

Passados dois meses após o envio da carta do inquisidor geral, mais especificamente em 28 de julho de 1542, Inácio de Loyola escreveu para o jesuíta Simão Rodrigues, ${ }^{382}$ que se encontrava em Portugal, acusando o recebimento da missiva do príncipe inquisidor. Dizia ainda que ficou à disposição Baltasar de Faria com toda vontade e que iria seguir as suas orientações. Quer dizer, Inácio de Loyola deixou evidente que aceitou o pedido do inquisidor geral de Portugal sem nenhuma restrição ${ }^{383}$.

Baltasar de Faria sugeriu que antes que Inácio de Loyola fosse conversar com o papa, atendendo assim ao pedido de D. Henrique, era necessário que os cardeais ficassem bem informados a respeito dos planos do inquisidor geral lusitano. O geral

\footnotetext{
${ }^{380}$ Ver a esse respeito Monumenta Ignatiana. Idem, p. 215. Ver também Novalin, José Luís Gonzales. La Inquisición y la Compañía de Jesús. In Antológica Annua, n. ${ }^{\circ}$ 37. Roma, Instituto Español de Historia Eclesiástica, 1990, p. 24.

${ }^{381}$ Monumenta Ignatiana. Série Prima. Epistolae et Instructiones. Tomus Primus (1524-48). Op. cit., P. 215.

${ }^{382}$ Ver Monumenta Ignatiana. Idem, pp. 216-225.

${ }^{383}$ Giuseppe Marcocci afirmou que o inquisidor geral de Portugal, infante D. Henrique, tinha reservas com a Companhia de Jesus. Um dos motivos seria a admissão de cristãos novos efetuada pela Ordem. O que vimos nas correspondências aqui analisadas foi a demonstração de amizade e de colaboração entre a Companhia, mais especificamente Inácio de Loyola, e o inquisidor D. Henrique. O jesuíta Leão Henrique (Vice-Provincial em 1565 e provincial entre 1566-70) foi confessor do inquisidor geral de Portugal, cardeal D. Henrique e auxiliar direto do infante nos assuntos concernentes à Inquisição. Inclusive foi membro do Conselho Geral do Tribunal do Santo Ofício de Portugal. Entretanto, essa aproximação entre D. Henrique e a Companhia de Jesus não impediu que o inquisidor geral de Portugal escrevesse para o papa Gregório III pedindo-lhe que não permitisse que a Congregação Geral (III, realizada entre 12. 04 a 16. 06 de 1573) elegesse para Geral nenhum cristão novo nem quem fosse simpatizante dos conversos; que proibisse o ingresso dos mesmos na Ordem e que impedisse que ingressassem na Companhia. Ver Marcocci, Giuseppe. Inquisição, Jesuítas e Cristãos novos em Portugal no Século XVI. Op. cit., pp. 253-54, 282-83 e 286. Esta questão será retomada logo a seguir.
} 
da Companhia de Jesus acatou, "satisfazendo a Deus Nosso Senhor”, o parecer do representante do príncipe inquisidor em Roma ${ }^{384}$.

Até à data em que a carta foi escrita - 28 de julho de 1542 - Inácio de Loyola já havia conversado uma vez com o cardeal de Santa Cruz, e duas com o cardeal Creçencio. Ambos disseram que o papa Paulo III estava ao lado do infante e do rei $^{385}$, ou seja, apoiava a consolidação da inquisição portuguesa nos moldes da espanhola.

Inácio de Loyola julgou que o pedido do infante era totalmente justo e esperava em Deus que tudo se realizaria “em boa e santa conclusão”386. A única ressalva que fez foi a possível demora até chegar aos resultados esperados. Isso porque havia muita querela entre as partes envolvidas, ambas apresentando sempre novas provas. Além de estar dependendo dos resultados obtidos pelo núncio, que foi enviado a Portugal para tratar do mesmo assunto, quer dizer, da Inquisição portuguesa.

Em Roma, dizia Inácio de Loyola, havia ocorrido um fato novo e bom para o “maior serviço de Deus”. Em função da grande necessidade existente na Itália, o papa Paulo III havia escolhido seis cardeais para atuarem como inquisidores a fim de "corrigir os muitos erros que por estas partes andam”. Além de ter reconhecido a necessidade do estabelecimento da Inquisição em Roma, Inácio de Loyola foi um grande incentivador da instalação daquele tribunal ${ }^{387}$.

\footnotetext{
${ }^{384}$ Ver Monumenta Ignatiana. Série Prima. Epistolae et Instructiones. Tomus Primus (1524-48). Op. cit., pp. 216-17.

${ }^{385}$ Monumenta Ignatiana. Idem, p. 218

${ }^{386}$ Monumenta Ignatiana. Série Prima. Epistolae et Instructiones. Tomus Primus (1524-48). Op. cit., p. 218.

${ }^{387}$ Trata-se, na realidade, da criação do Tribunal do Santo Ofício em Roma ocorrida em 1542; que contou não apenas com a anuência, mas com a colaboração de Inácio de Loyola: "Como quer que seja, eu em tudo espero que as coisas ocorram conforme ao maior serviço de Deus N. S., e como lá o desejais, e máximo (sic) que o negócio há vindo a bom tempo; porque, o que nunca se a feito nestas partes, parece que Deus N. S. tem dado princípio, devido à muita necessidade que existe por aqui, sobre muitos erros que por estas partes andam, a saber: como em Parma um predicador houvesse tido muitos erros, e o povo ficasse muito alvoroçado, como de Santa Cruz, que lá vai, podereis entender, eu insistindo muito e muitas vezes ao Cardeal de Burgos e ao Cardeal Tiatino, os quais tinham comissão do papa para entender sobre isso (grifo nosso), e acontecendo outros novos erros em Luca, eles falando ao papa diversas vezes, S. S. escolheu seis cardeais para que aqui em Roma formasse um corpo à maneira de Inquisição, para que possam prover por uma partes e por outras da Itália sobre os tais erros, possam prover em tudo (grifo nosso). Os cardeais são: Burgos, S. Clemente, $S$. Sixto, Tiatino, o que era mestre do sacro palácio, S. Marcelo, Guidachón e Parisiis. " Carta de Inácio de
} 
Entretanto, isso não era suficiente para Roma dar uma resposta definitiva às pretensões do inquisidor português. A Santa Sé queria saber o que estava ocorrendo com os cristãos novos portugueses - caberia ao núncio informá-la a esse respeito ${ }^{388}$. Essa notícia, que deixou Inácio de Loyola apreensivo, lhe foi passada pelo cardeal de Santa Cruz, o qual estava disposto a ajudar Inácio de Loyola e Baltasar de Faria. Santa Crua foi um dos primeiros cardeais que apoiaram o inquisidor geral de Portugal.

Além das conversas que vinha mantendo com os cardeais, Inácio de Loyola procurou o apoio de D. Margarida de Áustria ${ }^{389}$. Ela se comprometeu, com “muita boa vontade", atender ao pedido do Geral da Companhia de Jesus. Disse que na primeira oportunidade que se encontrasse com o pontífice, o que ocorreria em breve, falaria com ele a respeito do tema abordado por Inácio de Loyola ${ }^{390}$.

O vigário geral da Companhia de Jesus expressou seu desejo de ver Simão Rodrigues colaborando com o trabalho do núncio, dedicando-se com "todo prazer $e$ serviço possível”. E chamou a atenção do jesuíta português para a importância do bom entendimento entre ambos: "e não duvideis que muito ou todo importa que haja boa relação sobre esta coisa de inquisição"391.

Loyola para Simão Rodrigues escrita em Roma no dia 28 de julho de 1542. In Monumenta Ignatiana. Epistolae et Instructiones. Tomus Primus. Op. cit., p. 219. Ver a esse respeito Azevedo, João Lúcio de. Op. cit., p. 105, Kayserling, Mayer. Op. cit., p. 197 e Herculano, Alexandre. História da Origem e Estabelecimento da Inquisição em Portugal. Tomo III, $13^{\text {a }}$ edição, Amadora, Livraria Bertrand, s/d, p. 82. Os três confirmam a participação de Inácio de Loyola no estabelecimento da Inquisição em Roma. Ver ainda Novalin, José Luís Gonzales. Op. cit., p. 22.

${ }^{388}$ Inácio de Loyola escreveu para o núncio no mesmo dia em que compôs a carta enviada para Simão Rodrigues.

${ }^{389}$ Margarida de Áustria, filha de Carlos V, duquesa de Parma, futura governadora dos Países Baixos (155967), era grande protetora da Companhia de Jesus, muito próxima do papa Paulo III e esposa de Otávio Farnésio, sobrinho do pontífice. Ver a esse respeito Rodrigues, Francisco. Op. cit., p. 599.

${ }^{390}$ Ver Monumenta Ignatiana. Epistolae et Instructiones. Tomus Primus. Op. cit., p. 219

${ }^{391}$ Monumenta Ignatiana. Idem, p. 220. Em janeiro de 1543 o padre Simão Rodrigues escreveu para o geral Inácio de Loyola dizendo o seguinte: "eu não hei de deixar de fazer o que pensarei ser glória de meu Deus." Está evidente a autonomia que Simão Rodrigues demonstrou neste fragmento. Ver P. Simonis Rodericii Monumenta. In Epistolae PP. Paschasii Broëti, Claudii Jaji, Joannis Codurii et Simonis Rodericii. Societatis Jesu. Matriti, 1903, p. 532. Conforme aponta uma carta de Simão Rodrigues enviada para Inácio de Loyola em março de 1546, o geral voltou a solicitar que Simão Rodrigues apoiasse o núncio no que se referia à Inquisição. Simão Rodrigues recusou o pedido do geral: "Do que me escreves do núncio, os negócios vão de maneira, que creio é melhor estar eu de fora que meter a mão entre duas pedras; todavia eu secretamente faço o que posso para maior serviço de Cristo.” P. Simonis Rodericii Monumenta. Idem, p. 542. 
Antes de 28 de julho de 1542 Inácio de Loyola já havia conversado com o papa Paulo III. Ele fez uma rápida, mas esclarecedora narrativa da conversa. Esteve por muito tempo a sós com o Sumo Pontífice "informando-lhe sobre os grandíssimos erros e grandíssimas necessidades dos novos cristãos”392. Ele assegurou ao padre Simão Rodrigues que insistiu e utilizou as melhores razões de que era capaz de lançar mão em nome de Deus para conseguir o apoio do sumo pontífice à causa da Inquisição portuguesa ${ }^{393}$.

O encontro foi proveitoso. O vigário geral da Companhia de Jesus constatou, pessoalmente, que "A mente de S. S. está bem disposta, e desejosa de favorecer esta coisa da santa inquisição"394. Porém, o apoio do pontífice não era incondicional. Ele fazia questão de ouvir as partes envolvidas, pois era "pai de todos”. Mas Inácio de Loyola percebeu que a cautela do papa não representava uma ameaça séria aos propósitos de D. Henrique: "não sendo vontade que não se mude”.

Ao mesmo tempo em que Inácio de Loyola desempenhava a tarefa de conversar com os cardeais e o papa, Baltasar de Faria começava a "declarar $e$ descobri coisas, e bem descobrir". O geral da Companhia dava muitas graças a “Deus Nosso Senhor por isso”. Ou seja, segundo o relato de Inácio de Loyola, Baltasar de Faria estava cumprindo bem a sua tarefa.

Quanto ao empenho e dedicação do Vigário Geral, ele mesmo falou a respeito: "Eu de minha parte, no pouco que puder no Senhor nosso, fique certo, que até tirar sangue dos meus peitos, eu não faltarei ${ }^{395}$. Logo a seguir o próprio Inácio de Loyola se encarregou de esclarecer o motivo para tanto empenho: "um príncipe que tanto favorável e senhor nos é a todos no Senhor nosso"396.

Em 17 de agosto de 1542, Inácio de Loyola voltou a escrever para o padre Simão Rodrigues tratando do mesmo assunto, quer dizer, da Inquisição

\footnotetext{
392 Monumenta Ignatiana. Idem, p. 221. Sobre os erros dos cristãos novos, Inácio de Loyola disse que recebeu informações do próprio Simão Rodrigues. Ver Monumenta Ignatiana. Idem, p. 221.

${ }^{393}$ Ver a esse respeito Monumenta Ignatiana. Idem, p. 221

${ }^{394}$ Monumenta Ignatiana. Monumenta Ignatiana. Epistolae et Instructiones. Tomus Primus. Op. cit., p. p. 221.

395 Monumenta Ignatiana. Idem, p. 222.

${ }^{396}$ Monumenta Ignatiana. Idem, ibidem.
} 
portuguesa $^{397}$. Disse-lhe que o cardeal Creçencio, outro aliado à causa abraçada por Inácio de Loyola, confirmou o que ele, Inácio de Loyola, já havia percebido anteriormente: o apoio do papa Paulo III às demandas da Inquisição portuguesa formuladas pelo inquisidor geral e o seu desejo de que as providências neste sentido tivessem continuidade. Entretanto, o cardeal observou, como Inácio de Loyola, a mesma cautela do papa: o pontífice fazia questão de ouvir "todas as partes" envolvidas por ser "pai de todos". O cardeal Creçencio, continuou Loyola, também lhe informou que os cardeais estavam solidários com D. Henrique e dispostos a ajudá-lo.

Parece que houve um acordo geral para que as partes envolvidas na questão da Inquisição de Portugal, cristãos novos, o núncio e o inquisidor geral, resolvessem as querelas em Portugal. O bispo de Bérgamo ficou encarregado de informar à Santa Sé o que estava acontecendo nas terras lusas. Estas medidas comprovavam, segundo Inácio de Loyola, a vontade de favorecer a "santa inquisição" e de "favorecer o rei" portugueses.

O Geral da Companhia de Jesus entendeu que o fortalecimento da Inquisição em Portugal fortaleceria o poder político do monarca. A unidade religiosa como um pré-reguisito para a unidade política ${ }^{398}$. Atendendo ao pedido do inquisidor geral, ele estaria beneficiando, mesmo que indiretamente, ao monarca e assim retribuindo os favores dele recebidos pela Ordem por ele criada e dirigida ${ }^{399}$.

Uma das tarefas de Baltasar de Faria na Santa Sé foi a de revogar alguns privilégios que os cristãos novos tinham alcançado da Sé Apostólica. O cardeal Creçençio deixou claro para Inácio de Loyola que isso seria impossível de ser feito em Roma. Porque antes de revogar os privilégios em vigor era necessário provar que

\footnotetext{
${ }^{397}$ Ver carta na Monumenta Ignatiana. Idem, pp. 223-26.

398 João Lúcio de Azevedo escreveu a esse respeito: “A unidade da crença entre os súditos e a sua identidade com a do soberano era um princípio político, cuja necessidade ser revelou, na aparição do Estado moderno, como complemento indispensável da unidade do poder régio.” Azevedo, João Lúcio de. Op. cit., p. 105.

${ }^{399}$ O rei de Portugal, D. João III, já era um grande colaborador da Companhia de Jesus. Isso os jesuítas já tinham reconhecido desde 1541, como foi mencionado anteriormente.
} 
os meios utilizados pelos cristãos novos para conseguir aqueles privilégios eram falsos. E isso somente seria possível de fazer em Portugal, disse o Cardeal ${ }^{400}$.

Após uma conversa com Baltasar de Faria, na qual narrou o encontro mais recente que teve com o cardeal Creçençio, Inácio de Loyola propôs que o embaixador fosse pedir o apoio do vigário de Roma, Felipe Arquinto, amigo da Companhia e homem de grande influência nas questões inquisitoriais ${ }^{401}$.

O cristão novo Diego Ernández procurou Inácio de Loyola para conversar a respeito da inquisição e dos cristãos novos. O Geral o recebeu, porém evitou a continuidade do diálogo, dizendo que "naquela matéria" ambos estavam perdendo tempo ${ }^{402}$.

Inácio de Loyola justificou sua nova função de auxiliar do inquisidor geral de Portugal. Ele assumiu aquela missão pensando no "maior proveito de todas as almas convertidas”. Por isso, dizia o geral, não devia haver inibição alguma, já que os inquisidores cumpriam legitimamente suas funções de inquisidores e que todos deveriam ficar ainda mais à vontade porque os membros do Santo Ofício, ao invés de obterem proveito pessoal de seus trabalhos, tinham gastos: "os inquisidores são justamente inquisidores, e que fazem bem seu ofício, que não deveria haver inibição alguma, principalmente onde os inquisidores não obtêm proveito temporal de seus trabalhos, antes gastos”403. Loyola demonstrou que estava em paz com a sua consciência cristã.

O vigário geral da Companhia de Jesus considerou um grande erro a demanda dos cristãos novos; expressou o desejou de que eles não a alcançassem para assim facilitariam sua salvação. Portanto, para Inácio de Loyola, o fortalecimento da inquisição portuguesa era um meio de salvação dos cristãos novos:

\footnotetext{
${ }^{400}$ Ver Monumenta Ignatiana. Op. cit. p. 224.

${ }^{401}$ Ver Monumenta Ignatiana. Idem, ibidem.

${ }^{402}$ Monumenta Ignatiana. Epistolae et Instructiones. Tomus Primus. Op. cit., p. 224, pp. 225-26.

${ }^{403}$ Monumenta Ignatiana. Idem, p. 225.
} 
“ (...) me parece em Deus que a demanda destes novos cristãos (embora possam ter boa vontade) é muito errónea, e coisa que para suas almas não serve para melhor salvar-se; e assim penso, e não posso duvidar, que o Senhor nosso proverá como o desejais, e como melhor se salvem ${ }^{404}$.

Em 8 de março de 1543 Inácio de Loyola escreveu para o rei de Portugal, D. João III. Fez uma série de agradecimentos ao monarca pelos serviços prestados à Companhia de Jesus. Acreditava que Deus o recompensaria, tanto na terra quanto no céu, por sua infinita e suma bondade ${ }^{405}$.

Demonstrou humildade diante do monarca em relação aos serviços que vinha prestando à inquisição de Portugal e total disponibilidade ao rei. Nas palavras de Inácio de Loyola, ao servi-lo, a Companhia estava fazendo um grande benefício e um favor muito importante para ela mesma: "em tudo somos obrigadíssimos $a \mathrm{~V}$. A., se alguma coisa em seu devido serviço ocupar-nos pudéssemos, sendo a nós crescido benefício e favor muito marcante" ${ }^{306}$.

D. João III escreveu para Inácio de Loyola em 13 de agosto de 1545. Acusou o recebimento das duas cartas que o Geral the enviou em 18 de julho do mesmo ano, nas quais estão relatadas as negociações com o Papa sobre a inquisição de Portugal.

O monarca agradeceu a riqueza de detalhes das informações e supôs que o Pontífice estivesse consciente da importância do serviço que a Inquisição prestaria a “nosso Senhor”. Deixou claro que estava perdendo vassalos e fazendas, ou seja, que seu interesse era meramente religioso, portanto, “muito justo".

Reclamou contra o breve que suspendeu as sentenças finais do Tribunal do Santo Ofício ${ }^{407}$. Ao mesmo tempo informou ao Geral que enviou Simão de Veiga com a finalidade de pedir ao Papa a bula que consolidaria a inquisição em Portugal;

\footnotetext{
${ }^{404}$ Monumenta Ignatiana. Idem, p. 226.

405 Ver Monumenta Ignatiana. Idem, p. 244.

${ }^{406}$. Monumenta Ignatiana. Epistolae et Instructiones. Tomus Primus. Op. cit., Idem, p. 245.
} 
solicitou que Inácio de Loyola comunicasse à Sua Santidade o teor da carta e ajudasse Simão da Veiga em tudo que ele necessitasse ${ }^{408}$.

Inácio de Loyola foi encontrar-se com o Sumo Pontífice antes mesmo da chegada da correspondência do rei. Conversaram a respeito de uma missiva que o cardeal de Santa Flor, neto do papa Paulo III, tinha enviado para o monarca português, na qual havia o compromisso de que, caso o rei permitisse a entrada do núncio no seu reino, todos os pedidos do monarca concernentes à Inquisição portuguesa seriam concedidos:

“ (...) havendo-os escrito de algumas coisas passadas, depois da vinda do papa em Roma estive falando-lhe por mais de uma hora na câmara a sós com muita benignidade; e lendo-lhe [o] capítulo que o rei me escreve, a saber, como o cardeal de Santa Flor lhe havia escrito, que si S. A. tivesse por bem deixar entrar a seu núncio, concederia tudo o que S. A. lhe havia mandado pedir sobre o negócio da santa inquisição"409.

No final da conversa o pontífice Paulo III demonstrou certa disposição em fazer as concessões formuladas pelo monarca: "e mostrando em todas coisas muito amor e desejo para remediar, enquanto se pudesse justificar, me disse que onde o fundamento ou princípio era bom, que o fim seria assim mesmo bom” ${ }^{410}$.

\footnotetext{
${ }^{407}$ Este breve foi publicado em 22 de setembro de 1544. A publicação teria ocorrido porque a bula de 1539 não estaria sendo respeitada.

${ }^{408}$ Ver Monumenta Ignatiana. Idem, p. 324-25.

${ }^{409}$ Monumenta Ignatiana. Epistolae et Instructiones. Tomus Primus. Op. cit., p. 321.

${ }^{410}$ Ver, na íntegra, carta de Inácio de Loyola para Simão Rodrigues escrita em 04. 11. 1545. In Monumenta Ignatiana. Idem, pp. 321-22. Alexandre Herculano interpretou que o acordo acima foi proposto pelo pontífice. Se isso estivesse correto, não teria muito sentido Inácio de Loyola falar sobre algo sugerido pelo próprio papa e que contemplava os interesses do rei. A intenção do geral da Companhia de Jesus foi informar ao papa a proposta do cardeal Santa Flor, isso é o que se depreende da leitura do trecho da carta anteriormente citado. Como será visto logo a seguir, a decisão do papa estava dependendo da chagada da carta do núncio que se encontrava em Portugal. Alexandre Herculano disse ainda que Inácio de Loyola escreveu uma carta para o D. João III com o conteúdo semelhante à do cardeal Santa Flor (ou Santafiore): "Esta carta (do cardeal Santafiore) era acompanhada de outras de Simão da Veiga e de Ignacio de Loyola, o celebre fundador da Companhia de Jesus, particular afeiçoado de D. João III, em que se lhe assegura que, acedendo àquela condição (permissão do núncio entrar em Portugal) se chegariam a resolver de modo satisfatório as dificuldades ainda uma vez suscitadas ao definitivo estabelecimento da Inquisição.” Alexandre Herculano
} 
Ao encerrar a conversa com o Papa Inácio de Loyola esteve com o cardeal de Santa Flor. Disse-lhe que era necessário acelerar o processo de convencimento do Papa. O cardeal respondeu que faria tudo que lhe fosse possível para agilizar a decisão do pontífice ${ }^{411}$.

Após ter recebido a carta de D. João III o vigário geral da Companhia de Jesus foi até Monteflascón encontrar-se com o Sumo Pontífice em sinal de obediência ao monarca. Tratou da questão dos gastos e trabalhos do rei, da entrada do núncio no reino português, etc, visando convencer o pontífice a atender às demandas de D. João III.

O Papa mostrou-se receptivo, porém, antes de tomar qualquer decisão a respeito, considerou mais sensato aguardar a chegada das cartas que ele estava aguardando do núncio Montepulciano tratando dos cristãos novos e da Inquisição em Portugal ${ }^{412}$.

A carta do núncio havia chegado. Suplicava ao Papa que revogasse o breve que, praticamente, paralisou a Inquisição em Portugal. O pontífice estava disposto a atender a súplica do núncio.

Inácio de Loyola interferiu. Esclareceu ao Papa que a pretensão de D. João III era a publicação de uma bula concedendo à Inquisição portuguesa os mesmos direitos da Inquisição espanhola: "eu replicando que o que pretendia o rei era a bula, conforme o concedido primeiro, e assim como em Espanha se acostumava; a isto me disse, que também se daria todo presto, tornando a escrever ao núncio”,413.

\footnotetext{
não teve acesso a essa suposta carta de Inácio de Loyola. Ela apenas deduziu sua existência. É um despropósito. Apesar da influência de Inácio de Loyola na Santa Sé, ele não tinha poderes para escrever uma carta com este conteúdo, nem sequer semelhante. Ver Herculano, Alexandre. História da Origem e Estabelecimento da Inquisição em Portugal. Tomo III, $13^{a}$ edição. Op. cit., p.230.

${ }^{411}$ Carta de Inácio de Loyola para Simão Rodrigues escrita em 04. 11. 1545. Monumenta Ignatiana. Epistolae et Instructiones. Tomus Primus. Idem, p. 321.

${ }^{412}$ Ver a respeito carta de Inácio de Loyola enviada para Simão Rodrigues em 14. 12. 1545. In Monumenta Ignatiana. Epistolae et Instructiones. Tomus Primus. Op. cit., pp. 346-47.

${ }^{413}$ Excerto da carta de Inácio de Loyola para Simão Rodrigues escrita em 14. 12. 1545. In Monumenta Ignatiana. Idem, p. 348.
} 
O papa Paulo III assumiu o compromisso com Inácio de Loyola de que logo a bula seria publicada, a seguir escreveu para Montepulciano, muito provavelmente comunicando a sua decisão de publicar a bula.

O vigário geral da Companhia de Jesus tinha absoluta certeza de que o príncipe inquisidor conseguiria tudo que desejava. Ele não estava sozinho naquela luta, pois “todos desejavam” a mesma coisa, dizia Inácio de Loyola: “eu não duvido senão que sua alteza alcançará tudo o que deseja, e todos desejamos, para maior glória de Deus Nosso Senhor" ${ }^{\text {414 }}$.

Nesta mesma data em que escreveu para Simão Rodrigues, ou seja, em 14. 12. 1545, Inácio de Loyola havia escrito para o monarca português; o qual, em 16 de maio de 1546 acusou o recebimento da referida correspondência. Agradeceu as informações sobre o andamento das negociações com o pontífice a respeito dos seus interesses relativos ao Tribunal do Santo Ofício de Portugal e demonstrou estar grato pela aceitação do pedido feito ao Geral para Simão Rodrigues ser o tutor do príncipe João ${ }^{415}$.

Inácio de Loyola encontrou-se duas vezes com o secretário do papa Paulo III, Bernardino Mafeo, durante o mês de agosto de 1546. Conforme a avaliação do Vigário Geral estava havendo dificuldades acerca da Inquisição. Com o intuito de superar tais dificuldades Loyola se reuniu com o secretário do pontífice duas vezes entre 4 e 17 de agosto de 1546.

No segundo encontro, ocorrido em 17 de agosto de 1546, Bernardino Mafeo anunciou a Inácio de Loyola a última resolução a respeito da Inquisição em Portugal. Todos os que já estavam presos pelo Santo Ofício seriam tratados com "certa misericórdia" e os cristãos novos teriam quatro meses para decidirem se ficariam ou se partiriam de Portugal. Encerrado este prazo, ou seja, a partir de

\footnotetext{
${ }^{414}$ Excerto da carta de Inácio de Loyola para Simão Rodrigues escrita em 14. 12. 1545. Idem, ibidem.

${ }^{415}$ Ver carta de D. João III, Rei de Portugal enviada para Inácio de Loyola e escrita em 6 de maio de 1546. In Monumenta Ignatiana. Epistolae et Instructiones. Tomus Primus. Op. cit., p. 376.
} 
dezembro de 1546, "a santa inquisição fique em Portugal assim como está em Castela, ad perpetuam rei memoriam” ${ }^{416}$.

Se dependesse da dedicação dos partidários de D. João III em Roma a resolução anunciada por Bernardino Mafeo a Inácio de Loyola seria cumprida sem maiores problemas. Dizia Inácio de Loyola a esse respeito: "a estes senhores que têm tratado a matéria em lugar do rei, não há faltado más que morrer, havendo-se visto em tantos trabalhos e fadigas intrínseca e extrínseca sobre isso" ${ }^{417}$.

Um dos grandes responsáveis, senão o mais destacado, por este elevadíssimo nível de compromisso, por esse grau extremo de sacrifício à causa do monarca português e do infante D. Henrique, foi, sem dúvidas, o Vigário Geral da Companhia de Jesus e seu fundador, o padre Inácio de Loyola.

O resultado final do seu empenho e dedicação à consolidação da Inquisição portuguesa logo seria conhecido.

Ocorreu um atraso em relação à data prevista para a publicação da bula dezembro de 1546. Entretanto, sete meses mais tarde, ou seja, em 16 de julho de 1547 ela foi publicada sob o nome de Meditatio $\operatorname{cordis}^{418}$; aceita na íntegra por D. João III ${ }^{419}$.

Este foi o resultado de cinco anos da participação direta e decisiva do primeiro Vigário Geral da Companhia de Jesus e seu fundador, Inácio de Loyola: a consolidação do Tribunal do Santo Oficio em Portugal ${ }^{420}$.

Após a bula Meditatio cordis o sumo pontífice perdeu, praticamente, todos os poderes que possuía sobre a Inquisição portuguesa. O Tribunal do Santo Ofício luso conquistou a autonomia em relação à Santa Sé tão desejada pelo infante D. Henrique e por D. João III.

\footnotetext{
${ }^{416}$ Trecho da carta de Inácio de Loyola enviada para Simão Rodrigues, datada em 19 de agosto de 1546. Ver a carta na íntegra. In Monumenta Ignatiana. Idem, pp. 411-413.

${ }^{417}$ In Monumenta Ignatiana. Idem, p. 412.

${ }^{418}$ Cf. Corpo Diplomático VI, 166. Citado por Rodrigues, Francisco S. J. Op. cit., p. 601. A bula nomeou o infante D. Henrique inquisidor geral, anulou os poderes do núncio de examinar os processos e de decidir em última instância.

${ }^{419}$ Ver a esse respeito Rodrigues, Francisco S. J. Idem, p. 601.
} 
Enquanto o Papa Paulo III demonstrava certa relutância e cautela em atender aos interesses do infante inquisidor D. Henrique e de D. João III, Inácio de Loyola sempre foi solícito com ambos em seus propósitos de consolidar a inquisição lusitana e de controlá-la sem interferências de Roma.

O vigário geral da Companhia de Jesus não demonstrou, em nenhum instante, qualquer forma de escrúpulo ou dúvida em relação à legitimidade das demandas do infante D. Henrique e do rei D. João III em relação à Inquisição de Portugal. Muito pelo contrário, tentou e conseguiu persuadir vários cardeais, bispos e demais autoridades na Santa Sé. Exerceu grande influência, direta e indireta, na decisão do papa Paulo III em publicar a bula requerida pelos dois maiores representantes do projeto de autonomia da Inquisição portuguesa em relação à Santa Sé, D. Henrique e D. João III.

Tentou, e até certo ponto obteve, o apoio e a participação do jesuíta mais importante de Portugal na época e um dos fundadores da Companhia, o padre Simão Rodrigues.

Inácio de Loyola foi o grande articulador político do projeto inquisitorial elaborado por D. João III e pelo infante D. Henrique. Os contatos por ele estabelecidos, sua incansável persistência, seu prestígio e perspicácia política foram fatores decisivos para realizar, com sucesso, sua "missão".

O projeto inquisitorial elaborado pelo infante e pelo monarca ${ }^{421}$ foi assumido por Inácio de Loyola como se fosse ele próprio o idealizador ${ }^{422}$.

\footnotetext{
${ }^{420}$ A Inquisição portuguesa funcionou até 31 de março de 1821, quando foi extinta pelas "Cortes Gerais da Nação Portuguesa.”

${ }^{421}$ As referências a D. Henrique e a D. João III não implicam que somente eles eram os interessados em impedir a participação da Sé Apostólica da Inquisição de Portugal e dotá-la de poderes especiais. Eles representavam, politicamente, o pensamento intolerante existente em parcelas da sociedade portuguesa.

${ }^{422}$ Sobre a participação de Inácio de Loyola na consolidação da Inquisição em Portugal escreveu Francisco Rodrigues S. J.: "Tamanha era a sua solicitude,que,sendo outros os encarregados pelo rei de promover este negócio, ele parecia o mais empenhado em o concluir.” Rodrigues, Francisco. Op. cit., p. 599. Ver ainda Marcocci, Giuseppe. Op. cit., p. 256, onde o autor confirma a importância de Inácio de Loyola na obtenção da bula Meditatio cordis.
} 
Esta atitude do Geral teve duas causas principais. Foi uma forma da Companhia de Jesus retribuir os favores que vinha recebendo de D. João III e de D. Henrique. Também foi o meio pelo qual Inácio de Loyola "serviu a Deus”.

No plano espiritual, significou para Inácio de Loyola uma forma de facilitar a “salvação das almas" dos cristãos novos. No aspecto político, representou o estreitamento dos laços, que já eram bastante fortes, entre a Companhia de Jesus e a monarquia portuguesa, e a aproximação da Ordem com o Tribunal do Santo Ofício de Portugal.

Inácio de Loyola desempenhou um papel decisivo no processo de consolidação da Inquisição moderna portuguesa. Foi o incentivador da criação do Tribunal do Santo Ofício de Roma, o qual se propunha a ter jurisdição sobre toda Itália $^{423}$.

\footnotetext{
${ }^{423}$ Francisco Bethencourt disse que na bula de fundação da Inquisição romana, os inquisidores teriam autoridade sobre "toda a cristandade." Mas na prática, ele reconheceu que sua ação não se estendeu sobre a Península Ibérica e nem sequer centralizou toda a Península Itálica, como nos casos de Nápoles e Luca. Ver a Bethencourt, Francisco. História das Inquisições. Portugal, Espanha e Itália. Séculos XV-XIX. São Paulo, Companhia das Letras, 2000, pp. 27-30, especialmente páginas 27 e 28.
} 


\section{JOÃO III QUERIA UM JESUÍTA NA INQUISIÇÃO DE LISBOA}

Em 1555 o rei de Portugal, D. João III, solicitou ao provincial Diego Mirão um jesuíta para assumir o posto de inquisidor ${ }^{424}$. Conforme o padre Diego Mirão, o monarca queria apenas um inquisidor em Portugal, o qual seria portanto jesuíta ${ }^{425}$.

Inácio de Loyola respondeu a carta de Diego Mirão contendo a proposta de D. João III dizendo que obedecessem ao monarca em tudo. E que Diego Mirão assumisse, provisoriamente, o cargo de inquisidor enquanto escrevesse a Roma e aguardasse a resposta sobre a proposta do monarca, para somente depois tomar uma decisão definitiva ${ }^{426}$.

O padre Diego Mirão respondeu a carta do Geral, relatou a Loyola os apoios à sua indicação: o cardeal, o infante D. Luís, a rainha Catarina, Jerônimo Nadal S. J. e o próprio Francisco de Borja. Enquanto, dizia o jesuíta, D. João III deu sinais de que ficou satisfeito com a resposta dada por Inácio de Loyola.

O padre Diego Mirão, ao concordar que o pedido do monarca devia ser atendido, não se dispôs a assumir o cargo de inquisidor, em seu lugar indicou o padre Marco Jorge S. J., que lia casos em Évora, ao mesmo tempo em que demonstrou estar preocupado com a demora da resposta de Roma, já que, para ele, a solução do problema não era simples ${ }^{427}$.

A maioria dos professos da Companhia de Jesus foi favorável à escolha imediata de um jesuíta para exercer o cargo de inquisidor do Tribunal do Santo Ofício de Lisboa. A minoria alegou que, devido à grande importância da questão, seria mais adequado aguardar a resposta de Roma ${ }^{428}$.

Melchior Carneiro e Diogo Mirão estavam convencidos de que no futuro Inácio de Loyola iria agradecer a Deus pelos serviços que a Companhia prestaria ao

\footnotetext{
${ }^{424}$ Havia, além do inquisidor geral, dois inquisidores, sendo que um deles tinha falecido.

${ }^{425}$ Carta de Diego Mirão S. J. para o padre Francisco de Borja S. J, (sendo que um cópia foi enviada para Inácio de Loyola) escrita em Lisboa no dia 20 de abril de 1555. In Epistolae Mixtae, Tomo IV. Madrid, 1900, pp. 647-48.

${ }^{426}$ Idem, p. 649.

${ }^{427}$ Idem, ibidem.

${ }^{428}$ Idem, p. 650.
} 
conceder um dos seus padres para ser inquisidor, principalmente em Portugal, onde havia "tanta necessidade e falta de pessoas preparadas"

Porém, Diogo Mirão recomendava cautela. Seria conveniente consultar Roma e aguardar resposta antes de atender ao pedido de D. João III. Entretanto, somente aguardaria a resposta de Roma caso o monarca permitisse. Senão, seu pedido seria atendido imediatamente, independente do parecer de Roma ${ }^{430}$.

Os jesuítas que não concordavam que os inacianos se tornassem inquisidores argumentavam que eles se tornariam odiosos e temidos devido à autoridade e aos castigos do Santo Ofício, os quis não estavam conforme a "humilde maneira de proceder" da Ordem. Quanto aos cristãos novos, pouco proveito teriam com os jesuítas devido ao medo que estes lhes causariam. Evitariam se confessar com os jesuítas para não serem denunciados ao Santo Ofício da Inquisição ${ }^{431}$.

Diogo Mirão contestou todos os argumentos. A Companhia de Jesus só teria a ganhar tornando os jesuítas inquisidores. E quanto aos cristãos novos disse ele:

"Este género de gente de cristãos novos é muito odiosa, e o castigo deles é muito bem aceito no mundo, e com grande aplauso: o qual nos fará mais benévolo e seguros para o mundo, e dar-nos crédito, assim na vida como na doutrina, e seremos muito melhor recebidos com semelhante autoridade e crédito que têm de nós.”432.

Ou seja, as prisões e condenações dos cristãos novos, principais alvos da Inquisição portuguesa, seriam, entre outros, os meios pelos quais a Companhia de Jesus se promoveria.

\footnotetext{
${ }^{429}$ Epistolae Mixtae, Tomo IV. Op. cit., p. 650.

${ }^{430}$ Idem, ibidem.

${ }^{431}$ Idem, p. 651.

${ }^{432}$ Carta de Diego Mirão enviada para Francisco de Borja em 20. 04. 1555. Idem, ibidem.
} 


\section{PROPOSTAS DE DIOGO MIRÃO PARA A INQUISIÇÃO PORTUGUESA}

O Provincial da Companhia de Jesus em Portugal, Diogo Mirão, sugeriu uma série de reformas para a Inquisição portuguesa. Ao invés de ter apenas um inquisidor, como queria D. João III, ele propôs dois em função do trabalho causado pela existência de mais de duzentos prisioneiros nos cárceres do Santo Ofício. A Inquisição necessitava de uma casa própria e de familiares, como já havia na Inquisição de Castela. Ele sugeriu outras medidas. O inquisidor ou inquisidores jesuítas deveriam despedir quase todos os oficiais. Caberia também aos inquisidores inacianos contratar os novos oficiais, os quais deviam ter completa afinidade com a Companhia. As futuras contratações e dispensas dos oficiais ficariam a cargo dos jesuítas. Tanto o rei quanto o cardeal aprovariam estas medidas porque lhes pouparia trabalho. Era aconselhável que estas sugestões somente fossem postas em prática após a chegada da resposta de Roma, ponderou Diogo Mirão.

O Tribunal do Santo Ofício de Évora seria fechado e todas as atividades inquisitoriais se concentrariam em Lisboa. Isso seria possível de ser realizado graças à eficiência dos jesuítas, os únicos capazes, segundo diziam.

Finalmente, a proposta mais ousada do jesuíta Diogo Mirão: a Inquisição seria dirigida pelo provincial de Portugal, que na época era ele mesmo: "os que ali estiverem, hão de estar debaixo da ordem e obediência do provincial de Portugal.”"433. Qual seria a reação do cardeal? "Gostará disso”. Entretanto, como será visto, não foi exatamente isso o que aconteceu. O cardeal era também o inquisidor geral.

Em 14 de junho de 1555 Inácio de Loyola escreveu para Diogo Mirão. Ele foi extremamente cauteloso em relação à proposta de D. João III. A Companhia estaria disposta a servir ao monarca, contanto que não fosse algo que repugnasse a Ordem. Enfim, este era um assunto que devia ser cuidadosamente considerado; e devido à dignidade e à ocupação, e mais do que tudo, pelo poder de prender e de condenar,

\footnotetext{
${ }^{433}$ Epistolae Mixtae, Tomo IV. Op. cit, p. 649. As demais propostas encontram-se nas páginas 648-49.
} 
Inácio de Loyola temia que a nova função não estivesse em conformidade com o modo de proceder da Companhia de Jesus:

"No que toca ao cargo de inquisição, ver que S. A. se serviria disso, quando não repugnasse a nosso instituto, muito nos inclinaria a tomar tal assunto; porém a coisa é de muita consideração; e assim pela dignidade como pela ocupação, e mais que tudo pela autoridade e ofício de prender e condenar, temo muito que não seja coisa que se compadeça com nosso modo de proceder”.

Apesar das ressalvas, Inácio de Loyola se comprometeu a consultar os jesuítas que se encontravam em Roma para decidirem o que poderia ser feito para servir à S. A. e para alcançar a “maior glória de Deus N. S.”434.

Um dia após a escrita da carta, ou seja, em 15 de junho de 1555 os jesuítas já estavam reunidos para deliberar sobre a proposta de D. João III. Reuniram-se Diogo Lainez, Alfonso Salmerón, Nicolau Bobadilha, Dr. Olave, Dr. Madrid e Juan Polanco. Nesta mesma data Juan de Polanco escreveu para Diego Mirão informando-lhe que a comissão se inclinava por aceitar a proposta ${ }^{435}$.

\section{$\underline{\text { A DECISÃO DA COMPANHIA A RESPEITO DA PROPOSTA DO }}$}

\section{MONARCA}

No dia 20 de junho de 1555 Inácio de Loyola voltou a escrever para Diogo Mirão. A decisão estava tomada ${ }^{436}$. Era necessário obedecer ao monarca em tudo que lhe parecesse ser para a glória de Deus. Ao reconhecer que o cargo não

\footnotetext{
${ }^{434}$ Carta de Inácio de Loyola para Diogo Mirão. Roma, 14. 06. 1555. In Monumenta Ignatiana, Série $1^{\mathrm{a}}$, Tomo IX. Madrid, 1900, p. 163.

${ }^{435}$ Carta de Juan de Polanco para Diogo Mirão. Roma, 15. 06. 1555. In Monumenta Ignatiana, $1^{\text {a }}$ Série, Tomo IX. Idem, p. 215.

${ }^{436}$ Não houve unanimidade entre os consultados. O parecer de Diego Lainez foi contrário. Para ele as funções de inquisidor não eram compatíveis com o espírito de humildade ao qual a Companhia recorria para ajudar as
} 
repugnava à Companhia, esta demonstrava que pertencia à S. A. em “Nosso Senhor”. A nova função a ser assumida, além de contribuir com a pureza da religião no reino português, serviria ao rei. Portanto, não havia motivos para recusar a nova tarefa.

Entretanto, Inácio de Loyola fez algumas ressalvas. Caso o rei não tivesse nenhuma objeção, escrevesse para o Papa pedindo-lhe autorização para que os jesuítas aceitassem o cargo de inquisidores. A anuência do papal seria aconselhável, já que ele era o decano dos cardeais inquisidores, dizia Inácio de Loyola. O Geral da Companhia de Jesus também sugeriu que escrevesse para o cardeal Carpi, protetor da Ordem e agora decano dos inquisidores e outra para seu embaixador. Porém, se o monarca achar que não convém, que se fizesse o que S. A. mandasse para a glória divina.

Se D. João III não quisesse aguardar o consentimento do Papa, a Companhia se dispunha a emprestar um ou dois jesuítas até chegar a aprovação papal. Porém, que se fizesse o que mais agradasse ao monarca, concluía Inácio de Loyola.

\section{HENRIQUE ESCOLHEU UM DOMINICANO PARA INQUISIDOR}

A comunicação entre Inácio de Loyola e Diogo Mirão ficou suspensa até setembro de 1555. No dia cinco deste mês o padre Diogo Mirão escreveu para Inácio de Loyola. Na missiva informava-lhe que o cardeal "impediu” a indicação dos jesuítas para exercerem o cargo de inquisidores em Lisboa. Foi indicado o dominicano Fr. Jerônimo da Azambuja ${ }^{437}$, inquisidor em Évora desde 1552. Entretanto, D. Henrique escreveu ao infante pedindo que ele sugerisse ao monarca que a Companhia de Jesus assumisse a Inquisição de Coimbra. O rei gostou da

almas. O padre Diego Lainez era cristão novo. Ver a respeito da posição de Diego Lainez: Novalin, Jose Luis Gonzalez. Op. cit. p. 25, especialmente nota 54.

437 J. L. G. Novalin o nomeou Gerónimo de Oleastro. Novalin, José Luis Gonzales. Op. cit., p. 26. 
proposta, assim como o infante e a rainha. Foi uma solução divina, disse Diogo Mirão $^{438}$.

Ocorre que, apesar da Inquisição de Coimbra ter sido criada em 1541 mesmo ano da instalação do Tribunal em Lamego, Porto e Tomar -, apenas em Lisboa e Évora o Santo Ofício estava em funcionamento naquele ano $(1555)^{439}$. A Inquisição de Coimbra somente foi restabelecida em $1565^{440}$. O confisco dos bens dos cristãos novos estava suspenso, e continuaria assim por mais quatro anos ${ }^{441}$. O monarca pretendia reduzir as despesas com o Tribunal, como ficou claro quando propôs a presença de apenas um inquisidor em Lisboa. O infante D. Luis, que apoiava a proposta do monarca, acabava de falecer ${ }^{442}$. Portanto, o projeto do inquisidor geral era, naquele momento, praticamente inviável para a Companhia de Jesus $^{443}$.

José Luis Gonzalez Novalin assim considerou o desfecho da proposta do monarca: “ (...) felizmente o projeto do rei não pode levar-se a cabo, porque seu irmão D. Henrique nunca o havia compartilhado seriamente e se adiantou a nomear inquisidor de Lisboa ao dominicano Gerónimo de Oleastro, que até então havia sido inquisidor em Évora." ${ }^{444}$.

Se o inquisidor geral de Portugal, cardeal e infante D. Henrique, ficou sabendo das propostas do provincial Diego Mirão relativas à Inquisição portuguesa

\footnotetext{
${ }^{438}$ Ver Carta de Diogo Mirão para Inácio de Loyola. Lisboa, 05. 09. 1555. In Monumenta Ignatiana, Série $1^{\text {a }}$, Tomo XII. Madrid, 1911, p. 513.

${ }^{439}$ Ver carta de Diogo Mirão enviada para Francisco de Borja em 20 de abril de 1555. In Epistolae Mixtae IV. Op. cit, p. 649.

${ }^{440}$ Ver a respeito Bethencourt, Francisco. Op. cit., pp. 44 e 53.

${ }^{441}$ Conforme carta de Diogo Mirão enviada para Francisco de Borja em 20 de abril de 1555. In Epistolae Mixtae IV. Op. cit, p. 649. Segundo Francisco Bethencourt, o confisco somente foi implantado em Portugal em 1563, quando o D. Henrique assumiu a regência. Ver Bethencourt, Francisco. Op. cit., p. 45.

${ }^{442}$ Ver Novalin, José Luis Gonzales. Op. cit., p. 25, nota 54. O infante D. Luis, nas palavras do jesuíta Inácio de Azevedo, "não era mais que um irmão da Companhia no amor e na benevolência." Citado por Rodrigues, Francisco. Op. cit., t. I, vol. II, p. 609.

${ }^{443}$ Francisco Rodrigues atribuiu o motivo dos jesuítas não terem assumido a Inquisição de Coimbra porque os inquisidores não estariam sob o comando da Companhia de Jesus. È uma hipótese plausível. Porém, sem fundamento prático, factual. Ver Rodrigues, Francisco. Op. cit., t. I, vol. I, p. 697.

444 "Afortunadamente el proyecto del rey no pudo llevarse a cabo, porque su hermano don Enrique nunca lo había compartido en serio y se adelantó a nombrar inquisidor de Lisboa al dominico Gerónimo de Oleastro, que hasta entonces lo había sido de Evora.” Novalin, José Luis Gonzales. Op. cit., p. 26.
} 
- o que não é pouco provável - é evidente que ele não permitiria perder o controle do Tribunal, ou melhor, perder o cargo de inquisidor geral, pois na prática, era isso o que significava a proposta de Diego Mirão para o provincial da Companhia de Jesus dirigir a Inquisição em Portugal. O cardeal não gostou e não aceitou a sugestão de Diego Mirão, contrariando suas previsões de que o cardeal o apoiaria. Expectativas totalmente infundadas.

\section{SERVIÇOS PRESTADOS PELA COMPANHIA DE JESUS À INQUISIÇÃO}

\section{PORTUGUESA}

A Companhia de Jesus já estava trabalhando para a Inquisição portuguesa. Inclusive o monarca a remunerava pelos serviços prestados. O mesmo ocorreria com os inquisidores jesuítas, ou seja, seriam pagos pela Coroa: “A sustentação que terão os nossos, será com o rei passar cada ano um alvará, que lhes dá tanto de esmola aos Padres da Companhia que estão na inquisição."445.

Os serviços que a Companhia de Jesus vinha prestando ao Tribunal do Santo Ofício de Portugal até àquele momento, considerando o parecer do inquisidor de Évora, licenciado Pedro Álvares Paredes, eram de excelente qualidade: "São humildes, zelosos da salvação dos próximos; e para efetuar isto e estender a doutrina evangélica, não recusam trabalhos, antes com toda caridade, segundo o santo Evangelho" ${ }^{446}$. Os jesuítas também teriam recebido elogios semelhantes do inquisidor de Lisboa ${ }^{447}$.

Apesar de ter sido louvada por inquisidores e do apoio do infante D. Luis, a Companhia de Jesus não conseguiu dirigir a Inquisição em Portugal, como desejava Diogo Mirão e nem sequer conseguiu indicar um inquisidor para o Tribunal de Lisboa, como queria D. João III.

\footnotetext{
${ }^{445}$ Carta de Diogo Mirão para Francisco de Borja. Lisboa, 20. 04. 1555. In Epistolae Mixtae. Tomo IV. Op. cit., p. 649.

${ }^{446}$ Citado por Rodrigues, Francisco. Op. cit., T. I, Vol. II, p. 625.

${ }^{447}$ Ver Idem, ibidem.
} 
Um dos motivos, como já foi visto, foi a oposição do inquisidor geral D. Henrique. Outro, este não tão evidente, mas muito provável, foi a resistência dos dominicanos. Talvez não tenha sido por acaso a indicação de um dominicano para ocupar a vaga deixada pela morte do inquisidor de Lisboa. È provável que tenha ocorrido uma confluência de interesses entre os dominicanos e o inquisidor geral. Aos dominicanos caberia a prioridade em relação aos jesuítas. D. Henrique teria reconhecido esse direito porque eles, os dominicanos, não ameaçavam seu domínio sobre a Inquisição em Portugal.

A Companhia de Jesus perdeu uma oportunidade de ganhar ainda mais prestígio na sociedade portuguesa, como almejava Diogo Mirão, e deixou de ter mais uma fonte de renda. Isso ocorreu, muito provavelmente, porque nas questões referentes à Inquisição portuguesa os dominicanos demonstraram, naquele momento, que eram mais habilidosos politicamente, além de terem maior influência na corte portuguesa quando o tema era Inquisição.

Entretanto, a Companhia de Jesus não deixou de continuar prestando seus serviços ao Tribunal do Santo Ofício após 1555 em Portugal.

Desde 1553 os jesuítas da Província portuguesa confessavam os prisioneiros do Santo Ofício em Lisboa e Évora. Neste mesmo ano, no auto-de-fé realizado em Évora, o padre Manuel Fernandes S. J. "proferiu um comovente sermão”. Os jesuítas continuaram confessando os condenados e pregando em mais quatro autos-de-fé realizados em Lisboa e Évora entre 1553 e 1560, inclusive com a presença de Leão Henrique, provincial entre 1566-1570, e membro do Conselho do Santo Ofício a partir de 1571.

É muito provável que estas práticas inquisitoriais de confissões e sermões nos autos-de-fé não tenham sido interrompidas até $1593^{448}$.

Um jesuíta do colégio de Coimbra, provavelmente o reitor, ouviu a confissão de um prisioneiro em 01 de setembro de 1563. O confessor denunciou que o sogro e 
a sogra eram judaizantes. O jesuíta comunicou ao vigário da cidade, o qual mandou chamar o prisioneiro para depor diante dele. O vigário ficou muito agradecido pela atitude do jesuíta em nome da honra de Deus e zelo da fé ${ }^{449}$.

Em 4 de junho de 1570 o reitor do Colégio do Porto, padre Rui Vicente, publicou o édito da fé e aproveitou a oportunidade para pregar em louvor da fé católica $^{450}$. Rui Vicente, ao lado do também jesuíta Fernam Carvalho, fez sermões e confessou os prisioneiros enquanto durou a visitação do Santo Ofício na cidade do Porto ${ }^{451}$.

No ano seguinte, 1571, graças aos esforços do inquisidor geral de Portugal, infante D. Henrique, a Companhia de Jesus passou a ser representada no Conselho Geral da Inquisição $^{452}$. O primeiro jesuíta a ocupar o cargo foi Leão Henrique, na época confessor de D. Henrique. Permaneceu no Conselho até 1579, quando foi substituído por Jorge Serrão S. J., o qual permaneceu como deputado do Santo Ofício até - provavelmente - sua morte ocorrida em $1590^{453}$.

No segundo semestre de 1572 o padre Diogo Coelho, do Colégio de Bragança, prestou alguns serviços ao Tribunal do Santo Ofício de Coimbra. Entre outros serviços prestados, denunciou uma série de cristãos novos ${ }^{454}$.

Em agosto de 1579, muito provavelmente, os jesuítas Duarte de Meneses e Belchior Paulo, denunciaram um suposto cristão novo judaizante à Inquisição de Coimbra $^{455}$.

\footnotetext{
${ }^{448}$ Ver a esse respeito Rodrigues, Francisco. cit., t. I, vol. I, pp. 689-92. O historiador jesuíta considerou a participação da Província lusitana na Inquisição como gesto piedoso, visando a salvação das almas dos condenados pelo Tribunal. Ver ainda Novalin, José Luis Gonzales. Op. cit., p. 26.

${ }^{449}$ Ver carta de Pedro da Silva por comissão do reitor do Colégio de Coimbra. Coimbra, 01. 09. 1563, em ARSI, Lus. 52, fls. 29-32v, em particular fl. 30v. Citado por Marcocci, Giuseppe. Op. cit., pp. 308-309.

${ }^{450}$ Ver Rosário, António do. Visitação da Inquisição a Entre-Douro-e-Minho. Braga, Libraria Cruz, 1978, pp. 2 e 3. Citado por Marcocci, Giuseppe. Op. cit., pp- 280-81.

${ }^{451}$ Carta de João Peres ao padre geral Francisco de Borja. Porto, 03. 07. 1570. ARSI, Lus. 64, fls. 66-68v, em particular fl. 66. Citado por Marcocci, Giuseppe. Idem, p. 281.

${ }^{452}$ Conforme carta ânua de 1571 escrita pelo padre Luis Perpiñan por comissão do Provincial Jorge Serrão. Lisboa, 15. 01. 1572, em ANTT, Manuscritos da Livraria, 690, Cartas Anuais dos Jesuítas, 1571-1629, fl. 1v. Citada por Marcocci, Giuseppe. Idem, pp. 282-83.

${ }^{453}$ Ver a respeito Marcocci, Giuseppe. Idem, p. 323. Jorge Serrão foi reitor dos Colégios de Évora e Coimbra, prepósito da Casa de S. Roque, professor de teologia da Universidade de Évora e Provincial entre 1570-74. Ver a seu respeito, Rodrigues, Francisco. A Companhia de Jesus em Portugal e nas Missões. Esboço Histórico - Superiores- Colégios - 1540-1934. Op. cit., p. 20.
} 
Luís de Paiva denunciou, na confissão feita em 1588, ao padre Luís da Cruz, jesuíta do Colégio de Bragança, que sua cunhada judaizava. Luís da Cruz escreveu aos inquisidores de Coimbra relatando o ocorrido. O próprio jesuíta identificou a acusada como sendo Leonor de Valladolid ${ }^{456}$.

Por outro lado, um jesuíta de Coimbra teria absolvido um fiel que não fez a confissão anual (1564) obrigatória. Entretanto, os inquisidores de Coimbra não reconhecerem como válida a absolvição dada pelo inaciano ${ }^{457}$. Contudo, Em nenhum dos casos acima relatados os jesuítas absolveram os cristãos novos.

\section{JESUÍTAS PORTUGUESES NA III CONGREGAÇÃO GERAL}

Em 30 de setembro de 1572 morreu o terceiro Vigário Geral da Companhia de Jesus, Francisco de Borja. Entre outubro de 1572 e abril de 1573 assumiu o generalato da Ordem o cristão novo Juan Alfonso de Polanco, período no qual estavam ocorrendo os preparativos da terceira Congregação Geral, a qual elegeria o novo Geral ${ }^{458}$.

Um dos representantes da Província de Portugal na terceira Congregação foi o padre Leão Henriques ${ }^{459}$. Com ele foi enviada uma carta escrita pelo inquisidor geral de Portugal, infante D. Henrique, para o Papa Gregório XIII. Na missiva o inquisidor pedia que o Sumo Pontífice tomasse "as mais acertadas providências, para que nenhum cristão novo nem alguém que pareça favorecê-los, seja eleito Geral; e que não se recebam na Companhia homens dessa raça, nem sejam nela superiores”. Essas medidas, nas palavras do Cardeal, necessárias não somente para a

\footnotetext{
${ }^{454}$ Ver a respeito respeito Marcocci, Giuseppe. Idem, pp.301- 302.

${ }^{455}$ Carta de Duarte de Meneses e Belhior Paulo aos inquisidores de Coimbra, sem lugar nem data. Em ANTT, Inquisição de Coimbra, Livro 79, fls. Não numeradas. Citado por Marcocci, Giuseppe. Idem, pp. 303-304.

${ }^{456}$ Ver carta do padre Luís da Cruz aos inquisidores de Coimbra. Bragança, 18. 07. 1588. ANTT, Inquisição de Coimbra, maço 58, doc. 95. Citado por Marcocci, Giuseppe. Idem, pp. 317-18.

${ }^{457}$ Ver interrogatório do mestre João de Coimbra, de 08. 01. 1565. ANTT, Inquisição de Lisboa, processo 1609, fls. 23rv. Citado por Marcocci, Giuseppe. Op. cit., p. 308.

${ }^{458}$ Os Vigários Gerais eram eleitos, exclusivamente, pelas Congregações Gerais.

${ }^{459}$ Na realidade o padre Leão Henrique foi eleito para ser delegado da Congregação porque o Provincial Jorge Serrão havia adoecido. Conforme carta de D. Henrique para o Vigário Geral Juan Alfonso de Polanco. Évora, 22. 01.1573
} 
Companhia de Jesus, mas para todo o reino de Portugal, deviam ser tomadas o quanto antes, porque, dizia o inquisidor:

"Se não emprega o remédio a tempo, é de temer não venha a perigar e destruir-se essa Companhia. Porquanto, se principia a relaxar-se, o que é próprio dos cristãos novos, faltando-lhe a perfeição e integridade de vida que a deve animar (grifo nosso) sem demora cairá na sepultura”.

Em função de tamanho risco, concluiu o inquisidor: "Pelo que, a Vossa Santidade rogo encarecidamente e com a maior força da minha alma, que aplique o remédio a tamanho mal, porque nesta diligência prestará Vossa Santidade a Deus o maior obséquio, e a mim fará o mais estimado benefício".

Além da incumbência de entregar a carta ao Papa, Leão Henrique devia relatar ao Pontífice "tudo o que ele sabe, viu e experimentou desta nação de neófitos ou cristãos novos, além do que de mim recebeu"460.

A delegação portuguesa, constituída pelos padres Luís Gonçalves da Câmara, Miguel de Torres, Inácio Martins, além do próprio Leão Henriques, passou pela corte de Madrid onde obtiveram uma carta do rei Felipe II, na qual constava o apoio do monarca às pretensões de D. Henrique, pelo menos no que se refere à eleição de um cristão velho para o cargo de Vigário Geral da Companhia. É o que se deduz da carta do cardeal enviada para Felipe II dizendo que "tenho informação que o Geral da Companhia procede muito bem. E será o merecimento de V. Al. que tanto favoreceu esta eleição".

Após alguns dias da partida dos delegados da Província portuguesa, o rei D. Sebastião escreveu duas cartas. Uma para Leão Henriques e outra para o Papa Gregório XIII. Na correspondência enviada ao Pontífice dizia o monarca:

\footnotetext{
${ }^{460}$ Ver a carta do Cardeal em Marcocci, Giuseppe. Op. cit., pp. 286-87 e em Rodrigues, Francisco. Op. cit., Tomo II, vol. I, p. 349.
} 
"Ele entregará esta carta a Vossa Santidade, e ao mesmo tempo lhe há de referir em meu nome certas coisas que a ele mais largamente escrevo, e que são da maior necessidade para o bem e conservação da Companhia. Com toda a humildade suplico a Vossa Santidade que lhe dê em tudo inteiro crédito, e mande executar o que o dito Padre Leão Henriques lhe disser; pois são coisas de tanto peso e importância, que delas depende não somente a conservação e bom governo da Companhia, mas também de meus reinos e domínios, no que toca à Fé e costumes”461.

Está evidente que D. Sebastião estava se referindo aos cristãos novos, ele apenas não foi tão explícito quanto o Cardeal D. Henrique.

Inicialmente o Papa concordou que a Congregação não elegesse nenhum espanhol para o cargo de Vigário Geral. Posteriormente, talvez após o recebimento da carta de D. Sebastião, o Sumo Pontífice ordenou que a Congregação não escolhesse um espanhol para dirigir a Ordem. Os delegados se reuniram para discutir a decisão do Papa, ao qual deviam obediência. Escreveram um memorial pedindo-lhe que restituísse a autonomia da Congregação Geral. O pontífice anuiu. Mas voltou a enfatizar a sua preferência pela eleição de um padre que não fosse espanhol. Foi eleito o seu preferido, o belga Everardo Mercuriano. Juan Alfonso de Polanco não recebeu nenhum voto ${ }^{462}$.

É muito provável que os jesuítas portugueses se destacaram na campanha contra os cristãos novos ocorrida na terceira Congregação Geral. Especialmente o padre Leão Henriques, que como já foi visto, desde 1571 já era deputado do Conselho do Santo Ofício da Inquisição, e que, talvez por isso, ou seja, como “prêmio” ou promoção tenha substituído o Provincial Jorge Serrão. Ele era o homem

\footnotetext{
${ }^{461}$ Arquivo do Vaticano, Nunz., 4, f. 22. Évora, 20. 03. 1573. Citado por Rodrigues, Francisco. Idem, p. 34748.

${ }^{462}$ Ver a respeito Rodrigues, Francisco. Op. cit. tomo II, vol. I, pp. 254 - 57.
} 
de confiança tanto do Cardeal D. Henrique quanto do monarca D. Sebastião ${ }^{463}$. O padre Francisco Araújo, escreveu naquele período em seu "Breve Memorial" o seguinte a respeito da participação do jesuíta: “fez maravilhas, e foi mui honrado $e$ favorecido do Papa Gregório XIII, que tinha dito aos porteiros da Câmara que a toda hora o deixassem entrar livremente." ${ }^{464}$. E nas respostas às cartas do Cardeal e do monarca português escritas em 10 de setembro de 1573, o Papa Gregório XIII louvou o desempenho de Leão Henriques ${ }^{465}$.

O padre Manuel Rodrigues escreveu para o Geral Everardo Mercuriano a respeito do papel do padre Leão Henriques naquela Congregação:

"Um letrado que se encontrava em Roma no tempo da Congregação Geral, amigo do P. Leão Henriques, me disse que o P. fez com que não fosse eleito Polanco; já no ano passado o agente do cardeal havia escrito que o P. Leão Henriques fez maravilhas sobre a eleição, ou finezas." ${ }^{466}$

\section{A PRESENÇA ESPANHOLA NA III CONGREGAÇÃO GERAL}

Estavam presentes na terceira Congregação Geral quarenta e sete delegados. Dos quais apenas quatro eram portugueses. A maioria era de espanhóis. Portanto, quem decidiu a eleição de Everardo Mercuriano não foram os portugueses. Os jesuítas das Províncias espanholas já reproduziam naquele período o discurso da

\footnotetext{
${ }^{463}$ Sobre o papel de destaque dos jesuítas na terceira Congregação Geral da Companhia de Jesus ver Medina, Francisco de Borja. “Ignacio de Loyola y la Limpieza de Sangre.” In Juan Plazaola (Ed.), Ignacio de Loyola y su Tiempo. Congreso Internacional de Historia, 9 - 13 de septiembre de 1991. Bilbao, Ediciones Mensajero, 1992, p. 583. Ver também Salvador, José Gonçalves. Op. cit., p. 135 e Rodrigues, Francisco. Op. cit., tomo II, vol. I, p. 360. Os dois últimos historiadores asseguraram que os delegados portugueses tentaram aprovar o decreto de excluasão já na terceira Congregação Geral. Ė possível, já que esse era um dos propósitos do inquisidor geral português e muito provavelmnent, do monarca.

${ }^{464}$ Breve Memorial da Origem dsta Província da Companhia de Jesus de Portugal, que se gurda na Biblioteca da Universidade de Coimbra, ms. no 140. Citado por respeito Rodrigues, Francisco. Op. cit. tomo II, vol. I, p. 359.

${ }^{465}$ Arquivo do Vaticano, Brevi, armadio 44, tomo 22, f. 65-65v, 65v-66. Citado por Rodrigues, Francisco. Idem, ibidem.
} 
intolerância inquisitorial espanhola. Foi o que fez, por exemplo, o padre Navarro nas vésperas da Congregação, mais precisamente em 21 de fevereiro de 1573:

“ (...) tenha cuidado no delecto (sic) das pessoas que se recebem, especialmente na Espanha; porque o Rei e os grandes senhores e inquisidores têm muito pouca estima e menos confiança dos que não são limpos, e um inquisidor me disse, poucos dias há, que não encomendaria ofício nem governo a nenhum que fosse confesso, por santo e letrado que fosse, e sempre que lhe falo toca esta tecla." ${ }^{467}$.

Ou seja, não receber e não confiar nenhum cargo aos conversos. Mesma postura do inquisidor geral de Portugal.

A terceira Congregação Geral realizada entre 12 de abril 16 de junho de 1573 não conseguiu proibir o ingresso de cristãos novos na Companhia de Jesus, apesar de ter evitado que o cristão novo Juan Alfonso de Polanco fosse eleito para o cargo máximo da Ordem, Vigário Geral.

\section{CRISTÃOS VELHOS E CRISTÃOS NOVOS JESUÍTAS EM CONFLITO}

O problema dos conversos continuava presente e à espera de solução. Mas, afinal, qual seria a situação dos cristãos novos dentro da própria Companhia? Ou melhor, como se relacionavam cristãos novos e cristãos velhos jesuítas? Havia tolerância, harmonia, respeito, entendimento, enfim, como era a convivência entre eles? Por que o cardeal D. Henrique previu a destruição da Companhia de Jesus caso os cristãos novos continuassem a ser recebidos e a exercerem cargos de comando?

\footnotetext{
${ }^{466}$ Carta do p. Manuel Rodrigues para o Vigário Geral Everardo Mercuriano, escrita entre 08. 10. 1574. ARSI, Lus. 66, fls. 362-363; em particular fl. 363v. Citado por Marcocci, Giuseppe. Op. cit., p. 287.

${ }^{467}$ Citado por Astrain, Antonio S. J., Historia de la Compañía de Jesús en la Asistencia de España. Tomo III, Mercuriano-Acquaviva, 1573-1615. Madrid, Razón y Fe, JHS, 1909, p. 591 e Rey, Eusébio S. J. San Ignacio de Loyola y el Problema de los Cristianos Nuevos. Madrid, Razón y Fe, Revista Mensual Hispanoamericana, Publicada por Padres de la Compañía de Jesús, núms. 696-701, tomo 153, 1956, p. 191.
} 
Duas cartas do padre Miguel de Torres ${ }^{468}$ esclarecem, em grade parte, estas questões no que se refere ao caso português. Na primeira correspondência o quadro apresentado é crítico. Não havia harmonia entre cristãos novos e velhos cristãos velhos jesuítas. Também não havia respeito, tampouco caridade. A causa seria o ódio existente entre eles, o qual estava presente desde o nascimento. Em outras palavras, não se toleravam desde a infância. Portanto, não havia entendimento, conseqüentemente, a convivência era muito difícil. Propostas de solução para o problema dadas pelo padre Miguel de Torres: que o Vigário Geral proibisse o recebimento dos cristãos novos. Esta medida, dizia o jesuíta, praticamente resolveria todo o problema. Para pacificar os recebidos, o Vigário Geral devia estabelecer graves punições para quem provocasse alguma forma de desentendimento entre cristãos novos e velhos. Com isso eles se relacionariam com muita igualdade e fraterna caridade:

“ (...) a causa principal desta cizânia nesta Província me parece o ódio que desde a mama têm os cristãos velhos contra os novos. Seria grandíssima parte ou total remédio se se desse ordem que daqui por diante não se recebessem e que para pacificação dos recebidos [e par]a união que a Companhia pede entre todos dela se pusesse um grave preceito contra todos os que nesta matéria falassem uns contra outros, e para que no tratar os uns com os outros tratassem com muita igualdade e fraterna caridade" 469 .

A segunda carta do padre Miguel de Torres foi escrita cerca de três meses depois - 26. 11. 1574 - a qual foi também enviada para o Vigário Geral, Everardo

\footnotetext{
${ }^{468}$ Miquel de Torres era espanhol, exerceu o cargo de reitor do Colégio de Salamanca. Foi para Portugal como visitador em 1552 enviado por Inácio de Loyola para tentar restabelcer o entendimento entre os jesuítas daquela Província, durante a crise que envolveu o padre Simão Rodrigues. Em 1553 encerrou a visita. Entre 1555 e 1561 foi o Provincial de Portugal e tornou a ser visitador da mesma Província entre 1566-67. Ver Rodrigues, Francisco. A Companhia de Jesus em Portugal e nas Missões. Op. cit., pp. 15 e 19.
} 
Mercuriano. O conteúdo é basicamente o mesmo da correspondência anterior. Mudou apenas os termos utilizados. Quanto aos desentendimentos entre os cristãos novos e velhos, ele os classificou como “molesta e perniciosa desunião”, cuja causa seria "o intrínseco ódio ou aborrecimento que os cristãos velhos têm contra os novos mostrados com palavras e outras”. Houve uma proposta nova. Se alguém presenciasse qualquer um falando ou tratando mal o outro, seria por ele advertido e, logo a seguir, avisaria sobre o ocorrido ao superior. Devido ao respeito à autoridade do superior, pensava Miguel de Torres, a harmonia entre cristãos velhos e novos seria enfim conquistada ${ }^{470}$.

A situação dos cristãos novos relatada nestas duas correspondências era extremamente delicada. Os cristãos velhos jesuítas de Portugal não os suportavam. O motivo apontado pelo padre Miguel de Torres da causa dessa intolerância foi o “ódio intrínseco” que os cristãos velhos sentiam pelos conversos. Esse sentimento existia. Mas também havia, apesar das cartas de Miguel de Torres não revelarem com clareza, rivalidades entre cristãos novos e velhos dentre da própria Ordem. A Companhia tinha uma estrutura hierárquica bem estabelecida, com vários cargos e funções. A disputa por estes cargos era, também, uma das causas dos atritos entre cristãos velhos e conversos.

O cristão novo Cipriano Soares S. J., mestre em humanidades, escreveu em 1568 para o Vigário Geral Francisco de Borja deixando-o a par dos constrangimentos que o jesuíta, e cristão velho, Luís Gonçalves vinha lhe causando em Coimbra:

${ }^{469}$ Carta do p. Miguel de Torres para o Geral Everardo Mercuriano. Évora, 31 08. 1574. ARSI. Lus. 66, fl. 233rv. Citado por, Marcocci, Giuseppe. Op. cit., p. 289.

470 "A causa total ou quase única desta molesta e perniciosa desunião era devido ao intrínseco ódio ou aborrecimento que os cristãos velhos têm contra os novos mostrado exteriormente com palavras $e$ outras $e$ que me parecia que poderia ser grande remédio se ordenasse $V$. P. que daqui por diante não se admitisse nesta Província os novos, e para que a paz dos já admitidos e união de uns e dos outros mandasse severa e estreitamente que os direta nem diretamente (sic) nem falassem nem tratassem em prejuízo nem diminuição dos outros em público ou em segredo, mas antes que os que ouvissem isso os repreendessem e avisassem ao superior e poderia ser que este fosse bastante remédio, porque facilmente os menos principais seguiriam a doutrina e exemplo dos que têm mais autoridade e estes não há que duvidar senão que cumprirão à letra o que se lhes ordena." Carta do p. Miguel de Torres para o Geral Everardo Mercuriano. Évora, 26. 11. 1574. 
"Haverá oito anos (grifo nosso) que o P. Luís Gonçalves, ou por si ou por meio de outros, tem mostrado por modos esquisitos mais desafeição a minhas coisas do que se costuma, como creio, na Companhia, e Deus sabe o que se tem passado a este respeito..."471.

Em 1572 foi para Braga, onde exerceu o cargo de reitor daquele Colégio até 1574. Seu reitorado foi prejudicado porque os jesuítas cristãos velhos não queriam obedecer ao reitor porque ele era um cristão novo:

“ (...) o modo do padre Cipriano Soares, reitor deste Colégio, cuja virtude posto que seja grande e ponha grande cuidado para se acomodar, contudo não pode tirar de todo o que a natureza dá, porque como quer que os portugueses sejam mais sobre e malicioso não fica nada que não notem, e ainda que conheçam a virtude da pessoa não deixam de desgostar do modo, donde toma o demónio ocasião a tirar o gosto as coisas da obediência, e de se não ter o amor que se deve ao superior, disse também ele ser cristão novo de todos os quatro costados. E isto não somente sabem aqui os mais da casa, mas segundo tenho entendido a principal gente da cidade, e em casa do arcebispo, e o vigário geral daqui o conhece da sua terra e seus parentes e irmãos que aqui vem algumas vezes tratar em coisas de mercadoria e a mim me tem dito algumas pessoas tomar-se isto não muito bem em casa e creio que pior fora. E se não fosse sua virtude tomar-se-ia pior, isto digo a V. P. como pai que pode remediar tudo." ${ }^{472}$.

ARSI. Lus. 66, fl. 326. Citado por, Marcocci, Giuseppe. Idem, p. 290. Ver também Rodrigues, Francisco. Op. cit., tomo II, vol. I, p. 340.

${ }^{471}$ Arquivo Sociedade de Jesus, Lis. 62, f. 22. Coimbra, 22. 02. 1568. Autógrafo. Citado por Rodrigues, Francisco. Op. cit., tomo II, vol. I, p. 343.

${ }^{472}$ Carta de Gaspar de Barros para o Geral Francisco de Borja. Braga, 06. 01. 1572. ARSI, Lus. 64, fls. 241242v, em particular fl. 241. Citado por , Marcocci , Giuseppe. Op., cit., p. 286. 
Nota-se que ao mesmo tempo em que o autor da carta, Gaspar de Barros, apontou a discriminação dos jesuítas cristãos novos contra o reitor cristão novo, ele mesmo denunciou Cipriano Soares ao Geral por seu envolvimento no comércio dos seus irmãos e parentes.

Chegou um momento em o converso Cipriano Soares não suportava mais o anti-semitismo dos cristãos velhos da Companhia de Jesus. Em 19 de janeiro de 1574 ele voltou a escrever para o Vigário Geral Everardo Mercuriano reclamando os sofrimentos pelos quais passou durante os vinte e quatro anos na Companhia. Em função dos desgostos sofridos pediu que fosse transferido para a Espanha ${ }^{473}$. Deixou o cargo de reitor neste mesmo ano (1574). Em agosto de 1575 ainda se encontrava em Portugal. Numa carta escrita nesta data o Padre Manuel Rodrigues disse que ele "tinha modo de proceder muito grave e extraordinariamente granjeador de sua saúde $e^{474}$. Mas, provavelmente, sua transferência para a Espanha foi aceita. Entretanto, nem por isso, se pode afirmar que lá ele tenha encontrado a paz que desejava.

O Provincial Manuel Rodrigues ${ }^{475}$ reclamou que, enquanto os cristãos novos não eram recebidos na Província portuguesa, em Castela, além de ingressarem, eram enviados de lá para Portugal a fim de visitarem seus parentes, o que causava escândalo entre o povo e estimulava aos demais cristãos novos a irem para Castela onde seriam recebidos. O escândalo foi ainda maior depois que o cristão novo Garcia Suares visitou seus parentes em Évora: seu irmão saiu no auto-de-fé público. O problema com Garcia Suares ainda não havia encerrado. O Provincial da Andaluzia queria enviá-lo outra vez a Évora. Manuel Rodrigues disse que faria o possível para impedir o retorno do cristão novo àquela cidade, a fim de evitar que toda a Évora condenasse a Companhia de Jesus:

\footnotetext{
${ }^{473}$ Arq. S. J., Lus. 66, f. 24. Braga, 19. 01. 1574. Autógrafo. Citado por Rodrigues, Francisco. Op. cit., tomo II, vol. I, p. 344.

${ }^{474}$ Arq. S. J., Lus. 67, f. 165-162v. Carta de M. Rodrigues. Coimbra, 13. 08. 1575. Citada por Rodrigues, Francisco. Idem, p. 339.
} 
“Em Castela recebem Nossos Padres na Companhia alguns mancebos de Portugal que nesta Província não se recebem por ser cristãos novos e estar esta gente muito infamada neste Reino. E depois os enviam para cá para visitarem seus parentes, do que se escandaliza o povo vendo que agora se recebem na Companhia tão conhecidos cristãos novos, e que persuadem a outros a irem para Castela e lá os receberão. No ano passado veio da Província da Andaluzia a Évora com este escândalo que digo o padre Garcia Suares e depois que se foi, saiu um irmão seu ao cadafalso no ato público da Inquisição, com o qual se aumentou o escândalo. Agora quer o P. Provincial da Andaluzia enviá-lo outra vez a Évora: impedimolo como podemos, não sei se bastará. Se vier será notável a infâmia que aquela cidade conceberá da Companhia”, ${ }^{476}$.

Esta carta foi escrita entre o fim de 1574 e início de 1575. Portanto, apesar da terceira Congregação Geral não ter aprovado a proibição do recebimento dos cristãos novos, é muito provável que a Província portuguesa não estava mais recebendo-os, como indicou a carta de Provincial Manuel Rodrigues. Como indicou a missiva, além de não os receber, protestou contra a presença deles entre os cristãos velhos, mesmo em casos de visita, como aconteceu com Garcia Suares.

Em 1579, o padre Manuel Rodrigues voltou a escrever para o Geral Everardo Mercuriano tratando da questão dos cristãos na Espanha em geral e nas Províncias espanholas. Ele fez questão de informar ao Vigário Geral que todos os espanhóis tomavam extremo cuidado para se aproximar de um cristão novo, devido à grande infâmia dos conversos. Inclusive, dizia o jesuíta Manuel Rodrigues, o rei Felipe II,

\footnotetext{
475 O padre Manuel Rodrigues foi Provincial de Portugal entre 1574-80. Posteriormente exerceu o cargo de Assistente de 1581 a 1594. Ver Rodrigues, Francisco. A Companhia de Jesus em Portugal e nas Missões. Op. cit., pp. 15 e 20.

${ }^{476}$ Carta incompleta do p. Manuel Rodrigues, enviada provavelmente para o Geral Everardo Mercuriano, sem data, mas escrita entre o fim de 1574 e início de 1575. ARSI. Lus. 66, fl. 363a. Citada por Marcocci , Giuseppe. Op. cit., p. 291.
} 
apesar de admirar a Companhia, evitava contato com os jesuítas espanhóis para não se encontrar com algum converso. Estas informações dadas a Everardo Mercuriano teriam sido passadas para Manuel Rodrigues por um tal D. Theotonjo (sic). Naturalmente que a intenção do Provincial Manuel Rodrigues era deixar claro para o Vigário Geral que os jesuítas cristãos novos eram um estorvo para a Companhia de Jesus Espanha ${ }^{477}$.

No ano seguinte, 1580, o padre Manuel Rodrigues foi substituído pelo jesuíta italiano Sebastião de Morais. Nas instruções do Vigário Geral Everardo Mercuriano constava a proibição de fazer inquirições de genealogia aos que já haviam ingressado na Companhia de Jesus e tinham trabalhado nela de modo edificante. As inquirições deviam ser encerradas porque elas haviam causado notáveis amarguras e danos à Província ${ }^{478}$. Ou seja, mesmo depois de terem sido recebidos, os cristãos novos estavam sendo inquiridos a respeito de suas ascendências. A intolerância dos cristãos velhos contra os cristãos novos na Companhia de Jesus se aguçava.

A questão da convivência entre cristãos novos e velhos continuava grave na Província portuguesa. A situação do cristão novo Diogo Cisneiro estava insustentável. As hostilidades se generalizavam.

O novo Vigário Geral, Cláudio Acquaviva ${ }^{479}$, ao saber do que estava ocorrendo na Província lusitana, escreveu em 09 de setembro de 1581 para o Provincial de Portugal, Sebastião de Morais, com o intuito de alcançar o entendimento entre os cristãos novos e velhos. Recriminou a discriminação que os

\footnotetext{
477 "Acrescentou mais D. Theotonjo que na Espanha cristão novo ou converso (que assim se chama) é tão grande infâmia, como em Portugal ou mais, e que para um cavalheiro tomar algum criado se informa se é confesso e sendo não se atreve a tomar-lo, e que algunos religiosos, antes de receber o que pede sua religião, vão muito largos caminhos para saber se é confesso, para não recebê-lo. E que o Rei Felipe porque sabe que na Companhia há muitos na Espanha, embora sente bem de nosso instituto, não se aatreve a tratar com os nossos, para não acontecer-le tratar com algum confesso. Destas coisas me pareceu avisar a V. P. Carta do p. Manuel Rodrigues para o Geral Everardo Mercuriano. Évora, 04. 01. 1579. ARSI, Lus. 68, fls. 50-52v, em particular fl. 51v. Citada por Marcocci , Giuseppe. Op. cit., p. 293.

${ }^{478}$ Arquivo Sociedade de Jesus. Epp. NN., 1, f. 135v. Citado por Rodrigues, Francisco. Op. cit., tomo II, vol. I, p. 344.

${ }^{479}$ O padre Cláudio Acquaviva era natural de Atri, Itália. Antes de tornar-se Vigário Geral em 1581, foi reitor do Seminário Romano, em 1575 assumiu a reitoria do Colégio de Nápoles e no ano seguinte tornou-se Provincial da Província Napolitana. Em 1579 foi escolhido para ser o Provincial da Província Romana. Ver
} 
cristãos novos sofriam por parte dos cristãos velhos. Disse que esse era um sentimento secular e profano, inútil, contra a união e a caridade fraterna, portanto, não devia existir na Companhia. Esperava que a prudência do padre Sebastião de Morais fosse capaz de superar aquele “mal” repreendendo secreta a suavemente aos que cometessem a falta. Pediu ao Provincial que dissesse aos cristãos velhos portugueses que seu “desejo era de ver na Companhia grande união e espírito religioso".

Quanto ao cristão novo Diogo Cisneiro, sugeriu que fosse enviado para Roma, e os demais conversos fossem consolados e tirados daquela aflição pelo Provincial.

Devido à desunião entre os cristãos novos e velhos da Província, Cláudio Acquaviva recomendou cautela ao padre Sebastião de Morais na admissão dos cristãos novos $^{480}$.

Transcorridos três anos, o Vigário Geral Cláudio Acquaviva fez uma consulta ao então Assistente de Portugal, padre Manuel Rodrigues, a respeito da condição dos cristãos novos na Província lusitana. Ao respondê-lo em 22 de abril de 1584, Manuel Rodrigues disse que, devido à “notável deformidade e infâmia” que o problema dos conversos alcançou, o fundador da Ordem, Inácio de Loyola, caso estivesse vivo, impediria o ingresso dos cristãos novos. Em outras palavras, o Assistente português, em nome da Província, sugeriu ao Vigário Geral italiano que a Companhia de Jesus proibisse o recebimento dos descendentes de judeus:

O’Neile , Charles E. S. I., E Domínguez, Joaquín M. ${ }^{a}$ S. I. Diccionario Histórico de la Compañía de Jesús Biográfico-Temático. Op. cit., vol. II, p. 16-14.

480 "Tenho muita pena, dizia, de que essa má disposição, tão secular e profana, de sentir e falar desfavoravelmente dos Nossos que têm sangue de cristãos novos, esteja tão introduzida nessa Província, como me informaram. Confio em Deus que o mal se irá com a prodência de V. R. De mim pode insinuar aos Nossos a seu tempo, que me dá Nosso Senhor grande desejo de ver na Companhia grande união e espírito religioso. Por isso sou de parecer que V. R. não deve dissimular, quando se fale desse modo em público, mas avisar secretamente e com suavidade aos que faltarem... Certamente haverá o superior de ir com muito tento em admitir de novo semelhantes pessoas, como de certo convém especialmente nessa Província, onde são tão mal vistos; mas dos que estão já recebidos, é claro que essas murmurações são, não somente de nenhuma utilidade, mas sim contra a união e caridade fraterna, a qual confio que Nosso Senhor ajudará a manter e 
"Dize-se que se nosso padre Inácio agora vivera deixaria a coisa mais apertada nas Constituições; e que todavia assim como as deixou é este impedimento da raça, segundo eles, essencial ou muito próximo ao essencial, por causa da notável deformidade e infâmia que no tempo do nosso padre Inácio ainda não era tão descoberta como agora.”

O padre Manuel Rodrigues esclareceu melhor, ao longo da carta, o significado das "deformidades e infâmias" dos cristãos novos da Companhia. Os conversos eram "astutos e fingidos," com eles a vida religiosa ia mal e a união seria impossível. Quando são superiores, dizia o jesuíta cristão velho, se preocupam apenas em coisas exteriores, a "verdadeira mortificação" é pouco promovida assim como as "virtudes sólidas". Eram poucos zelosos com as partes $5^{\mathrm{a}}$ e $6^{\mathrm{a}}$ das Constituições e admitiam com facilidade outros cristãos novos muito indignos:

“Sendo tão filhos deste século, astutos, fingidos..., certo é que irá com eles muito mal a vida religiosa e que não poderá nela haver união [...]. Se a alguns com este sangue fazem superiores: promovem pouco a verdadeira mortificação e virtudes sólidas, ..., são poucos zelosos de executar-se com perfeição a $5^{\mathrm{a}}$ e $6^{\mathrm{a}}$ partes das Constituições e admitem facilmente outros do mesmo sangue muito indignos".

Na sociedade, a reputação dos cristãos novos era a pior possível:

"Nas partes onde vivem ou fazem comércio são considerados judeus ou suspeitos na fé ou, ao menos, tão dispostos a deixá-la que basta um velha para converter ao judaísmo homem batizados, doutrinados e feitos letrados entre cristãos e tidos como homens de más consciências,

aumentar. O P. Diogo Cisneiro poderá V. R. enviá-lo a Roma. Os demais, que lhe parecer, convém consolálos e tirá-los da aflição.” Citado por Rodrigues, Francisco. Op. cit., tomo II, vol. I, pp. 344-45. 
enganadores, contrários aos bons costumes, prejudiciais à República, de baixa condição.... São tão inimigos dos cristãos e também se sabe que deles saem muitas informações para o Turco e outros Reis infiéis contra a cristandade".

Por fim, acusou Juan Alfonso de Polanco de ter acelerado a morte do Vigário Geral Francisco de Borja para assumir o seu lugar: “dize-se que acelerou a morte do P. Francisco de Borja ... para ser eleito Geral" ${ }^{\text {481 }}$.

Cerca de um ano depois, mais exatamente em 15 de julho de 1585, Cláudio Acquaviva, Vigário Geral da Companhia de Jesus há quatro anos, escreveu para o Provincial de Portugal, padre Sebastião de Morais, recomendando-lhe que não colocasse cristãos novos em cargos de comando a fim de evitar escândalo tanto dentro quanto fora da Companhia ${ }^{482}$.

O Geral da Companhia fechava mais uma porta para os cristãos novos. Primeiro recomendou que não fossem recebidos em Portugal, agora orientou para não serem elevados a postos de comando. O jesuíta italiano estava cedendo, gradativamente, ao anti-semitismo lusitano.

Em janeiro de 1589 o padre Leão Henriques voltou a criticar os cristãos novos. Seu alvo foi os conversos proeminentes. Passavam da humildade à condição de senhores assim que alcançavam autoridade e crédito. Obtido o reconhecimento, tornavam-se egoístas e queriam que todos os servissem. Leão Henriques dizia conhecer pessoalmente alguns desses casos:

“ (...) procedem ao princípio com muita edificação e humildade, e como tenham alcançado autoridade e crédito, fazem-se uns como senhores, e trocam-se de maneira, que dão que falar a todos com seu bom

\footnotetext{
${ }^{481}$ Inst. 184/II 360-364. Citado por Medina, Francisco de Borja. Ignacio de Loyola y la Limpieza de Sangre”. Op., cit., p. 584-85.

${ }^{482}$ Arq. S. J., Epp. NN., 1, f. 183v. Carta (minuta) do Geral a Sebastião de Morais. Roma, 15. 07. 1585. Citado por Rodrigues, Francisco. Op. cit., tomo II, vol. I, p. 345.
} 
tratamento, não têem conta senão consigo mesmo, e querem que todos os sirvam, e disso tenho visto alguns exemplos”483.

Em 1593 Manuel Rodrigues voltou a escrever contra os cristãos novos da Companhia de Jesus. O ataque se concentrou nos conversos da Espanha. Apesar de serem cristãos, dizia Manuel Rodrigues, tinham péssima inclinação e eram de natureza contrária ao verdadeiro e sincero espírito da religião. Em virtude deste caráter, a admissão dos cristãos novos havia causado muitos danos à Companhia, prejudicava tanto a sua essência quanto seu bom nome ${ }^{484}$.

Demonstrou seu repúdio aos cristãos velhos espanhóis por negarem as evidências a respeito dos inconvenientes causados pelos cristãos novos à Companhia de Jesus. Além disso, dizia Manuel Rodrigues, os espanhóis cristãos velhos entendiam que os conversos deviam ser admitidos, promovidos e exaltados ${ }^{485}$.

Portanto, dois dos mais insignes jesuítas de Portugal, Manuel Rodrigues e Leão Henriques se destacaram na tarefa de elencar as características negativas dos cristãos novos. Essa era a verdade deles e daqueles por eles representados.

Entretanto, como já foi salientado anteriormente, supõe-se que havia uma campanha relativamente orquestrada, veladamente, para desprestigiar os cristãos novos com o objetivo de excluí-los da Companhia e com isso livrar-se deles na acirrada conconcorrência por cargos e postos na Ordem.

Em novembro de 1564 o padre Diego Mirão escreveu paro o Vigário Geral da Companhia de Jesus, Diego Lainez, expondo os motivos pelos quais ele e o padre Luiz Gonçalves achavam inconveniente receber cristãos novos em Portugal, mesmo nos casos em que os conversos aceitos fossem enviados para outras províncias fora de Portugal. Esta carta foi escrita para o Geral em resposta a uma missiva escrita

\footnotetext{
${ }^{483}$ Arq. S. J., Lus. 70, f. 375. Carta de Leão Henriques para o Geral Cláudio Acquaviva. Lisboa, 26. 01. 1589. Citado por Rodrigues, Francisco. Op. cit., tomo II, vol. I, p. 339.

${ }^{484}$ Inst. 186e 327-351v. Citado por Medina, Francisco de Borja. "Ignacio de Loyola y la Limpieza de Sangre.” Op. cit., p. 585.

${ }^{485}$ Inst. 186e 327-351v. Citado por, Francisco de Borja. “Ignacio de Loyola y la Limpieza de Sangre.” idem, p. 585.
} 
pelo secretário particular de Diego Lainez, Juan Alfonso de Polanco, tratando do mesmo assunto.

Uma das razões para não recebê-los era porque, “ lhes têm os principiais e o povo muito pouco crédito e se resguardam muito deles". Por exemplo, dois pais que tinham filhos e filhas professas foram condenados pelo Santo Ofício por judaizarem, relatava Diego Mirão. O padre Luiz Gonçalves apontava como motivo dos casos de cripto-judaismo a conversão violenta dos judeus de Portugal ao catolicismo. Caso a Província de Portugal recebesse os cristãos novos, argumentava o padre Luís Gonçalves, e os enviasse para outras Províncias, diriam que isso seria uma prova de grande consideração que a Companhia tinha pelos conversos, pois para não deixar de recebê-los, os enviavam para lugares onde fosse mais cômodo o ingresso dos cristãos novos ${ }^{486}$.

O cristão novo João Lopes manifestou grande interesse em receber o título de fundador do Colégio de Todos-os-Santos, localizado em Ponta Delgada, na ilha de São Miguel. Ele havia feito doações para a sua construção. Entretanto, os jesuítas não estavam dispostos a conceder o título solicitado pelo cristão novo. Os motivos alegados eram a péssima reputação dos conversos, principalmente, naquele período em que a grande maioria estava sendo condena pelo Santo Ofício da Inquisição. O padre Fernão Guerreiro escreveu para o Geral Cláudio Acquaviva em 2 de agosto de 1592 dizendo-lhe quem era João Lopes e o que ele desejava ${ }^{487}$. Não se sabe o desfecho do caso, mas é muito provável que o Vigário Geral não tenha concedido o título de fundador do Colégio de Todos-os-Santo ao cristão novo João Lopes, porque, como mencionado anteriormente, em 15 de julho de 1585 Cláudio Acquaviva já havia orientado o Provincial de Portugal, padre Sebastião de Morais, a não colocar cristãos novos em cargos de comando. Um títuto de fundador era algo

\footnotetext{
${ }^{486}$ Carta do p. Diego Mirão para o Geral Diego Lainez. Lisboa, 12. 11. 1564. Arq. S. J., Lus. 71, f. 266, 270 et alibi. Citada por Rodrigues, Francisco. Op. cit., tomo II, vol. I, p. 341.

487 “... Como é da nação dos cristãos novos gente por cá tão mal vista (principalmente nestes tempos em que tão poucos escapam nestes reinos que não sejam presos), que falar em um desses é falar em uma coisa
} 
que dava prestígio, portanto, seria inconveniente para os jesuítas, naquele momento, promover um cristão novo. A concessão do título poderia causar protestos tanto dos jesuitas cristãos velhos quanto dos cristãos velhos em geral, principalmente dos que trabalhavam para a Inquisição.

\section{O ANTI-SEMITISMO EM ASCENSÃO}

Neste mesmo ano - 1593 - Manuel Rodrigues escreveu para a Quinta Congragação Geral solicitando a exclusão total dos cristãos novos da Companhia de Jesus, inclusive daqueles que demonstrassem ser cristãos e constantes na fé. Para o padre Manuel Rodrigues, caso a Congregação Geral acatasse sua proposta, estaria realizando a intenção do fundador da Companhia de Jesus, Inácio de Loyola ${ }^{488}$.

O padre Manuel Rodrigues usou este argumento porque, de Lisboa, o padre Amador Rebello enviou para o assistente Manuel Rodrigues em Roma uma carta atribuída a Francisco Xavier, na qual ele deixou claro que o fundador da Companhia, Inácio de Loyola, foi favorável à exclusão dos cristãos novos ${ }^{489}$.

O jesuíta Fernando Rebello, professor de teologia da Universidade de Évora, também utilizou a mesma carta de Francisco Xavier, a qual foi enviada ao Vigário Geral Cláudio Acquaviva e à Quinta Congregação Geral, como uma das justificativa para a Companhia de Jesus impedir a admissão dos cristãos novos: "por ser segundo a intenção de N. P. Inácio como testifica o P. Mestre Francisco Xavier em algumas cartas cujo exemplar há em Portugal." O segundo argumento utlizado pelo professor de teologia da Universidade de Évora justificando a exclusão

\footnotetext{
abominável e indigna de que os homens a vejam.” Extrato da Carta do Padre Fernão Guerreiro para o Geral Cláudio Acquaviva. Angra, 02. 08. 1592. Citada por Marcocci , Giuseppe. Op., cit., p. 295.

${ }^{488}$ Inst. 184/II 356 e Inst. 186e 337v. Citados por Francisco de Borja. "Ignacio de Loyola y la Limpieza de Sangre.” Op. cit., p. 586.

489 Inst. 184/I 327. Citados por Francisco de Borja. “Ignacio de Loyola y la Limpieza de Sangre.” Idem., p. 587. Trata-se da instrução que o padre Francisco Xavier escreveu para Gaspar Barzeo em abril de 1552, a qual já foi analisa. A hipótese levantada foi a de que Francisco Xavier forjou o conteúdo da carta, ou seja, Inácio de Loyola não teria proibido o recebimento dos cristãos novos. Mantêm-se esta hipótese, a qual não exclui que tenham sido os jesuítas anti-semitas que tenham forjado esta carta visando a exclusão na Quinta Congregação Geral.
} 
dos cristãos novos foi que na Espanha, dizia ele, os conversos estão excluídos dos cargos honrosos e dos Colégios Universitários ${ }^{490}$.

Conforme Francisco de Borja Medina, S. J. Fernando Rebello teria incluído os cristãos novos entre os autores dos memoriais e os problemas por eles causados à Companhia. Por mais este motivo teria advogado a exclusãos dos mesmos da Companhia de Jesus. ${ }^{491}$.

Algo semelhante aconteceu com o também português Francisco Teófilo S. J. Ele afirmou em carta enviada para o Geral Cláudio, a qual somente deveria ser lida na Congregação Geral, que a grande maioria dos autores dos memoriais era de cristãos novos $^{492}$.

\footnotetext{
${ }^{490}$ F. Rebello "al muy Rdo. Pe. N. en Xto., el P. Claudio Acquaviva, Prepos. Gen. de la Compañía de Jesús y definidores de la C. G." Congr. 20b/II 620-621. Citado por Medina, Francisco de Borja. "Ignacio de Loyola y la Limpieza de Sangre." Op. cit., p. 587.

491 “F. Rebello 'Al muy Rdo. Pe. N. en Xto., el P. Cláudio Acquaviva, Prepos. Gen. De la Compañía de Jesús y definidores de la C. G.." " Congr. 20b/II 620-621. Citado por Medina, Francisco de Borja. "Ignacio de Loyola y la Limpieza de Sangre.” Op. cit., p. 609. Citado por Medina, Francisco de Borja. "Ignacio de Loyola y la Limpieza de Sangre.” Op. cit., p. 610.
} 


\section{CAPÍTULO VIII. A COMPANHIA DE JESUS, OS CRISTÃOS NOVOS, A INQUISIÇÃO E A NOBREZA ESPANHOLAS}

\section{A COMPANHIA DE JESUS E O TRIBUNAL DO SANTO OFÍCIO DA}

INQUISIÇÃO NA ESPANHA

A situação dos cristãos jesuítas espanhóis não foi muito diferente da portuguesa. A Companhia de Jesus também esteve presente na Inquisição espanhola. Em 1545 os jesuítas já confessavam os prisioneiros em Valladolid: “foram escolhidos pelo Santo Ofício da Inquisição dois doutores dos nossos, colegiais, para confessar a gente de sua prisão; e assim se fez com muita satisfação deles ${ }^{493}$.

Em 1549, o padre Diego Lainez, cristão novo, pregou no auto-de-fé realizado em Palermo, atendendo ao chamado do inquisidor Bartolomé Sebastián:

"Fazendo-se aqui auto de Inquisição, me fez chamar o Inquisidor para rogar-me predicasse nele; e assim se fez, achando-se o Sr. Vice-rei presente e a Sra. Vice-rainha (Juan de Veja e Leonor de Ossorio), com as

\footnotetext{
492 Carta de 21 de novembro de 1593. Congr. 26/bII 321-324. Citado por Medina, Francisco de Borja. “Ignacio de Loyola y la Limpieza de Sangre.” Idem, p. 610.

${ }^{493}$ Circular escrita por Juan de Polanco entre 21-26 de abril de 1545. In Polanci Complementa I, p. 622. Citado por Novalin, José Luís Gonzales. Op. cit., p. 36, nota 92..
} 
pessoas principais da cidade e com grande povo. Espero em Deus N. S. que haverá sacado algum fruto de seu serviço e bem daquelas almas.” ${ }^{\text {„94 }}$.

O Provincial Antônio Araoz disse que a Inquisição "é atalaia e guarda contra os hereges”495. Enquanto o futuro Vigário Geral da Companhia, padre Francisco de Borja, assim se referiu à Inquisição ao relatar o auto-de-fé ocorrido em 21 de maio de 1559 em Valladolid: “... juntamente com ser de grande dor foram de grande consolação, por ser remédio do dano recebido e nova causa de graças ao Senhor pelo favor que fez à Espanha em deixar-lhe estas colunas do Santo Ofício por torre de homenagem e fortaleza da Igreja romana." ${ }^{496}$.

\section{OS CONVERSOS E A INQUISIÇÃO}

Apesar dos serviços que a Companhia de Jesus vinha prestando ao Tribunal do Santo Ofício espanhol, a partir dos anos setenta do século XVI a Inquisição espanhola começou a resistir à presença dos converos na Companhia de Jesus. Em 1570 houve um mal estar entre o Tribunal e a Ordem. O Santo Ofício espanhol anulou o parecer que a Inquisição Romana havia solicitado ao cristão novo Francisco de Toledo sobre as acusações que o Santo Ofício da Inquisição espanhola havia formulado contra o Arcebispo de Toledo, Bartolomeu de Carranza. O parecer absolvia o Cardeal contra a acusação de heterodoxia no catecismo que ele compôs. O Santo Ofício desligitimou o parecer de Francisco de Toledo, entre outras coisas, por ele ser cristão novo ${ }^{497}$.

\footnotetext{
${ }^{494}$ Carta de Diego Lainez para o Geral Inácio de Loyola, maio de 1549. In Lainii Monumenta I. Matrit, 1912, pp. 129-30. Citado por Novalin, José Luís Gonzales. Op. cit., p. 36, nota 93.

${ }^{495}$ In Lainii Monumenta IV, P. 256. Citado por Novalin, José Luís Gonzales. Idem, p. 50. A Companhia de Jesus na Espanha também participou da censura inquisitorial de livros. Ver a esse respeito Novalin, José Luís Gonzales. Idem, pp. 40-41 e p. 55.

${ }^{496}$ Carta de Francisco de Borja. Lainii Monumenta. Epistolae et Acta. Patris Jacobi Lainii, Tomus Quartos (1558-1560). Matrit, 1915, pp. 361.
} 


\section{OS CONVERSOS E A NOBREZA}

O mal estar não se restringia ao Santo Ofício. Em Córdoba, por exemplo, os alunos do Colégio jesuíta da cidade não ingressavam na Companhia de Jesus porque a nobreza dizia que o todos os seus alunos eram judeus. Por isso todos os filhos da nobreza ingressavam no monastério São Paulo, dos dominicanos. Caso alguns deles optassem pela Companhia de Jesus, a desonra seria equivalente à causada pelo uso do sambenito:

“El colegio de Córdoba tiene mas de seiscientos estudiantes, entre ellos toda la nobleza de los hijos de los caballeros de Córdoba, que es mucha y muy limpia sangre, y aficionándose muchos de ellos a religión y a la nuestra, por nuestro pecado, no entra hombre de ellos en la Compañía, sino todos se entran en S. Pablo, monasterio de dominicos. Y la razón de esto es, porque nuestro colegio está muy infame entre los caballeros, de que no entran el él, sino judíos - hablo con su frases -. Y dicen que S. Pablo es el monasterio de los caballeros, Y esto está tan de cal y canto, que si por desdicha entre alguno acá, hay tan grande sentimiento como si a su linaje echasen algún sambenito. I sepa V. P. que para Córdoba es terrible esta fama." ${ }^{498}$.

É possível que o padre Ramírez tenha exagerado ao dizer que nenhum filho da nobreza de Córdoba ingressava na Companhia, contudo, ele estava sendo franco ao afirmar que a nobreza da cidade era contra a presença de cristãos novos no Colégio jesuíta. Pois, quando formados, os cristãos novos iriam concorrer com os

\footnotetext{
${ }^{497}$ Ver a respeito do processo do Cardeal Bartolomeu Carranza a obra do historiador jesuíta Astrain, Antonio. Historia de la Compañía de Jesús en la Asistencia de España. Tomo III, Mercurian - Acquaviva (Primera Parte), 1573-1615. Op. cit., p. 591 e O’Malley, John W. Op. cit., pp. 487-92, especialmente pp. 491-92.

${ }^{498}$ Carta do padre Ramírez para o Prepósito Geral Francisco de Borja. Córdoba, 01. 09. 1572. Arch. Rom. S. J., Epist. Hisp., XVIII, f. 314. Citado por Rey, Eusebio S. I. Op. cit., p. 191. Ver também Astrain, Antonio. Historia de la Compañía de Jesus en la Asistencia de España. Tomo III, Mercurian - Acquaviva (Primera Parte), 1573-1615. Op. cit., p. 591.
} 
nobres em condições de igualdade cultural e intelectual. Concorrer, inclusive, por vagas a cargos, na época cobiçados, na própria Companhia.

Em carta acima menciona, o padre Navarro advertia à direção da Companhia em Roma que era necessário que a Ordem tivesse cautela em receber cristãos novos, porque o rei, a nobreza e os inquisidores tinham pouca estima e confiança nos conversos. Um dos inquisidores teria lhe dito, em várias oportunidades, que não confiaria a nenhum cristão novo, por mais santo e culto que fosse, cargo ou governo $^{499}$. Claro está que a intenção do inquisidor era deixar claro para o jesuíta que a Companhia deveria pensar e agir como ele, a Inquisição, o rei e a nobreza em relação aos conversos.

Respondendo a estas e outras demandas do gênero o Prepósito Geral da Companhia de Jesus, Everardo Mercuriano, em 13 de julho de 1577 escreveu para o Provincial da América Portuguesa, padre José de Anchieta, dizendo-lhe que, em função da opinião dominante entender que o recebimento de cristãos novos desedificava a Companhia de Jesus, os jesuítas não deveriam recebê-los, nem tampouco qualquer pessoa que pudesse causar escândalo para a Ordem: "Entende-se cá que desedifica a gente de que recebamos cristãos novos na Companhia; por isso não deverão admitir tal sorte de pessoas, nem ainda outras que possam escandalizar ${ }^{\mathrm{5} 00}$. Menos de dois anos depois - em 15 de janeiro de 1579 - a mesma norma proibindo o ingresso dos conversos foi renovada ${ }^{501}$.

Na expressão "entende-se cá”, o sujeito está oculto, portanto, os jesuítas poderiam estar envolvidos entre aqueles que entendiam que o recebimento dos cristãos novos “desedificava” os inacianos.

\footnotetext{
499 Citado por Astrain, Antonio S. J. Idem, p. 591.

${ }^{500}$ Carta do Vigário Geral Everardo Mercuriano para o Provincial da América Portuguesa, José de Anchieta. Roma, 13. 07. 1577. Citada por Salvador, José Gonçalves,. Cristãos novos, Jesuítas e Inqusição. Aspectos de sua Presença nas Capitanias do Sul, 1530-1680. São Paulo, Livraria Pioneira Editora, Editora da Universidade de São Paulo, 1969, p. 135.

${ }^{501}$ Idem, ibidem. Voltaremos a esta tema quando tratarmos da Província brasileira.
} 


\section{A ITÁLIA NÃO ERA MAIS A MESMA}

Um fato novo, revelador da situação delicadíssima na qual se encontravam os cristãos novos na Companhia de Jesus, aconteceu com o jesuíta italiano Lorenzo Maggio, que exercia a função de assistente. Ele escreveu em novembro de 1585 - na resposta a uma consulta do Prepósito Geral Cláudio Acquaviva sobre os conversos que se dependesse da condição da sua natureza, herdada dos seus antepassados, os cristãos novos jamais seriam bons cristãos. Caso houvesse algum bom cristão entre eles, seria devido ao dom especial da graça ${ }^{502}$.

Aquela Itália de passado recente, quer dizer, a dos anos quarenta e cinquenta do século XVI, onde Roma representava o refúgio dos cristãos novos jesuítas, o lugar no qual se "exilavam” sob a proteção do Vigário Geral e fundador da Companhia de Jesus, Inácio de Loyola, emitia sinais inequívocos de que não mais existia. O anti-semitismo ibérico demonstrou, através do padre Lorenzo Maggio, que estava "contaminando" o berço do humanismo.

Em 26 de maio de 1586 o padre Pablo Hernández escreveu para o Geral Cláudio Acquaviva dizendo-lhe que a Inquisição espanhola desejava saber "Por que recebiam na Companhia a cristãos novos? E já que os recebêssemos, por que os levantávamos a cargos insignes de Reitores, Provinciais e Visitadores?’503.

\section{INTENSIFICAÇÃO DA PRESSÃO DA INQUISIÇÃO CONTRA OS}

\section{CRISTÃOS NOVOS}

A pressão do Tribunal do Santo Ofício sobre a Companhia de Jesus havia, portanto, se tornado mais intensa quanto ao recebimento de cristãos novos na Ordem. Como consta na carta do padre Pablo Hernández foram três as perguntas formuladas pelo Santo Ofício, sendo que entre elas, a relativa ao ingresso dos conversos na Companhia foi formulada em primeiro lugar. Mais um indicativo da

\footnotetext{
502 “De naevis Societatis causijs ac remedijs eorumdem”. Inst. 107 27. Citada por Medina, Francisco de Borja. "Ignacio de Loyola y la Limpieza de Sangre.” Op. cit., pp. 611-612.

${ }^{503}$ Epist. Hisp. XXVIII, f. 65. Citado por Astrain, Antonio S. J. Op. cit., p. 369.
} 
importância cada vez maior que a Inquisição espanhola passava a dar à questão da presença dos cristãos novos entre os inacianos.

A carta do inquisidor do Tribunal de Granada, Salcedo, datada em 14 de novembro de 1587, esclarece o motivo da pergunta acima mencionada. Ele disse para o Vigário Geral, Cláudio Acquaviva, que ficasse ciente de que era muito importante para os espanhóis que o governo e postos de importância fossem ocupados por pessoas "limpas". E que evitasse receber quem não fosse "limpo", especialmente os que tivessem a "fama” de não serem, pois assim faziam as demais religiões da Espanha, o que lhes havia poupado problemas ${ }^{504}$.

O inquisidor Salcedo não deixou claro quem não desejava que os conversos ocupassem cargos de comando e que não fossem admitidos os cristãos novos mais notórios. Ele disse apenas que as religiões já adotavam estes procedimentos. Mas não é difícil deduzir que, além da discriminação das religiões, os conversos estavam sendo discriminados pela nobreza espanhola, como demonstrou, por exemplo, o caso já relatado do Colégio de Córdoba.

\section{DESINTELIGÊNCIAS ENTRE A COMPANHIA E A INQUISIÇÃO E A QUESTÃO DOS MEMORIAIS}

A partir de 1586 ocorreram uma série de problemas de competência jurisdicional entre a Companhia de Jesus e o Tribunal do Santo Oficio espanhol. Entre estes estava o caso da absolvição do “crime” de solicitação ${ }^{505}$. O Tribunal chegou a prender alguns padres jesuítas acusados deste "crime”. Na contenda envolveram-se o rei da Espanha, Felipe II e o papa Sisto V. Ambos ficaram a favor da Inquisição. Em meio a estas desinteligências surgiu uma série de memoriais que,

\footnotetext{
504 "Eu sou inquisidor de Granada e sem conhecer V. P. me atrevo a escrever estas linhas, por ser tão aficcionado á Companhia, que ninguém pode ser mais, somente para suplicar a V. P. se sirva de advertir a uma coisa que seria de muito momento para cá, e é pôr nos governos e postos grandes, pessoas limpas, e daqui por diante, guardar-se de receber as que não o são; especialmente os muito notados nisso, como fzem as demias religiões da Espanha e se hão achado e se acham muito bem com isso." Citado por Astrain, Antonio S. J. Idem, p. 592 e por Rey, Eusébio. Op. cit. p. 192.

${ }^{505}$ A solicitação consistia na tentativa do confessor em seduzir a confessada.
} 
entre outras coisas, questionavam a centralização do poder da Companhia de Jesus em Roma, representada pelo Prepósito Geral. Durante a Quinta Congregação Geral, como um dos motivos para excluí-los, os cristãos novos serão apontados como autores daqueles memoriais ${ }^{506}$.

No dia 25 de janeiro de 1588 o papa Sisto V publicou o breve "Dudum Charissimi”, o qual proibia que os cristãos novos obtivessem qualquer benefício eclesiástico. O pontífice Sisto $\mathrm{V}$, como acima mencionado, na contenda entre a Inquisição espanhola e a Companhia de Jesus, posicionou-se a favor do Santo Ofício. A publicação do breve pode ter ocorrido para atender à possível demanda do Tribunal. Os conversos tentaram, inutilmente, anular o breve, inclusive, após o falecimento do papa Sisto $\mathrm{V}$ ocorrido em $1590^{507}$. A manutenção do breve demonstra que os anti-semitas haviam se fortalecido de maneira ameaçadora. Os acontecimentos recentes indicavam que seria somente uma questão de tempo a exclusão da Companhia de Jesus.

\section{A NOBREZA SE DECLAROU ANTI-SEMITA}

Entre setembro e outubro de 1590, a nobreza de Castela finalmente se manifestou abertamente a respeito da presença dos conversos entre os jesuítas. $\mathrm{O}$ marquês de Velada levantou a hipótese de que os conflitos existentes entre a Companhia de Jesus e a Santa Inquisição estavam sendo causados pelos cristãos novos. Propôs então que a Ordem restringisse o recebimento deles ${ }^{508}$.

\footnotetext{
${ }^{506}$ Sobre a questão jurisdicional enter a Companhia de Jesus e a Inquição espanhola e o problema dos memorias com seus descobramentos ver a analise pormenorizada de Rodrigues, Francisco. Op. cit. pp. 374575. Quanto aos memoriais ver espacialmente pp. 402-420.

${ }^{507}$ Biblioteca Nacional de Lisboa. Col. Moreira. Liv. ms. 863, p. 32v. Citado por Salvador, José Gonçalves. Op. cit., p. 5.

${ }^{508}$ Ver a respeito, Astrain, Antonio. Op. cit., p. 498.
} 


\section{CLÁUDIO ACQUAVIVA TORNOU-SE ANTI-SEMITA}

Em 18 de abril de 1590 o Vigário Geral, Cláudio Acquaviva, engrossou a fileira dos jesuítas contrários aos cristãos novos. Ele escreveu uma ordem secreta para os provinciais espanhóis proibindo a admissão dos conversos e o acesso a cargos aos que já haviam sido admitidos ${ }^{509}$.

Em 1592 o Geral Cláudio Acquaviva voltou a escrever aos provinciais espanhóis ordenando-os a não receber os cristãos novos. Mandou que procedessem com discrição a esse respeito ${ }^{510}$. Essa segunda ordem evidencia que a primeira não foi rigorosamente aplicada e que o tema da exclusão dos conversos ainda era delicado para a Companhia, já que era necessário ser discreto ao discriminar os cristãos novos.

No dia 4 de junho de 1592 o padre Bartolomé Pérez, Provincial da Andaluzia, escreveu para o Prepósito Geral, Cláudio Acquaviva, apoiando a proibição do recebimento dos cristãos novos. Para ele a decisão foi importante e necessária porque convinha à Companhia de Jesus ir se purificando de tantos conversos, já que os mesmos causavam grande dano moral e ofendiam muita gente importante, principalmente aos membros do Tribunal do Santo Ofício ${ }^{511}$.

\section{O ATAQUE DE ALONSO SANCHES CONTRA OS CRISTÃOS NOVOS E O}

\section{CASO DO PADRE JOSÉ DE ACOSTA}

Em 24 de março de 1593 o padre Alonso Sánchez teve uma audiência com o rei da Espanha, Felipe II. Trataram a respeito do cristão novo jesuíta José de Acosta $^{512}$ e dos demais conversos da Companhia de Jesus.

\footnotetext{
${ }^{509}$ Ver Medina, Francisco de Borja. “Ignacio de Loyola y la Limpieza de Sangre.” Op. cit., p. 613.

${ }^{510}$ Ver a respeito Astrain, Antonio. Op. cit., p. 592.

${ }^{511}$ Idem, ibidem. Ver também Rey, Eusébio. Op. cit. p. 192.

${ }^{512}$ O padre José de Acosta havia sido Provincial no Peru e era um homem de confiança de monarca espanhol. Se envolveu diretamente com o problema dos memorilista, visitando as Províncias da Espanha visando restabelecer a ordem , quer dizer, corrigir os erros causados pelos rebeldes memorialistas.
} 
Alonso Sánchez afirmou ao monarca que o padre José de Acosta era um homem dominado pela ambição. Através dos seus sermões honrosos, continuou o jesuíta, procurava ganhar a simpatia dos príncipes e dos grandes: "se há deixado levar pela ambição, procurando sermões honrosos e desejando ganhar a vontade de príncipes e grandes”. Segundo informações recebidas de um cortesão, Alonso Sánchez disse que José de Acosta estava enganando a Felipe II ao tentar convencêlo de que ajudava aos bons cristãos velhos da Companhia, sendo que, na realidade, auxiliava somente aos poucos e maus e aos cristãos novos.

Quanto ao papel exercido pelos cristãos velhos e novos, Alonso Sánchez teceu os seguintes comentários para o monarca espanhol: toda a história de sucesso da Companhia havia sido conquistada pelos cristãos velhos seguidores dos fundadores da Companhia de Jesus, inclusive de Inácio de Loyola. Em nada tinham contribuído os inovadores, ou seja, os memorialistas. A grande maioria dos cristãos velhos possuía todas as qualidades necessárias a um jesuíta: humildade, capacidade de união e sujeição, mortificação e desprezo, enfim, eram amigos da sua vocação. Enquanto uma ínfima minoria de cristãos velhos - inovadores - quatro ou cinco, e todos os conversos eram inimigos da cruz de Cristo, ou seja, da penitência, mortificação, rigor e sujeição. Mas eram amigos ou que morriam por honra, liberdade e regalo.

Suplicavam ao monarca, dizia Alonso Sánchez, que observasse estes dois grupos acima descritos:

"Ultimamente, disse o Padre Sánchez, se suplica a Vossa Majestade note as duas partes que concorrem aqui. De uma está a eleição que Deus fez de Inácio e o que lhe comunicou e inspirou, a aprovação da Sé Apostólica e dos Papas até agora, a autoridade do Santo Concílio Tridentino, a sucessão de todos os Gerais e Congregações Gerais também, os grandes efeitos que tem feito no mundo, não o que estes perdidos inovam, senão o que Deus e aqueles santos primeiros fundadores, o corpo 
todo da Companhia, e nele todos os cristãos velhos, e o que mais é, os bons, os humildes, os amigos da união e sujeição, mortificação e desprezo, enfim, amigos de sua vocação. Ponha isto em uma balança, e depois, em outra quatro ou cinco (que muito poucos são), e esses confessos, inimigos da cruz de Cristo, quero dizer, da penitência, mortificação, rigor, e sujeição e amigos, ou morrem por honra, liberdade e regalo." 513 .

A existência de sérios conflitos e rivalidades entre os cristãos velhos e novos da Companhia de Jesus foi, nesta carta, exposta com toda clareza possível. A missiva evidenciou também o envolvimento nestes conflitos de membros da corte de Felipe II e do próprio monarca.

\section{GIL GONZÁLEZ DÁVILA CONTRA OS CRISTÃOS NOVOS}

Em 24 de abril de 1593 o padre Gil González Dávila, da Província de Toledo, escreveu para o Vigário Geral, Cláudio Acquaviva, tratando da presença dos cristãos novos na Companhia de Jesus. Informou-lhe que o padre Alonso Sánchez assegurou à Inquisição espanhola que a Quinta Congregação Geral da Companhia de Jesus iria excluir os cristãos novos porque eles foram os autores dos memoriais que maltratavam muito a Ordem.

O padre Gil González Dávila assegurou ao Prepósito Geral que, quando esteve em Roma, era simpatizante dos cristãos novos, por ver que o padre Inácio de Loyola os estimava por serem bons e fiéis. Inclusive, dizia Dávila, não havia exame de ascendência dos postulantes. Entretanto, escreveu Gil González Dávila, depois de comporem vários e ambiciosos memoriais, era necessário tomar uma atitude prática - atitude prática entenda-se: excluí-los ${ }^{514}$ - porque, continuou o jesuíta, ele sabia

\footnotetext{
${ }^{513}$ De Comissario, f. 205 e seg. Citado pro Astrain, Antonio. Op. cit., p. 544.

514 "O padre Alonso Sánchez tem tratado com a Inquisição e outros senhores, de que a Companhia, vendo-se tão maltratada pelos autores modernos [cristãos novos] não poderá deixar de dar ordem no que toca a eles
} 
das amarguras e tentações que a Companhia sofreu graças a problemas bem menores causados pelos conversos. Em outras palavras, os padres Gil González Dávila e Alonso Sánchez estavam culpando os cristãos novos pelos atritos existentes entre a Companhia e a Inquisição da Espanha. Mesmo discurso do marquês de Velada.

Santo Ofício da Inquisição, nobreza, Vigário Geral e jesuítas espanhóis unidos contra os cristãos novos inacianos.

\section{A CONGREGAÇÃO PROVINCIAL DE TOLEDO APROVOU O ESTATUTO}

\section{DE LIMPEZA DE SANGUE}

A Companhia de Jesus tinha em Toledo, sede do arcebispado primaz da Espanha, uma Província. Na véspera da Quinta Congregação Geral foi realizada a Congregação daquela Província. As deliberações seriam levadas para a Congregação Geral. Entre os temas discutidos e votados estava a admissão dos cristãos novos. Aprovou-se que eles não deviam ser admitidos na Companhia de Jesus ${ }^{515}$. Portanto, mais uma força política considerável contra o recebimento dos conversos: Toledo, o arcebispado mais tradicional e influente da Espanha.

\section{“PRISÃO” DE JOSÉ DE ACOSTA}

Ao saber da aversão que determinados jesuítas cristãos velhos sentiam em relação ao cristão novo da Companhia José de Acosta - como foi o caso, anteriormente mencionado, do padre Alonso Sánchez - o Prepósito Geral da

nesta Congregação... É certo que no tempo que eu ai [em Roma] estive, favoreci sua causa por haver visto ser nosso Padre Inácio deste parecer e por ver quantos haviam na Companhia, homens bons e fiéis entre eles, que são mais do que parece. Porque temos vivido em nossa simplicidade e estimado a cada um por suas obras, não fazendo exame. Agora que é visto tanto memorial, tanto ambicioso desta gente, vejo que convém mirar pelo remédio. Mas eu pensava, que esta é uma das coisas que se há de fazer e não dizer-se, nem fazer rumor, porque sei quantas amarguras y tentações tem causado la sé sombra deste negócio em outros tempos e inclusive no precursor de V. Paternidade. Ver Rey, Eusébio. Op. cit. p. 193 e Astrain, Antonio. Op. cit., pp. 592-93.

${ }^{515}$ Ver a respeito Rey, Eusébio. Op. cit. p. 193 
Companhia, Cláudio Acquaviva, o enviou, no início de 1593, para a casa dos Penitenciários de São Pedro ${ }^{516}$.

A Casa dos Penitenciários era um lugar para punir os indisciplinados da Companhia de Jesus. Entretanto, o padre José de Acosta reagiu à punição. Recorreu ao Papa e ao Duque de Sesa. Escreveu ainda para a Espanha reclamando que os superiores abriam suas cartas e que seus irmãos não o respeitavam. O padre Alonso Sánchez informou ao Geral Acquaviva sobre o conteúdo das cartas do cristão novo José de Acosta. O Prepósito Geral respondeu dizendo que já havia proibido a abertura das cartas enviadas pelo rei da Espanha ou por seus ministros para o padre José de Acosta. Negou que ele, José de Acosta, tivesse o direito à isenção ${ }^{517}$, como ele queria. Quanto ao tratamento recebido na Casa dos Penitenciários disse que havia ordenado que conversassem e o tratassem com caridade. Entretanto, reconhecia que seria praticamente impossível que, depois do que ele fez e continuava fazendo, como por exemplo, comer com grandes personagens, visitar estações em carroças com seculares, sair da casa em carro e semear cizânia entre os súditos e o Padre Geral, fosse visto com bons olhos ${ }^{518}$.

Houve, inclusive, rumores de que o Vigário Geral Cláudio Acquaviva estaria abrindo um processo para impedir a participação do padre José de Acosta na Quinta Congregação Geral. Ao ser comunicado a respeito, o Duque de Sesa ${ }^{519}$ informou ao Papa Clemente VIII. O pontífice enviou o padre Toledo - cristão novo - à Casa Professa com ordem para o Geral lhe mostrar o processo. O Geral Cláudio Acquaviva negou a existência do suposto processo, e disse que somente havia ordenado o padre Acosta a obedecer às regras da Companhia de Jesus ${ }^{520}$. Esta atitude do Vigário Geral representou um recuo diante do Papa, do Duque e do padre Toledo.

\footnotetext{
${ }^{516}$ Astrain, Antonio. Op. cit., p. 568.

${ }^{517}$ No caso, isenção de pagar penitência na Casa dos Penitenciários.

${ }^{518}$ Ver Soli Hisp., 1588-1602. Toletana. Epist. Gen., 1588-1600, f. 287. Citado por Astrain, Antonio. Op. cit., p. 568.

${ }^{519}$ Embaixador de Felipe II em Roma.
} 


\section{CLÁUDIO ACQUAVIVA INTENSIFICA SUA CAMPANHA ANTI-SEMITA}

No dia 10 de maio de 1593 o Vigário Geral Cláudio Acquaviva escreveu para o padre Alonso Sánchez - na época seu representante na corte de Madri garantindo-lhe que a Quinta Congregação Geral excluiria os cristãos novos: “o que pede se remedeie dos notados em sua linhagem"521. Isso significou a adesão total e incondicional do Vigário Geral Cláudio Acquaviva, italiano de origem, à causa dos anti-semitas.

Em 24 de agosto de 1593 o Geral Cláudio Acquaviva escreveu para o Papa Clemente VIII falando-lhe a respeito do jesuíta José de Acosta e dos demais cristãos novos da Companhia de Jesus. Dizia que não tinha dúvida de que José de Acosta estava dominado pelo vício da ambição. Inclusive lhe havia pedido para ser Provincial. Quando era visitador, escrevia o Geral, José de Acosta esperava honras da Companhia, em tudo enaltecia ao Geral e respondia asperamente aos inquietos. Por outro lado, tornou-se odioso entre os jesuítas porque, quando estava no exercício da função de visitador, foi amigo do regalo e da honra. Foi à Roma, continuava Cláudio Acquaviva, falar com o Papa sobre a problemática envolvendo a Inquisição espanhola e a Companhia de Jesus sem autorização do seu superior imediato. Entretanto, depois que ocorreu o inevitável, ou seja, a punição na Casa dos Penitenciários de São Pedro, se afastou do padre Geral e se associou aos perturbadores (memorialistas) da Companhia. É sabido que tem procurado o apoio do rei Felipe II e dos inquisidores para excluir os delegados que participariam da Congregação Geral e facilitar a ida daqueles que advogassem suas idéias.

Após esta apresentação, o padre Geral Cláudio Acquaviva revelou ao Pontífice que José de Acosta era cristão novo e que na Congregação a ser realizada seria indispensável resolver a questão da presença dos conversos na Companhia,

\footnotetext{
${ }^{520}$ Simancas, Inquisición, sala 39, 322. Carta del Embajador ao Rey, de 31 de Agosto de 1593. Citada por por Astrain, Antonio. Op. cit., pp. 568-69.
} 
porque o monarca Felipe II e muitos outros espanhóis insistiam que se fechasse a portas para eles. Em decorrência destes motivos, o Geral Cláudio Acquaviva suplicou à Sua Santidade para não permitir que o padre José de Acosta participasse da V Congregação Geral ou que, se assistisse, não tivesse direito a voto definitivo.

A súplica assim formulada não se referiu apenas ao cristão novo José de Acosta, ou seja, o Prepósito Geral da Companhia de Jesus, Cláudio Acquaviva, queria também que o Papa Clemente VIII proibisse a participação de todo e qualquer cristão novo espanhol na V Congregação Geral da Ordem ${ }^{522}$.

Em outras palavras, o padre Geral estava buscando apoio político para boicotar a presença dos cristãos novos na Congregação Geral com o propósito de facilitar a aprovação da exclusão por ele agora desejada e pelo grupo anti-semita.

A resposta do Papa Clemente VIII: concordou que nenhum cristão novo espanhol participasse da Congregação Geral, exceto o padre José de Acosta, inclusive com direito ao voto decisivo, atendendo assim à vontade de Felipe II ${ }^{523}$.

A decisão do Pontífice em relação a padre José de Acosta demonstrou o vínculo estreito que existia entre o referido padre e o rei Felipe II. Pois, apesar da conversa que o padre Alonso Sánchez teve com o monarca espanhol tentando denegrir a imagem do cristão novo e, mesmo após a leitura da carta enviada pelo Geral dizendo que Felipe II e muitos espanhóis seriam favoráveis à exclusão dos cristãos novos da Ordem, Clemente VIII garantiu a participação do cristão novo José de Acosta na Congregação Geral, sem nenhuma restrição. Por outro lado, o Papa, praticamente selou a exclusão dos cristãos novos da Companhia ao aceitar a proposta que impedia a presença dos demais conversos espanhóis na Congregação.

O caso do cristão novo José de Acosta evidencia que os cristãos velhos sentiam grande dificuldade em tolerar o poder e a influência que determinados

\footnotetext{
521 “Aquaviva a Sánchez. Roma, 10 mayo 1593. Tolet. 5/I 296v. Citada por Medina, Francisco de Borja. “Ignacio de Loyola y la Limpieza de Sangre.” Op. cit., p. 613.

522 “De rebus Congregationum, I, II, III, IV et V, n. 78. Citada por por Astrain, Antonio. Op. cit., p. 572.

${ }^{523}$ Conforme Astrain, Antonio. Op. cit., p. 573.
} 
conversos alcançavam sobre as autoridades políticas da época e no interior da própria Companhia de Jesus ${ }^{524}$.

${ }^{524}$ No dia 17 de setembro de 1593 o jesuíta cristão novo Francisco de Toledo recebeu o chapéu cardinálico. Ele foi o primeiro jesuíta a tornar-se cardeal. Esse fato deve ter agravado ainda mais a intolerância dos cristãos velhos em relação aos cristãos novos. Sobre a nomeação ver O’Neill, Charles E., S. I. e Domínguez, Joaquín Ma , S. I. Op., cit., Vol.IV. p. 4093. 


\section{CAPÍTULO IX. OS "EXCLUÍDOS”. VENCERAM OS ANTI-SEMITAS}

No dia 3 de novembro de 1593 teve inicio a Quinta Congregação Geral da Companhia de Jesus. Como já foi mencionado, a participação dos cristãos novos ficou restrita ao padre José de Acosta. Pelo que foi visto até este momento, praticamente todos os delegados eram favoráveis à exclusão dos conversos.

Como já havia ocorrido com o jesuíta português Francisco Teófilo e, de certo modo, com o também português Fernando Rebello, o inaciano espanhol Miguel Marcos, agora na Congregação Geral, interferiu na discussão sobre a presença e exclusão dos cristãos novos. Ele disse que tinha absoluta certeza de que, entre os vinte e sete autores dos memoriais, vinte cinco eram de linhagem de judeus, e que dos outros dois restantes, duvidava de $u^{525}$.

\section{PEDRO DE RIBADENEIRA E SUA LUTA INGLÓRIA}

Entretanto, houve uma voz influente a favor dos cristãos novos. Trata-se do também cristão novo espanhol Pedro de Ribadeneira, jesuíta de grande importância na história da Companhia de Jesus, historiador e teólogo renomado.

Ele elaborou uma argumentação exaustiva contra a exclusão dos cristãos novos. Foram treze razões ao todo, as quais serão transcritas na íntegra devido à importância histórica desta defesa, a qual fez um resgate do passado da Companhia de Jesus em sua relação com os conversos, ao mesmo tempo em que demonstrou a paixão que o padre Pedro de Ribadeneira sentia por seus semelhantes, ou melhor, por aqueles que tinham os mesmos antepassados que os seus. Esta defesa expressou o sentimento que os cristãos novos cultivavam entre si, a dedicação com a qual

\footnotetext{
${ }^{525}$ Valpedroso, Diario. Citada por por Astrain, Antonio. Op. cit., p. 593.
} 
desempenhavam as tarefas que lhes eram atribuídas e o alto grau de excelência que muitos deles alcançaram na Companhia de Jesus.

“As Razões que se me Oferecem para não Fazer Novidade no Admitir Gente na Companhia”:

“A 1. a porque é contra nossas Constituições, as quais não excluíam aos tais, nem punham por impedimento essencial nem secundário ser de tal ou tal geração;

A 2. ${ }^{a}$ porque é diretamente contra o espírito e sentimento de N. P. ${ }^{\mathrm{e}}$ Inácio, o qual muitas vezes foi importunado acerca disto pelo Padre Araoz, e sempre respondeu que não era conforme o espírito de Deus nem coisa que convinha à Companhia. E no ano de 1560, quando o Padre Laínez, sendo Geral, enviou ao Padre Nadal por visitador à Espanha, eu lhe dei as cartas de Araoz para N. P. ${ }^{\mathrm{e}}$ sobre este assunto, e as respostas do

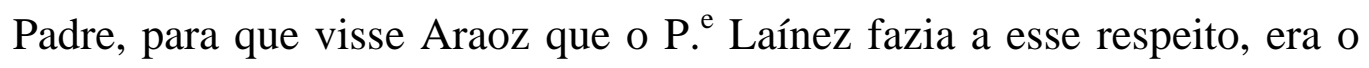
mesmo que havia feito antes nosso santo Padre; e estas respostas se acharão nos registros das cartas daquele tempo, se se buscam com atenção. Também, é contra o espírito do nosso Padre, porque eu o ouvi dizer diante de muitos e com lágrimas nos olhos, e desde aquele tempo o tenho notado como coisa rara, e que nos causou admiração, que houvera tido por grande mercê de Deus ele haver nascido de judeus; e acrescentou a causa com estas palavras: Como! Poder ser parente de Cristo nosso Redentor segundo a carne, e da gloriosa Virgem Maria nossa Senhora! E um cavaleiro biscainho, que se chamava Pedro de Carate (do qual recordaram os Padres antigos de Roma, porque pousou em nossa Casa da Torre Roxa, e foi grande amigo do nosso Padre), me disse que N. P. ${ }^{e}$ lhe havia dito isto mesmo, e que lhe havia dado tantas razões para isso, que lhe havia persuadido a desejar ser descendente de judeus, apesar de ser coisa tão contrária ao natural dos biscainhos, e que ele antes tanto 
aborrecia. E o Padre Everardo Mercuriano, depois que lhe elegemos Geral, nos contou um dia sobre mesa, que Alex. ${ }^{0}$ de Foligni, pai do padre Fr. Alex. ${ }^{0}$, P. ${ }^{\text {e }}$ da ordem de S. ${ }^{\text {to }}$ Domingo (o qual está em Roma, e havendo sido antes judeu, se tornou cristão com seu pai), em sua presença e de outros muitos que diziam que era infâmia ser de linhagem de judeus, havia dito: eu fora desta opinião, se não obstara a autoridade do Padre Inácio, que me disse que tivera por mercê de Deus haver nascido desta linhagem.”

A 3. a , porque é contra o espírito e juízo do Padre Mestre Laínez, varão tão santo e tão sábio e tão benemérito da Companhia, ao qual, sendo Geral e seguindo o espírito do seu santo Padre Inácio, em uma carta de 19 de novembro de 1560, escrevendo ao Padre Araoz que insistia a esse respeito lhe disse: Nunca permita nosso Senhor que nem o favor dos reis, nem as visitas ativas ou passivas de grandes, nem o humor ou erro nacional, nem a altivez do próprio juízo e sentimento, nem o asco ou desprezo da alheia carne, como se fosse de outro metal a sua, ou por outro Deus criada sua alma, lhe obscureçam ou percam o conhecimento, que há de ter um não fingido religioso, da união e respeito que deve a seus superiores, mesmo que fossem (como dizem), um pau; e da circunspecção em não soltar contra eles a língua e dar ocasião aos que ouvem, ou de escandalizar pelo pouco temor de Deus de quem fala, ou de amotinar-se deixando a união com sua cabeça e seguindo a quem frustra inflatur in sensu cordis sui, ${ }^{526}$ privado de sua cabeça e do divino influxo, que por ela vem. De onde nasce que um diga; Ego sum Pauli ${ }^{527}$ e murmure de linhagem, e outros ao contrário; e que um diga ao menos com as obras:

\footnotetext{
${ }^{526}$ Conforme Epístola do Apóstolo Paulo aos Colosssenses II, 18: "Ninguém vos domine a seu belprazer com pretexto de humildade e culto dos anjos, metendo-se em coisas que não viu; estando debalde inchado na sua carnal compreensão."

${ }^{527}$ Conforme Primeira Epístola do Apóstolo Paulo aos Coríntios, I, 12: “Quero dezer com isto, que cada um de vós diz: Eu sou de Paulo; e, Eu de Apolo; e, Eu de Cefas; e, Eu de Cristo.”
} 
Deus est, Deus tantum gentium, e outro est Deus tantum iudaeorum, ${ }^{528}$ cum tamen idem site dominuns nomnium, diues in omnes qui qui inuocant eum, ${ }^{529} \ldots$ E por isto, os que conhecem estas verdades, creio que tomam melhor caminho escudando-se com elas, para vencer e burlar-se das vãs opiniões e erros e paixões contrárias do mundo, que os que por não mudar o mundo, se configuram a ele, e por satisfazê-lo e ir adiante dele a cabeça descoberta, afligem os inocentes, e cerram-lhes de sua parte os ordinários caminhos da perfeição e paz evangélica. Porém espero em nosso S. ${ }^{\text {r }}$, morto por todos e salvador de todos, que não prevalecerá isto em sua mínima Companhia, senão que por ele dizer do mundo não deixaremos de guardar nosso. Instituto; o qual seguindo, idem dicemus omnes, et nom erunt in nobis schismata ${ }^{530}$ et Dominus conteret Sathan sub pedibus nris. ${ }^{531}$

E em outra carta de 23 de novembro de 1564 respondeu também ao mesmo Padre Araoz acerca disto estas palavras: Quanto ao aceitar pessoas com nota, por aqui não se aceitam pessoas que tenham nota segundo a lei de Deus ou canónica; nas que têm nota segundo as imaginações, parece que basta guardar-se ou moderar-se nas terras onde reinam os tais humores ad duriciam cordis eorum; ${ }^{.32}$ onde não reinam, não há para que impedir o bem dos que entram, e dos que são por eles ajudados, pois in omni gente qui timet Deum, et operatur iustitiam, acceptus est Domino, ${ }^{533}$ e conforme a isto por aqui se procede, y creio nosso $S .^{\text {or }}$ se serve dele.

\footnotetext{
${ }^{528}$ Conf. Epístola do Apóstolo Paulo aos Romanos III, 29: "É porventura Deus somente dos judeus? E não o é também dos gentios? Também dos gentios, certamente."

${ }^{529}$ Conf. Epístola do Apóstolo Paulo aos Romanos, X, 12: "Portanto não há difereança entre judeu e grego; porqeu um mesmo é o Senhor de todos, rico para com todos os que o invocam."

${ }_{530}$ Conf. Primeira Epístola do Apóstolo Paulo aos Coríntios, I, 10: "Rogo-vos, porém, irmãos, pelo nome de nosso Senhor Jesus Cristo, que digais todos uma mesma coisa, e que não haja entre vós dissensões; antes sejais unidos em um mesmo sentido e em um mesmo parecer."

${ }^{531}$ Conf. Epístola do Apóstolo Paulo aos Romanos, XVI, 20: "E o Deus de paz esmagará em breve Satanás debaixo dos vossos pés."

${ }^{532}$ Conf. Evangelho de Mateus, XIX, 8: "Disse-lhe ele: Moisés por causa da dureza dos vossos corações.

${ }^{533}$ Atos dos Apóstolos, X, 35: Mas que lhe é agradável aquele que, em qualquer nação, o teme e obra o que é justo.”
} 
A 4. ${ }^{\text {a }}$, porque é contra o espírito e uso do Padre Francisco de Borja, o qual, por ser varão ilustríssimo e tão experimentado nas coisas da Espanha, foi ainda mais fácil em receber a esta gente que os Padres Mestre Inácio e Mestre Laínez. E contando-me o mesmo Padre um dia que Rui Gomes lhe havia dito que como a Companhia recebia os tais, me disse que o havia respondido: como o rei tem em seu serviço a fulano e a fulano, que são desta linhagem? Pois se sua Majestade não considera isso nos que admite para seu serviço, e põe em sua casa; quereis vós que o considere eu para admiti-los na casa de Deus e ao serviço daquele Senhor, apud quem non est acceptio personarum neque distinctio iudaei et graeci, neque barbarus neque scytha? ${ }^{534}$

A 5. a , por ser contra o uso e prática de toda a Companhia até agora, e contra o parecer do mesmo P. ${ }^{e} \mathrm{~N}$. Cláudio Acquaviva, e haver-se visto que Deus se há servido disso; e a Companhia tem tido união entre si e lustre e bom nome com os de fora, e não é justo alterar as obras de Deus, e perverter sem causa o que santamente está estabelecido.

A 6. ${ }^{a}$, porque não há motivo para fazer mudança, nem a que se alega dos perturbadores é verdadeira, nem bastante para fazer-se; não é verdadeira, porque não se pode dizer que por ser eles de tal sangue ou linhagem têm perturbado a Companhia. O primeiro, porque outros tem havido sabemos que têm tido mão nestes negócios, os quais são tidos por limpos em Castela e Portugal, como Abreu que tem sido o capitão de todos e N. e H. e outros; de sorte que não se pode dizer com verdade que é vício de linhagem, senão das pessoas; pois homens de várias linhagens concorrido nesta turbação. O segundo, porque muitos que por ventura são desta linhagem (embora eu não saiba que o seja algum), são e se têm mostrado muito fiéis e verdadeiros filhos de nosso Padre e da Companhia,

${ }^{534}$ Conf. Epístola do Apóstolo Paulo aos Romanos, II, 11: "Porque, para com Deus, não há acepção de pessoas." 
e se o vício estivera na natureza, estes também seguiram os demais. $\mathrm{O}$ terceiro, porque no tempo de N. P. ${ }^{\mathrm{e}}$ Inácio houve outra borrasca, e ainda mais perigosa que esta, em Portugal e por ela se saíram e foram afastados muitos da Companhia, e não atribuiu nosso Padre Inácio aquela turbação à linhagem nem eles eram tais. E no tempo do Padre Laínez sucedeu outro alvoroço bem perigoso, e se uniu em grande trabalho a Companhia, e dele foram autores um espanhol e dois franceses e um italiano, e entre eles dois dos dez primeiros Padres da Companhia, e não eram desta linhagem. No tempo do Padre Francisco, digo sendo comissário geral, ele padeceu muito, e se viu muito afligido e a Companhia em sua pessoa, por ser tão principal; e ele que diziam que era autor desta tribulação não era de sangue de judeus, senão a seu parecer mais limpo que o sol. No tempo do Padre Everardo, já sabemos os memoriais que deram ao Papa contra ele e seu governo, e que os que os deram eram italianos, e o que nisto se fez em o que há parado. Assim que, não há que maravilhar-se do que se tem feito, nem... pois em todo tempo tem havido trabalho, e lhe tem dado homens de diferentes nações e linhagens. Porém fosse verdade, não era motivo suficiente para fazer-se novidade nisto. O primeiro, porque não é justo que poucos reinos padeçam muito que não tenham culpa, nem que se tenha mais conta com os que contradisseram a Companhia, que com os que a defenderam, nem com os poucos que alvoroçaram, que com os muitos que sossegaram. O segundo, porque se miramos os princípios, progresso, propagação e fruto da Companhia, e as pessoas que nosso Senhor tem tomado por instrumento para obrar o que tem obrado, acharemos que entre os homens mais insignes em sua santidade, letras, prudência e raros dons da Companhia, alguns têm havido desta linhagem, e que Deus tem mostrado que não tem conta com o sangue que tomamos de nossos pais, senão com o que Ele derramou por nós na cruz ... E se vemos que na Itália o Padre Juan Batista Romano, com haver sido antes 
judeu e entrado já adulto na Companhia, foi servo de Deus e trabalhou e padeceu muito pela Companhia e pela Igreja de Deus, e que foi enviado por dois papas ao Oriente, sabendo que por seus pés se havia vindo à pia; e Fr. Alexandre na ordem de $S .^{\text {to }}$ Domingos hoje em dia é tão grande predicador e de tanta autoridade, e que não o impedi de haver sido antes judeu e de pais judeus, por que na Espanha se há de ter tanta conta com os que vêem desta linhagem, estando já purgada a culpa que tiveram seus avós com o decurso de tantos anos e com a bondade de seus filhos?

Daqui segue a 7. a razão, que isto é contra a honra da Companhia da Espanha e ainda de toda a nação espanhola: a qual, ou se há de ter toda por judia e marrana, como a chamam na Itália, ou por tonta e louca; por judia, se existe motivo para fazer estatutos e diferenças de linhagem, pois em nenhuma outra nação, mesmo entre os que hoje vivem como judeus e têm suas sinagogas, há esta diferença; e sabemos que inclusive no colégio dos cardeais tem havido em nossos dias pessoas que descendem desta linhagem, aos quais em algumas igrejas da Espanha não deram uma capelania, com haver já cem anos que não há judeus nos reinos de Castela; por loucos e desbaratados, se sem necessidade se desonra e afronta.

La 8. ${ }^{\text {a }}$, se pretendemos unir a Companhia e soldar nossas quebras e apagar este incêndio que o demónio tem levantado, pensamos que será bom meio o desuni-la e despedaçá-la mais, e fazer que não haja irmão que mire com bons olhos a seu irmão, senão como a inimigo e como a homem de outra casta e seita, e lançar azeite no fogo para que se acenda mais, abrase e consuma a toda a Companhia? Que sensatez seria esta? Que pecado? Que ofensa de Deus e que dano tão prejudicial e irreparável? E se o P. ${ }^{\mathrm{e}}$ Geral agora tem alguns Padres queixosos pela aridez com que lhes parece que seu Padre lhos há tratado, quanto mais seriam os que se tentariam e afligiriam e por ventura se fariam de filhos fiéis inimigos 
cruéis? Outra vez, de só imaginar-se que um Padre teria este humor e tratava desta matéria, houve na Espanha grande alvoroço e desassossego, e não se aplacou até que o próprio Padre desenganou aos que isto pensavam, mostrando que não pretendia novidade, nem lhe parecia bem que a houvesse acerca disto na Companhia.

A 9. a , isto é contra o parecer dos homens mais santos, mais religiosos, mais graves e amigos da Companhia. Mais santos, porque o $\mathrm{P} .{ }^{\mathrm{e}}$ Mestre Ávila disse que por duas coisas se poderiam perder a Companhia; a primeira, por admitir a ela muita turba; e a 2. a por fazer distinção de linhagem e sangue. Mais religiosos, porque os que o são mais, e mais amigos da Companhia, enaltecem sumamente o que ela faz, e dizem claramente que em fazendo estatuto, se perderá, porque entrará o fogo da discórdia nela, a divisão e a guerra doméstica e entranhável; como existe em outras religiões que têm estatuto. Os mais graves e amigos, porque a mim mesmo me têm dito, dando-lhes eu razão do que ordenam nossas Constituições e usa a Companhia, dizendo-me que embora para os ofícios de inquisição seja necessário, e para os outros conselhos, colégios e igrejas seculares isto se pode por ventura em alguma maneira tolerar, porém que para as religiões, que professam menosprezo do mundo e perfeita imitação de Cristo lhes parece muito mal, e que, se Sto. Tomás não quer que o recém-convertido pense muito se entrará na religião, quando Deus lhe chama, muito menos a religião deve rechaçar ao que chama Deus, por nascer de avós ou de bisavós, que agora cem ou duzentos anos se converteram. E falando eu com o Cardeal de Toledo e inquisidor geral, e dando-lhe as razões que tem a Companhia para desejar que o santo Ofício não a ocupe no ofício de consultores, embora sempre esteja aparelhada para obedecer, lhe disse que agora vivíamos em paz, e que havendo consultores, poderia ser que se turbasse, porque, como os que o hão de ser, hão de ter certa qualidade de sangue e limpeza, se se 
lança mão de alguns que a tem e não tantas letras e prudência, deixando aos que são avantajados nisto, por não ser tão limpos, haveria comentário e causaria divisão etc; me disse que tinha razão. E outras pessoas graves o hão aprovado, ... e inclusive porque um cavaleiro, nosso amigo, havia dito ao cardeal de Toledo que um judeu entre outros era ele que turbava a Companhia, pensando o cardeal que isso ocorria na Companhia, preocupado, me perguntou: É esta linguagem da Companhia?

A 10. ${ }^{\text {a }}$, muitos duvidam se estes estatutos, como se usam, são lícitos; outros, se são expedientes; outros dizem que se cometem graves pecados; outros, que são grande tentação de vinganças, ambições e invejas e agravos entre os religiosos, e um fogo que lhes abrasa e consome, e que por isto algumas religiões, que os haviam impetrado da Sede Apostólica, se tem arrependido e lhes tem feito revogar ou que não os guardam. Pois, para que a Companhia se há de pôr nestes labirintos e dificuldades? Das quais não poderá sair sem dano e escândalo de muitos, e sem sua autoridade e boa opinião, com a qual agora edifica e pacifica e repreende o que convém neste negócio, quando e como é necessário.

A 11. a, havendo até agora N. P. Geral seguido nisto o espírito dos outros Gerais seus antepassados, se agora muda-se, que pareceria ao mundo, senão que é vingança? E que a desobediência ou mal término de um lhe tem vencido e irritado de maneira que lhe tem feito mudar de parecer, e que não há tido virtude para resistir a tão duro golpe? Pelo qual ficaria menosprezada sua autoridade e a opinião, que todos com tanta razão da pessoas de sua

12. a . A morte do Padre Alonso Sámchez[!] em tal ocasião e tempo, tem dado muito que pensar e que dizer; e os que mais sabem de suas coisas, dizem que tem sido do céu e em grande benefício da Companhia, pelo mal espírito que tinha nisto: e inclusive acrescentam que tem sido castigo de Deus, por haver falado desta matéria nas informações que se 
deram na Congregação Provincial, mais do que convinha, e que então se semeou uma cizânia e mal semente, que para que não cresça e se arraigue, não há outro melhor remédio senão enterrá-la com perpétuo silêncio e esquecimento. Deixo outras razões, que cada homem sensato e prudente por se mesmo as poderá entender, embora eu não as diga.

13. ․ Porém entre elas é uma e não pequena consideração, que se se prejudicar e se romper uma vez nosso Instituto em coisa tão substancial e de tanta importância, e se fizesse decreto tão contrário ao espírito de nossos santos Padres Inácio, Laínez e Francisco, e contra o uso Companhia, com o qual pela misericórdia de Deus ela tem tanto florescido; fica aberta a porta para enfraquecer e tocar todas as demais coisas substanciais do mesmo Instituto; porque é certo que não há nenhuma (excetuando as que são essenciais e contra nossos votos) que seja tão substancial, como esta, porque esta toca a paz, a união, a caridade, que é a vida e a alma da religião e o fim imaculado dela; e o dilatar-se as profissões, o poder despedir, o ser Geral perpétuo, o fazer superiores por sua mão e não por eleição dos súditos, e outras coisas semelhantes; são meios que se tomam para conseguir melhor este fim; e assim tanto mais cuidado se deve pôr em guardar e defender que nelas outras coisas que não são tão substanciais, quanto importa mais o fim que os meios.”.535.

É compreensível que, para cumprir seu papel de defensor dos cristãos novos, Pedro de Ribadeneira tenha omitido alguns acontecimentos relevantes concernentes aos conversos na Companhia de Jesus.

É verdade que as Constituições aprovadas em 1558 não excluíam os cristãos novos, do mesmo modo é verdade que - apesar de não constar nenhuma forma de

\footnotetext{
535 Patris Petri de Ribadeneira. Societatis Jesu Sacerdotis. Confessione, Epistolae Aliaque Scripta Inedita. Tomus Secundus. Matrit. 1923, pp. $374-84$.
} 
impedimento, seja essencial ou secundário - o postulante devia declarar se tinha ou não ascendência judaica.

Quando ele disse que a exclusão seria contra o espírito e sentimento do fundador da Companhia, Inácio de Loyola, desconsiderou o caso do conflito com o Arcebispo de Toledo, Juan Martínez Silíceo, no qual Inácio de Loyola resolveu aceitar, graças a um provável acordo de cooperação celebrado entre ambos, a exclusão dos cristãos novos da Arquidiocese e de toda a Espanha.

Pedro de Ribadeneira entendeu que o estatuto seria contra o uso e a prática de toda a Companhia. Não era exatamente assim. Em 1575 a Província de Goa já havia decidido que não receberia mais os cristãos novos. Também não seria, como ele acreditava, contra o parecer do Vigário Geral Cláudio Acquaviva. Já foi visto que desde 1590 ele já havia se posicionado a favor da exclusão dos conversos, inclusive proibiu, naquele mesmo ano, que fossem recebidos em toda Espanha.

Ele afirmou que o estatuto seria contra a honra da Companhia da Espanha e de toda a nação espanhola. Ele fez esta afirmação ao comparar com as demais nações que não possuíam estatutos de limpeza de sangue. Mas se ele considerasse os valores internos à nação espanhola, constataria exatamente o contrário, ou seja, que o maior motivo de honra da nação espanhola naquele período era exatamente a noção de pureza de sangue. Portanto, a presença de cristãos novos na Companhia de Jesus da Espanha a desonraria. Albert Sicroff considerou a relação ente a limpeza de sangue, a religião e a nacionalidade espanholas nos seguintes termos: "o princípio de limpeza de sangue se havia convertido numa espécie de dogma da religião e da nacionalidade espanholas”536. No que se refere às correlações existentes entre a limpeza de sangue, a nobreza e honra espanholas, ele disse o seguinte:

“O valor da limpeza de sangue, que chegou a ter uma importância crucial para os espanhóis desde meados do século XVI em diante, se acha

\footnotetext{
${ }^{536}$ Sicroff, Albert. Op. cit., p. 216.
} 
em estreita relação com os valores da nobreza e da honra, cuja importância aumentou também até final do mesmo século.”537.

Houve momentos em que o padre Pedro de Ribadeneira chegou a ser ingênuo. Pensou que seria capaz de inverter, ou no mínimo, anular a aversão dos cristãos velhos em relação aos cristãos novos apelando para os princípios religiosos da paz, união e caridade. Ou seja, ele acreditava que a aprovação do estatuto de limpeza de sangue desuniria e despedaçaria ainda mais a Companhia. O mais provável, diante das circunstâncias, era que a reprovação do estatuto de limpeza de sangue se tornasse em mais um motivo para acirrar a intolerância dos cristãos velhos com os novos.

Seu apelo à morte do padre Alonso Sánchez, por motivos supostamente transcendentais, um castigo divino por ser favorável ao Estatuto de Limpeza de Sangue, pode ter sido considerado pelos anti-semitas uma atitude desesperada do cristão novo.

Afirmou que os homens mais eminentes e os grandes amigos da Companhia eram contrários à adoção do Estatuto de Limpeza de Sangue. Entretanto, o único que se pode afirmar, com relativa certeza, que se manifestou contra a exclusão dos cristãos novos foi o padre Mestre Ávila, provável cristão novo.

Pedro de Ribadeneira disse que a Companhia de Jesus gozava de reputação e honra, o que não deixa de ser verdade. Mas ele ignorou a crise que a Ordem estava passando devido ao problema, exatamente, dos conversos.

Por outro lado, estas omissões não anulam o mérito do padre Pedro de Ribadeneira na defesa dos cristãos novos jesuítas. Ele negou, com veemência, a principal acusação que naquele momento recaiu sobre os conversos: a de serem os autores dos memoriais. Afirmou que o sangue ou a linhagem não era motivo para perturbar a Companhia e que, sendo assim, as perturbações que vinham ocorrendo não eram um vício de linhagem, e sim de pessoas, e que o único sangue que Deus

537 Sicroff, Albert. Op. cit., p. 336. 
considerava era o que ele havia derramado na cruz por nós, e não o dos antepassados. Este ponto da sua defesa confirmou o sentimento anti-semita que prevalecia na Companhia de Jesus no final dos anos oitenta e início dos noventa do século XVI.

Pedro de Ribadeneira foi fiel aos fatos históricos ao constatar que os cristãos novos não participaram dos transtornos causados à Companhia, como ocorreu, por exemplo, na Província portuguesa quando era Provincial o padre Simão Rodrigues.

Sua afirmação de que alguns dos cristãos novos encontravam-se entre os jesuítas mais eminentes da Companhia de Jesus estava comprovada pelos fatos históricos. Entre eles citam-se, por exemplo, Juan Alfonso de Polanco, Diego Laínez, Henrique Henriques e o próprio José de Acosta.

As passagens bíblicas que citou têm um significado inequívoco: a adoção do estatuto de limpeza de sangue pela Companhia de Jesus contradiria, frontalmente, o pensamento do apóstolo Paulo.

A referência à tolerância de São Tomás de Aquino foi oportuna, já que ele era a grande referência teológica da Companhia de Jesus.

É provável que, como disse Pedro de Ribadeneira, algumas religiões ou revogaram seus estatutos de limpeza de sangue ou não os aplicavam. Pois foi exatamente no mesmo ano em que ele redigiu a defesa dos cristãos novos jesuítas, 1593, que o converso Francisco de Toledo S. J. foi promovido a cardeal.

\section{A TOLERÂNCIA DE MIGUEL DE TORRES}

O padre Pedro de Ribadeneira não era o único jesuíta contrário às mudanças previstas nas Constituições. Apesar de ter sido a favor da exclusão dos cristãos novos nos anos setenta, o padre Miguel de Torres escreveu para os delegados da Quinta Congregação Geral posicionando-se contra toda e qualquer modificação nas Constituições: "para que, fundados sobre tão firme e valoroso fundamento, sem 
desviar-se dele nem no alto nem no baixo, nem em pequeno nem em grande, tudo o que tratarem e determinarem lhes suceda prosperamente. ${ }^{\text {,538. }}$.

O que poderia ter ocorrido para fazer com que o padre Miguel de Torres mudasse de opinião? Ele estava completamente afastado da vida religiosa, vivendo recluso na Casa Professa de Toledo. Devido à sua idade avançada, oitenta e seis anos, nem sequer pôde participar da Congregação Provincial de Alcalá. Supõe-se que em função de tais condições, Miguel de Torres não almejasse mais nenhuma forma de poder na Companhia de Jesus. Portanto, não tinha mais rivais, nem cultivava invejas, intolerância ou preconceitos. Tampouco não se sentia mais na obrigação de agradar aos demais, senão à sua consciência ${ }^{539}$.

\section{A APROVAÇÃO DO ESTATUTO DE LIMPEZA DE SANGUE}

No dia 23 de dezembro de 1593, antevéspera do natal e último dia de atividade da Congregação antes do final daquele ano, foi votado o Estatuto de Limpeza de Sangue da Companhia de Jesus. Tomou a palavra o jesuíta espanhol Melchor (Miguel) Marcos. Acusou os conversos de serem os autores dos memoriais. Afirmou, dizendo ter absoluta certeza, de que entre os vinte e sete que compuseram os memoriais, vinte e cinco eram da linhagem de judeus e que em relação aos dois restantes, duvidava da ascendência de um deles ${ }^{540}$.

Entretanto, em um dos memoriais, assinado pelo padre Miguel de Medina, criticou-se a presença dos cristãos novos no governo da Companhia: "por mandar gente não limpa, são os limpos e nobres maltratados, dissimulando-se com paixão agravos de uns, e com a mesma castigando-se outros que não são tão grandes”. Ou seja, os cristãos novos, quando no poder, favoreceriam os conversos, eram parciais e

\footnotetext{
${ }^{538}$ Epist. Hisp. XXXI, B., f. 52. Citada por por Astrain, Antonio. Op. cit., p. 578.

${ }^{539}$ A carta de Miguel de Torres S. J. foi escrita em 05 de agosto de 1593. No dia 24 de outubro do mesmo ano expirou em Toledo. Ver Astrain, Antonio. Op. cit., p. 578.

${ }^{540}$ O Jesuíta James W. Reites disse que era impossível provar se os autores do mermorias eram cristãos novos. Reites, W. James, S. J. "Ignatius of Loyola and the Jews". In Studies in the Spirituality of Jesuits. Vol. XIII, N. ${ }^{\circ}$ 4, September, 1981, p. 31. Ver também, Astrain, António. Idem, p. 593 e Medina, Francisco de Borja. "Ignacio de Loyola y la Limpieza de Sangre.” Op. cit., p. 610.
} 
tendenciosos, portanto injustos. Foi o que quis dizer o cristão velho Miguel de Medina.

Se a maioria dos autores dos memoriais era realmente de cristãos novos, é forçoso deduzir que eles foram muito ingênuos em acreditar que poderiam mudar a forma pela qual a Companhia de Jesus estava organizada e administrada. Além de ser uma minoria, os cristãos novos estavam cientes de que eles deviam ter muita cautela em tudo que faziam ou diziam, pois os cristãos velhos estavam atentos a todos os seus passos. Portanto, em função da experiência adquirida, é muito pouco provável que os memoriais tenham sido escritos pelos cristãos novos espanhóis.

Estava dado o último passo para a aprovação do Estatuto. O argumento era poderosíssimo. Colocou os cristãos novos contra o Vigário Geral e toda a estrutura organizacional da Companhia de Jesus, a qual era considerada uma das principais causas da breve, mas vitoriosa, história da Ordem. A hierarquia e a obediência teriam sido questionadas em seus fundamentos pelos memorialistas. Não poderia haver acusações mais graves contra um jesuíta.

O decreto 52 da Quinta Congregação Geral da Companhia de Jesus excluiu os cristãos novos nos seguintes termos:

“Os ministérios que a Companhia exercita para procurar a salvação universal das almas são tanto maior fruto, quanto os Nossos se achem mais afastados da condição ou natureza daqueles homens que podem ser obstáculo para os demais; e posto caso que os descendentes da linhagem de cristãos novos tem causado à Companhia muitos obstáculos e danos, como vem demonstrando uma larga experiência (grifo nosso); por esta causa muitos pediram que se determinasse pela autoridade da presente Congregação, que daqui em diante, não seja admitido na Companhia nenhum que descenda da linhagem de judeus ou de mouros e que se algum deles por erro for admitido, o expulse assim que se averigue a existência de tal impedimento. Há satisfação, pois, a esta Congregação, 
determinar, como pelo presente Decreto seu o determina, que ninguém em absoluto pertencente a esta classe de homens descendentes da linhagem de judeus e de mouros, seja recebido daqui em diante, e que se algum por erro for admitido, seja expulso logo que se averigúe a existência de tal impedimento, em qualquer tempo que se descubra antes da profissão avisando de antemão ao Prepósito Geral e esperando previamente sua resposta. Disto deverão ser avisados todos os candidatos claramente antes de ser admitidos. Porque, inclusive quando a Companhia pela salvação universal das almas, deseja fazer-se toda a todos com o fim de ganhar para Cristo o máximo que possa, sem dúvida, não está obrigada a recrutar seus ministros de qualquer classe ou linhagem. Mais ainda, para a maior glória de Deus e para a mais perfeita consecução do fim que se propõe, é muito mais conveniente ter operários que sejam gratos a todas as demais nações estendidas pela Orbe e de quem possam servir-se com maior satisfação e confiança aquelas pessoas, cuja vontade, segundo que seja bem ou mal afeita para nós, influi tão decisivamente para que se abra ou se feche a porta ao serviço divino e salvação das almas, segundo disse nosso Padre Inácio de santa memória. Ademais, havendo surgido alguma dúvida sobre a força e eficácia deste Decreto, a saber, se o que nele se proíbe, deverá ser tido como um dos impedimentos essenciais que excluem absolutamente da Companhia ou, mais adequado, o considerar somente como impedimento não dispensável, depois de muitas razões alegadas em um e outro sentido, esta Congregação tem declarado e estatuído que o presente Decreto não tenha força de impedimento essencial, senão de não dispensável, de modo que nenhum superior, sem sequer o mesmo Padre Geral, possa dispensar dele e que daqui em diante se observe em dita forma íntegra e inviolável.”541.

${ }^{541}$ Institutum Societatis Iesu. Roma, 1860, vol. I, p. 257. Citado por Rey, Eusébio. Op. cit. p. 194. 
O motivo da exclusão dos cristãos novos ficou evidente no Decreto 52. Como demonstrava a experiência - rezava o Decreto - há muito tempo que os cristãos novos causavam problemas e prejudicavam a Companhia de Jesus. Apesar dela ter como missão a salvação universal das almas, ou seja, ganhar para Cristo o maior número possível de seguidores, ela não estava obrigada a recebê-los.

Seria muito mais conveniente, argumentaram os autores do Decreto 52, para a realização dos objetivos da Companhia, receber a quem agradasse a todas as nações e que servissem a todos sem causar desconfiança ou insatisfação. Portanto, o sucesso na tarefa de servir a Deus e salvar as almas dependia da reputação que os jesuítas alcançavam. Como os cristãos novos não eram aceitos pelas pessoas em geral, não havia outra solução senão excluí-los. Assim foi selada a sorte dos conversos no Decreto 52.

Estavam em jogo duas posições completamente antagônicas. Por um lado Pedro de Ribadeneira - representando os cristãos novos - justificando a presença e a permanência dos conversos na Companhia, por outro a Congregação Geral dizendo exatamente o contrário.

José de Acosta foi o único cristão novo presente à Congregação Geral. Apesar de estar sozinho, isolado politicamente, reprovou, com veemência, o Decreto 52. E o procurador de Castela, padre Árias, disse que duvidava muito da sua conveniência ${ }^{542}$.

Logo após a aprovação do Estatuto de Limpeza de Sangue alguns delegados tentaram amenizar o seu rigor. Sugeriram que o padre Geral recebesse os cristãos novos que ingressassem na Companhia de Jesus com boa fé, e que pudesse admitir, em raríssimos casos, candidatos com sangue judeu, na condição de serem de linhagem nobilíssima.

A Quinta Congregação Geral reprovou estas tentativas de atenuar o rigor do Decreto já aprovado. Nota-se que havia cristãos velhos capazes de tolerar os cristãos

\footnotetext{
${ }^{542}$ Ver Astrain, António. Op. cit., p. 593.
} 
novos, mas, naquele momento, os tolerantes eram uma minoria sem força política ${ }^{543}$. Os anti-semitas saíram vitoriosos. O Estatuto de Limpeza de Sangue da Companhia de Jesus estava aprovado sem limitação alguma. A vitória dos intolerantes foi completa $^{544}$.

${ }^{543}$ Ver Rey, Eusébio. Op. cit., pp. 194-95.

${ }^{544}$ Ver Rey, Eusébio, idem, p. 195. 


\section{CONSIDERAÇÕES FINAIS}

Apesar do contexto não ser favorável aos cristãos novos, eles foram inicialmente recebidos pela Companhia de Jesus sem causar, no primeiro momento, grandes problemas com os jesuítas cristãos velhos e tampouco com a sociedade como um todo. Muitos deles alcançaram papeis relevantes no processo de crescimento da Ordem, chegando alguns a se tornaram personagens centrais na construção de uma das mais importantes instituições da história da igreja católica romana, a Companhia de Jesus.

Não foi o sentimento altruísta que motivou o ingresso dos cristãos novos na Companhia, mas sim necessidades práticas da Ordem e a existência, mesmo que frágil, de uma conjuntura social, cultural, política e religiosa que ainda era capaz de tolerá-los como seus membros.

A decisão, de um lado, de aceitar cristãos novos e, do outro, a política adotada pela Companhia de Jesus de aliança com as elites econômicas, políticas, culturais e religiosas como meio de expansão da Ordem, resultou em conflitos que, com o transcorrer do tempo, tornaram-se insustentáveis.

As primeiras manifestações de insatisfação com a presença de cristãos novos na Companhia de Jesus surgiram nos primeiros regulamentos da Companhia. Estes regulamentos refletiram tanto a discriminação dos cristãos velhos jesuítas quanto a intolerância dos setores anti-semitas da sociedade, como por exemplo, a nobreza

ibérica e a catedral de Toledo. Foi devido às pressões dos anti-semitas que as Constituições aprovadas em 1558 exigiram que os postulantes declarassem sua ascendência.

O fundador da Companhia de Jesus, Inácio de Loyola, representou de forma eloquenteas contradições dos jesuítas em relação aos cristãos novos. Ao mesmo tempo em que ele foi o maior responsável pelo ingresso dos cristãos novos na Ordem, ele mesmo decidiu que a Companhia de Jesus não recebesse cristãos novos 
no arcebispado de Toledo e em toda Espanha, endossando assim o anti-semitismo do arcebispo Juan Martinez Siliceo.

Inácio de Loyola também foi um dos principais, senão o principal representante dos interesses inquisitoriais de D. João III e do inquisidor geral de Portugal, infante D. Henrique perante a Santa Sé.

Alguns dos expoentes da Companhia de Jesus reunidos em Roma, inclusive Inácio de Loyola, aceitaram a sugestão de D. João III para a Ordem ceder seus membros para serem inquisidores em Portugal.

A partir da terceira Congregação Geral a discriminação contra os cristãos novos se intensificou. As rivalidades entre cristãos novos e velhos no interior da Companhia se agravava rapidamente. Os cristãos velhos passaram a defender a adoção do Estatuto de Limpeza de Sangue; iniciaram uma campanha intensiva contra a concessão de cargos aos descendentes dos judeus. Muitos dos jesuítas cristãos velhos provinham de famílias nobres. A nobreza estava bem representada na Companhia de Jesus.

Ao mesmo tempo em que a Ordem prestava serviços ao Tribunal do Santo Ofício da Inquisição, os inquisidores revelavam-se insatisfeitos com a presença dos cristãos novos na Companhia. As pressões do Tribunal do Santo Ofíco se intenficaram e a Companhia acabou atendendo às exigências do Tribunal.

A intolerância da nobreza ibérica em relação aos cristãos novos cristãos novos jesuítas crescia à medida que a Companhia de Jesus tornava-se cada vez mais influente e poderosa. Os nobres portugueses e espanhóis reconheciam nos conversos grandes rivais dos seus filhos na carreira religiosa, inclusive como membro da nova Ordem, pois poucos anos após sua fundação a Companhia de Jesus já oferecia carreira promissora para quem nela ingressasse.

Ao mesmo tempo em que as facções da nobreza pressionavam a Companhia de Jesus para impedir o ingresso dos cristãos novos, as monarquias ibéricas adotavam a mesma política intolerante, apoiada pelas camadas populares. A discriminação contra os cristãos novos tornava-se cada vez maior. O Tribunal do 
Santo Ofício desempenhou um papel relevante neste processo de estigmatização dos descendentes de Judeus.

Com o transcorrer do tempo, diminuía o número de cristãos velhos favoráveis aos cristãos novos. Até mesmo na Itália, que antes os acolhia sem maiores resistências.

Houve um momento em que o próprio Vigário Geral da Companhia de Jesus, Cláudio Acquaviva, que inicialmente não discriminava os conversos, cedeu às pressões anti-semitas de seus companheiros jesuítas cristãos velhos, da nobreza, da Inquisição e da população em geral.

Foi desferido um último e definitivo golpe. Os cristãos novos jesuítas foram acusados pelos cristãos velhos da Companhia de escrever uma série de textos (os memoriais) que, entre outras coisas, criticavam a organização da Companhia da Companhia de Jesus.

Os cristãos novos não contavam mais com o apoio das primeiras gerações dos jesuítas. Um dos seus últimos representantes foi o padre Pedro de Ribadeneira. Sua defesa apaixonada dos portugueses e espanhóis de origem judaica ecoou como um grito desesperado, representando o fim de um espaço onde, durante cinquenta e três anos, os cristãos novos encontraram refúgio numa Península Ibérica que se tornou totalmente anti-judaica.

As pressões sóciais contra os cristãos novos jesuítas foram extremamente fortes. Os interesses dos inacianos cristãos velhos influíram de forma determinante sobre as decisão da Companhia de Jesus em não permitir a entrada de descendentes de judeus. Estigmatizados pela sociedade, discriminados dentro da própria instituição a qual tanto ajudaram a construir e a crescer, os cristãos novos viram-se finalmente vencidos.

A Companhia de Jesus não reconheceu os serviços relevantes prestados pelos conversos. Caso reconhecesse teria condições políticas para continuar a recebê-los. Esta afirmação se fundamenta, por exemplo, na nomeação para cardeal do jesuíta e cristão novo Francisco de Toledo, ocorrida no mesmo ano em que se realizou a V 
Congregação Geral e nos laços estreitos de amizade existentes entre Felipe II e o cristão novo José de Acosta, o qual teve o apoio do próprio Papa Clemente VIII.

É evidente que caso continuasse a aceitá-los a Companhia de Jesus teria um custo político talvez relativamente alto. Mas ela otpou por não assumir tais custos. Sua lógica em ralação à admissão dos cristãos novos era a seguinte: plenos benefícios e custos ou nulos ou mínimos.

Os cristãos novos não eram mais necessários. A Companhia de Jesus cresceu, tornou-se influente, poderosa e cobiçada. Parcela importante dos seus grandes “arquitetos” já podia ser dispensada. Já exixtiam substitutos suficientes e à altura para continuar a obra firmemente consolidada.

Foi esse o reconhecimento e a gratidão final que os cristãos novos receberam da Companhia de Jesus pelos significativos serviços a ela prestados. Essa foi a justiça e a recompensa que receberam por tudo que os descendentes dos judeus fizeram pela Ordem que amaram e à qual dedicaram suas vidas. 


\section{FONTES PRIMÁRIAS IMPRESSAS}

- Cartas, Informações, Fragmentos Históricos e Sermões do P. Joseph de Anchieta, S. J. (1554- 94). Rio de Janeiro, Civilização Brasileira, 1933.

- Cartas de San Ignacio de Loyola Fundador de la Compañía de Jesus. Tomo III. Monumenta Historica Societatis Iesu Madrid, IHS, Imprenta de la V. é Hijo de D. E. Aguado, Pontejos, 8, 1877.

- Constituições da Companhia de Jesus e Normas Complementares. São Paulo, Edições Loyola, 1997.

- Documenta Indica II (1550-53. Edidit Ioseph Wicki S. I. Romae, Apud “Monumenta Historica Soc. Iesu, 1950.

- Documenta Indica III 1553-57). Edidit Ioseph Wicki S. I. Romae, Apud “Monumenta Historica Soc. Iesu, 1954.

- Documenta Indica IV (1557-60). Edidit Ioseph Wicki S. I. Romae, Apud “Monumenta Historica Soc. Iesu, 1956.

- Documeta Indica V (1561-63). Edidit Ioseph Wicki S. I. Romae, Apud “Monumenta Historica Soc. Iesu, 1958.

- Documenta Indica VI. Edidit Ioseph Wicki S. I. Romae, Apud "Monumenta Historica Soc. Iesu,”. 1960.

- Documenta Indica VII. Edidit Ioseph Wicki S. I. Romae, Apud "Monumenta Historica Soc. Iesu, 1962.

- Documenta Indica VIII. Edidit Ioseph Wicki S. I. Romae, Apud "Monumenta Historica Soc. Iesu”, Institutum Historicum Societatis Iesu, 1964.

- Documenta Indica IX. Edidit Ioseph Wicki S. I. Romae, Apud "Monumenta Historica Soc. Iesu,” 1984.

- Documenta Indica X. Edidit Ioseph Wicki S. I. Romae, Apud "Monumenta Historica Soc. Iesu, Institutum Historicum Societatis Iesu, 1966.

- Documenta Indica XI. Edidit Ioseph Wicki S. I. Romae, Apud "Monumenta Historica Soc. Iesu, 1970. 
- Documenta Indica XII (1580-83). Edidit Ioseph Wicki S. I. Romae, Apud “Monumenta Historica Soc. Iesu”, 1972.

- Documenta Indica XIII (1583-85). Edidit Ioseph Wicki S. I. Romae, Apud “Monumenta Historica Soc. Iesu”, 1975.

- Documenta Indica XIV. Edited by Joseph Wicki S. J. and John Gomes S. J. Romae, 'Institutum Historicum Societatis Iesu,’ 1979.

- Documenta Indica XVI. Edited by Joseph Wicki S. J. and Jonh Gomes S. J. Roma, Institutum Historicum Societatis Iesu, 1984.

- Epistolae S. Francisco Xavierii. Aliaque Eius Scripta. Ediderunt G. Schurhammer S. I. et I. Wicki S. I. Tomus II (1549-52). Roma, Apud “Monumenta Historica Soc. IESU, 1945.

- Epistolae Mixtae, Tomo II, Madrid, 1899.

- Epistolae Mixtae. Tomus tertius (1553). Matriti, 1900.

- Epistolae Mixtae, Tomo IV. Madrid, 1900.

- Epistolae PP. Paschasii Broëti, Claudii Jaji, Joannis Codurii et Simonis Rodericii. Matriti, 1903.

- Loyola, Inácio de. Exercícios Espirituais. São Paulo, Edições Loyola, 2000.

- Monumenta Historica Brasiliae I (1538-53). Por respeito Serafim Leite S. I. Roma, Monumenta Historica Societatis Iesu, 1959.

- Monumenta Brasiliai II (1553 - 58). Por Serafim Leite S. I. Roma, Monumenta Historica Societatis Iesu,_1957.

- Monumenta Ignatiana, Série 1a, Tomo IX. Madrid, 1900.

- Monumenta Igantiana, Séries Prima, Epistolae et Instructiones. Tomus Primus. Matriti, 1903.

- Monumenta Ignaciana. Tomo IV. Madrid, 1906.

- Monumenta Ignatiana Ex Autographis Vel Ex Antiquiobus Exemplis Colleta Serie Prima - Sancti Ignatii de Loyola - Societatis Jesu Fundatores - Epistolae et Instructiones, Tomus Sextus. Matriti, 1907.

- Monumenta Ignatiana. Series I, T. V. Madrid, 1907. 
- Monumenta Ignagtiana, Series Prima, Epistolae et Instructiones, Tomus Octavus, Matriti, 1909.

- Monumenta Ignatiana, Série 1ª, Tomo XII. Madrid, 1911.

- Monumenta Ignatiana, Ex Autographis Vel Antiquioribus Exemplis Collecta. Series Tertia. Sancti Ignatii de Loyola. Constitutiones Societatis Jesu. Tomus Primus. Monumenta Constitutionum Praevia. Roma, 1934.

- Monumenta Ignatiana. Ex Autographis Vel Antiquioribus Exemplis Colecta. Series Terria. Sancti Ignatii de Loyola. Constitutiones Societatis Jesus. Tomus Secundus. Textus Hispanus. Roma, 1936.

- Monumenta Ignatiana. Séries Tertia, Constitutiones Societatis Jesu. Tomus Primus, Monumenta Constitutionum Praevia. Roma, 1934. Org. A. Codina. Constitutiones Anni 1541.

- Monumenta Ignatiana, Series Tertia, Sancti Inatii de Loyola, Constitutiones Societatis Jesu, Tomus Secundus, Textus Hispanus. Roma, !936, Examen Cum Declarationibus, Textus a, CA, 1546

- Monumenta Ignatiana, Series Tertia, Constitutiones et Regulae Societatis Iesu, Volumen 4, Regulae Societatis Iesu (1540-54). Edidit Dionysius Fernández Zapico S. I. Romae, 1948.

- Monumenta Peruana III (1581-85). Por Antonio de Egaña. Roma, Institutum Historicum Societatis Iesu, 1961.

- Monumenta Peruana V. Por Antonio de Egaña S. I. Roma, Institutum Historicum Societatis Iesu, 1970.

- Monumenta Peruana VII. Por Antônio Egaña S. I. e Enrique Fernandes S. I. Roma, Institutum Historicum Societatis Iesu, 1981.

- San Ignacio de Loyola. Obras Completas. IV Edição, Madrid, 1982.

- Lainii Monumenta. Epistolae et Acta. Patris Jacobi Lainii, Tomus Quartos (15581560). Matrit, 1915.

- Patris Petri de Ribadeneira. Societatis Jesu Sacerdotis. Confessione, Epistolae Aliaque Scripta Inedita. Tomus Secundus. Matrit. 1923. 
- Simonis Rodericii Monumenta. In Epistolae PP. Paschasii Broëti, Claudii Jaji, Joannis Codurii et Simonis Rodericii. Societatis Jesu. Matriti, 1903. 


\section{BIBLIOGRAFIA ESPECÍFICA}

- ALDEN, Dauril. The Making of an Enterprise. The Society of Jesus in Portugal, Its Empire, and Beyond (1540 - 1750). California, Stanford University Press, 1996.

- ASTRAIN, P. Antônio S. J. Santo Inácio de Loyola. Fundador da Companhia de Jesus (1491-1556). Porto, Biblioteca do Apostolado da Imprensa, 1927.

Historia de la Companía de Jesus en la Asistencia de

Espana. Tomo I (1540-56). Madrid, 2ª Edição, 1912.

Historia de la Compañía de Jesús en la Asistencia de

España. Tomo III, Mercuriano-Aquaviva, 1573-1615. Madrid, Razon y Fe, JHS, 1909.

- AZEVEDO, João Lúcio de. História dos Cristãos-Novos Portugueses. Lisboa, Clássica Editora, 1989.

- Os Jesuítas no Grão-Pará: suas missões e colonização. Coimbra, Imprensa da Universidade, 1930.

- BAIÃO, Antônio. A Inquisição em Goa. Tentativa de História da sua Origem, Estabelecimento, Evolução e Extinção. Vol. I. Lisboa, Academia das Ciências de BAIÃO, V. Antônio. Episódios Dramáticos da Inquisição Portuguesa. Porto, Edição da Renascença Portuguesa, 1919.

Episódios Dramáticos da Inquisição Portuguesa. Porto, Edição da

Renascença Portuguesa, 1919.

- BANGERT, W. História da Companhia de Jesus. Porto, Livraria A. I., 1972-1986, São Paulo, Edições Loyola, 1985.

- BETHENCOURT, Francisco. História das Inquisições. Portugal, Espanha e Itália. Séculos XV-XIX. São Paulo, Companhia das Letras, 2000. 
- COELHO, António Borges. "Tradição e Mudança na Política da Companhia de Jesus Face à Comunidade dos Cristãos-Novos.” In Revista de História. Porto, Centro de História da Universidade do Porto, Vol. X, 1999, pp. 87-94.

- CUNHA, Ana Cannas da. A Inquisição no Estado da Índia. Origens (1539-60). Estudos e Documentos. Lisboa, Arquivos Nacionais/Torre do Tombo, 1995.

- FABRE, Pierre-Antoine. La Conversion Infinie dês Conversos. Des « nouveauxchrétiens » dans la Compagnie de Jésus. Annales HSS, nº 4, juillet-août 1999

- FILHO. Spencer Custódio S.J. Os Exercícios Espirituais de Santo Inácio de Loyola. Um manual de estudo. São Paulo, Edições Loyola, 1994. das Reformas. Tomo III. Rio de Janeiro, Zahar Editores, 1984.

- FRANCO, António S. J. Ano Santo da Companhia de Jesus em Portugal. $1^{\text {a }}$ Edição. Porto, Biblioteca do “Apostolado da Imprensa”, s/d.

- FRANCO, António S, J. Imagem da Virtude em o Noviciado da Companhia de Jesus no Real Collegio de Jesus de Coimbra, na qual se Comtem as Vidas, e Virtudes de muytos Religiozos, que nesta Santa Caza foraõ Noviços. Offerecida A' Senhora da Victoria, Padroeira do mesmo Noviciado, pelo P. Antonio Franco da Companhia de Jesus. Segundo Tomo. Coimbra, no Real Collegio das Artes da Companhia de Jesus, Anno 1719.

- FRANCO, José Eduardo. O Mito dos Jesuítas. Em Portugal, no Brasil e no Oriente (Séculos XVI XX). Paris, Tese de Doutorado Defendida na École des Hautes Études en Sciences Socialies, 2004.

- FRANZEN, Beatriz Vasconcelos. Jesuítas Portugueses e Espanhóis no Sul do Brasil e Paraguai Coloniais. São Leopoldo, Editora Unisinos, 2003.

- HERCULANO, Alexandre. História da Origem e Estabelecimento da Inquisição em Portugal. Tomo I, VIII Edição. Lisboa, Livrarias Aillaud e Bertrand, s/d.

- ---------.-- Herculano, Alexandre. História da Origem e Estabelecimento da Inquisição em Portugal. Tomo III, 13ª edição, Amadora, Livraria Bertrand, s/d. 
- KAMEN, Henry. La Inquisición Española. Una revisión histórica. Barcelona, Editorial Crítica, 1999.

- KAYSERLING, Meyer. . História dos Judeus em Portugal. São Paulo, Livraria Pioneira Editora, 1971.

- LEITE, Serafim S. I. História da Companhia de Jesus no Brasil. Tomo II (Século XVI - A Obra). Lisboa, Livraria Portugália, Rio de Janeiro, Civilização Brasileira, 1938.

- --------------. Suma Histórica da Companhia de Jesus no Brasil (Assistência de Portugal) 1549 - 1760. Lisboa, Junta de Investigações do Ultramar, 1965.

- ------------. Monumenta Brasiliae. Roma, "Monumenta Histórica Societatis Iesu”, Vols. 1-5, 1956- 58, 1960 e 1968.

- MARQUES, João Francisco. Os Jesuítas, Confessores da Corte Portuguesa na Época Barroca (1550-1700). Porto, separata da Revista da Faculdade de Letras, II Série, Vol.XII, 1995.

- MEDINA, Francisco de Borja. San Ignacio y los Judios. In Anuario del Instituto Ignacio de Loyola, n. ${ }^{\circ}$ 4. San Sebastián, 1997.

- --------------. "Ignacio de Loyola y la Limpieza de Sangre”. In Ignacio y su Tiempo. Roma, Istituto Istórrico S. J, 1992.

- MARCCOCI, Giuseppe. Inquisição, Jesuítas e Cristãos-Novos em Portugal no Século XVI. Universidade de Coimbra, Revista da História das Ideias, vol. 25, 2004. - NOVALIN, José Luís Gonzales. La Inquisición y la Compañía de Jesús. In Antológica Annua, n. ${ }^{\circ}$ 37. Roma, Instituto Español de Historia Eclesiástica, 1990.

- NOVINSKY, Anita W. Cristãos Novos na Bahia. São Paulo, Perspectiva, 1972.

- ----------------. A Inquisição. São Paulo, Brasiliense, 1990.

- ---------------. Padre Antônio Vieira, A Inquisição e os Judeus. In Cadernos Cebrap, número 29, pp.172-181. 
- O’MALLEY, John W. Os Primeiros Jesuítas. São Leopoldo, Editora Unisinos, Bauru, Edusc, 2004.

- ORTIZ, Antonio Dominguez. Los Judeosconversos en la España Moderna. Madrid, Editorial Mapfre, 1993.

- PLAZAOLA, Juan (Ed.). "Ignacio de Loyola y su Tiempo”. Congreso Internacional de Historia, 9 - 13 de septiembre de 1991. Bilbao, Ediciones Mensajero, 1992.

- POLIAKOV, Léon. De Maomé aos Marranos. São Paulo, Perspectiva, 1996.

- QUEVEVO, Júlio. Guerreiros e Jesuítas na Utopia do Prata. Bauru, Edusc, 2000.

- REY, Eusébio S. J. "San Ignacio de Loyola y el Problema de los Cristianos Nuevos”. Madrid, Razón y Fe, Revista Mensual Hispanoamericana, Publicada por Padres de la Compañía de Jesús, núms. 696-701, tomo 153, 1956.

- REITES, W. James, S. J. "Ignatius of Loyola and the Jews”. In Studies in the Spirituality of Jesuits. Vol. XIII, N. ${ }^{\circ}$ 4, September, 1981.

- REVAH, I. S. «Les Origines Juives de Quelques Jésuites Hispano-Portugais du XVI Siècle. » In Etudes Ibériques et Latino-Américaines : IV Congrès des Hispanistes Français. Paris, Presses Universitaires de France, 1968.

- RODRIGUES, Francisco S. J. História da Companhia de Jesus na Assistência de Portugal. Tomo I, Vol. II. Porto, Apostolado da Imprensa, Empresa Editora, 1931.

- ---------------------------. História da Companhia de Jesus na Assistência de Portugal. Tomo II, Vol. I. Porto, Livraria Apostolado da Imprensa, 1938.

- -----------------------------. A Companhia de Jesus em Portugal e nas Missões. Esboço Histórico - Superiores - Colégios - 1540-1934. Segunda Edição. Porto, Edições do Apostolado da Imprensa, 1935.

- --------- A Formação Intelectual do Jesuíta. Leis e Fatos. Porto, Livraria Magalhães e Moniz Editora, 1917.

- SALVADOR, José Gonçalves. Cristãos-Novos, Jesuítas e Inquisição. Aspectos de sua atuação nas capitanias do Sul, 1530-1680. São Paulo, Livraria Pioneira Editora. Editora da Universidade de São Paulo, 1969. 
- SARAIVA, António José. Inquisição e Cristãos-Novos. Lisboa, Editorial Estampa, 1984

- SICROFF, Albert. Los Estatutos de Limpieza de Sangre. Controversias entre los siglos XV e XVII. Madrid, Tauros, 1981.

- TAVARES, Célia Cristina da Silva. A Cristandade Insular: Jesuítas e Inquisidores em Goa (1540 - 1682). Tese Defendida em 2002 na Universidade Federal Fluminense.

- TELLEZ, Balthazar S. J. Chronica da Companhia de Iesu na Província de Portugal e do que Fizeram, nas Conquistas d'este Reyno, os Religiosos, que na mesma Província entraram, nos annos em que viveo S. Ignacio de Loyola nosso Fundador. Pelo P. M. Balthazar Tellez, da mesma Companhia, natural da cidade de Lisboa, e nella Lente de Prima de Theologia. Primeira Parte na Qual se Contem os Princípios d'esta Província. No Tempo em que a fundou e governou o P. M. Simam Rodrigues, Com sua santa vida e morte. Em Lisboa, Anno do Senhor MDCXXXXV.

- VASCONCELLOS, Simão de. Chronica da Companhia de Jesu do Estado do Brasil e do que Obraram seus Filhos N'Esta Parte do Novo Mundo. Em que se Trata da Entrada da Companhia de Jesu nas Partes do Brasil, dos Fundamentos que N'Ellas Lançaram e Continuaram seus Religiosos, e Algumas Noticias Antecedentes, Curiosas e Necessárias das Cousas D'Aquelle Estado pelo Padre Simão Rodrigues da Mesma Companhia. Tomo Primeiro (e Único). Segunda Edição Correcta e Augmentada. Vol. I, Lisboa, em Casa do Editor A. J. Fernandes Lopes, MDCCCLXV.

- WRIGHT, Jonathan. Os Jesuítas. Missões, Mitos e Histórias. Lisboa, Quetzal Editores, 2005. 
- ALMEIDA, João Ferreira de (tradução). A Bíblia de Promessas. Vila Hamburguesa, King's Cross Publicações, Rio de Janeiro, Junta de Educação Religiosa e Publicações. Imprensa Bíblica Brasileira. 3ª Edição, 2005.

- BARRET-DUCROCQ, Françoise. A Intolerância: Foro Internacional sobre a Intolerância. Rio de Janeiro, Bertrand Brasil, 2000.

- BOSSY, John. A Cristandade no Ocidente (1400-1700). Lisboa, Edições 70, 1990.

- BOURDIEU, Pierre. A Economia das Trocas Simbólicas. São Paulo, Perspectiva, 1992.

- BOXER, Charles Ralph. O Império Colonial Português (1415-1825). São Paulo, Edições 70, 1977.

- BURCKHARDT, Jacob. A Cultura do Renascimento na Itália: um ensaio. Brasília, Editora da Universidade de Brasília, 1991.

- CHAUNU, Pierre. O Tempo das Reformas (1250 - 1550). História Religiosa e Sistema de Civiliazação. II. A Reforma Protestante. Lisboa, Edições 70, 1993.

- CORTESÃO, Jaime. História da Expansão Portuguesa. Lisboa, Imprensa Nacional - Casa da Moeda, 1993.

. O Humanismo Universalista dos Portugueses: A Síntese Histórica Literária. Lisboa, Portugalia Editora, 1965.

- ELIADE, Mircea. O Sagrado e o Profano: a essência das religiões. Lisboa, Edição “Livros do Brasil”, 19--.

- -------------. História das Crenças e da Idéias Religiosas. De Maomé à Idade das Reformas. Tomo III. Rio de Janeiro, Zahar Editores, 1984.

- FLUSSER, David. Jesus. São Paulo, Editora Perspectiva, 2002.

- HISCH, Elisabeth Feist. Damião de Góis. Fundação Calouste Gulbenkian, 1987.

- HOONAERT, Eduardo. A Igreja no Brasil-Colônia: 1550-1800. São Paulo, Editora Brasiliense, 1982. 
- HUMBOLDT, Wilhelm von. Escritos de Filosofía de la Historia. Madrid, Editorial Tecnos, 1997.

- LACOMBE, Américo Jacobina. “A Igreja no Brasil Colonial”. In História Geral da Civilização Brasileira, tomo I, A Época Colonial, II volume: Administração, Economia, Sociedade. (Direção: Sérgio Buarque de Holanda e Pedro Moacyr Campos). São Paulo, Difel, 1960.

- MATTOSO, José (Direção). História de Portugal. Terceiro Volume. No Alvorecer da Modernidade (1480 - 1620). Lisboa, Editorial Estampa, 1993.

- NEMÉSIO, Vitorino. Companhia de Jesus e o Plano Português do Brasil. Lisboa, Secretaria da Informação e Turismo, 1971.

- OMEGNA, Nelson. A Diabolização dos Judeus: "martírio e presença dos sefardins no Brasil colonial”. Rio de Janeiro, Distribuidora Record, 1969.

- PICHARDIE, Jean Paul e CAPET, Antoine (Orgs.). La Naissance de L’Idée de Tolerance (1660-1689). Universidade de Ruen, C.É.L.C.L.A., Janeiro 1999.

- SARAIVA, António José. História da Cultura em Portugal. Vol. 1, Renascimento e Contra-Reforma. Lisboa, Gradiva, 2000.

- SARTRE, Jean-Paul. Questão de Método. São Paulo, Difusão Europeia do Livro, $2^{\mathrm{a}}$ Edição, 1967.

- SERRÃO, Joaquim Veríssimo. História de Portugal. Volume IV. Governo dos Reis Espanhóis (1580 - 1640). 2ª Edição. Lisboa, Editorial Verbo, 1990.

- Veyne, Paul. Como se Escreve a História. Lisboa, Edições 70, 1983.

- ZANADÍM. Historia dos Portugueses no Malabar. Lisboa, Imprensa Nacional, 1898.

- WEBER, Max. Sobre a Teoria das Ciênicas Sociais. Lisboa, Editorial Presença, 1974.

- WIZNITZER, Arnold. Os Judeus no Brasil Colonial. São Paulo, Pioneira, Edusp, 1966. 


\section{DICIONÁRIOS E ENCICLOPÉDIAS}

- Tratado de Todos os Vice-Reis e Governadores da Índia. Lisboa, Editorial Enciclopédia, 1962.

- Enciclopédia Verbo Luso-Brasileira de Cultura. Edição Século XXI, 13. Lisboa, São Paulo, Editorial Verbo, 2000. 
- O’Neill, Charles E., S. I. e Domínguez, Joaquín M. ${ }^{a}$, S. I. (Directores). Diccionario Histórico de la Compañía de Jesus. Biográfico-Temático, Vols. I, II e IV. Roma, Institutum Historicum, S. I. 2001 e Madrid, Universidade Pontifícia Comillas, 2001. - Sommervogel, Carlos. Bibliotheque de la Compagnie de Jesus. Bruxelles, Vol. 8, 1898.

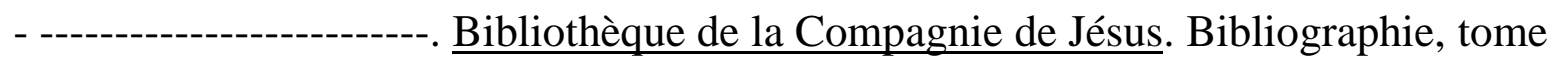
V. Bruxelles, Oscar Schepens, Paris, Alphonse Picard, MDCCCXCIV. 